\title{
The Philosophy of Desire in the Buddhist Pali Canon
}

\section{David Webster}




\section{THE PHILOSOPHY OF DESIRE IN THE BUDDHIST PALI CANON}

David Webster explores the notion of desire as found in the Buddhist Pali Canon. Beginning by addressing the idea of a 'paradox of desire', whereby we must desire to end desire, the varieties of desire that are articulated in the Pali texts are examined. A range of views of desire as found in Western thought are presented as well as Hindu and Jain approaches. An exploration of the concept of ditthi (view or opinion) is also provided, exploring the way in which 'holding views' can be seen as analogous to the process of desiring. Other subjects investigated include the mind-body relationship, the range of Pali terms for desire and desire's positive spiritual value. A comparative exploration of the various approaches completes the work.

David Webster is lecturer in Religious Studies at the University of Gloucestershire. 


\section{ROUTLEDGECURZON CRITICAL STUDIES IN BUDDHISM \\ General Editors:}

Charles S. Prebish and Damien Keown

RoutledgeCurzon Critical Studies in Buddhism is a comprehensive study of the Buddhist tradition. The series explores this complex and extensive tradition from a variety of perspectives, using a range of different methodologies.

The series is diverse in its focus, including historical studies, textual translations and commentaries, sociological investigations, bibliographic studies, and considerations of religious practice as an expression of Buddhism's integral religiosity. It also presents materials on modern intellectual historical studies, including the role of Buddhist thought and scholarship in a contemporary, critical context and in the light of current social issues. The series is expansive and imaginative in scope, spanning more than two and a half millennia of Buddhist history. It is receptive to all research works that inform and advance our knowledge and understanding of the Buddhist tradition.

\section{A SURVEY OF VINAYA LITERATURE Charles S. Prebish}

THE REFLEXIVE NATURE OF AWARENESS

Paul Williams

ALTRUISM AND REALITY Paul Williams

BUDDHISM AND HUMAN RIGHTS

Edited by Damien Keown,

Charles Prebish, Wayne Husted

\section{WOMEN IN THE FOOTSTEPS OF THE BUDDHA}

Kathryn R. Blackstone

THE RESONANCE OF EMPTINESS

Gay Watson

AMERICAN BUDDHISM

Edited by Duncan Ryuken Williams and

Christopher Queen

\section{IMAGING WISDOM \\ Jacob N. Kinnard}

PAIN AND ITS ENDING

Carol S. Anderson

EMPTINESS APPRAISED

David F. Burton

THE SOUND OF LIBERATING TRUTH Edited by Sallie B. King and Paul O. Ingram

BUDDHIST THEOLOGY

Edited by Roger R. Jackson and

John J. Makransky

THE GLORIOUS DEEDS OF PURNA Joel Tatelman

EARLY BUDDHISM - A NEW

APPROACH

Sue Hamilton 
CONTEMPORARY BUDDHIST ETHICS

Edited by Damien Keown

INNOVATIVE BUDDHIST WOMEN

Edited by Karma Lekshe Tsomo

TEACHING BUDDHISM IN THE WEST

Edited by V.S. Hori, R.P. Hayes and

J.M. Shields

EMPTY VISION

David L. McMahan

SELF, REALITY AND REASON

IN TIBETAN PHILOSOPHY

Thupten Jinpa

IN DEFENSE OF DHARMA

Tessa J. Bartholomeusz

BUDDHIST PHENOMENOLOGY

Dan Lusthaus

RELIGIOUS MOTIVATION AND THE

ORIGINS OF BUDDHISM

Torkel Brekke

DEVELOPMENTS IN

AUSTRALIAN BUDDHISM

Michelle Spuler
ZEN WAR STORIES

Brian Victoria

THE BUDDHIST

UNCONSCIOUS

William S. Waldron

INDIAN BUDDHIST THEORIES

OF PERSONS

James Duerlinger

ACTION DHARMA

Edited by Christopher Queen, Charles

Prebish and Damien Keown

TIBETAN AND ZEN BUDDHISM IN BRITAIN

David N. Kay

THE CONCEPT OF THE BUDDHA Guang Xing

THE PHILOSOPHY OF DESIRE

IN THE BUDDHIST

PALI CANON

David Webster

THE NOTION OF DITTHI IN

THERAVADA BUDDHISM

Paul Fuller 
The following titles are published in association with the Oxford Centre for Buddhist Studies

$$
\text { 2. Oxford Centre for Buddhist Studies }
$$

The Oxford Centre for Buddhist Studies conducts and promotes rigorous teaching and research into all forms of the Buddhist tradition.

\section{EARLY BUDDHIST METAPHYSICS \\ Noa Ronkin}




\section{THE PHILOSOPHY OF DESIRE IN THE BUDDHIST PALI CANON}

\section{David Webster}

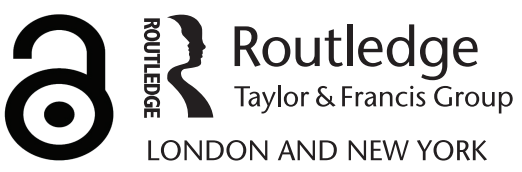




\section{First published 2005 by Routledge \\ Published 2017 by Routledge}

2 Park Square, Milton Park, Abingdon, Oxon OX14 4RN 711 Third Avenue, New York, NY 10017, USA

Routledge is an imprint of the Taylor \& Francis Group, an informa business

Copyright (C) 2005 David Webster

Typeset in Times New Roman by

Newgen Imaging Systems (P) Ltd, Chennai, India

The Open Access version of this book, available at www.tandfebooks.com, has been made available under a

Creative Commons Attribution-Non Commercial-No Derivatives 4.0 license.

British Library Cataloguing in Publication Data

A catalogue record for this book is available from the British Library

Library of Congress Cataloging in Publication Data A catalog record for this book has been requested

ISBN13: 978-0-415-34652-8 (hbk)

ISBN13: 978-0-415-60000-2 (pbk) 
This book is dedicated to the memory of Diana Trainor, 1941-2002.

\author{
Angels \\ (to the memory of Diana) \\ History will record \\ that among us \\ walked certain angels \\ whose wings \\ wove patterns \\ of laughter \\ in the air \\ whose songs \\ salted \\ the humdrum \\ of our days \\ whose dance \\ lifted us \\ made our \\ lives lighter \\ History will record \\ too late \\ our indifference \\ to their difference: \\ all these strange \\ odd, eccentric \\ ethereal angels \\ who once walked among us... \\ Cecil Rajendra
}





\section{CONTENTS}

Acknowledgements xii

List of abbreviations $\quad$ xiii

Introduction: desire, morality and approaches

Introduction: you cannot always get what you want 1

The paradox of desire 2

But what is 'desire'? 4

Desire as problematic 7

Scope of this study 8

Approach and method 1: chapter outlines 8

Approach and method 2: key concepts 12

Approach and method 3: sources and textual issues 16

Conclusion: aspirations 16

1 Desire in Western thought

Introduction 18

An ancient lack 22

A striving after wind: Ecclesiastes and

Judaeo-Christian thought 25

Shakespeare: love, death and desire 27

Surveying desire: Hobbes, Spinoza, Locke and Hume 29

Schopenhauer: the will and the world 30

Nietzsche to Deleuze: desire, will and power 35

Hegel and Butler 42

Sartre-desire and nothingness 43

The purification of desire: Theosophy 44

Mind-made desires 45

Conclusion 46 
2 Desire in non-Buddhist Indian religion

Introduction 49

Desire in the Veda Samhitās 52

Desire as the enemy of the spiritual 57

Desire in the Bhagavad Gìtā 70

Sex, love and desire: the Kāma Sūtra 76

Jainism and desire: the calm fight against karma 81

Conclusion 86

\section{Buddhism and desire: the varieties of desire}

Introduction 90

Which Buddhism? 91

The redirection of desire 91

Desire and nibbāna 94

Desire and the Buddha 97

The varieties of desire 98

The three roots of unskilful action (akusalamūla) 100

Terms from the lobha list at Vibhanga 361-2 105

Terms not in the lobha list at Vibhanga 361-2 112

Some minor terms illustrative of desire 127

Taṇhā: craving and desire 129

Conclusion: landscapes of desire 140

4 Buddhism and desire: the dynamics of desire

Introduction 143

The nature of paticca-samuppāda 146

Desire and paticca-samuppāda 151

The mind-body relationship 158

The status of views: a structural analogy? 165

The problem with views 168

No-view or right-view? 171

Sammā-ditthi - the nature of 'Right-View' 173

A paradox of views? 179

Desire and views: craving and ignorance 180

Reason and desire revisited 182

Conclusion 184 
5 Conclusion: desire and the transformation of living

Introduction 187

Western perspectives 188

Brahmanic views: desire and ontological necessity 190

Buddhism and desire: an emerging position? 191

Roads to freedom 192

Desire and reason: challenging a bi-polar distinction 193

Desire and 'lack' 194

Desire and goodness 198

Desire and death: seeking the end of the world? 199

Desire, passion and love 200

Desire and contingency: change and craving 202

Desire and power: the creative craver 203

Desire beyond the person: cosmic desire 204

Lust for life: desire and skilful living 204

Glossary

Notes

Bibliography

Index 


\section{ACKNOWLEDGEMENTS}

I would like to acknowledge the huge and patient efforts made by Peter Harvey, Professor of Buddhist Studies at the University of Sunderland, to support me in the production of my $\mathrm{PhD}$ thesis, which formed the basis for this book. His assistance has always been prompt, useful and thought-provoking. Dr Dermot Killingley, as ever, was helpful and worryingly encyclopaedic in his knowledge of Hinduism and Sanskrit.

I would also like to thank my wife, Anna, for the shouldering of numerous burdens - domestic, financial and emotional - that the presence of this book in our home has placed on her over the last five years. Our children, Holly and Jack, have accepted my distractedness and grumpiness during this project with a cheery stoicism for which I am more grateful than I might appear.

A number of people have had a less direct influence on the content of the bookbut their friendship and support has sustained me over the aeons it seems to have taken to produce it. With this in mind, my parents, Jim Brewster, Dr Paul Fuller, Matthew Green, Ted Haynes, Richard McMahon (and his Dionysian entourage), Ivan Bergquist and my Bristol quiz night/book group associates (Mike, Noel and Julian) should all consider themselves duly thanked.

Thanks, also, to Cecil Rajendra for permission to reproduce the poem 'Angels' in the dedication.

I also wish to acknowledge the assistance of the Theology and Religious Studies staff at the University of Gloucestershire, particularly Professor Melissa Raphael and Dr Peter Scott, who have provided support during the last two years of this project, besides listening patiently to my complaints and doubts. 


\section{ABBREVIATIONS}

Works detailed here are not listed in the bibliography at the end of the book.

\section{Pali texts}

Note: Unless otherwise indicated, references are to Pali Text Society edition volume and page numbers. Pali text cited in the book is from the CSCD version which was checked against the PTS edition. Any discrepancies between the CSCD and PTS versions of the text are noted in the book.

A Añguttara Nikāya

CSCD Chațha Sañgāyana CD-ROM, Version 3. The Pali Canon on CD-ROM. Vipassana Research Institute, Dhammagiri, India. www.vri.dhamma.org

D Dìgha Nikāya

Dhp Dhammapada

Dhs Dhammasangani

It Itivuttaka; It. references are to sutta number

Khp Khuddakapātha

M Majjhima Nikāya

Mil Milindapañha

Nett Nettipakarana

Nidd Mahāniddesa

Patis Patisambhidāmagga

Pet Petakopadesa

S Samyutta Nikāya

Sn Sutta-Nipāta; Note: Sutta-Nipāta references are to paragraph number, rather than volume and page number

Ud Udāna

Vibh Vibhanga

Vin Vinaya Pitaka

Vism Visudhimagga 


\section{Translations}

CDB The Connected Discourses of the Buddha. Two Volumes. Bodhi, Bhikkhu (Trans.), Wisdom Publications, Massachusetts, 2000. [A translation of the Samyutta Nikāya.]

DP The Dhammapada. Narada, Thera (Trans.), Corporate Body of the Buddha Educational Foundation, Taiwan, 4th edition, 1993.

LDB The Long Discourses of the Buddha. Walshe, Maurice (Trans.), Wisdom Publications, Massachusetts, 1995. [A translation of the Dìgha Nikāya.]

MLD The Middle Length Discourses of the Buddha. Nānnamoli, Bhikkhu and Bodhi, Bhikkhu (Trans.), Wisdom Publications, Massachusetts, 1995. [A translation of the Majjhima Nikāya.]

NDB Numerical Discourses of the Buddha: An Anthology of Suttas from the Anguttara Nikāya. Thera, Nyanaponika and Bodhi, Bhikkhu (Trans.), AltaMira Press, Maryland, 1999.

Pịt The Pițaka Disclosure. Nāṇamoli, Bhikkhu (Trans.), Pali Text Society, Oxford, 1979. [A translation of the Petakopadesa.]

PoP The Path of Purification. Ñānamoli, Bhikkhu (Trans.), Buddhist Publication Society, Kandy, 1991. [A translation of the Visudhimagga.]

QKM The Questions of King Milinda. Two Volumes. Davids, T. W. Rhys (Trans.), Motilal Banarsidass, Delhi, 1965. [A translation of the Milindapañha.]

SNip The Sutta-Nipāta. Saddhatissa, H. (Trans.), Curzon Press, Surrey, 1994.

TBA The Book of Analysis. Thittila, Pathamakyaw Ashin (Trans.), Pali Text Society, Oxford, 1995. [A translation of the Vibhanga.]

TPD The Path of Discrimination. Ñānamoli, Bhikkhu (Trans.), Pali Text Society, Oxford, 1997. [A translation of the Patisambhidāmagga.]

Ud-It The Udāna \& The Itivuttaka. Ireland, John (Trans.), Buddhist Publication Society, Kandy, 1997.

\section{Dictionaries and reference works}

PED Pali-English Dictionary. Davids, T. W. Rhys and Stede, William (Eds), Pali Text Society, Oxford, 1995.

ADP A Dictionary of Pali. Vol. I, A-Kh. Cone, Margaret, Pali Text Society, Oxford, 2001.

SED Sanskrit-English Dictionary. Monier-Williams, M. Motilal Banarsidass Publishers, Delhi, 1963. Note: In citations from the SED, slightly different diacritical marks are given, in line with the usage of the SED. This is rare, and fairly obvious, but worthy of note here.

EPD English-Pali Dictionary. Buddhadatta, Mahāthera A. P. Pali Text Society, Oxford, 1995. 
ABBREVIATIONS

\section{Other abbreviations}

WBR Western Buddhist Review. Available at www.westernbuddhistreview.com PTS Pali Text Society

JBE Journal of Buddhist Ethics (on-line journal). Available at http:// jbe.gold.ac.uk/

JPTS Journal of the Pali Text Society 



\title{
INTRODUCTION
}

\author{
Desire, morality and approaches
}

\begin{abstract}
All the toil of man is for his mouth, yet his appetite is not satisfied. For what advantage has the wise man over the fool? And what does the poor man have who knows how to conduct himself before the living? Better is the sight of the eyes than the wandering of desire; this also is vanity and a striving after wind. ${ }^{1}$
\end{abstract}

\section{Introduction: you cannot always get what you want}

Why begin a book on, primarily, Buddhism with a quote from the Bible? While Buddhism, as found in the Pali Canon, is my prime interest, I wish to state from the outset that my horizons here are broad. I will offer the rationale for this shortly, but let me make clear that what I am interested in here is desire. The Buddhist material is here because I have come to the view that it offers one of the best ways of moving towards an understanding of desire. Anything else that I have felt may do the same has therefore come into the orbit of my concerns.

But why 'desire'? I believe Buddhist thought - as found in the Pali Canon - offers a profundity of insight on this topic. Further to this, it is a concept we all, on some level, have daily familiarity with; while, at the same time, often giving it little or no sustained attention or reflection. Desire is both familiar and strange to us.

Buddhism offers a model of desire that is distinct from, but finds echoes in, Western philosophy (and to an extent psychology). It also is related, in various ways, to the Brahmanic traditions which existed prior to, alongside, and beyond the composition of the Pali Canon. The texts of early Buddhism offer us a way to execute radical interventions in the mechanics of our desiring. These interventions, via a self-initiated transformation of consciousness, can lead us, it is claimed, to live less harmful and more satisfying lives. Our lives can become such that our interaction with sense-objects is not invariably tainted by an impossible and damaging chase after mind-constructed ideals of permanence and substantiality.

In this introduction, I set out the concerns that I shall follow up throughout the book, and I have also felt it necessary to address a small number of themes, such as the translation of kusala as 'skilful', and the problems of addressing particularly 'spiritual'2 topics in language. 


\section{The paradox of desire}

It is an oversimplification of the Buddhist position to assume that it seeks an end of all desire. Such a view, however, is not uncommon. ${ }^{3}$

Many see desire in Buddhism as a single thing - not seeing the subtle range of types of wanting which are at play in the texts (and Buddhist practice). It is worth keeping this in mind when we consider the notion of a 'paradox of desire':

If I desire to cease desiring then I have not ceased all desire after all; I have merely replaced one species of desiring by another. The paradox of desire points to the practical contradiction or frustration involved in the desire to stop all desiring and states simply that those who desire to stop all desiring will never be successful. ${ }^{4}$

The piece from which I take this quote, and the set of articles in the subsequent issue of Philosophy East \& West that replied to it, were the starting point for my initial thoughts about the nature and status of desire in Buddhism. In the end I have come to the conclusion that these articles are, to a large extent, undermined by a misconceived view of the actual Buddhist position, but I will come to that shortly.

Initially I want to explain why this topic piqued my interest. In my student days studying Buddhism, I was aware of a general negative attitude to desire in Buddhism. Or so I thought. What I was actually cognisant of was a description of Buddhism as having such an attitude in secondary Western literature on Buddhism. Then, when I came to consider the topic for this present study, I began with an examination of the Four Noble Truths.

In reading around this topic, I became preoccupied with the second truth - that of craving (tanha $)$ as the basis of suffering $(d u k k h a)$. It soon became clear that there was a lot more to this topic than I had realised. This drew me to the Philosophy East \& West articles, and in the end to the production of this book.

To return to this notion of a paradox of desire, it is most easily seen in the sense of 'if I desire to end desire, I can never do so'. A. L. Herman's approach, in the piece cited above, is to contrast the desire for desirelessness with the notion of 'letting-go'. He draws on his reading of Mādhyamika Buddhism to claim that the realisation that desire can never take us beyond desire, is the basis for achieving that very goal:

That is to say, seeing that there is no way out of the paradox of desire, understanding that, as Mādhyamika Buddhism puts it, there is no way to nirvāna, no goal to be desired or achieved, then one 'lets go' of the way and the goal. And that 'letting go' leads to, or is, nirvāṇa. ${ }^{5}$

There are numerous things here that deserve comment. First, Herman goes beyond the type of Buddhism that I am interested in here, so I make no assessment of the accuracy of his portrayal of Mādhyamika thought. 
Second, as I discuss in Chapter 3, there do seem to be types of desiring that Buddhism does not condemn as unskilful (akusala - this term is discussed later in this Introduction). The assessment of desire in his piece is too straightforward - there is little sense of qualitative distinctions between types of desire.

Third, does he not fail within even his own terms of reference? How do we get to 'letting go'? Do we have to desire this letting-go in order to achieve it - or is this is as doomed as desiring nibbāna? He does offer a graduated path to the letting go, the key stage of which is the realisation of the paradox of desire. He sees Zen Buddhism as the final culmination of this trend - but I am not sure this is accurate. Further, the whole approach is based, on my reading, of a rejection of the Canonical injunctions regarding desire in general, and tanh $\bar{a}$ in particular. If Buddhism consists of something other than the overcoming of at least certain types of desire, why do we find so much of the tradition recommending that we encounter and overcome our desirous nature?

In response to Herman's piece, Wayne Alt argued that there was no paradox as the desire to end desire evaporated once successful: hence leaving us with no desire, by means of desiring this state:

Suppose I desire ${ }^{6}$ to eliminate desire2. If I satisfy desire1, that is, if I actually manage to eliminate desire2, then desire 1 will thereby be eliminated. For the satisfaction of any desire is tantamount to its elimination. So it appears that desire1, like any other desire, can be eliminated after all. Someone might reply that desire2 cannot be eliminated, and hence desire1 can never be satisfied. But it could not be argued, as Herman suggests, that desire 2 cannot be eliminated because desire 1 cannot be eliminated. That would simply beg the question. Hence, we are led back to the central question of this article: Why would it be paradoxical or otherwise logically absurd to suppose that human desire can be completely eliminated?

Is this any more satisfactory than Herman's account? Possibly, but the problem here is that the desires here seem to be distinguished only by the nature of their object. If so, is not desire 1 - once initiated - then also a component of desire2? There is still lacking a clear understanding of what desire $i s$. Alt partly concedes this, and closes with the words:

Perhaps in the future someone will attempt to clarify the concept of 'desire'. This would be an interesting philosophical project and an obvious contribution to Buddhist studies. ${ }^{8}$

I am not at all sure whether I have fulfilled his remit here, but it is clear that his view is based on a very simplistic understanding of the nature of desire. In a brief response to Wayne Alt, John Visvader - while in general agreement with Alt's claim that desire can lead to the end of desire - wishes to maintain 
the existence of a paradox:

It is naïve to think that my final desire to give up desires will just disappear when I have gotten rid of the other desires, for from the Buddhist point of view I have really not gotten anywhere by merely eliminating particular desires if I still have the desiring mind, that is, the mind of ignorance which has been expressing itself the whole time in the desire to desire to give up desires. $^{9}$

Visvader here sees something underlying individual desires - the desiring mind. This could be taken as indicating some notion of a diffuse form of desire that lies beneath its individual manifestations. This idea is one we shall see much more of. He sees paradox as less problematic though - seeing it, in line with his preference for a Zen-like approach - and possibly useful for helping to 'pry the student out of the desiring mind'. ${ }^{10}$ Herman wrote a reply to these responses, and in it moves some way to recognising some of the issues that form part of this study when he claims: "The desire to end desire is of a different order of desiring, and it leads to no cessation of desire as the Buddhists themselves have been at some pains to point out." ${ }^{11}$ The first part of this comment is useful and interesting - though it is not as clear what he means by the second portion, and he does not elaborate. In the end, this series of articles and responses ends with Herman when he states: 'I agree with Alt when he suggests that the attempt to clarify the concept of desire (and desirelessness) would make an interesting philosophical project." ${ }^{12}$ I mention this not as a rationale for this volume, but rather as it seems like an admission of defeat. It seems to have become clear to the participants in this debate that a much more detailed examination of the Buddhist understanding of desire is needed.

In this project I do not base the study on this notion of paradox. To do so would be to begin with a preconception: that such a thing exists. To have based it around deciding whether or not there was such a paradox also seems limiting; for I wish here to examine desire itself, not a self-referential form of it alone. The idea of a paradox was an important spur to my examinations, but does not dominate the thrust of my investigations.

\section{But what is 'desire'?}

Now we come to the consideration of definitions. I do not here, however, offer a definition of desire in a Buddhist context. In the English language the word 'desire' is one with a broad range of senses, if not meanings. Mrs Rhys Davids notes, when looking at Buddhism in translation:

a comparison of the translations made by such scholars as Burnouf, Foucaux, Max Muller, Fausboll, Oldenberg, and Warren with the originals, discloses the striking fact that the one English word 'desire' is made to do duty for no less than seventeen Pali words. ${ }^{13}$ 
In Chapter 3, I offer definitions in a Buddhist context. Here I wish to address some general consideration of the nature of desire. I also speculate as to why desire might be considered as problematic.

One issue which crops up at a number of points is the relation of 'will' and 'desire'. This has particular relevance to some of the material in the first chapter, particularly where Nietzsche's 'Will-to-power' and Schopenhauer's idea of the Will are invoked. It would be all too easy to conflate the two, but a distinction does need sustaining.

'Will' can be seen as 'intention', the mental occurrence that leads us into action. Willed action is intentional, rather than accidental, action. Now, not all desires lead to action, but this is not a major concern, as our will - as intention is something we often also fail to fulfil. Intentions are often abandoned, or even restrained. So, in what does the difference between the two consist?

I would claim, and seek to maintain this usage in what follows, that most acts of willing can be seen as the consequences of desire. The desire, and the intending or willing, are not the same, but the willing derives from a desire. ${ }^{14}$ In this way then, the will, usually, is an expression of desiring. For example, we may have a fairly constant desire that is only intermittently expressed in acts of willing. Often writers seem to use 'Will' to include both the intention and the desire, but a difference between the two is not only important in general terms. In the specific context of Buddhist thought, 'will' - as cetan $\bar{a}$ - has specific functions and consequences distinct from forms of desiring.

Even acts of negation can be seen as formed from desires - desires to avoid or be rid of. But are there acts of will that do not derive from desires? As yet, I have left this possibility open, but what might they be like? We might view instinctive responses as acts of will, but not based on desire. I pull my foot away quickly from a spike I have trodden on - but does this work? I could be easily seen as having acted on a desire to avoid pain - and beyond this, might we even claim here that the act is so quick and unconsidered that I barely willed it at all? This complicates the relationship of desire and willing.

Might we have to re-position our view such that acts of 'Will' derive from desires, but that desires can, on occasion, lead to action without the intermediary of the will? This seems possibly to be the case, such as in the example of the spike above. This seems reasonable, but such desires as these seem qualitatively distinct from the more complex and cerebral considerations and wants that many of our desires seem to be. This attempted untangling of desire and willing is incomplete - and stands here only to try and offer a little initial clarification of these terms.

Moving to consider the nature of desire itself, while in the first chapter a significant quantity of the material is drawn from the approach of Continental European philosophy, for this initial issue of definitions, I turn to a proponent of a more Analytic style. In his book on desire, G. F. Schueler offers two senses of desire:

The distinction is that between two senses of the term 'desire': On one side is what might be called the philosophers' sense, in which, as 
G. E. M. Anscombe ${ }^{15}$ says, 'the primitive sign of wanting is trying to get', that is, the sense in which desires are so to speak automatically tied to actions because the term 'desire' is understood so broadly as to apply to whatever moves someone to act. ${ }^{16}$

Before we move to the second sense, it is worth noting that while this is broad in some ways, it is narrow in others. It seems almost behaviourist - denying an inner life other than as an analogy for the physical. Schueler continues to outline the second sense:

On the other side is the more ordinary sense, in which one can do things one has no desire to do, that is, the sense in which one can reflect on one's desires, try to figure out what one wants, compare one's own desires with the desires of others or the requirements of morals, the law, etiquette or prudence, and in the end perhaps even decide that some desires one has, even very strong ones, shouldn't be acted on at all. ${ }^{17}$

This is an important distinction. It would seem outright folly to adopt the first approach exclusively in this analysis. Buddhism seems to explicitly tell us that there are desires we should not act on, ${ }^{18}$ and it does nothing if not encourage us to reflect upon our desires. The second sense however is insufficient to act as a definition. Rather it describes some of the ways we relate to desires.

One aspect, which needs addressing by any initial discussion of desire, is that of the physical or bodily basis of much desire. While we may have sophisticated mental desires, ${ }^{19}$ much of our desiring has fairly obvious physical roots. Here another distinction is also required. On one hand we have basic physical needs - I am hungry and must eat; on the other, we have physically based desires that are less basic - I want cream cakes. The first category are described by Schueler:

One important set of cases of desire, often thought of as paradigm cases I suspect, are hunger, thirst, and the desire to eliminate bodily wastes. (We might want to add sexual desire to this list as well.) Such desires are ubiquitous and have a very distinctive and characteristic set of features. Each is connected to a corresponding biological need or drive. Each has a distinctive kind of 'object', such as food or water. Each, at least in its more intense manifestations, has a distinctive and (normally) unmistakable phenomenological character. ${ }^{20}$

This seems fairly reasonable, and we can clearly see what he refers to here. He goes beyond this to discuss other desires which may seem to mimic the structure of those of physical need, but are not as basic or fundamental. These he refers to (although, for reasons that will become obvious, I do not adopt this usage) as 'cravings'. 
Genuine cravings, such as the craving for chocolate or for tobacco, though they often seem to have a biological basis and may have a distinct phenomenological character, don't seem connected to needs in the same way, say, hunger and thirst are. ${ }^{21}$

He discusses these cravings, following them along a spectrum till they are far from the need to eat to live. He refers to when:

People sometimes speak of having a craving to see a Cary Grant movie or to go horseback riding. ${ }^{22}$

Here we have moved a long way from even, it would seem, the pseudo-biological craving for chocolate. Schueler then moves to desires that he does not see as 'cravings' at all (at least in the way he uses the term):

My desire to visit my sister is a genuine desire, which I might have or lack, but it is not a craving, I would say, even in the way that a craving to see a Cary Grant movie is, let alone in the way a craving for sweets is. ${ }^{23}$

So, it would seem that not all desire can be construed as derived from, or mimicking, our most basic need-type desires. These groups of desire - the biological, cravings, and non-craving desires, form by no means a comprehensive list. Schueler also discusses hopes and wishes, ${ }^{24}$ and even the peculiar example (drawn from Nagel) that if we did something (without being physically forced to do so in the most basic sense) then we desired to do so. ${ }^{25}$

A single definition is hard to come by, given the range here covered. Indeed, when I spent some time seeking to frame such a definition for this introduction I seemed to find myself spiralling into an endless task. From concern over this, and a sense that further discussions of desire are likely to be eclipsed by the discussions that follow, I say little more here. I treat desire as 'an active mental attitude towards an object, with the possibility of willing occurring as a result thereof'. While this may be a little 'safe' as a definition, it captures, I feel, most of what is generally included in the notion of desire.

\section{Desire as problematic}

Desire can be seen as potentially problematic for a number of reasons. First, it may lead us into conflict with other people - in a finite world with infinite desires, this seems inevitable. Second, particularly in a Buddhist context, desire may be seen as an enemy of calm and inner-peace. ${ }^{26} \mathrm{I}$ will refer, at various stages, to the idea of desire as 'the upsetter' for this very reason.

A third reason for desire's being of an at least ambivalent ethical nature is its relation to the world. In Buddhist thought, desire's problematic nature is a result not only of the ignorant (avijja) way that we want, but also of the nature of the 
world - and our ignorance of this. It is because all conditioned things are of a nature to pass away, because of the impermanent (anicca) nature of reality, ${ }^{27}$ that our desires are doomed to disappointment. Even if we do manage to get what we want - it will not last for ever, and neither will we. ${ }^{28}$ It is the impermanence, or transiency, of the world that condemns desiring to futility.

Awareness of this as, we shall see in Chapter 1, is found in Western as well as Eastern thought. Indeed, Jonathan Dollimore refers to this impermanence as 'mutability' ${ }^{29} \mathrm{He}$ considers it to be the factor that leads to the oft-remarked upon links in literature and art between desire (often sexual) and death. The Chapter 1, as well as those beyond it, returns explicitly to these issues.

\section{Scope of this study}

The topics covered here are both narrow and wide. In my consideration of Buddhism I retain a relatively narrow focus - on the material of the Pali Canon, and here more on the suttas than any other aspect, with the abhidhamma being used to provide further reflection and insight. ${ }^{30}$ Beyond Buddhism I cast a wider net, but why go beyond the borders of the Buddhist approaches which form the central plank of this study? I am interested in desire - and Buddhism, as found in the Pali Canon, has proved to contain the most engaging discourse on this. Accordingly, unless otherwise stated, whenever I refer to 'Buddhism', it is the early form of Buddhism as represented by the contents of the Pali Canon that I refer to. While I make some use of commentators such as Buddhaghosa, and post- and para-Canonical materials from the Theravāda tradition, I focus primarily on the Canonical texts themselves. I have given myself much freer reign regarding the non-Buddhist material, and explain why this is below.

\section{Approach and method 1: chapter outlines}

\section{Chapter 1 -desire in western thought}

In the first chapter, I offer an overview of how desire has been understood within Western thought, mainly but not exclusively by philosophers. Clearly there is a vast range of materials that I could potentially refer to and discuss in this context, but after wide reading around the topic, I have selected writers and thinkers who have something of interest to say regarding the nature of desire itself, or whose concepts of desire have particular relevance in the context of Buddhist thought.

When initially planning the first chapter, I considered trying to extract two or more specific conceptual models from the range of material therein, to form the basis of a comparison with Buddhist and Hindu ideas. For a number of reasons, I ultimately chose not to follow this approach. Such an approach seemed false, and the views of many thinkers involved seemed too complex and individual. Many positions on desire were predicated on particular metaphysical presumptions 
(or rejections thereof), and to abstract them from this seemed to be to oversimplify and misrepresent them. So rather than the construction of the conceptual models of desire, what I have sought to do is locate a number of central themes and issues that recur throughout Western thought. I will say no more here on the nature of the themes, but will conclude this section with a few words about the type of Western philosophy discussed in the first chapter.

The most oft-used distinction in modern mainstream Western philosophy is between 'Continental' and 'Analytic' types of philosophy. This distinction relates not only to the object of study - the content - but is in many ways a divide of style and attitude. To draw a rather caricatured version of both, let me offer a quick set of key features.

Analytic philosophy is often seen as being predominantly Anglo-American and as apolitical, seeking transparent, factual language, concerned with epistemology and logic, and impersonal in both tone and intent. Continental (as in Continental Europe) thought is often viewed as being more political and personal, is stylistically more interested in literature and its methods, seeks reflexivity to the author, and concerns itself more with ontology. Thus Continental thought is more interested in addressing life as an existential phenomenon. ${ }^{31}$ While such a brief and over-simplified picture might make even hardened philosophers wince, it reflects the way the two are often portrayed. ${ }^{32}$

We might expect then, given its more existential nature, to find desire as a more dominant theme in Continental thought than Analytic. To an extent this is the case, but far from exclusively. We have already seen a relatively analytic approach from G. Schueler, and will see more in Chapter 1. Further to this, the distinction between the two is not as hard as the impression of my, admittedly rather concise and generalising, summary above might indicate. In examining Western thought, I do not make a lot of this distinction, but it needs to be mentioned, for it does crop up intermittently.

\section{Chapter 2 - non-Buddhist Indian thought on desire}

The second chapter relates to non-Buddhist Indian religious views. I concern myself primarily with early Hinduism, but also pay some attention to the thought of Jainism. A certain proportion of this material might be seen as scene setting for the chapters on Buddhism, but not all of it fits this description, and my intent is broader.

Nonetheless, this background is important. If we are to take on board the Buddhist teachings regarding paticca-samuppāda - conditioned arising - we need to see what the conditions for the arising of Buddhist attitudes to desire were. Richard Gombrich argues strongly for such an approach:

To see the genesis of the Buddha's teaching as conditioned by the religious milieu in which it arose is to adopt a truly Buddhist standpoint which I also believe to be good historiography. ${ }^{33}$ 
I hope to give some sense of these factors, but while the Buddhist material is drawn from a narrow band of the spectrum of Buddhism available, the Hindu material particularly casts its net further.

In looking at Hinduism, I begin with the Vedas, and continue as far as the Käma Sütra. Why do I allow myself to range so far? Part of the reason for this is that I do not here go into the level of detail on Hindu thought that I do with the Buddhist material. Another component of the rationale for this, and the primary one, is that I wish to use the non-Buddhist portions to illuminate the ideas I discuss with reference to Buddhism. I take a particular phase of Buddhist thought, and use ideas from beyond it to help clarify, and initiate reflection upon, topics discussed therein; doing so has allowed me to look far and wide for material on desire.

In response to this, one might ask, 'Why not further yet?' Indeed, there is no account here of the Islamic understanding of desire, or the Judaic, and only passing interactions with Christian thought. There are numerous traditions I have neglected, and there are numerous reasons for this. First, there is not enough space to address all of these in one book (though as a future project it is appealing). Second, I admit a pragmatic interest here. I am a Western philosophy and religious studies graduate, with a postgraduate background in Hinduism, and as such have certain personal interests and areas of knowledge. In framing this project, such factors have played an inevitable part. However, I hope that I am being not purely partial in this sense. In my reading, Hinduism, and to a certain extent Jainism, clearly had much to say that impacted on, related to, drew on, and was responded to by, Buddhist thought. In Western thought I found what seemed like startling echoes of Buddhism, which are discussed in Chapter 5.

Overall, the second chapter looks to the Indian context of Buddhist thought, both before Buddhism's advent, and also with relation to the paths of desire Indian religions trod once Buddhism was on the scene.

\section{Chapter 3 -Buddhism and desire: the varieties of desire}

In this chapter I come to look at the Buddhist view on desire. The primary approach taken in this chapter is to try and see the terms used in Pali that could be construed as coming under my definition of 'desire'. This process gives rather a lot of terms, with a variety of meanings and senses, and of varying significance doctrinally. In seeking to view these terms in context, I become drawn into debates surrounding the doctrines and ideas the terms relate to. We see many of these issues as inter-related and overlapping. With reference to the way Buddhism views mental processes, Rune Johansson's words are particularly apt here:

According to Buddhist psychology, all psychological processes are dynamic, i.e. intentional and creative. The terminology referring to needs is particularly rich. ${ }^{34}$

It is this rich range of terminology that Chapter 3 seeks to investigate. 
When initially planning my approach to this study, I had hoped that by systematically examining a range of Pali terms for desire, I would be able to produce a coherent and consistent Buddhist typology of desire. Such an ambition, I soon discovered, would have required much more time and space, but as I argue in Chapter 3, is still likely to have been impossible. Such a clear typology is not, in my opinion, present in the Pali Canon.

Nonetheless, I have stuck with an approach of using Chapter 3 to primarily engage with the varieties of desire in Buddhism. This has enabled me to look at the ways that understandings of desiring are conceptualised and what responses and prescriptions are offered in the face of them.

\section{Chapter 4-Buddhism and desire: the dynamics of desire}

In the fourth chapter I build on the work of Chapter 3, and seek to place the Buddhist understanding of desire in context. The most obvious context is that of pațicca-samuppāda - conditioned arising - the way in which desires are seen as coming to be, and indeed passing away, from being.

In seeking to place desire in context, I also examine the location of desire. This takes us beyond the question of 'who desires', ${ }^{35}$ to look a little at the where and how of desire through interrogating the Buddhist notion of mind-body and their relations. ${ }^{36}$

Another key issue, which has been mentioned a little already here, is the relation of desire to ignorance and insight. Not only do I examine this topic in the fourth chapter, I also look at the status of 'views' themselves. I do so for two reasons. First, because knowledge is clearly seen in some Hindu and some Buddhist material as being of potential spiritual value. Second, because we are warned against attachment to views in interesting ways in Buddhism. Just as desires for good objects can still be potentially problematic if the desire is held in a certain manner, so a 'right-view' can be harmful if clung to, and indeed, treated as an object of desire. This investigation into 'views' not only mirrors the discourse on desire, but also seeks to deepen that discourse and extend it.

\section{Chapter 5 -Conclusion: desire and the transformation of living}

In the concluding chapter I draw together material from all the preceding chapters. As well as summarising my chapter conclusions, I offer a number of thematic reflections on desire. I consider the relationship of desire to ideas of freedom particularly spiritual freedom as liberation.

Following up material in Chapters 1 and 4 particularly, I look at the interplay of desire and reason, and the manner in which such a discourse has been characterised. Another key theme is the relation of desire to absence or lack. I here go beyond notions of desire as the lack of an object, but look to the ways in which desire can be seen to arise from an 'inner lack', both with reference to anatta and Western philosophy. 
I also consider the connections between desire and morality - the way desire is often cast as being in some way morally suspicious. After this I look at the connection of desire and death, following the ideas mentioned earlier in this Introduction.

I next examine the way in which concerns over desire are related to the extent and nature of love and passion in life. Here I address the question, 'Does the Buddhist goal of desirelessness drain all passion from life?' After this I look at the critical importance of notions of change and transience to the understanding of desire.

Before coming to my final conclusions, I have two sections that consider the personal and cosmic, respectively, senses of desire as a creative force. This may at this stage, given what has been said of desire, seem an odd topic. However, numerous sources and writers on desire conceive of it as a force with great creative power. I wish to answer the question, 'Is desire really the maker of the world?'

\section{Approach and method 2: key concepts}

\section{Language and expression}

Much of the time the concepts described in Buddhist texts are ones that may slip away from the grasp of language, away from its tendency to solidify that which is in flux, to stall the dynamic. This applies most obviously to nibbāna, but goes beyond this. It is hard to describe dukkha in less than a lengthy paragraph and even here we are aware that we have not done it justice. Buddhism, by the nature of its concerns, deals in a currency of experience. In spite of some of the grander claims of structuralist linguists, much of our mental life seems to remain stubbornly resistant to clear expression in language. It is with this caution from Goethe ringing in my ears that I tentatively approach central Buddhist ideas:

You needn't confuse me by contradicting! One cannot begin to speak without beginning to err. ${ }^{37}$

Given this, we must nonetheless go on. I draw attention to these problems only as a disclaimer, by way of seeking to explain the apparent manner in which I may, particularly in Chapter 5, appear to play a little 'fast and loose' when comparing Buddhist ideas to those in Western thought. While there often remains linguistic resistance to some of the comparisons, there being variance in the means of expressing them, I do so on the basis that they conjure up related, if at times difficult to express, psycho-spiritual connections. While I use the term a long way from its home, there seems, in this process, to be an element of 'analogical reasoning' (what Islamic ethics refers to, albeit in a radically different context, as qiy $\bar{a} s^{38}$ ).

\section{Kusala-Akusala}

The notion of classifying phenomena (dhammas ${ }^{39}$ ) as either kusala, akusala, or neutral is perhaps the key way in which we find actions or mental occurrences 
judged in Buddhism. But in what way are they being judged? Bhikkhu Thich Nhat-Tu claims that kusala and akusala are: 'the primary terms to evaluate human behaviour and morality. ${ }^{40}$ As we might imagine in the light of this, the judgement is one applied to actions, and the mental states that initiate action - but also includes non-act-initiating mental states. We can see how such a judging mechanism might be presumed to be essentially a moral one.

However, despite this feeling that it may be a moral term, there has been a certain shying away from the translation of kusala/akusala in explicitly moral terms, such as good/bad. Why is this the case? First, kusala seems to have a broader meaning than just 'good', as the PED indicates, where it is defined as: 'clever, skilful, expert; good, right, meritorious' ${ }^{41}$ However, the PED goes on to say that it is 'Esp. appl. In moral sense (= puñña)' ${ }^{42}$ So while kusala (and its opposite akusala) are terms with a moral component, they seem to go beyond this: they indicate some notion of competence. Indeed, we often find them used in such a manner. Lance Cousins points this out:

In many of the passages in which it occurs it is simply a case of mentioning proficiency in some art of craft. $^{43}$

Cousins lists around thirty Canonical occurrences of kusala in this context. Further to this he also notes cases where an analogy is drawn between some mundane skill and a spiritual competence. The most common translation, then, of kusala is as 'skilful', ${ }^{44}$ and this is often seen to encompass both the meanings, of competence in some task, ${ }^{45}$ and its more moral sense. The latter usage gives a very specific tone to the way 'good' actions are viewed. Using such a translation seems to de-substantialise notions of good and evil, and seems to portray moral and spiritually benign behaviour (mental and physical) in terms of a competence - a skill; they are, then, something not to be simply followed, but learnt and mastered.

Not everyone is happy with this translation of kusala as 'skilful'. One of the most sustained arguments against such a usage is found in the work of Damien Keown. I shall look briefly here at his case for adopting a different translation (and therefore a slightly altered interpretation). His basic definition is a functionalist one, that is to say that kusala is to be understood by the role it plays. This role is that of moving one in the direction of enlightenment:

Kusala denotes those things which are to be pursued if enlightenment is to be attained. Its contrary, akusala, characterises whatever is negative in this respect and is accordingly to be shunned. ${ }^{46}$

This is not a particularly controversial definition and Keown is able to quote Canonical sources which are unambiguous in supporting such a position. After establishing which side of the moral fence, as it were, kusala lies on, and its association with nibbāna and arahatship, Keown moves on to discuss the translation of kusala. In looking at possible translations, what he is partly doing is trying to fix 
the meaning of the term, to find out what it 'really means'. It is here that Keown disagrees with the common translation of kusala as 'skilful' and also makes claims regarding what he feels to be the implications - problematic ones in his view - of the term 'skilful'. He begins by claiming that the translation of kusala as 'skilful' ties in with a specific interpretation of the nature of Buddhist ethics:

It is very common for kusala to be rendered as 'skilful', but it should be recognised that this translation carries with it a specific implication for the nature of Buddhist ethics, namely that it is utilitarian. Even then, it is a poor translation on aesthetic grounds, and we may note that utilitarian philosophers retain the traditional moral terminology of 'good', 'bad', 'right', and 'wrong'. ${ }^{47}$

I think this is an interesting stance, but it raises a number of potential problems. Does 'skilful' imply utilitarianism? And even if it does, is that unrepresentative of Buddhism? I will briefly address the second point first.

Keown argues at some length, in The Nature of Buddhist Ethics, against a utilitarian interpretation of Buddhist ethical thought, and I do not intend to either fully engage with his position or object to it very strongly here. To do so would be going a little further than my self-imposed remit. However, I do wish to draw attention to one of his key objections:

\begin{abstract}
An action is judged to be kusala to the extent that it is harmonious with nirvanic values, and not to the extent that its consequences display or promote certain qualities. In Buddhism there is no ex post facto conferral of rightness upon actions as there is in utilitarianism. An action is right or wrong from the moment of its inception ${ }^{48}$ - its nature is fixed by reference to nirvanic values and it cannot subsequently change its status. Wrong (akusala) acts cannot turn out 'in the event' to have been right by virtue of their proximate or remote effects; nor can right (kusala) acts turn out to have been wrong in view of their consequences. For a utilitarian theory of ethics, however, both of these are real possibilities since rightness and goodness are separately defined. ${ }^{49}$
\end{abstract}

This is flawed, not because it misrepresents Buddhism - which I do not think it does - but because it simplifies utilitarianism. Are there not forms of utilitarian thought which are concerned with the intended consequence? If there are, a 'good' act remains good, even if its aims are thwarted. Here the locus of morality is still intent, but intent with reference to desired consequences. Not only does this seem not too far from a utilitarian position, it is also - in my view - reasonably close to a Buddhist position. Does not Buddhism promote values whose expression seeks specific consequences? It would seem so in at least three ways. First, and most obviously perhaps, there is the matter of karmic consequences. Second, there is the consequence of moving one forward towards liberation, and third the most important 
desirable consequence of action is surely the reduction of $d u k k h a$ (although this is likely to be, in varying ways, related to the previous two).

However, I do not wish to pursue this further here, as I am also unsure that the translation of kusala as 'skilful' necessarily implies a utilitarian ethic anyway. 'Skill' does not have to be seen as mechanistic in the way that utilitarian ethics are often portrayed.

To take up a remaining issue, I do not have an aesthetic problem with 'skilful'; indeed I rather like it. From it I take a sense of ethical behaviour (and especially the learning of this behaviour) as a craft. In seeing Buddhists as being some kind of ethical apprentice, I feel we get a good feel of the notion of moral training to which Buddhism seeks to subject us.

Furthermore, and this is a personal view (but we are talking aesthetics here), I have always found the term 'skilful' to be deeply evocative. For me it has conjured images of one who is skilled at living. Rather than implying utilitarianism's hedonic calculus it seems more akin to Aristotelian notions of the rounded individual and ideas of eudaimonia. I have long felt 'skilful' to be useful as a means of making morality analogous to craftsmanship in a sense that flatters morality rather than reducing it. In this way morality becomes the craft of living well, of living in accordance with a well-measured insight into the nature of things.

We can perhaps see how some might view the notion of 'skill' as removing some qualitative feature from morality. But this is the case only if one wishes to posit a moral or meta-ethical view which relies on morality being sanctioned by something external to the world. This is in accordance with the technical paradigm implied by 'skilfulness'. This does not mean we have to see ethical behaviour as 'calculating' (a term which often seems to be derisory when applied to human motives and behaviour). Rather we can conceive of Buddhist ethics as the development of a way of thinking, and acting, free from the shackles of the Self-delusion, leaving us to respond out of an insightful compassion. This is an ethic of fluidity, a broadened moral horizon which opens a vista beyond the narrow confines of both utilitarianism's hedonism and deontology's unsustainable metaphysical dualism. In this sense Buddhist ethics $d o$ go 'beyond good and evil', not in that they transcend morality, but in that they propose a moral outlook which can make sense only in a holistic context of the Dhamma. Morality is then not partitioned off from psychology or from analytic philosophical analysis; it really is part of the path. It is on this basis that I retain the translation of 'skilful' for kusala. ${ }^{50}$ Another possible option might have been to translate kusala as 'wise', and while this seems fairly reasonable, it does not, for me, have quite the ethical register, and seems not to capture much that 'skilful' does.

One final point needs addressing with regard to the notions of kusala and akusala. We must be clear that they represent, to a significant extent, a distinction of degree, rather than purely of type. ${ }^{51}$ Actions can be relatively kusala, and less or more akusala. Throwing my pen across the room out of frustration may be a form of anger; it is akusala (it will damage my inner calm, make me unhappy, etc.); but it is not as akusala as kicking the cat (harming a living being, as well as giving in to anger). 
The discussion of kusala and akusala is important, for when we come to look at the types of desire found in Buddhism, it is primarily a kusala-akusala assessment of them that I wish to make, alongside seeing if the Canon makes such an assessment.

\section{Approach and method 3: sources and textual issues}

My key sources here are, at least for Chapters 3 and 4, the Pali Canon, as preserved by the Theravāda tradition. I am greatly indebted, with regard to these texts, to the producers of the Chattha Sangāyana CD-ROM $\left(\mathrm{CSCD}^{52}\right)$. The CSCD represent the Burmese (or Myanmar) version of the Pali Canon, but I have sought to indicate where there are differences from the version used by the PTS. ${ }^{53}$

However, my primary purpose here has not been to offer new translations of texts. My skills in Pali are limited, and I am not seeking to engage in a form of technical linguistics. In deciding whether to cite an existing translation, or to offer one of my own, a number of factors have been involved.

If a short piece of Pali has been straightforward I have usually offered my own translation, and I have tried to offer my own rendering of passages of particular importance to the arguments I am presenting. I have relied on the translations of others where I have deemed that I could not improve on their version, and where there seems no other sensible reason for devoting the time and sweat required - only to replicate what another has already done.

I feel this represents a balanced approach, both in terms of providing the reader with appropriate details, and use of my time. In all cases, even when using the translations of others, I have sought to provide the Pali, so that the reader with appropriate skills may judge the translations for themselves. ${ }^{54}$

In terms of other sources, I offer here only the briefest of literature reviews. My reading began with the Philosophy East \& West pieces discussed earlier, and for the Buddhist material I scoured a range of books. Few address the topic of desire exclusively, but I am indebted to Bruce Matthews' Craving and Salvation and Robert Morrison's Three ${ }^{55}$ Cheers for Tannhā in challenging my views and providing numerous useful references. With regard to the material in Chapter 1, the place I began was with the special edition of the journal Continental Philosophy (vol. VII), which was dedicated to the topic of 'Philosophy and Desire', and Jonathan Dollimore's fascinating Death, Desire \& Loss in Western Culture. These both broadened my horizons and again gave me much to follow up.

For the Hindu material, I was fortunate enough to have access to a number of pieces by Dermot Killingley, who has written extensively on desire in Hindu thought. These, along with Dermot's advice, allowed me a significant foothold in dealing with this material.

\section{Conclusion: aspirations}

While this section is not really a conclusion - I have at this stage yet to reach any - I do want to take this opportunity to set out my aspirations for this work, which I will then return to in the final conclusion. 
I seek, by the end of this book, to have surveyed the range of views on desire found in Western philosophy and in non-Buddhist Indian religious thought. Further to this, I aspire to offer a critical interpretation of the understanding of desire, in its variety, within the form of Buddhism represented by the Pali Canon. By drawing together this material, I wish to articulate my own understanding of desire, and the manner in which the Buddhist position I outline can be seen to not only offer an understanding of desire as a phenomenon, but also offer a response to desire. As I reiterate elsewhere, my primary goal here is academic; but this academic enterprise has led me to more therapeutic conclusions, more so than I was expecting myself when, back in the mists of time, the project was initiated. 


\title{
DESIRE IN WESTERN THOUGHT
}

\author{
I shall go down \\ to the lovers' well \\ And wash this wound \\ that will not heal \\ beloved soul \\ what shall you see \\ nothing at all \\ yet eye to eye \\ depths of non-being \\ perhaps too clear \\ my desire dying \\ as I desire. ${ }^{1}$
}

\section{Introduction}

This chapter has something of a mountain to climb. It may seem a foolhardy expedition, given the looming bulk of the Western philosophical canon; indeed, it probably contains enough tomes of metaphysical and analytic speculation to build an actual mountain. Nonetheless, others might suggest that the quantity within this great body of thought given over to the explicit consideration of desire would amount to only a modest molehill.

Some have gone as far as to suggest that the whole approach of this philosophical canon is opposed to engaging with desire, seeing it as the antithesis of the philosophical telos:

No doubt the bulk of the Western tradition has sustained skepticism toward the philosophical possibilities of desire, and desire has been figured time and again as philosophy's Other. As immediate, arbitrary, purposeless, and animal, desire is that which requires to be gotten beyond; it threatens to undermine the postures of indifference and dispassion which have in various modalities conditioned philosophical thinking. ${ }^{2}$ 
This does not mean that Western philosophy leaves the subject unexamined, but is in line with the manner in which we find it treated. As I discovered when I began researching this chapter, much of what has been written consists of asides, digressions and adjuncts to the matter ostensibly under scrutiny. This is not universal, and combining the direct engagements and the sideways glances provides a significant quantity of material. In reviewing this material, I have two primary purposes.

First, I aim to clarify the notion of desire. Is it an impulse, an emotion, a sub-class of willing? Is it a sublimation or expression of our genes' reproductive imperative? These issues pervade this chapter. In a way, the word 'desire' is a curse to Western thinkers - it means too much and too little. On one level it is a simple mental attraction to an object, while on a broader view it could be applied to all mental states - for all mental states might be said to take an object, and an attractor-repellent relationship to that object.

Within this chapter, this diversity of interpretation of the very nature of desire is revealed. Furthermore, I show here the work that 'desire' - as a concept ${ }^{3}-$ is made to do. For the Stoics it is part of a futile striving that needs to be reined in, in the work of Deleuze it forms part of a critique of capitalism, in Nietzsche it is, in part, an element of breaking free from 'herd' morality, and more.

As we shall see, analyses in Buddhism also have very specific ends to which the theories of desire are orientated. ${ }^{4}$ Indeed, if we wanted to examine the motives of those writing on desire, we would find as much diversity as we do in definitions of desire.

The second aim of this chapter is to find ways of theorising desire. Ways of locating desire within conceptual schemes are one thing - but we do need to be alert to the dangers pointed out by Nietzsche of our 'Will-to-system'. 5 My goal is more to demonstrate the existence of these discourses of desire. What I will show is that in the West there are numerous ways in which desire is conceptualised. We might go so far as to argue that there exist competing models of desire, and we shall see that some more contemporary writers look back with scorn and suspicion on some of the ways 'desire' has been viewed in the past.

One aspect of Western thought I do not seek to engage with in detail is what Patrick Fuery calls 'a radical politicisation of desire', ${ }^{6}$ in the work of writers such as Luce Irigaray and Julia Kristeva. These writers engage with the ways in which desire can be said to be 'socially constructed', and the manner in which sexual desire is related to issues of gender and sexuality. I have to set aside these discourses, partly for reasons of space, and partly because my focus here is already fairly wide, and would be in danger of becoming overly diffuse were I to permit myself to extend it any further.

Another noteworthy feature of Western writing on desire is just how much of it seems to feel that a discussion of desire is the same thing as a discussion of sexual desire. A number of texts consulted in the process of this research seemed to view 'desire' as synonymous with sexual desire. ${ }^{7}$ For this, perhaps we are to blame Freud. ${ }^{8}$ He seems, at least in the popular imagination, to be partly responsible for the view that all desire is sublimated sexual lust. 
To attribute such a view to the writing of Freud is disingenuous, but he does seem to give the Id - in a move reflecting the Platonic tri-partite Soul - a significant and powerful sexual component. As Leslie Stevenson notes:

It is a vulgar misinterpretation of Freud to say that he traced all human behaviour to sexual motivations. What is true is that he gave sexuality a much wider scope in human life than had been formerly recognized. ${ }^{9}$

It is worth noting that Freud does not derive his theory exclusively from his clinical observations of those in mental distress. Indeed, R. C. Solomon claims:

It is not hard to appreciate the importance of Schopenhauer in Freud's model of the mind. ${ }^{10}$ The libido is an only slightly personalized version of Schopenhauer's Will, juxtaposed against a rational system of ideas. ${ }^{11}$

This even extends to the ideal response to this deep-seated drive. The primal thrust of the libido, like the Schopenhauerian Will, is something we struggle to control - for fear of its potentially destructive effect on our lives. Solomon notes how Freud sees us as in need of a type of liberation from this base appetite:

he insists that we struggle against the libido and, through self-understanding, free ourselves from its power. ${ }^{12}$

Of course a Freudian analyst may not see the life of a bhikkhu as the best way to achieve this, ${ }^{13}$ and see their chastity as an attempt to achieve the repression of the libido rather than liberation from it.

In this project then, desire is not to be taken purely in a sexual context. Indeed, some thinkers might go as far as to suggest that all sexual lust is a sublimated form of a desire for power, or even a general desiring that has no inherent type of object, but that seeks expression through a variety of means. Such approaches may indeed be seen as being a form of Schopenhauer's assertion that the general Will - which all our smaller acts of willing are examples of - is a prime force with no specific goal itself. ${ }^{14}$ This conception, though, is not universal; some see desire working the other way round. This is to see desire as brought about not by some deep inner yearning from within - but rather as arising from perception. William Blake writes:

Man's desires are limited by his perceptions; none can desire what he has not perceiv'd.

The desires \& perceptions of man, untaught by anything but organs of sense, must be limited to objects of sense. ${ }^{15}$

This view may however be seen as relating to what we want, rather than why we want in the first place - and therefore there is no reason that the two views 
(desire as force arising from within, and the objects of desire arising from perception) need be seen as incompatible. We might argue that Freud, coloured by his clinical experience and personal preoccupations, lays a model over Schopenhauer.

Clearly these different writers are trying to do different things, but they do seem to have one aspect of mutual concern - ethics. Be it therapeutic - as Freud is and Schopenhauer aspires to be - or philosophical, religious or political, the moral status of desire has significance for us all. So pervasive in our consciousness is desire that even the driest of analytic philosophers cannot ultimately suppress this import. When an analytic philosopher seeks to portray their discussion of desire as a neutral, objective account of the relation of belief and intent, or to identify belief with either action or linguistic usage, they may succeed in eradicating all explicit references to 'soft' topics such as ethics and human lived experience. However, the answers to these driest of questions do have ethical implications. What and how we choose; how we have meta-desires, which do or do not over-ride first-order desires; how desire can become addiction; these are all issues which the conclusions of analytical investigation into desire will have consequences for, even if they are left unstated.

A final note though before I discuss these various views of desire, for most do seem to rely on a specific model of reality - a metaphysical backdrop to their notion of desire. This seems to represent the final victory of Heraclitus, in that nearly all writers on the topic concede the ever-changing nature of the world. Of course, we might question this assertion - what of the Platonic forms? By 'world', I am here referring (in a Kantian sense) to the phenomenal world - the world as the object of our lived experience. It is indeed Plato's great integrationist project with regard to pre-Socratics such as Heraclitus and Parmenides ${ }^{16}$ that results in the idea of the forms. By having the forms take on the roles of permanence and stability, Plato is able to concede the world of experience to change and flux. The majority of the views presented in this chapter seem predicated on this belief in reality as flux, or at the very least subject to change, which will be teased out as we examine them.

It is also worth noting here that the historical development of ideas about desire is not that of a single juggernaut rolling forward. Towards the end of this chapter, much is said about new and intriguing ways of viewing desire, but not all subscribe to them. We find a very different approach in the allegedly ahistorical discourse of analytic philosophy. In response to the question 'What are desires?', in a tone of grand neutrality befitting an analytic philosopher, G. F. Schueler seeks to offer a clear, unambiguous way of approaching desire. Before he begins he rules out the application of 'want' as 'desire' to non-sentient entities:

I will ignore uses of 'want' and 'desire' and their cognates where these terms can apply, literally and nonmetaphorically, to things other than sentient beings, e.g., where 'want' just means 'lack' or perhaps 'lack plus need' as when we say the house wants painting. ${ }^{17}$ 
However, in the realm of the sentient he seems happy to allow 'lack' to form a key component of desiring. ${ }^{18}$ This notion recurs in this chapter, and is revisited in Chapter 5.

'Lack', or absence, or deficiency is seen by many of those below as the defining characteristic of desire. No matter what the object, no matter which of the staggering diversity of desires we are discussing, many thinkers seem to feel that this definition carries the weight of both logical necessity and truth by definition. But, as we shall see, a healthy counter-tradition exists.

\section{An ancient lack}

The monastic man is an artist. The philosopher Appoints man's place in music, say, today. But the priest desires. The philosopher desires.

And not to have is the beginning of desire.

To have what is not is its ancient cycle. ${ }^{19}$

Some feel that the whole history of Western engagement with desire is a repeatedly lost battle with notions of rationality. These approaches also often contain the notion of desire as 'lack'. This seems regularly linked to theories that either condemn desire outright, or seek to make it subservient to reason - which regularly privilege reason over desire. This can be seen as beginning with Plato, and it is unquestionably the most commonly encountered view:

In the struggle between reason and desire, the philosophical tradition from Plato to Kant has given the prize to reason. Reason ought to rule desire. ${ }^{20}$

It is this dominant model of desire that leads to its vilification. So much so that Jonathan Dollimore is on safe ground when he characterises St Augustine's influential position on desire with the words: "human desire is a permanent source of misery. ${ }^{21}$ Indeed, Augustine goes further and recognises the way that seeking to solve the problems presented by our desires is not just to satisfy them, as John Armstrong notes when summarising Augustine's view:

Desire then, is organic: it grows. The more you feed it, the more you give it what it wants, the bigger and stronger it gets. And of course, the stronger our cravings, the less we feel satisfied. ${ }^{22}$

Returning to Plato, we can see this idea that desire relates closely to 'lack'. In Plato's Symposium Socrates is questioning Agathon about desire:

And does he desire and love the thing that he desires and loves when he is in possession of it or when he is not.

Probably when he is not. 
If you reflect for a moment, you will see that it isn't merely probable but absolutely certain that one desires what one lacks, or rather that one does not desire what one does not lack. To me at any rate Agathon, it seems as certain as anything can be. What do you think? ${ }^{23}$

Of course, this being a Socratic dialogue, Agathon is dialectically doomed to concur, leading to Socrates' conclusion:

Such a man, then, and everyone else who feels desire, desires what is not in his present power or possession, and desire and love have for their object things or qualities which a man does not at present possess but which he lacks. ${ }^{24}$

Here desire and love are based on absence, or perhaps on awareness of this absence, what we might call a 'felt lack'. The Symposium is renowned for the account ${ }^{25}$ of how we came to desire from the splitting of us into the kind of beings we are now. Originally, in this story, humans are four-legged and two-faced, but they attack the gods and Zeus slices them in two. This leads to a specific way of interpreting the nature of love:

Love is the yearning of each part to find its original, complete state. The perfect lovers are those who were originally joined together. ${ }^{26}$

This mythic backdrop inevitably influences the view of desire taken in the dialogue. As Dollimore notes:

Origination in a division which is a kind of death, desire becomes an experience of lack rooted in loss; caught up somewhere between past loss and future lack, it will remain unrealizable and always come to consciousness as the seemingly inescapable condition of restlessness, dislocation, lack - and anxiety. ${ }^{27}$

The view of desire found in Plato is also found to an extent in the Stoics such as Seneca. Indeed, Seneca sounds a little Buddhist when he emphasises the importance of becoming reconciled to the transient nature of the world:

No good thing renders its possessor happy, unless his mind is reconciled to the possibility of loss. ${ }^{28}$

Here we begin to see the recognition of the way our wants are endlessly frustrated by the nature of reality. Indeed there is no exaggeration in Dollimore's comment on Seneca's position:

Our desires are cheated by the mutability which characterises our existence. ${ }^{29}$

Returning to Plato, we can see desire being characterised as 'lack' potentially leading to an ethical suspicion of desire - the belief that it is possibly harmful and in need of 
suppressing, eliminating or at least severe regulation. With Plato we have the clear view that the 'appetites' must be subjected to the rule of the 'higher' elements of the Soul. In Book IV of The Republic a consensus is reached regarding the make-up of individuals. ${ }^{30}$ A person is made up of reason, 'spirit' ${ }^{31}$ and the appetites. These are seen as analogous to elements of the political state that form the ostensible telos of the book. Like the state, the way for the individual to best be, is in harmony. This harmony however is reliant on one element having dominance over the others:

So, the reason ought to rule, having the foresight and wisdom to act for the whole. ${ }^{32}$

To be self-controlled is seen as a sign of wisdom and internal harmony:

And we call him wise in virtue of that small part of him which is in control and issues the orders, knowing as it does what is best for each of the three elements and for the whole made up of them.

Yes, I agree.

Then don't we call him self-disciplined when all these three elements are in friendly and harmonious agreement, when reason and its subordinates are all agreed that reason should rule and there is no civil war among them. ${ }^{33}$

I think we need no clearer statement than this to demonstrate where Plato stands. Due to the nature of desire, it needs to be subordinate to reason. Plato however does not go so far as recommending the total avoidance of desire. This indicates that desire is not inherently wicked, but is dangerous and if uncontrolled is potentially ruinous. Without desire being held in check, chaos may ensue, so the firm hand of reason must rule the person, just as the philosopher-king must rule the state. As we shall see later, self-control is valued highly in Buddhism, but we might not wish to see reason as that which should ideally wield the control.

After Plato, we find desire cropping up in the work of Aristotle. It is perhaps worth recognising that Aristotle is also no outright condemner of desire. It seems, in The Nicomachean Ethics, to be a case of making sure one has the 'right' desire. Desire, as process, is described in terms of attraction or repulsion, which gives it something of a psychological tone:

What affirmation and negation are in thinking, pursuit and avoidance are in desire. ${ }^{34}$

He continues in this passage to offer a view of how desire fits in with virtue and character - key Aristotelian values:

so that since moral virtue is a state of character concerned with choice, choice is deliberate desire, therefore both the reasoning must be true and the desire right, if the choice is to be good, and the latter must pursue just what the former asserts. ${ }^{35}$ 
While desire is here still to be pointed in a direction decided by reason, we see the necessity of them working in tandem demonstrated by Aristotle. In Aristotle's view, desire - or the appetites - are to be less enslaved to reason than in Plato's approach. Aristotle sees desire less as something to be subdued. Indeed, Aristotle is renowned for providing a much richer and deeper engagement with the actuality of human character than the idealising of Plato. More evocative than Aristotle, although quite possibly also more pessimistic, is the view we find in Ecclesiastes.

\section{A striving after wind: Ecclesiastes and Judaeo-Christian thought}

While I am not going to attempt to draw a lot of Western religious thought into the gravitational pull of this work, there is one Biblical text that it seems a writer on Western thought regarding desire (and in particular the futility of desire) cannot (or at least should not) ignore: that is the book of Ecclesiastes.

Ecclesiastes opens with a famous and evocative claim regarding the futility of our existence. ${ }^{36}$ The misguided nature of our hopes and dreams hints at the impossibility of ever fulfilling our desires:

The words of the Preacher, the son of David, king in Jerusalem.

Vanity of vanities, says the Preacher, vanity of vanities! All is vanity. What does man gain by all the toil at which he toils under the sun $?^{37}$

Later in Ecclesiastes Chapter One, life is shown as a futile seeking, a running after what cannot be caught:

it is an unhappy business that God has given to the sons of men to be busy with. I have seen everything that is done under the sun; and behold, all is vanity and a striving after wind.

What is crooked cannot be made straight, and what is lacking cannot be numbered. ${ }^{38}$

The phrase 'all is vanity and a striving after wind' is a theme throughout Ecclesiastes. This view of humanity and the universe we inhabit may seem at odds with other characterisations of the Judaeo-Christian world view. But, as Dollimore comments:

From its own time onwards Ecclesiastes has been regarded as one of the most heretical books in the Bible. ${ }^{39}$

The comparison of Ecclesiastes to Stoics such as Seneca is hard to ignore. The book makes clear that our chasing after things of this world for answers is pointless, 
as we see in the quotation that opened this book:

All the toil is for his mouth, yet his appetite is not satisfied. For what advantage has the wise man over the fool? And what does the poor man have who knows how to conduct himself before the living? Better is the sight of the eyes than the wandering of desire; this also is vanity and a striving after wind. ${ }^{40}$

Indeed, Ecclesiastes is clear on desire:

He who loves money will not be satisfied with money; nor he who loves wealth, with gain: this also is vanity. ${ }^{41}$

To an extent, these verses place Qoheleth ${ }^{42}$ as the condemner of desire; a religious call to turn our attention from worldly matters to spiritual ones. However it is in more than tone that Ecclesiastes goes further than this view. It indicates that life is a joyless venture, a place in which we will find frustration. Indeed the exhortation, as Dollimore reads it, comes across rather like a Stoical or Epicurean assertion:

The positive notes in Ecclesiastes add up to a resigned, undefiant, form of carpe diem...

... Be grateful for being alive, no matter how briefly; enjoy the pleasures of life, even though they are outnumbered by sorrow. ${ }^{43}$

Ecclesiastes offers only this limited answer to the nature of the world and the problem that causes us. While limited, its evocative setting out of the problem is undeniably powerful. This picture of the world is not so divorced from Buddhist accounts. ${ }^{44}$

Elsewhere in Christian thought, we often find dissatisfaction with expressions of desire that do not relate to God. Looking back at the indiscretions of his youth, St Augustine is in no doubt of the immorality of his past when he "muddied the stream of friendship with the filth of lewdness and clouded its clear waters with hell's black river of lust'. ${ }^{45}$ After the lust, he looks for love, but even upon finding it, finds no ultimate satisfaction there. This is relevant here, as he sees in joy the manner in which it is mixed with pain:

My God, my God of mercy, how good you were to me, for you mixed much bitterness in that cup of pleasure! ${ }^{46}$

Indeed, desire as a wearying burden is a common thread in much Western thought, as John Armstrong notes:

In St Augustine's eyes, one of the things we long for is relief from the apparently futile cycle of desire - a theme echoed 1,500 years later by Schopenhauer. ${ }^{47}$ 
Elsewhere, we find - as we shall also see in Chapter 2 - the notion of desire for God. In Christian thought, we can find shelter by reorientating our desires Godward. This is a recurrent theme in much Judaeo-Christian thought. The idea of yearning or longing after the divine is expressed articulately in the Psalms:

As a hart longs,

for flowing streams,

so longs my soul

for thee, O God.

My Soul thirsts for God,

for the living God. ${ }^{48}$

We would be guilty of negligence if we ignore one verse from elsewhere before we move on from Christianity and the Bible. Here the transience of the phenomenon of humanity is bemoaned and seen as depriving our existence of meaning:

Man that is born of a woman is of few days, and full of trouble.

He comes forth like a flower, and withers; he flees like a shadow, and continues not. 49

This view brings to the mind notions of desire as linked to death.

\section{Shakespeare: love, death and desire}

Despite the vastness of Shakespearian material on desire, I want to restrict my examinations here to one sonnet, maybe even one line. I will quote the whole sonnet to show the context:

My love is as a fever, longing still

For that which longer nurseth the disease;

Feeding on that which doth preserve the ill,

Th' uncertain sickly appetite to please.

My Reason, the physician to my Love,

Angry that his prescriptions are not kept,

Hath left me, and I desperate now approve

Desire is death, which physic did except.

Past cure I am, now reason is past care,

And frantic mad with evermore unrest;

My thoughts and discourse as mad men's are,

At random from the truth vainly express'd;

For I have sworn thee fair, and thought thee bright,

Who art as black as hell, as dark as night. ${ }^{50}$ 
In the light of discussions about Plato and the role of reason in relation to desire, I am particularly struck by the image of reason as 'physician to my Love'. Love here is a sickness, ${ }^{51}$ and reason can offer the only remedy. Alas, though, for the love is too strong for reason, overpowering it - so much so that 'reason is past care'. But to come to the line which led me to quote this passage 'Desire is death'. A striking assertion, no doubt, but what are we to make of it? Dollimore offers an answer, albeit one that acknowledges the (surely intentional) ambiguity:

The starkness of the statement should not obscure a lingering ambiguity and ambivalence: it means most obviously 'I experience, I demonstrate reluctantly, in desperation - that desire is death': 'Racked with an impossible, contradictory, self-annihilating desire, I desire death. ${ }^{52}$

While unconvinced that we are to read this primarily as 'death is better than this hell of desire, 53 as Dollimore does, I see the sonnet as both the embracing and rejection of desire. Here is one whom passion has claimed, but the victim retains enough therapeutic rationality to recognise their fate, if not avert it. ${ }^{54}$

'Desire is death' in the sense also that desire is a reaching out - a belief in future possibilities. But desire as a reaching forward always pulls us forward. It drags us, willingly at times, and in torment such as in the sonnet at others, but always we remain under the sway of this temporal gravity - onwards to the grave. And as we must pass, so must all we desire, be it sentient or not; indeed the Buddhist notion of anicca casts the world in just such a light.

We can find these themes expressed in poignant detail of course in Romeo and Juliet, which, at least on one level, can be read as a cautionary tale on the haste and excesses engendered by unfettered passion - and its ability to psychologically outrun our reason. In this race reason is left, panting and shaking its head sagely, behind us as desire drives us ahead, seemingly to the object of our desire - but finally, always, to death.

That death and desire are close bed-fellows is a commonplace claim - but it may seem an odd one. As Dollimore points out, haven't we got it the wrong way round?

after all, desire is on the side of life, life is opposed to death, therefore desire also must be opposed to death... although manifest and pervasive in Western culture, especially its art, this age-old connection of death and sexuality does become confusing when we stop to think about it. ${ }^{55}$

But, as noted in the introduction, it is the changing nature of the world that dooms desire to this role - at least for those that see desire as predominantly characterised by lack. In this context desire becomes necessarily connected with finitude; death, then, represents the ultimate form of finitude. 


\section{Surveying desire: Hobbes, Spinoza, Locke and Hume}

Beasts love like men, if men in lust delight, And call that Love which is but appetite. ${ }^{56}$

Moving onwards in our history of desire, we come to Hobbes, and to a distinction which crops up intermittently throughout this history. The love/desire distinction, whereby desire ceases upon attainment of its object, whereas love continues in the presence of its object - found in the Symposium - is found throughout Western thought. Here desire is understood primarily through lack. In Hobbes we find this expressed explicitly:

That which men Desire, they are also sayd to LOVE: and to HATE those things, for which they have Aversion. So that Desire, and Love, are the same thing; save that by Desire, we always signifie the Absence of the Object; by Love, most commonly the Presence of the same. ${ }^{57}$

Spinoza offers a twist that links the physical roots of desire with consciousness, as well as making a central ethical point that resounds as rather contemporary: ${ }^{58}$

Desire is appetite with consciousness thereof. It is thus plain from what has been said, that in no case do we strive for, wish for, long for, or desire anything, because we deem it to be good, but on the other hand we deem a thing to be good, because we strive for it, wish for it, long for it, desire it. ${ }^{59}$

Before moving on to the great British (well, Scottish) empiricist and sceptic, Hume, I pause briefly in the works of one of his antecedents, John Locke. Locke, born in the same year as Spinoza (1632), sees desire not so much as appetite as an uneasiness:

Desire. The uneasiness a man finds in himself upon the absence of anything whose present enjoyment carries the idea of delight with it is that what we call desire; which is greater or less, as that uneasiness is more or less vehement. ${ }^{60}$

The connection here of desire and 'uneasiness' is intriguing. It can be seen as echoing the close links in Buddhist thought between desiring and dukkha, especially the sense of dukkha as 'dis-ease'. This sense of desire as a form of mental disturbance is followed up in Chapters 2 and 3 in some detail. It is worth noting though that while Spinoza sees desire as uneasiness, in Buddhist thought we more usually encounter desire as leading to the dis-ease that is dukkha.

We have encountered the view that reason's role is to keep desire in check, to stop our wants overwhelming us. Not all would concur, some see reason as a mechanism of fulfilment rather than as a regulator. 
David Hume is famous in this respect. Hume's approach is to relegate reason to an instrumental role - in particular with regard to morality. Reason is part of the means whereby we fulfil our desires. But reason should not, indeed cannot, hope to be the element that selects what we want. As he states:

Reason is, and ought only to be the slave of the passions, and can never pretend to any other office than to serve and obey them. ${ }^{61}$

Reason here is not the driving force; it is, as I have heard some call it, 'a gun for hire'. For Hume, what we desire, and also what we possess an aversion to, is the basis of all ethical choice and assessment. This does not mean that we are amoral - employing reason to dominate others in a tyranny of unchecked desire. Hume's notion of 'the passions' includes sympathy, the basis of ethics in his assessment. Hume does see our view of the good, though, as caught up closely with our desiring:

Desire arises from good consider'd simply, and Aversion is deriv'd from evil. The Will exerts itself, when either the good or the absence of the evil may be attain'd by any action of the mind or body. ${ }^{62}$

That which we desire, we call good. That which we recoil from, we call evil. This begins to clearly differ from Buddhist and Aristotelian analyses of desiring and morality, but it makes clear Hume's place as a dissenter. ${ }^{63}$ Such an approach is of course partly replicated in the work of Utilitarians such as John Stuart Mill. While an analysis of the Utilitarian conflation of the ethical and the desired (as opposed to the desirable $\mathrm{e}^{64}$ ) is beyond the limits of the current work, it is worth noting the robust attack on this position made by G. E. Moore in his Principia Ethica. ${ }^{65}$

\section{Schopenhauer: the will and the world}

One of the key Western writers to address desire, and one of the first to do so with reference to Indian philosophy, is Arthur Schopenhauer in his mammoth The World as Will and Representation. ${ }^{66} \mathrm{He}$ is clear in his view that all 'Willing ${ }^{67}$ - a category arguably broader even that just 'desire' - is based on 'lack':

All willing [original italics] springs from lack, from deficiency, and thus from suffering. ${ }^{68}$ Fulfilment brings this to an end; yet for one wish that is fulfilled there remain at least ten that are denied. ${ }^{69}$

He goes on in this vein, seeking to demonstrate the futility of willing/desire - a theme we will return to with Schopenhauer and beyond. Schopenhauer sees desire as what we might call a tragic force - a force in need of negation or annulment. Schopenhauer is no longer a fashionable thinker. So, why engage with his ideas? 
First, he unquestionably has something to say about the nature of the human 'Will'. Indeed it might be argued that he has so much to say (in The World as Will and Representation particularly, but also elsewhere in his work) that people are a little reluctant to engage with him, and tend to opt for brief summaries of his thought.

The second, and decisive, reason for the extent I examine his thought here is his explicit acknowledgement of sources from Indian thought - most particularly Buddhism and Hinduism. ${ }^{70}$ The model of Willing - and desiring - constructed by Schopenhauer is based on an essentially Hindu approach, albeit one influenced in many ways by a Kantian stance. Rather than posit Appearance and The Forms as Plato does, Schopenhauer prefers the notion of Māya. The Monier-Williams Sanskrit-English Dictionary has a lot to say about $m \bar{a} y \bar{a}$, ranging from its more ancient usage as 'art, wisdom, extraordinary or supernatural power ${ }^{71}$ to the more common interpretation. That is, $m \bar{a} y \bar{a}$ is a way of talking about the world, at least as we are able to interact with it without religious progress, as illusory and unreal:

(in phil.) Illusion (identified in the Sāmkyha with Prakriti or Pradhāna and in that system, as well as in the Vedānta, regarded as the source of the visible universe).$^{72}$

In Schopenhauer's take on $m \bar{a} y \bar{a}$, he rehearses the traditional idea of life as dream. ${ }^{73}$ He makes a connection, in this regard, with Plato: ${ }^{74}$

The Vedas and Puranas know no better simile for the whole knowledge of the actual world, called by them the web of $M \bar{a} y \bar{a}$, than the dream, and they use none more frequently. Plato often says that men live only in the dream; only the philosopher strives to be awake. ${ }^{75}$

But Schopenhauer moves away from a Platonic approach with his world-view. Not only is our knowledge of the phenomenal world illusory (for Plato, only Knowledge of the Forms being 'real'), but the world itself is $m \bar{a} y \bar{a}$ :

Here Schopenhauer goes beyond both Kant and Plato, and borrows his model from Eastern philosophy; the world of appearance is an illusion (albeit a 'necessary' illusion) and reality is hidden behind the 'veil of maya'. ${ }^{76}$

One might be tempted to argue that his view of māya has to be discussed because it provides the metaphysical backdrop to his writing on the Will, which in itself is seen by him as something of a metaphysical principle.

It is more than that though; his ideas of the Will are inextricably intertwined with his view of the world as experienced. It is the nature of Will that makes things appear to us as they do - all metaphysics is ontology; all reality emerges from the nature of being, which is at its heart the nature of the Will. Like the Vedantist equating ätman and brahman, for Schopenhauer ontology is the unmasker of a grand 
metaphysical scheme. That is, to discover things about the nature of what exists and the nature and status of mundane and ultimate reality, we must not look out to the world. Indeed Schopenhauer does not see science as a means for obtaining knowledge of the world. Writing on Schopenhauer, Solomon describes his approach to science:

Science in particular is not the road to knowledge but rather a reinforcement of just those illusions which give us a false picture of reality. ${ }^{77}$

Rather, to answer these metaphysical questions, we must engage in the science of being, in ontology, and use that as the basis of our thinking and speculation. We must turn inward, and when we do so, what we find is the answers to the world without. When we locate within us the driving force, the root of our actions and beliefs, we discover the will, an individual will. But this will we find is not truly ours, for it exists only as a form, expression or manifestation of the universal Will. What distinguishes individual willing from the universal Will is that only the former has a specific goal in its sights: ${ }^{78}$

Every individual act has a purpose or end; willing as a whole has no end in view. ${ }^{79}$

We shall see this notion reoccur later in this chapter. Schopenhauer repeats the point ${ }^{80}$ later in the text, adding that the two are ultimately the same, and that we only need to learn to realise it. This makes him sound even more like a Vedantist. Despite its seeming difference from will-as-we-experience-it, and unlike the Noumenal for Kant, we can know the Will through reflection and introspection. Ontology becomes a coherent metaphysics by this means.

We might claim that Schopenhauer's view is rather like that of Vedānta - but where something akin to tanhā takes the role played in Hindu thought by àtmanbrahman. Schopenhauer offers no positive evaluation of the Will, as Hinduism does of atman-brahman, and we might see some of the views of tanha as a metaphysical principle (which are discussed in Chapter 3) as close cousins of Schopenhauer's position.

If we cede to Schopenhauer the existence of this Will, what does that say about the world as we have hitherto experienced it, as a physical phenomenon felt through the body? If we start with the body we can see how Schopenhauer builds up a picture of the Will as the world. The key here is that the body is the Will. As Solomon puts it:

one's body is something more than an appearance in the phenomenal world: it is the Will objectified, not a phenomenal object. This is the key to Schopenhauer's philosophy. He then generalizes this observation to apply to the world as a whole, which is also a manifestation or objectification of the Will. ${ }^{81}$ 
Schopenhauer is allegedly proposing a world-creating role for the Will, although this is not to be taken as a positive thing. Schopenhauer expresses this in the notion that the world is the Will, as perceived through the process of representation. He makes the connection between the body and the Will patently clear in one of the very, very few passages in The World as Will and Representation that made me laugh:

For intellect and brain are one; and in just the same way, the genital system is one with the most vehement of all desires. I have therefore called this the focus of the will. Just because the terrible activity of this system still slumbers, while that of the brain already has full briskness, childhood is the time of innocence and happiness, the paradise of life, the lost Eden on which we look back longingly through the whole remaining course of our lives. ${ }^{82}$

I quote the whole section here not only to show the body as expression of will - even in a manner Schopenhauer clearly finds a little distasteful - but also as the time of childhood almost looks free from the Will; can this make sense? For Schopenhauer however, we are not free in childhood - but the foreshadowing wanting of childhood is nothing to the full blast of the Will we feel as adults. While Schopenhauer could say it more explicitly, it is not difficult to connect this with his view of the terrible-ness of the desires associated with the genitals! ${ }^{83}$

The Will then has much to answer for. As maker of our world it is the force. Individual humans and animals die and are born, but the Will moves on. This might remind one of recent debates regarding genetic determinism, and Schopenhauer does begin to sound a little like Richard Dawkins in The Selfish Gene, albeit with the Will as that seeking its purpose in continuation: ${ }^{84}$

This metaphysical desire of the will-in-itself has primarily no other sphere of action in the series of beings than the hearts of the future parents. ${ }^{85}$

When reproduction is prevented, it is for Schopenhauer a metaphysical occurrence:

The passion is extinguished also when, through the woman's eventual barrenness, the real metaphysical purpose is frustrated, just as happens daily in millions of seeds trampled under foot. Yet in these seeds the same metaphysical life-principle strives for existence, and there is no other consolation for this than the fact that an infinity of space, time, and matter, and consequently an inexhaustible opportunity for return, stand open to the will-to-live. ${ }^{86}$

The Will may be frustrated in the short term, but in the end, it will not be denied. What are we to do then? Buffeted by the Will, struggling to resist the very force that is the basis of the world and even our body, surely we are doomed to pessimism and 
misery. We may obtain some respite from the Will though, as Alasdair MacIntyre notes on Schopenhauer:

In a moment of compassion we extinguish self-will. We cease to strive for our own existence; we are relieved from the burden of individuality and we cease to be the plaything of Will. The same relief is granted to us in the contemplation of works of art. $^{87}$

Ethical and aesthetic experience can provide a partial relief; they subvert the Will. But this subversion is temporary and difficult. We know how hard it can be to put others before oneself, and Schopenhauer does seem to admire those elements of religion that would encourage us to do so. Aesthetic appreciation is finite. During it we may be, literally if we take seriously what Schopenhauer says about the Will as world-maker, beyond space and time and the other formations of the Will, but we cannot remain lost in this artistic rapture forever. And once we cease, the Will rushes back, as forceful and unceaseless as ever. ${ }^{88}$ Does Schopenhauer offer us any other reprieve? Yes - but it is one that is unlikely to cheer the reader, as Solomon remarks:

The only durable escape from the Will, however, is through philosophy. In philosophy one gives up (or ought to give up) the false optimism that everything happens for a purpose, that life is essentially good, that happiness is, after all, possible (this is why, in addition to sheer envy and competitiveness, Schopenhauer so despised Hegel). The truth is rather that of the Upanishads: life is suffering. ${ }^{89}$

The other route to deny the Will that Schopenhauer recognises is that of ascetics, celibates and saints of some sorts, whom Schopenhauer saw as managing to fully deny the Will - putting an end to the world as Will. Whether or not Solomon is correct regarding the message of the Upanisads can wait till Chapter 2, but if we look to the way that philosophy is a solution to the Will we find it expressed negatively. Indeed, the solution is a denial of the Will. In the conclusion to the first volume, ${ }^{90}$ Schopenhauer admits that his only answer is negative:

We, however, who consistently occupy the standpoint of philosophy, must be satisfied here with negative knowledge, content to have reached the final landmark of the positive. If, therefore, we have recognized the inner nature of the world as will, and have seen in all its phenomena only the objectivity of the will; and if we have followed these from the unconscious impulse of obscure natural forces up to the most conscious of man, we shall by no means evade the consequence that, with the free denial, the surrender, of the will, all those phenomena also are now abolished. ${ }^{91}$ 
Here Schopenhauer is alerting us to the consequences of such a denial - of the need to relinquish, possibly, our attachment to the world. For the world as we experience it is an objectification of that which enslaves us and drives us to suffernot something to be clung to and desired. We can make a clear comparison here to Buddhist notions of craving, but in a way that foreshadows some of the challenges faced in Chapter 3. Schopenhauer makes this Will a metaphysical principle. In general tanhā is not seen as such a principle, but we shall see some in Chapter 3 proposing such a view of $\tanh \bar{a}$ - as a metaphysical notion that acts so as to be the constructer of our lived experience.

Indeed, the echoes of Indian philosophical thought are clear here, as Schopenhauer moves on to show that our resistance to such ideas is the Will defending itself. The final offering of Schopenhauer is a negation, a dissolving into what we might describe as 'emptiness' - although 'nothingness' might be more in line with Western philosophical nomenclature, this idea does have parallels with Mahāyāna notions of Śunyatā. This denial of will, this letting-go, leads to the end of the world as we know it:

Subject and object; all these are abolished with the will. No will: no representation, no world. ${ }^{92}$

Before us there is certainly left only nothing; but that which struggles against this flowing away into nothing, namely our nature, is indeed just the will-to-live which we ourselves are, just as it is our world. That we abhor nothingness so much is simply another way of saying that we will life so much, and that we are nothing but this will and know nothing but it alone. ${ }^{93}$

Finally Schopenhauer disappoints, for his solution to this world of futile willing and suffering seems like rather a thin-soup answer, lacking the substance and force of his diagnostic arguments. We may be able to subvert the will temporarily via art and philosophy - but not for long. There may be a possibility of a permanent denial - through asceticism; but even this offers only the prospect of a worldending solution - no wonder Nietzsche ultimately sees Schopenhauer amongst the hosts of the 'world-denying'.

\section{Nietzsche to Deleuze: desire, will and power}

In a number of thinkers we see desire as dynamic - as something on the move:

Desire is movement, be it in Freud's drives, Nietzschean forces, in Reich's analysis of the buried hopes that chose fascism or in Deleuze and Guttari's sense of production. ${ }^{94}$

Here we can see desire as active, and in more contemporary Western thought we see this alongside a rejection of characterising desire as 'lack'. Nietzsche seems although it is not always totally clear - not to see desire as absence and lack; rather 
he sees it as creative - as force. Alan Schrift claims that:

The link between desire and creativity appears frequently in Nietzsche's texts. $^{95}$

Of course, Nietzsche is more associated with ideas of 'will' than explicitly 'desire', but I have argued that they are closely related. Given that willing is closely connected with wanting, as discussed in the Introduction, we can clearly see the notion of the Will-to-Power as the (ideal) basis of human action. Even when it is sublimated, such as in the Will-to-Nothingness, ${ }^{96}$ it is still an active willing. The Will-to-Nothingness is a desire that seeks its own destruction; now where have we heard that before?

We can, then, see Nietzsche reading desire as creative. A reading of the Willto-Power as a reversal or attack on desire as lack is encountered most explicitly in the otherwise rather opaque writing of Gilles Deleuze. Deleuze shares a response to the view we have seen of desire as lack with many of his contemporaries:

There is no concept that incurs greater wrath among contemporary theorists of desire than that of lack. ${ }^{97}$

Indeed, Deleuze's disdain for the idea of desire as 'lack' almost manages to out-disdain Nietzsche:

Desire: who except Priests would want to call it 'lack'? ... Those who link desire to lack, the long column of crooners of castration, clearly indicate a long resentment, like an interminable bad conscience. ${ }^{98}$

Deleuze's recognition of desire as force, as affirmation, as power is described in ways that evoke both a Nietzschean feel and the grand tone of the Vedas:

There isn't a desire for power; it is power itself that is desire. Not a desire-lack, but desire as plenitude. ${ }^{99}$

Here he sees desire not as an attempt to obtain power, but as an expression of power. It is power seeking a channel, hence its association with plenitude. This seems to revisit Nietzschean notions of the noble man acting ethically towards others not out of pity, but out of a 'superfluity of power'. ${ }^{100}$

Furthermore, this idea is advanced by Deleuze in a way that claims any lack in desiring is not lack of the object, but lack of a subject. ${ }^{101}$ That the lack lies within seems to indicate the reoccurrence of Continental thought's concern with the nature of the Self. We can see this Self as represented by absence - an absence we seek to fill through the objects of desire. The similarities with Buddhist notions of anatta are striking, and this will be returned to later. So, we can see the absence in desiring as the absence of Self - as Sartre has it: 'Nothingness lies coiled in the heart of being - like a worm. ${ }^{102}$ 
Here Sartre encapsulates this idea of our true nature, as lacking, as at base level nothingness, as something lurking within us, almost malignant. We might speculate that mistaking the absence within for an absence without is the base root of desiring. ${ }^{103}$ This is an externalising of our own 'nothingness', but also might be seen as related to the notion of ignorance. It evokes Hindu ideas whereby our suffering is often seen as arising from ignorance of our true nature - albeit the permanent àtman in that case (where we think we lack something that we already have).

The absence may be felt as though external - but are we not then sublimating our own nature as Self-lacking when we desire external objects of desire? Perhaps desire for external objects is the means by which we seek to deny our lack of a coherent subject.

Might we be creators of the I/World duality through the very act of desiring? Is it our reaching out to find another means of representing this lack that gives rise to the subject/object distinction - where we are able to view things beyond the Self from an illusion of Self-hood?

We might consider this as rather Buddhist-sounding. Could we liken a sublimated Will - even the Schopenhauerian form of it - to the vibhava-tanha of the Second Noble Truth ${ }^{104}$ I think we might - perhaps the closest notion is that of Nietzsche's Will-to-Nothingness, a Self-destructive drive, or a desire to escape the inevitability of Being.

In his entry on Deleuze, John Lechte summarises Deleuze's approach to desire:

We have seen that desire is not a desire based on lack - which is negative but is always in movement and reforming itself: it is an affirmative process of flows and lines of flight. ${ }^{105}$

The denial of lack here is the lack of the object, and does not seem to affect his comments on the nature of Self. Maybe like Deleuze and Nietzsche ${ }^{106}$ we can see desire as more than lack, but as creative. Of course, such a Will has the potential to be destructive as well, but this does not preclude its creative potential. Desire has been discussed in the context of the Will-to-Power. ${ }^{107}$ Looking at Nietzsche's Will-to-Power and the manner it can be understood as being related to desire, Michael Stoeber (through a comparison with Dostoevsky's The Brothers Karamazov) sees clearly the creative element in desiring. He begins with the thought of Jacob Boehme, who refers to will as a 'self-fuelled fire'108 - a phrase with many echoes to Buddhist ears. As will be demonstrated in Chapter 3, there is no doubt that desire, at least in some forms, is Self-perpetuating - it is seen as a result of desiring that we exist at all, given that the elimination of tanhā is often equated with the elimination of dukkha and therefore the attainment of nibbanna. ${ }^{109}$ Or inversely, it is desire that chains us to the wheel of rebirth. Boehme, via the work of Friedrich von Schelling, is believed to have had some influence on Nietzsche's account of the will. ${ }^{110}$ In this account, willing - linked 
to desire - is a deeply creative and pro-active, rather than reactive, act/state:

This primary ungrounded will-spirit is ever seeking a ground in the objects of its imagination. To put it bluntly, it becomes what it wants. ${ }^{111}$ Its freedom lies in the point of desire from which imagination arises and seeks to fulfil itself. ${ }^{112}$

Desire is cast here as almost an internal uprising, an upsurge of power seeking an object. Or as Stoeber puts it a little further into his discussion: 'The goal is what the will makes of its power.' ${ }^{113}$ Like, as we shall see, some Indian thinkers, Stoeber, in his reading of Nietzsche, sees the creative aspect of willing:

The nature of becoming is determined by this primary and self-justified commanding of the will. ${ }^{114}$

While we do find a concern with 'willing' in The Brothers Karamazov, it is to Dostoyevsky's tragi-comic masterpiece Notes from the Underground that we must turn to see desires run amok as a cautionary tale. While the concerns of this book prevent too much of a digression on it, there is something haunting and terrible about the image conjured by 'that hell of unsatisfied desires turned inward'. ${ }^{115}$

Of course, Nietzsche's view of the nature of desire is one with historical antecedents - as we saw. ${ }^{116}$ Indeed it has to be seen in the context of his response to Greek thought. In response to Plato's Republic Nietzsche questions the primacy of reason over desire:

For Nietzsche, a principal source of tyranny is the platonic conviction that of the three sources of human motivation (reason, will and the appetites) reason should dominate. ${ }^{117}$

Here we can clearly see a concern with the hierarchy of motivation established by Plato. It is also interesting to note that what others translate as 'spirit', Goodheart gives as 'will'. I do not treat desire as purely 'appetite', and so might consider 'will/spirit' to also contain part of what I indicate when I discuss desire in this context. This is another debate touched upon by the protagonist of Notes from the Underground:

You see, Gentlemen, reason is an excellent thing, there's no disputing that, but reason is nothing but reason and satisfies only the rational side of man's nature, while will is a manifestation of the whole life. ${ }^{118}$

To privilege reason over other aspects of motivation is seen as to only partially understand what it means to be human. Clearly to invert the hierarchy may be equally problematic, and while the anti-hero of Notes from the Underground seems in danger of this, Eugene Goodheart sees Dostoyevsky's character as opposing the opposition 
between the two, rather than seeking to place 'will' in the place of 'reason':

In Notes from the Underground, the protagonist argues for desire against reason or, more accurately, against the opposition between desire and reason in which reason asserts its superiority. ${ }^{119}$

In assessing the relations of desire and reason, what Goodheart calls a 'dialectic of desire', ${ }^{120}$ the anti-hero of Notes from the Underground sees desire as part of the escape from the tyranny of reason. It is not so much a wish to subvert reason to the rule of the 'passions', as Hume seems to have recommended, but to dispute the notion that the two are bi-polar opposites. In true post-modern style, Dostoyevsky stands against the notion of binary oppositions. ${ }^{121}$

Furthermore, we might see here the wish to use desire, rhetorically and philosophically, as a strategy in combating overly mechanistic views of human nature. This has echoes of Aristotle's notions of harmony over an integrated person which promotes the virtues - although such virtues may not exactly match those that Nietzsche would have us adopt.

In seeking to liberate humanity from the reduction of life, and in particular morality, to calculation and some kind of reductionism, desire can play a key role:

In rebellion against a despotic utilitarian reason that deprives the individual of his personal identity, in effect reducing him to a 'cipher, a statistic,' an instance of the laws of nature, the underground man affirms the authenticity and freedom of being through desire. ${ }^{122}$

Nietzsche's approach to the notion of 'Will' must, of course, be placed in the context of his response to Schopenhauer. While he found much early inspiration in his writings, Nietzsche sees Schopenhauer as falling into the trap of viewing desire as something to be denied. He sees Schopenhauer's work as:

A mendacious attempt of genius to marshal, in aid of a nihilistic total devaluation of life, the very counter-instances, the great self-affirmations of the 'will to live', the exuberant forms of life. ${ }^{123}$

He goes on to accuse him of this with respect to arenas of endeavour such as art and beauty, as well as sympathy. This is the greatest possible condemnation from Nietzsche - that something is life-denying is worse than calling it false. ${ }^{124} \mathrm{He}$ goes on to further damn Schopenhauer by likening his thought to Christianity:

the thirst to deny the 'will' - the greatest piece of psychological falsecoinage in history, Christianity alone excepted. Looked at more closely he is in this merely the heir of the Christian interpretation. ${ }^{125}$

Indeed Nietzsche believes, rightly I tend to think, that Schopenhauer makes a fundamental error when discussing 'will'. Indeed his claim is extended to 
philosophers in general, and in a sense is part of the rationale for this endeavour:

Philosophers are accustomed to speak of the will as though it were the best-known thing in the world; indeed Schopenhauer has given us to understand that the will alone is really known to us...

...Willing - seems to me to be above all something complicated, something that is a unity only in name. ${ }^{126}$

He goes on to elaborate, discussing a dynamic of willing, leading to the conclusion:

a philosopher should claim the right to include willing-as-such within the sphere of morals - regarded as the doctrine of the relations of supremacy under which the phenomenon of 'life' manifests itself. ${ }^{127}$

Here willing seems to come closer to the way desire is often discussed, as moral although Nietzsche is more likely to be indicating that it is requiring of moral assessment, rather than its being moral in itself. ${ }^{128}$ Elsewhere Nietzsche seems to move willing and desire apart somewhat. However, what is most significant here is that allowing for a complexity of will seems to also leave Nietzsche able to recognize the complexity of desire - and assert that some desires are not the same as will. As mentioned in the introduction, Will may be the resisting of desire - and at times in conflict with it; although of course, desires themselves are often in conflict with each other as well. This means that Nietzsche sometimes is rather ambiguous in his assessment of desire. At one point he wishes to cast it in a negative role:

The immoralist speaks. - Nothing offends a philosopher's taste more than man when he expresses desires...the philosopher despises desiring man, and the 'desirable' man too - he despises all the desiderata, all the ideals of man. ${ }^{129}$

His account here seems to see desire in a sense as different from will, in that 'desire' here is a retreat from doing:

How does it come about that man, so admirable as a reality, deserves no respect when he expresses desires? Does he have to atone for being so able as a reality? Does he have to compensate for his activity, for the exertion of will and hand involved in all activity, with relaxation in the imaginary and absurd? ${ }^{130}$

The type of desire Nietzsche refers to here is a non-willing desire. In some senses this might be taken as a reference to 'longing', to that range of desires we possess for the non-immediate future. It may be that the religious yearning-type of desire that much religion is able to accept as a tolerable form of desire, is a form of desire that Nietzsche wishes to exclude from his positive (re)evaluation of 
willing (and to an extent desire). In that light perhaps his comments should not surprise us.

A key thing to take from what has been said here, particularly with relation to Deleuze and Nietzsche, is that desire - in the form we encounter it as an element of our lived experience - is constructed. As William Bogard notes in an on-line posting, which also captures the context in which desire is often discussed in Continental thought:

Class distinction (bifurcation) is also hooked up with the problem of desire in capitalist economies (how desires are produced, restricted, channelled, condensed). Veblen, certainly, recognized this. This was also the focus of 'poststructuralist' philosopher Gilles Deleuze in his book Anti-Oedipus (with Felix Guattari). ${ }^{131}$

I end this section by turning, albeit briefly (for it is primarily used in a political sense beyond my current remit), to an idea that seems to evoke certain Buddhist ideas. In some writing by Deleuze he uses the term 'desiring machines', by which he seeks to represent the intensely intertwined nature of desire and human-ness. Referring to Deleuze's view of Nietzsche's Will-to-Power, Brian Massumi writes:

In Anti-Oedipus, a tendency of this kind was called a 'desiring machine'. Due to persistent subjectivist misunderstandings, in A Thousand Plateaus the word was changed to the more neutral 'assemblage'. ${ }^{132}$

This notion of an 'assemblage' - with the idea of a 'desiring-machine' related to it - may indeed make us think of the Buddhist notion of a person as consisting of 'the aggregates' - and with the role of desire in Buddhist thought this seems reinforced. Clearly the political senses that Deleuze relates to desire are absent from Buddhist thought, but we can see the resonances between the two.

This notion of 'desiring machines' not only may seem to fit with a 'causal process' view of the nature of humans (or indeed, 'sentient beings'), but relates to this notion of desire as a reaching out into the world - an affirmation far from the idea of 'lack'. John Landau seeks to clarify Deleuze's notion, with some success:

To speak of 'desiring machines' or 'desiring contraptions' is to understand subjectivity in terms of these sorts of interlocking fields or circuits of couplings. We cannot be confined to the bag of skin which is 'our' body's exterior. Who we are is a circuit of couplings - this implicates us in the world and in each other. Thus desire is always social and always geared towards an active expression or reaching-out-ness, not out of lack but out of affirmative forcefulness and urge to contact. ${ }^{133}$

This gives us a much clearer sense of the rejection of desire as 'lack', and reinforces the notion of desire as a creative out-reaching. Further to this, Deleuze's view of 
desire, while seeing instances of it as caught up in a complexity of relations, does see desire in itself as a power which underlies mundane existence. We shall see much more of this in the Hindu views in Chapter 2, but Dorothea Olkowski sees this clearly in Judith Butler's reading of Deleuze:

The absence of specific social and historical conditions qualifying Deleuze's conception of desire leads Butler to conclude that desire is an 'ontological invariant', 'a universal ontological truth' that Deleuze has managed to release from an interminable period of suppression. ${ }^{134}$

Olkowski identifies this suppression as originating in Plato's Symposium, where it is seen as a sign of, but not the content of, our " "ontic" incompleteness'. 135 There is no doubt that Deleuze breaks with this view of desire as 'lack', but whether he goes as far as Butler seems to suggest is questionable. Yes, he grants power unto desire, but is unclear whether he could be fairly characterised as suggesting it as a formal ground of being; a metaphysical or cosmic principle of origination seems a step too far for his view. We will see such a view, but will have to wait till the Chapter 2 (and travel back to the time of the Vedas) to do so.

\section{Hegel and Butler}

One of the most lively theorists currently working on the notion of desire is Judith Butler. Her work on desire draws primarily on Hegel, which is why I consider Hegel here a little out of turn (his death being thirteen years before the birth of Nietzsche).

Hegel draws heavily on Western philosophical tradition, viewing desire as closely related to lack. Showing also Hegel's affinity with Spinoza, Butler indicates Hegel's view of the nature of desire:

For Spinoza and Hegel, the metaphysical place of the human subject is articulated through the immanent rationality of desire, for desire is at once the fundamental striving of the human subject and the mode through which that subject rediscovers or constitutes its necessary metaphysical place. ${ }^{136}$

Hegel's placing of desire in this metaphysical location, and the connection with lack, places him outside the counter-tradition that we have seen in the section above. Furthermore the optimistic tone of Hegel finds few takers amongst contemporary theoretical discourse:

The criticisms waged against Hegel by Lacan insist upon the psychoanalytic inevitability of dissatisfaction, while Deleuze and Foucault, through recourse to Nietzsche, take issue with the entire Hegelian emphasis on negativity and offer a version of desire based on excess and plenitude rather than lack. ${ }^{137}$ 
Nonetheless, Butler wishes to defend Hegelianism, and Hegel does say a certain amount about desire in his Phenomenology of Spirit.

This discussion mainly occurs in section IV, The Truth of Self Certainty, and while this is a reading deeply entrenched in the technical vocabulary of his style, he makes some startling claims. He does identify desire with self-consciousness, fundamental to our mental make-up; indeed he goes as far as to write that 'self-consciousness is Desire'. ${ }^{138}$ This is not the whole view though, for desire is closely related to the notion of the 'Other'.

Desire is what directs us toward the other - initially as an object of desire, for us, rather than as another human subject - but is also what makes us aware of the other as something which is more than an object of experience, but which is also a subject, a for-itself. After just such an analysis, Hegel intentionally reinforces this point by knowingly contradicting the statement above:

It is in fact something other than self-consciousness that is the essence of Desire. ${ }^{139}$

This may seem paradoxical, but makes sense when we see desire in the context of Hegel's overall view of self-consciousness:

Self-consciousness exists in and for itself when, and by the fact that, it so exists for another; that is, it exists only in being acknowledged. ${ }^{140}$

Desire here is the way self-consciousness becomes aware of itself, and the story of human completion is through the realisation of its relation to others. This seems captured by a brief line from Pasternak: '... everything in the world must excel itself to be itself'. ${ }^{141}$

\section{Sartre - desire and nothingness}

Man is a useless Passion. ${ }^{142}$

I will come back to Jean-Paul Sartre in the concluding chapter, but wish to briefly address his most direct engagement with the notion of desire. Most explicit is his comment that 'fundamentally man is the desire to be'. ${ }^{143}$

Sartre, as we must surely expect, does not see a completion of this 'being' though. I have mentioned previously the idea that actual, individual desires emanate from some more fundamental general form of desire, be this the sublimation of sexual desire, or the blind striving of the flailing Will of Schopenhauer. Butler describes this when she discusses the:

Sartrian contention that all human desire is a function of the desire to become God. But for Sartre, this desire is bound to fail. ${ }^{144}$ 
Desire here is insatiable, it will never - in the atheistic world-view of Sartrean existentialism - find fulfilment. But were it to do so, this too, from Sartre's perspective, would be in itself a tragedy for it would signal the end of life itself. This is clear when Butler describes Sartre's view of desire:

It is the entirety of our spontaneous selves, the 'outburst' that we are, the upsurge that draws us toward the world and makes the world our object, the intentionality of the self. ${ }^{145}$

While we may inhabit a world of contingent reality, burdened by freedom, Sartre sees desire as a vitality amongst this - even if it is condemned to fade and pass.

\section{The purification of desire: Theosophy}

A brief word now on a group as close in theory to the Chapter 2 as this one, if geographically and culturally located in this chapter - Theosophy. Theosophy, as characterized by Helena Blavatsky and Colonel H. S. Olcott's 'Theosophical Society', ${ }^{146}$ is a self-consciously constructed form of religious and philosophical thought. A fair description of it can be found in A Dictionary of Philosophy, where it is characterized as having doctrines that 'are a blend of Hindu and Neo-platonic elements'. ${ }^{147}$ I think it is fair to say that its initial purpose was:

To derive from ancient wisdom and from the insights of evolution a world ethical code. ${ }^{148}$

Whether this goal was achieved I leave for others to judge, but I invoke their name here because of their interest in desire. A common approach of Theosophists is to claim that desire - as normally experienced - is a lower form of a Divine or universal Will - leading to the need to 'purify' desire:

Will is the exclusive possession of man on this our plane of consciousness. It divides him from the brute in whom instinctive desire only is active.

Desire, in its widest application, is the one creative force in the Universe. In this sense it is indistinguishable from Will; but we men never know desire under this form while we remain only men. Therefore Will and Desire are here considered as opposed.

Thus Will is the offspring of the Divine, the God in man; Desire the motive power of the animal life.

Most of men live in and by desire, mistaking it for will. But he who would achieve must separate will from desire, and make his will the ruler; for desire is unstable and ever changing, while will is steady and constant.

Both will and desire are absolute creators, forming the man himself and his surroundings. But will creates intelligently - desire blindly and 
unconsciously. The man, therefore, makes himself in the image of his desires, unless he creates himself in the likeness of the Divine, through his will, the child of the light.

His task is twofold: to awaken the will, to strengthen it by use and conquest, to make it absolute ruler within his body; and, parallel with this, to purify desire.

Knowledge and will are the tools for the accomplishment of this purification. ${ }^{149}$

We see here a mixture of some of the things I have been discussing. Desire and Will undergo a qualitative separation. We also see the acknowledgement of desire as a creative force - if a morally ambiguous one. ${ }^{150}$ Indeed it is this point that is the most important here; foreshadowed in this chapter, but coming into its own in the next when we assess desire in Vedic thought.

\section{Mind-made desires}

In Chapter 4, I will consider the extent, from a Buddhist perspective, to which our desires are not a reaction to sensory stimuli, to sense data, but rather are 'mindmade' - the projection into the world of our own consciousness. Not all the writers we have seen here though would ascribe to this view, and there are other ways in which desire is seen as being constructed.

The forms of desire may well be socially constructed; that is, the manner in which desire expresses itself, what it takes as object. We began to look at this with Deleuze, but beyond that might we not even see the very nature of the desires themselves - their type and their object as so constructed? If so, this undermines the notion that desire arises from the body, and possibly even from the mind, unless we see the mind as acting as part of these socio-cultural relations.

Might there be wholly culturally-constructed desires (although we often take them to be universal aspects of some shared human nature)? Probably the best example of this is romantic 'love'. In Love in the Western World Denis de Rougement argues that if people had not heard of this notion of 'love' they would not actually 'fall in love'. The representation of desire in a new way allows, maybe even causes:

neglected potentialities of the heart suddenly to become profusely actualized. ${ }^{151}$

This seems altogether possible, especially if we are able to step back a little from the Western fetishisation of the notion of romantic love, and more recently of sexual desire. Both of these oft-intertwined ${ }^{152}$ desires or drives may have a physiological element as root factor, but their form and expression is constructed by numerous factors. This may give a sense of how our lived experience, particularly of desire, is partly constructed by the concepts present within us. Some of those whose views I have examined in this chapter may have hinted at this, but 
we shall see in Buddhist texts, especially in the context of paticca-samuppāda, a more sophisticated account of the arising of wanting.

One issue raised by this discussion is the extent to which these ideas posit that culture wholly constructs desire, or acts as a channelling mechanism. That is, is there some desire, like the Schopenhauerian Will, which then becomes channelled onto various foci? Or can we go further, suggesting that desire comes solely from cultural contexts - that it can be seen as purely the sum of arising from particularist interactions? Such a view clearly goes against the view of many discussed here.

Whether or not we can find connections between this and the Buddhist view will depend on how we come to view that nature of desire in Buddhism. As indicated, we shall see some in Chapter 3 who would raise tanh $\bar{a}$ to such a level that it expressly opposes such a contention.

\section{Conclusion}

I must take the long journey to Athens, city of learning: May the length of the way set me free from love's oppression. My passion grows when I constantly gaze at my loved one; It is love itself that nourishes love. ${ }^{153}$

Much of what has been said in this chapter regarding desire undoubtedly casts it as a villain. Desire drives our vanity; the Will is, to Thomas Mann writing on Schopenhauer:

A fundamental unhappiness, it is unrest, a striving for something - it is want, cravings, avidity, demand, and a world of will can be nothing but a world of suffering. ${ }^{154}$

For others the will is in constant tension with reason - no matter which of them one thinks should be the ruler in this dialectic dispute, and there are others again who take issue with the whole notion of opposing the two ${ }^{155}$ in this manner, from Aristotle to Deleuze. There is more of this to come. In Chapter 2 we will see a tradition turn on desire, but the Vedic approach is - like much of what we have seen here - testament to the complexity of desire as a psychological and, in the Upanisads, an ethical phenomenon. Furthermore, the role of reason has sometimes been contrasted with desire, and we shall, In Chapter 4, investigate the way Buddhism views reason in its discourse with desire.

Furthermore, we might claim that some of the more interesting responses to desire represent the view that desire can be the bridge to the (re)completion of the human condition through creative imagining. Desire could be seen as something which we use to define ourselves, to make ourselves. This notion of the creative power of desire will be seen expanded to a cosmological level in the Chapter 2.

One of the most useful notions to emerge here is the relation of the Self to desire. When I discussed the lack of a coherent or enduring Self or subject as the 
root of the belief of desire as a lack, the Buddhist echoes became deafening. Kojéve sees our inner lack as driving desire in a way that leads to us seeking to negate or destroy the other - the object of desire:

the I of Desire is an emptiness that receives a real positive content only by negating action that satisfies Desire in destroying, transforming and 'assimilating' the desired non-I. ${ }^{156}$

The obvious connection between this approach and the Buddhist teaching on anatta is further examined in Chapter 5, as is the notion of change, expressed so clearly in the work of Seneca and its relation to anicca.

In Western thought, this link between our desiring and our 'emptiness' clearly comes out of an intellectual period that spawned Sartre and Heidegger. Here while we might argue that desire still arises from 'lack', the lack is not an absence of the apparent object of desire; rather it is the hole at the centre of our being that we would fill. But this lack is irresolvable; emptiness is our nature, ${ }^{157}$ being the basis of our characteristic of negation.

An important issue that has come to the fore in this chapter is the way that desire has been seen as extending beyond our individual wants for specific objects. We have seen notions of Will employed which grant it grand metaphysical significance (we will see this metaphysical tone supplemented, and to an extent replaced, by a cosmological approach in the Chapter 2). We have seen the 'emptiness' of the human subject as the driving force of desire; alongside which desire has often been cited as creative, although in differing ways. One theme that is important here is that desire is a general force, with no specific object; only when it erupts into consciousness does it then, in combination with either our dispositions or cultural forces, begin to be clearly directed at individual objects of desire. $^{158}$

More recently, as we have begun to see, desire has become a more significant focus of Western philosophical discourse. Alongside this is a recognition of its complexity. While mainly concerned with the social production of our desires, Patricia Leavy recognises the occurrence of desire between the subject and object of desire, the complexity in unravelling the factors involved in even a single occurrence of desiring:

The desire for the product or passion does not exist in my body alone, but rather in the relation between the object or subject and myself. In our postmodern context the mediating factors between what is desired and the desirous individual are increasingly manifold yet often invisible. ${ }^{159}$

While she has other fish to fry, the recognition here of desire's complexity is interesting. Furthermore, Leavy claims that desire is a relational event. While this may not wholly coincide with notions of a metaphysical pre-object principle of cosmic desire, it seems to accord with experience. What we want arises out of 
more than just our solipsistic selves; it is a response to our interaction with the world. We shall pick up this notion in Chapter 4, where the paticca-samuppāda process in Buddhism sees desire as arising in response to certain types of stimulation.

I wish to complete this chapter by reviewing some advice that I intend to ignore. In differing from Heidegger's view that our lack of permanent essence is the proper object of desire, ${ }^{160}$ Michael Zimmerman points us in appropriate, if somewhat Wittgensteinian, manner to the Chapter 2:

In the final analysis, I do not believe that what Heidegger described as the nothingness that 'gives' being is the proper 'object' of what may be humankind's ultimate desire. Mystics of various traditions seem to be on the better track. But of that which we cannot speak, we must remain silent. ${ }^{161}$

In the conclusion to the book, I draw on the material in this chapter to offer comparisons with Buddhist and Hindu thought on desire. In doing so, I am particularly interested in some key ideas that have emerged from this chapter. These are: desire understood as absence - of either the object of desire, or the subject of experience (the Self); desire as a creative force; desire's links to death; how desire is viewed in the context of change; and positive and negative evaluations of desire, particularly in ethical contexts. 


\title{
DESIRE IN NON-BUDDHIST INDIAN RELIGION
}

\author{
Birth is scented with death. \\ Youth's Brilliance is shadowed by old age. \\ Contentment is menaced by ambition, \\ calm, by impudent women's amorous looks, \\ virtue by men's malice, \\ woodlands, by serpents, and kings, by villains. \\ Rich treasure is plundered by transience. \\ Is anything spared the threat of eclipse? \\ Youth in its prime is sapped \\ by a hundred plagues of longing. \\ Wherever the bird of wealth alights, \\ misfortunes swarm through open gates. \\ Soon death is sovereign \\ over every helpless creature born. \\ What is fashioned to endure through Capricious fate? ${ }^{1}$
}

\section{Introduction}

In describing Professor Nicholas Lash's piece 'The Purification of Desire', Julius Lipner sets out one of the key questions I wish to examine, and possibly answer, in this chapter:

Granted that the Gita is concerned basically with the ethics of desire, does it recommend the purification of desire or its suppression? Ethically, surely this is a burning question for our times, for its answer will generate not only a particular worldview, but a code of conduct arising from it. The contours of a life based on the 'cleansing of desire' are very different from one based on its 'abolition'.

Two points with regard to this. First, the question posed here (we will look at Lash's answer when we come to look specifically at the Bhagavad Gìtā) is one we 
might apply to much Hindu writing on desire. Indeed, it is a question I ask of the earliest texts as well of those even later than the Gittà. Second, I must concur with Lipner's claim regarding the relevance of such debates. The way an individual - or indeed a society - conceptualises and regards desire is more than an academic concern. Hinduism recognises the dynamic nature of desiring, and from this has offered a variety of strategies for responding to this inner-dynamism.

As yet, we have seen how desire has been dealt with in some strands of Western philosophical thought. While Chapter 1 contained substantial material from the Western canon, desire has rarely been a primary concern in Western thought. Much of what was collected in Chapter 1 was, as noted on page 18, originally an aside. Schopenhauer is remarkable and singular in his concern with the will. However, the nature of the Self, particularly in an epistemological sense as the subject of experience, has long been a concern for Western thinkers, as it has for those from Indian traditions. In the West, concern with the Self has increased vastly in the last three hundred years; so much so that R. C. Solomon's claims for the role of the Self seem reasonable:

The self that becomes the star-performer in modern European philosophy is the transcendental self, or transcendental ego, whose nature and ambitions were unprecedentedly arrogant, presumptuously cosmic, and consequently mysterious. The transcendental self was the self - timeless, universal and in each one of us around the globe and throughout history. Distinguished from our individual idiosyncrasies, this was the self we shared. ${ }^{3}$

Strong words, but they are worth looking at closely. Primarily they show the importance of the Self to European thought, but also show how close to some views in Hindu thought his description of the Self is - timeless, mysterious, and shared. Even odder then, that discussions regarding desire are so central to one discourse, and so marginal in another.

What is notable however with regard to Brahmanic traditions is the manner in which the emergence of debates regarding the Self are shadowed - or perhaps conjoined with - discussions regarding the nature, status, efficacy and ethical aspects of desire. This will be clearly demonstrated in my examination of the Upanisads - arguably the forum where both themes, the Self and desire, come to the fore as primary religious and philosophical issues.

So, why do we find the Self, in the way it is discussed, so intertwined with desire in Indian thought, while Western discourses of the Self see it as considerably less central? This will be followed up in more detail in Chapter 5, but one might argue that the ontology of Selfhood became sophisticated at a very early stage in Indian thought, with desire linked with it from the outset. Furthermore, the Indian thought examined here is religious; it has a salvific telos, whereas 
much of the Western thought examined has been secular. The identification of the Self with God has allowed a legitimisation of speculation regarding the Self, for inner searching is then the search for the divine. Furthermore, the concern with desire in this religious context has allowed, in part, desire to become seen as a hindrance to salvation.

While the Introduction has demonstrated the necessity of examining the views found in this chapter, there is a further point. As well as placing a frame around the Buddhist views we shall see emerge in Chapters 3 and 4, what is demonstrated implicitly throughout this chapter is the centrality of desire to Indian religious thought. ${ }^{4}$ I do not wish to argue that Buddhism is innovative in treating desire in such detail; rather my thesis is that the manner of this treatment is novel. While a proportion of the material examined in this chapter post-dates the Buddhist material I am concerned with, I think it is worth taking a broad look in Hinduism in the same way I look at Western material. Both present ideas which make for an interesting and fruitful interplay with Buddhist thought.

With this in mind, it clearly makes sense to examine the debates and ideas surrounding desire contained within these traditions. Furthermore we have another, arguably stronger, reason for examining these traditions. In recent work on early Buddhism, some have argued that we should seek to understand early Buddhism, and especially the stance and style of the Buddha, in the context of the existing Brahmanical atmosphere. We must surely read the texts of early Buddhism as, at least in part, a response to prevailing Brahmanic thought. ${ }^{5}$

So, it would be wrong to think of Buddhism as being wholly innovative in its concern with the nature of desire and the problems it is seen to lead to. It is clear from looking at pre-Buddhist Indian religion, and in those religious texts emerging outside of Buddhism around the time of the Buddha and in the halfmillennium following, that the religious traditions which later were to evolve into Hinduism also had a significant interest in both the nature and the consequences of desire.

We would not be overstating the case by claiming that desire, in its many guises, is a central theme in most forms of religion emanating from the Indian sub-continent. As we shall see, this is not wholly universal - not before the Upanișads is the discussion explicit and central. In the Veda Samhitās many references are partial, and cloaked in ritual and sacrificial contexts. Nonetheless, we shall see that as Hindu thought developed, desire came racing into the foreground - a location it retains to the present day in much Hindu and Hinduinspired philosophy and religious reflection.

Indeed, Madeleine Biardeau takes the view that Hinduism revolves around $k \bar{a} m a$. The term kāma will be discussed further elsewhere, but it is a common term in Sanskrit, used for desire in general (although sometimes used in a limited sense to refer to exclusively romantic or sexual desire, it can also be used to refer to the object of desire as well). ${ }^{6}$ Desire is seen as central to all action. Indeed, $k \bar{a} m a$ is the basis of all initiated activity, all voluntary motion of the human. 
She draws on the Mahābhārata ${ }^{7}$ as well as Nyāya philosophy $^{8}$ to make the claim that action always derives from the same process:

Invariably the sequence is: knowledge $\rightarrow$ desire $\rightarrow$ inclination to act. There is no action that is not preceded by a desire, and the latter is never the desire to act, but the desire for an object, for a precise result known to be good in itself. 9

This view, to me, does not seem to do justice to the richness of Hindu thought on the matter. In addition to seeming rather rigid, a potential problem with this approach is the assertion that one can only act, and also only desire, with knowledge as a pre-requisite. Does this mean that all desire is based on knowledge? As I demonstrate throughout this chapter, it seems that desire is often problematic because it is based on ignorance. What is notable though is that both of these sources of desire ignorance and knowledge - are cognitive faculties and processes.

Action based on an ignorance or misperception of the true nature of reality is the source of negative karmic results. ${ }^{10}$ This is why the Upanișads - and particularly their Vedāntin interpreters - exhort us to obtain right knowledge. We shall see, later in this chapter, why the notion of action as requiring desire is so problematic. However, what Biardeau says does demonstrate the centrality of thought regarding desire. It sits at the heart of Hindu thought. In rectifying the way humanity is flawed and misguided, desire is a component in need of significant work.

\section{Desire in the Veda Samhitās}

While there is relatively little clear and consistent discussion of desire in explicit terms in the Veda Samhitās, we can find references to it. These see it, as do some later texts, as a creative force. At Rg Veda 10.129.4 we can see this. I found two translations of this verse which seem quite different. First the older version:

In the beginning this (One) evolved, Became ${ }^{11}$ desire $\left[k \bar{a} m a^{12}\right]$, first seed of mind.

Wise seers, searching In their hearts, Found the bond of Being in Not-being. ${ }^{13}$

The second translation of the same verse is:

Desire came upon that one in the beginning;

That was the first seed of mind.

Poets seeking in their heart with wisdom found the bond of existence in non-existence. ${ }^{14}$ 
This is ambiguous - we should not assume that what creates, or maybe divides in this case, is benevolent or wanted. Nonetheless we do here begin to get a sense of the power of desire. We shall see, as we move through this chapter, the notion of desire as implicated in creation emerging at numerous points. What is significant here is the way that desire plays a key role in the cosmological outlook of Hinduism. As Dermot Killingley comments:

kāma is not only part of human experience but a constituent of the cosmos. It is a product of the mind, but mind itself is a cosmic concept, existing prior to the individual. In the Vedic cosmogonies, the question of what caused the primordial desire does not arise; like the big bang of modern cosmology, the primal impulse is beyond time and causation, so it makes no sense to ask what preceded it or caused it. ${ }^{15}$

Desire then forms part of the fabric of the universe; no wonder we see it as a theme running through Hindu philosophy, from the Vedas to the present day. Returning to this notion of desire as part of creation, it is clear that desire as creative is desire as power. No matter which of the models of desire presented here we look at, it is always a thing of some power.

If we are told to end desire, it is because of what desire can do to us if we do not. Misdirected or unchecked desire is like a wild beast out of control. Some may feel they may tame the beast for their own ends; others may wish to kill it, or drive it away; others may have the bravery to try and ride the beast - to use it as a vehicle to some worthwhile goal; but all recognise the power and danger involved. This image of killing, riding and taming will be returned to later.

Another notable feature of this passage is the movement from the unitary to multiplicity. As Killingley writes:

This text [ $\operatorname{Rg}$ Veda 10.129] might be claimed as the earliest appearance of the production of the many from the one, except that the dating of Vedic texts is so uncertain that such a claim would be merely speculative. ${ }^{16}$

Here we see that desire is, in cosmological terms, the cause of differentiation. This is worth bearing in mind when we look at how overcoming desire is one of the key ways of describing the path back, for the individual, to unity with the divine brahman.

Desire is, then, a force of creative power. We can see this again at Satapatha Brāhmana 11.1.6.1, where the waters wish to procreate. As Killingley remarks:

The name given to the original being varies, but the creative process is still initiated by desire. ${ }^{17}$

While desire in the $R g$ Veda is not, then, universally cast as a villain of the emotions/drives, it is often cloaked in complex ritual and mythical imagery. Here we can see an illustration of a 'wise one' as desirous - wisdom not seemingly 
precluding the possession of desire. At $\operatorname{Rg}$ Veda 10.5.5, we find an account of the hidden Agni:

Full of desire, ${ }^{18}$ the wise one brought the seven red sisters out of the honey to see. ${ }^{19}$

Much of the time in Vedic texts it seems that desires are things to be fulfilled. One might argue that the Vedas represent, particularly prior to the full development of the doctrine of karma and rebirth, a pre-moral phase of Hindu thought. Although there is not the space to develop this fully, one might argue that the earliest phase of Hindu thought is one in which religion is like science - the means to manipulate the forces of the universe. Rightness for the Vedic ritualist is (sacrificial) competence, ${ }^{20}$ not morality. So, while there may be a concern with ritual intention, the point of the ritual - the reason it is being performed - is not a topic for ethical scrutiny. The ritual is how to get what you want, not a way of transforming the process of wanting itself.

This fulfilment of desire is then, as we would expect, obtained in ways caught up with the ritual and beliefs of Vedic religion, as at $R g$ Veda 9.113.10-11:

Where there are desires and longings ${ }^{21}$ at the sun's zenith, where the dead are fed and satisfied, there make me immortal. O drop of Soma, flow for Indra.

Where there are joys and pleasures, gladness and delight, where the desires of desire are fulfilled, there make me immortal. O drop of Soma, flow for Indra. ${ }^{22}$

We can see this again at $\operatorname{Rg}$ Veda 10.121 .10 , in a rather obscure Vedic hymn much concerned with sacrifice and creation:

O Prajāpati, lord of progeny, no one but you embraces all these creatures. Grant us the desires for which we offer you oblation. Let us be lords of riches. ${ }^{23}$

We can see here the necessary role of desire as an element of the worldstabilising practice of the sacrifice (desire's relation to samkalpa, ritual intention, will be discussed later in this chapter). However some of the later suspicion and concern over unregulated desire may stem from the notion that such forces represent a move away from order, towards chaos. Desire in this sense is the upsetter. Desire is what rocks the boat - human desire can endanger the order of things. This is reason enough to be wary of desire. Order is a powerful image in Hindu thought from its earliest forms. Order is associated with dharma, disorder with adharma. Order is associated with truth. God can be seen as the source of order, and the sacrifice as the means of its preservation, as 
at $\operatorname{Rg}$ Veda 10.190.1-3:

Order and truth were born from heat as it blazed up. From that was born night; from that heat was born the billowy ocean.

From the billowy ocean was born the year, that arranges days and nights, ruling over all that blinks its eyes.

The Arranger has set in their proper place the sun and moon, the sky and the earth, the middle realm of space, and finally the sunlight. ${ }^{24}$

If we see desire as a force of disorder - and uncontrolled, wayward or over-strong desire would seem to be an enemy of stability - then we can see the cosmic as well as social and religious forces that would prompt calls for its heavy regulation. It may be, as the next section discusses, that some forms of desire - appropriately directed to the atman - are to be welcomed, but even so that still leaves much of what we conventionally consider as desire as an unwelcome guest in the human psyche. The first quote I used in this examination of the $\mathrm{Rg}$ Veda also illustrated a way in which we might even see it as unwelcome to the 'One'. If we see the universe as emanating from an episode of desire, we might see the whole sacrificial superstructure of Vedic thought as an attempt to regulate this unleashed desire - to hold it back and stabilise the world in the face of this power that would upset the status quo.

But if desire is the force which kick-starts the creative process, that does not mean that once creation has occurred, this primal desire is sated. Once the world has moved from one-ness to many-ness, once multiplicity exists, the desire - and the need for sacrifices to regulate that desire - becomes an ongoing process. As Killingley notes:

In many Vedic narratives the primordial sacrifice is followed by further desire, and therefore further descent into the world of differentiation, which leads to the need for further sacrifice. ${ }^{25}$

The regulation of desire, post-primordial sacrifice is, then, something to be maintained via sacrifice, in a process that will last as long as the world of individuated being persists. I now move from the idea of religion, or key aspects of religion, acting to control desire, to the notion that desire can be seen as being in direct conflict with religious ideals.

An episode where desire is explicitly cast as hindering religious goals (in a way found much more in later Hindu thought) is in a fascinating hymn of the $\mathrm{Rg} \mathrm{Veda}$, at I.179, concerning the married couple Agastya and Lopāmudrā. Agastya practices asceticism and has taken a vow of chastity, from which Lopāmudrā would tempt him in order to have children. What is noteworthy is the way Lopāmudrā describes the way her desire is manifested:

Desire has come upon me for the bull who roars and is held back, ${ }^{26}$ desire engulfing me from this side, that side, all sides. ${ }^{27}$ 
Like the verse at $\mathrm{Rg}$ Veda 10.129 .4 , desire is described as something that works upon the desirer almost from without. Externalising desire is an interesting strategy. Throughout much Hindu literature we find kāma personified, while in much non-Hindu thought it is an impersonal force (such as for Schopenhauer). As an example of the former we find Kāmadeva, kāma as a god. At Atharva Veda 10.9.2, we find a whole hymn dedicated to a personified form of käma. In this hymn we see the primacy of kāma amongst the gods asserted:

Kāma was born at first; him neither the gods nor the fathers have equalled. To these art thou superior, and ever great; to thee, O Kāma, do I verily offer reverence. ${ }^{28}$

Somewhat later in Hindu thought, kāma is often personified again, but here in a role a little like a god of love:

In post-Vedic literature, people who are hopelessly in love are described as afflicted by the arrow or arrows of Kāma. ${ }^{29}$

N. J. Shende traces the origins of the use of käma as the basis of love right back to the Atharva Veda:

Thus Kāma in the mind of men and women is considered to be the same as the creative power of the universe. Kāma is identified with Agni, to whom offerings are made. This identification is quite appropriate, since, he, the first god born, produces fire or heat in the hearts of the lovers $\left(9 \cdot 2 \cdot 1 \cdot 19^{30}\right)$. The men and women fallen in love with each other are the representatives of Kāma. Love is the basis of creation. Thus Kāma is the creator. ${ }^{31}$

We can see the romantic role of kāma in, for example, the seventeenth century Hindi poet Bihārī’s work, the Satasī:

Kāma, the wily huntsman, has taught her so, dear lad, that with her piercing glances that fawn-eyed girl of elongated eyes wounds gallants of the town, turning the hunter hunted. ${ }^{32}$

Furthermore, seeing desire as a force without us may strengthen images of resistance, and may also be implicated in descriptions of the Self as separate from the realm of desire. But, if desire is external, where does it come from? It surely cannot be a feature of the underlying Brahman, the true nature of reality, ${ }^{33}$ but is it integral to the nature of $m \bar{a} y \bar{a}$, the first hook of delusion? Māy $y \bar{a}$ as illusion ${ }^{34}$ is also seen as the external illusion at times, so we might view externalised desire 
as analogous to, or a feature of, the way the ignorance of true reality is also externalised as illusion.

We can see desire as both internal and external, for ultimately such distinctions are misleading - the gods represent elements of consciousness, just as consciousness may mirror the pantheon of devas:

although kāma is a product of the mind, this does not mean that it results from a conscious act of will. The mythology of kāmadeva represents kāma as a force which attacks the individual from the outside, both when his flower arrows cause love at first sight in ordinary mortals, and when he attacks Śiva. ${ }^{35}$

Käma is a force which feels as though it descends upon us from outside; we are aware of this from the moment we are taught, or learn, that we can not (because we should not) always get everything we want: ${ }^{36}$ - we have desires that are contrary to what we perceive as our principles or welfare.

To return to Agastya and his wife's desire, we find a proposed solution to their dilemma. ${ }^{37}$ Despite succumbing to his wife's advances, Agastya somehow maintains his spiritual path due to his proficiency as a sage. Desire though is seen as something to be wary of - we shall see much more of it as that which would disturb the calm sought by the spiritual aspirant.

\section{Desire as the enemy of the spiritual}

As we move on, we begin to see the notion of desire for the Self as freedom from desire. Desire, as we shall shortly see, must be redirected to the appropriate object the Self. This is seen as equivalent to the transcending or elimination of desire. If we look to the Atharva Veda, at 10.8.44, we find a verse resonant with many of those found in the Upaniṣads:

Free from desire, immortal, wise and self-existent, With [its own] savour satisfied, and nothing lacking, Whoso knows him, the Self, - wise ageless, [ever] young, Of death will have no fear. ${ }^{38}$

While there is some ambiguity in the text, ${ }^{39}$ the ideas around desire are interesting. Here, the same thing that is 'free from desire' is that which is 'satisfied'. Maybe the desire for the Self is, given the transient nature of the world, the only desire that can be satisfied. The idea may be that desire for the Self is one where the 'savour' is satisfied. So, as we move on, there is the idea of desire - in its negative roles - as being either desire for the wrong thing - that is, not for the Self - or desire not satisfied; which from the spiritually enlightened position are identical. 
This is echoed in a passage at Bṛad-āranyaka Upaniṣad 4.3.21:

Clearly, this is the aspect of his where all desires are fulfilled, where the Self is the only desire, and which is free from desire and far from sorrows. ${ }^{40}$

Here desire is only negative in part, and to be liberated from only if it is not for the Self. A person who has achieved the state referred to in this verse is one who has no desire for anything that is part of the world of multiplicity. ${ }^{41}$ As the preceding verse (Brhad-äranyaka Upanișad 4.3.21) makes clear, it is a state of Self-absorption - an absorption of the àtman:

It is like this. As a man embraced by a woman he loves is oblivious to everything within and without, so this person embraced by the self ${ }^{42}$ consisting of knowledge is oblivious to everything within or without. ${ }^{43}$

The notion of freedom from desire is a theme in Vedic discussion, in which there is a clear recognition of the problem that unfulfilled desires poses. In praising the stones used to ritually press the Soma, $R g$ Veda hymn 10.94 describes them in contrast to the flawed nature of humanity:

Porous or not porous, the stones never tire, never rest, never die; they are never sick or old or shaken by passion; nicely fat they are free from thirst and desire. ${ }^{44}$

Here we see the Soma stones as complete - what Sartre would refer to as être-en-soi, 'being-in-itself'. As humans, however, we are not complete. Not only do we suffer the ravages of ageing, sickness and death, but our very nature is incomplete. Desire is the force that confirms us as not être-en-soi, but as être-pour-soi. 'Being-for-itself' rather than 'in-itself' is distinguished as the possession of consciousness, but consciousness as nihilation of being-in-itself. ${ }^{45}$ The theme of the desirability - and indeed the attainability - of freedom from desire is discussed further with relation to the Upanișads, as well as clearly being a central theme in Chapter 3's discussion of nibbāna as desirelessness.

The hymn to Soma mentioned previously (Rg Veda 9.113) praises Soma directly because it can fulfil desires. While I am in no position at this point to speculate on the psychotropic or narcotic effect of Soma, it is noteworthy that what may be the appeal of many narcotic substances is their effect on desire. While we may condemn such substances for making us slaves to insatiable and dangerously insistent desires, surely one of their most potent characteristics is the fulfilment they offer one who seeks them out. That is, one of the most desirable things about drugs is their ability to make us feel sated. Under the influence of a narcotic, we no longer want it - if the effect of the drug is all we desire, is what drives our life, then when we are fulfilled in this regard, we sit, alas all too briefly, beyond the reach of desire's cruel touch. 
If desire is the upsetter, that which drives our angst and causes the subtle, inescapable drive of $d u k k h a$, perhaps narcotics such as opiates and cannabis ${ }^{46}$ can make us comfortable. Clearly the transience of such chemical comfort, and its flipside of inflamed and enraged desire, make it unsatisfactory as a spiritual goal, and most probably self-defeating with regard to desire. Nonetheless we get a clearer picture of the appeal of such substances if we view them as offering significant, albeit brief, respite from the dis-ease of our own lack-of-being manifested as desire.

We have begun now to look at material from beyond the Veda Samhitās, and in looking at the Upanisads we find some shifts in the assessment of desire. In the Upanișads we find much of the Vedic position retained, although the later Upanișads see a move away from the power of desire, towards concerns over its regulation culminating in the approach of the Bhagavad Gĩtā. In some places in the Upanișads though, desire retains its creative power, as at Chāndogya Upanișad 8.2.1-10:

If such a person desires the world of the fathers, by his intention alone fathers rise up. And securing the world of the fathers, he rejoices. ${ }^{47}$

This formula is repeated for various objects of desires: world of mothers, world of singing and dancing, the world of friends, etc., till we reach 8.2.10:

Whatever may be the object of his desire, anything that he may desire, by his intention alone it rises up. And securing it, he rejoices.

This is a startlingly clear expression of desire as creative. But if we look more closely it seems that the mechanism of fulfilment is via 'intention' - samkalpa. The term samkalpa can be viewed in Vedic contexts as ritual intention - a necessary element for the success of the sacrifice. We might view samkalpa as describing the way in which the sacrifice is - to an extent - the harnessing of desire in a ritual context. ${ }^{48}$ The term has a range of meanings, and some of the ones the SED gives are: 'conception or idea or notion formed in the mind or heart, (esp.) will, volition, desire' ${ }^{49}$ Although the term develops other meanings in later thought, it becomes a feature of the process of perception. Killingley notes its Vedic usage:

In Vedic thought, however, the term implies an element of intention; it is a function of the mind which directs a person towards a goal, and gives purpose to action. ${ }^{50}$

So, we can see here an explicit retention of the notion of desire as creative and powerful. Chapple, in seeking to understand the nature of creativity in Hinduism, recognises the importance of the passage cited above. Discussing Chändogya Upanișad 8.2 as a whole, he claims:

the eighth chapter asserts, desire for the true self is higher than pursuing worldly things. The text states that by the mere power of conception (samkalpa) the desired result is obtained. ${ }^{51}$ 
So, desire can give us what we want through the very wanting itself! Chapple and the text point out, though, that this is a lowly goal in spiritual terms. The only true desire, the only one that brings lasting satisfaction is the desire for the Self. However, this does reinforce the notion of desire as creative that began at $\mathrm{Rg} \mathrm{Veda}$ 10.129.4, as Killingley writes:

kāma is not merely a mental state, but a power which can subdue rivals or even create the cosmos. ${ }^{52}$

We can see this power of desire and its role in creation echoing some of the Vedic passages mentioned earlier in an Upanișadic passage which place desire within the mechanics of an account of the creative process. In Brhad-äranyaka Upanisad 1.2, we find a version of creation that has death as creator, death being associated with hunger: ${ }^{53}$

In the beginning there was nothing here at all. Death alone covered this completely, as did hunger; for what is hunger but death? Then death made up his mind: 'Let me equip myself with a body. ${ }^{54}$

If we see death as hunger, we can see death as satisfying itself (as hunger) in the act of creation. In this account, death wishes for a body, and uses desire as the means of a sacrificial-ritual process, which becomes associated with the Vedic horse sacrifice. Through Brhad-äranyaka Upanișad 1.2.4-7 we repeatedly find the phrase "Then death had this desire', 55 followed by complex ritual imagery leading to the satisfaction of death's desire and the unfolding of the creative process. Desire here is the fuel driving the engine of creation.

Why death is described here as hunger is not obvious. One might argue that both are characterised by absence. ${ }^{56}$ What is death but a lack of life, an absence of the vitality of the living; and what is hunger but lack of food (or whatever the hunger is for). Here we find hunger satisfied through creation, and death becomes that with a body in a world of life; the lack leads to a desire for fulfilment, to have the absence filled; in turn this desire leads to the cessation of the lack via both ritual and the desire itself. Like samkalpa in a Vedic ritual, the desires of death drive forward the process, want being the source of its ending. Chapple recognises the role of desire in creative processes in Hinduism. He writes of the creative process in the Upanișads:

However, powers of Prajāpati are universal human abilities manifested through desire and the fulfilment of desire through intentional acts. The creative process is engaged through sacrifice. Desire and tapas allow Prajāpati to create; these allow humans to bring forth desired realms. ${ }^{57}$

Desire makes the world - for gods in the grand creative process, and for humans in sacrificial rituals, and maybe even in the construction of our mundane experience. 
While this is by no means a coherent message, desire is almost always seen as a force, a thing of great power. In this light perhaps we should see many of the warnings about desire as arising out of a belief that it is too dangerous for humans to mess with. This idea is that gods may create with the tool of desire, but should humans seek to wield this power for their own ends, it may overcome them and achieve ends other than those they seek. ${ }^{58}$

Once we move into looking at a wider - and later - range of Upanișadic material, we begin to see desire discussed at much greater length. We also find emerging more clearly the idea of desire as an obstacle to religious life and spiritual progress. In a passage at Chändogya Upanișad 4.10.34.10, we see the potential of desire to be hazardous. The student Upakosala Kāmalāyana is abandoned by Satyakāma Jābāla, his teacher, and he expresses his concerns over his desires:

His teacher's wife told him: 'Come on student, eat. Why have you stopped eating?' He told her: 'The desires that lurk within this man are many and bring various dangers. I am overwhelmed by affliction, and I will not eat. ${ }^{59}$

In the absence of his teacher, the sacrificial fires he has tended teach him the nature of Brahman - freeing him of his affliction. Desire here is clearly flagged as a sign of unrest internally, carrying danger and worry for the desirer.

If we look to Brhad-äranyaka Upanișad 6.1.4 we see how desire is used in a conventional sense, as we noted with regard to many Vedic texts - without condemnation. Here ritual knowledge is of pragmatic use:

When a man knows this [the correspondence is hearing], whatever he desires is fulfilled for him. ${ }^{60}$

Indeed we find a specific ritual at Brhad-āranyaka Upanisad 6.3.1 for removal of obstacles to the fulfilment of desire. After ritual preparations, ghee should be poured into the sacrificial fire with the words:

Those stumbling-blocks within you, O Fire,

The gods who frustrate man's desires;

I offer a share to them!

May they be satisfied!

May they satisfy my every desire!

Svāhā! ${ }^{61}$

In Chändogya Upanișad 1.1.8, we have a similar message, albeit caught up in complex imagery around $O m$, where the chanting of the sacred syllable is the means of desire's fulfilment:

So, when someone knows this ${ }^{62}$ and venerates the High Chant as this syllable, he will surely become a man who satisfies desire. ${ }^{63}$ 
Later, at Chāndogya Upanișad 1.7.9, we find again ritual as the means to satisfaction, although here the way to getting what you want is via singing the Säman chant. In the Māndūkya Upanișad (at 1.9), the technical discussion of Om tells us that knowledge of it leads to the satisfaction of desires:

Anyone who knows this [that $O m$ is the ätman] is sure to obtain all his desires. ${ }^{64}$

The Maitri Upanișad (at 6.4) reinforces this view regarding the efficacy of $O m$ as a satisfier of desires:

Surely this syllable is holy,

Surely this syllable is all-high,

Whoso shall know this syllable,

What he desires ${ }^{65}$ is his! ${ }^{66}$

Not only do we find here the use of $\mathrm{Om}$ as a means to satisfying desire, but also the connection between desire and knowledge. Satisfaction of desires is often associated, in the Upanișads, with knowledge. ${ }^{67}$ Most commonly, as at Taittrīya Upanisad 2.1.1, it is associated with knowledge of Brahman:

A man who knows brahman obtains the highest there is. On this we have the following verse: ${ }^{68}$

Truth and knowledge,

Th'infinite and brahman-

A man who knows them as

hidden in the deepest cavity,

hidden in the highest heaven;

Attains all his desires,

Together with the wise brahman. ${ }^{69}$

Here the attainer of knowledge of Brahman will attain his desires. We see in these verses the lingering ritual-like belief in religion as the means to obtaining the goals of our desires. However the line taken on desire is not always clear, as at Brhad-ăranyaka Upaniṣad 1.4.17:

In the beginning this world was only the self, only one. He had this desire: 'I wish I had a wife so that I could father offspring. I wish I had wealth so I could perform rites.' That is the full extent of desire; one does not get anything more, even if one desires it. ${ }^{70}$

This is interesting, if obscure - it is not wholly clear what is meant here by the full extent of desire; maybe that all sub-desires are only forms of these basic desires. 
Again, at Brhad-äranyaka Upanisad 3.2, there is a section regarding the 'grasper' and the 'overgrasper' that is far from clear, and while desire is mentioned, the meaning is not clear. It precedes the famous discussion of karma (action), but how it leads to this important discussion is not clear. It seems to be exploring the relation between sensation and the senses, although it goes a little beyond this. It is notable that desire is seen here as a feature of mind, listed with mind as one of the eight 'graspers and overgraspers' (3.2.7).

The mind is a grasper, which is itself grasped by desire, the overgrasper; for one entertains desires by means of the mind. ${ }^{71}$

Elsewhere in the Brhad-ăranyaka Upanișad there is a clearer line, placing desire in a more familiar role (3.5.1):

The Brāhmanas, having known that self, having overcome the desire ${ }^{72}$ for sons, the desire for wealth, the desire for worlds, live the life of mendicants. $^{73}$

Here desire is viewed as something to be overcome - as an obstacle. We also find once more knowledge as a basis for the overcoming of desire. Knowledge of the Self is the end of desire - perhaps in both the sense of the destruction of desire and the proper goal thereof. We also see an interesting object of desire mentioned in this passage - the desire for worlds. This may refer to desires regarding life beyond death, such as the world of the fathers. We see the same list of desires at Brhad-äranyaka Upanișad 4.4.22, and see it again as in tension with proper desire - that is desire for the Self:

It is when they desire ${ }^{74}$ him [the Self] as their world that wandering ascetics undertake the ascetic life of wandering.

It was when they knew this that men of old did not desire ${ }^{75}$ offspring, reasoning: 'Ours is this self, and it is our world. What then is the use of offspring for us?' So they gave up the desire for sons, the desire for wealth, and the desire for worlds, and undertook the mendicant life. The desire for sons, after all, is the same as the desire for wealth, and the desire for wealth is the same as the desire for worlds - both are simply desires. ${ }^{76}$

This treats all desire as the same - but surely it must except desire for the Self as somewhat different? It may imply this, but it is not made clear, and the notion of all desire as essentially the same is not developed any further. Brhad-äranyaka Upanisad 4.4.7 further illustrates the theme on the undesirability of desire (as it were):

When all desires that dwell in the heart are cast away, then does the mortal become immortal, then he attains Brahman here. ${ }^{77}$ 
While this passage does recommend the overcoming of desire, it is pre-fixed by one which, at Brhad-äranyaka Upanișad 4.4.5-6, still recognises the power of desire found in the Vedas. For his act follows his desire, and his act leads, through means such as karma to the goal of that desire:

A man resolves in accordance with desire, acts in accordance with his resolve, and turns out to be in accordance with his action. On this point there is the following verse:

A man who's attached goes with his action,

To that very place which

His mind and character cling ${ }^{78}$

Commenting on this passage, Chapple recognises the power of desire. Desire here is creative in the sense of being the maker of the world-as-we-experience-it:

One's desires lead to the desired world; though deceptively simple, this insight into karma shows that one's mind actively structures the world that is experienced. ${ }^{79}$

While the Kant-like second point Chapple makes is surely uncontentious, what is significant is the key role desire is ascribed in this process of world-construction that our mind carries out. As for the devas of the Vedas, so for us all - desire is the maker of worlds.

Now we shall return to the notion of desire as something to be left behind - and Brihad-äranyaka Upanișad 4.4.5-7 would have us leave it behind. It must be left behind as the worlds made by desire are ones such as this one, worlds of misery and frustration. We find an even stronger illustration of the need to overcome desire in the Taittirizya Upanișad. Here the lack of desire is associated closely with happiness. In a discussion of bliss, various heavenly beings (such as the Gandharvas $^{80}$ ) are compared to one free from desire. The one who has no desire is superior in bliss. The passage is formulaic, and each successive level of bliss is transcended by the one free from desire. For example:

A single measure of the bliss that Indra enjoys - and also a man versed in the Vedas and free from desire - is a hundred times greater than the bliss of the gods. ${ }^{81}$

In Śankkarācārya's commentary on this passage we see reinforced the notion of the abandoning of desire as a means of spiritual progress:

desirelessness has been treated distinctively in order to point out that increase of bliss is independent of the superiority or inferiority of objects. Thus since happiness is seen to improve a hundredfold proportionately with the advance of desirelessness, it is treated here with a view to enjoining dispassionateness as a means for the attainment of supreme bliss. ${ }^{82}$ 
This is in line with the fact that we also, in the Upanișads, find the idea that the abandoning or overcoming of desire is salvific or liberating, such as at Maitri Upanișad 6.30:

Desirelessness ${ }^{83}$ is like the best selection from the best treasury. For the man who is made of all desires, who is marked by resolve, intention, and self-conceit, is bound. ${ }^{84}$ One who is then, opposite of that is released. ${ }^{85}$

Again, at Brhad-äranyaka Upanisad 4.4.6, we find the absence of desire as the means to religious salvation:

But the man who does not desire, he who is without desire, who is freed from desire, whose desire is satisfied, whose desire is the self; his breaths do not depart. Being Brahman he goes to Brahman.

Given that desire is creative and powerful, why should we leave it behind, rather than use it as a means to obtain salvation? Because salvation is related, as noted, to establishing - or knowing - unity of the Self and the One, while desire is a force of division rather than unity, as Killingley notes:

Desire, as we have seen, belongs to the world of multiplicity, which is time-bound and unstable. While Vedic cosmogony begins with a primordial unity, which is prompted by kāma to become many, the way to salvation lies in the opposite direction: from multiplicity to unity through the abandonment of kāma. ${ }^{86}$

Note also that in the passage above (Brhad-äranyaka Upanișad 4.4.6) we have the idea of the lack of desire due not to desire's being extinguished, but to its being satisfied. This is a theme which we see developed throughout the Upanișadic material, remaining a live issue beyond the time of the Bhagavad Git sition, indeed to the present day. Whether to redirect or remove desire - this question haunts Indian thought, not always visible, but present. Much of the confusion over Buddhist accounts of desire can be traced to a failure to realise the significance of this question. ${ }^{87}$

I want, now, to return to the notion of knowledge as liberating. This is a thread running through the Upanișads. In fact, the whole of the fifth Brāhmana of the Brhad-äranyaka Upanișad is concerned with renunciation as a means to knowledge of Brahman. This view is also found in later Hindu literature, as in a verse from the Mahābhärata (12.174.37):

The gods consider him to be a knower of Brahman who has no desires, who undertakes no work, who does not bow (to others) or praise (any one), who remains unchanged, whose work is exhausted. ${ }^{88}$ 
Here knowledge is closely linked to the absence of desire. In the last chapter we saw absence, or lack, as the basis of how much desire was understood. Further comparative analysis is to be found in Chapter 5, but it is appropriate to ask here whether Hinduism takes the same view. It would seem that the answer to this may depend on whether we are discussing desire for worldly objects, or the desire for the Self. One might suggest that desire for things other than the Self relates to lack, while desire for the Self is desire for something that you cannot lack. In knowing the Self, all other desires are both quietened and revealed as futile.

If we wish to see a view of desire as without lack, perhaps one can get the best sense of it from a Chāndogya Upanișad verse at 3.14.2-3, where the Self, the $\bar{a} t m a n$, is seen as containing all desire ${ }^{89}$ - and the atman is surely without lack, for it is complete:

This self (ätman) of mine that lies deep within my heart - it is made of mind; the vital functions are its physical form; luminous is its appearance; the real is its intention; space is its essence; it contains all actions, all desires, all smells, and all tastes; it has captured this whole world. ${ }^{90}$

Perhaps what is problematic for us as humans is our lack of knowledge of our own lack of lack! If we do have an unshakeable ätman which is complete, we need nothing. Our ignorance of this though may be seen as the root of our seeking the fulfilment of desire elsewhere - inevitably leading to frustration and unhappiness. In one sense, satisfaction can be sought anywhere - due to the pervasive nature of Brahman$\bar{A}$ tman - but this is not, as a rule, what we are doing when we desire things in the outside world - for what we desire is usually part of $m \bar{a} y \bar{a}$, or transient and therefore unfulfilling. Still looking outwards, the most obvious form in which we may find this ultimate is in God - particularly in a transcendent sense; but many traditions within Hinduism do venerate components of the natural world as containing the ultimate Brahman - tending towards divinity as immanent. However, for the composers of the Upanișads, the most accessible form of it is that within us - the Self.

So, the Self is the key to fulfilment. Certainly, it is one route, the Upanișads propose, to the sating of our desire. This is made clear throughout the Chandogya Upanisad. At 8.7.3 the quest for the Self is described, as are the features of that sought:

The self that is free from evils, free from old age and death, free from sorrow, free from hunger and thirst; the self whose desires and intentions ${ }^{91}$ are real - that is the self that you should try to discover, that is the self that you should seek to perceive. When someone discovers that self and perceives it, he obtains all the worlds, and all his desires are fulfilled. ${ }^{92}$

What distinguishes this verse from the one quoted next is the reference to the desires of the Self itself. That the desires of the Self are 'real' is intriguing. Are we to read this as asserting that the Self has appropriate desire? Maybe, but as we 
have seen appropriate desire is desire for the Self - or $\operatorname{Brahman}^{93}$ - so is this the Self desiring itself? While this is opaque here, we can see how whatever way it is that the Self desires, it is in a way that lies beyond our mundane desiring. One might speculate ${ }^{94}$ that this is a means of entrapping desire, of holding it captive within the ultimate. The desire for the Self, within the Self, is of necessity permanently fulfilled. In this circle of Self-satisfaction, there is no room for desire as the upsetter; it has been placed where it can do no harm. However, as mentioned shortly, the Self is also described in terms of being free from desire, which me might choose to read as free from worldly or dangerous inappropriate desire indeed to comply with our previous terminology we might call this being free from desire for anything beyond the One, for multiplicity.

It is in this context that we should read the passages at Chändogya Upanisad 8.12.6 where we see again the Self as the means of desire's fulfilment - and for gods as well as humans:

It is this self that the gods venerate, as a result of which they have obtained all the worlds and have had all their desires fulfilled. Likewise, when someone discovers this self and comes to perceive it, he will obtain all the worlds and have all his desires fulfilled. ${ }^{95}$

The Self, the focus for much Upanișadic material, is not only the means to fulfil desire and the proper object of desire, it is also - at least in some passages - free from desire itself, as Maitri Upanișad 2.7 illustrates:

He is indeed the pure, the stable, the unmoved, the unaffected, unflurried, free from desire, ${ }^{96}$ standing still like a spectator, self-subsistent. ${ }^{97}$

The contrast with Chāndogya Upanisad 8.7.3 (above) is noteworthy, for here the Self is described as being free from desire. When listing all the qualities of the Self (in a slightly personified form), we get a reference to desire in the context of equanimity - a notion which comes to prominence later in Hinduism, as well as having a key role to play in Buddhist thought.

And if the Self is the same as the ultimate Brahman, it is no surprise to find passages where it is in Brahman manifested as God that we find the fulfilment of desires. The Śvetāśvatara Upanișad is described by Olivelle as a:

somewhat late text composed under the influence of both the SāmkhyaYoga tradition and the emerging theistic tendencies. ${ }^{98}$

Given this, it makes sense that here it is God who provides the focus of knowledge and fulfilment:

When one has known God, all the fetters fall off; by the eradication of the blemishes, birth and death come to an end; by meditating on him, 
one obtains, at the dissolution of the body, a third - sovereignty over all; and in the absolute one's desires are fulfilled..$^{99}$

Despite the shift to a more theistic tone, the theme is still of the fulfilment of desire. This fulfilment is, though, throughout the Upanisads as we have seen, associated with freedom from desire. It is a type of desire which finds its fulfilment due to its particular nature as having the right object. In Chapter 3, looking at Buddhism we will ask if there is more to appropriate desires than their possessing the appropriate object, but this distinction is largely absent or ambiguous in the Vedic and Upanișadic passages I have looked at here.

A passage which shows this ambiguity is in the Mundaka Upanișad at 3.2.2, where the transcending of the world of desires and rebirth is via the fulfilment of desire:
One who hankers ${ }^{100}$ after desires in his thoughts, is born here and there through his actions.
But when one's desires are fulfilled, and one's self is made perfect, all his desires disappear in this very world. ${ }^{101}$

Here we see that appropriate desire causes inappropriate desire to evaporate, but there is no conscious effort to develop a systematic typology of desire. One point at which we do find a clarification of what is meant by being 'desireless' is in Śankarācārya's commentary to the Kața Upanișad:

A desireless man, i.e. one whose intellect has been withdrawn from all outer objects, seen or unseen. ${ }^{102}$

Here we might claim a distinction between negative desires (external ones) at least in terms of their object, and desire for the Self (the appropriate object of desire, especially for a Vedāntin such as Śankarācārya) (internal desire). This is a rather crude approach though, and is problematised by the claim that the subject/object distinction is a feature of $m \bar{a} y \bar{a}$ and that the goal of the yogin is the realisation of the ground of the inner and ground of the outer as identical, of atman as Brahman! ${ }^{103}$ It is a systematic typology of desire, clearly lacking in Upanișadic texts, that I will suggest is, in the next chapter, a Buddhist innovation.

What the Veda does see, and what is still present in much of the Upanisads before seeming to be partly subsumed by a suspicion of desire, is the power of desire. Not only the metaphysical creativity of desire in the hands of the devas, but the power of desire to announce possibilities in the human realm, in the käma-loka. We saw desire as the maker of the world, from how intention causes its own satisfaction, to how desire drives the spiritual and worldly aspects of life for us all. 
What we have seen in the early Vedic literature is a less cautious and more imperative sense of desire. Desire is indeed a power, a danger. So much so that in human hands it requires significant regulation. One might argue that for many of the Vedic texts, what is required is not the total removal of desire, but correct desire. This might be characterised as the realisation that we are not in lack, but that the true desire is the re-integrating desire for the Self. As we moved through Upanișadic literature there began to be more common the view that desire is something to be removed, transcended and possibly even destroyed. Elements of the Vedic view remain, but the overall picture is far from clear and poses as many questions as it answers.

If one compares the Upanișads with the literature of early Buddhism, it would seem apparent that the Buddhist approach is significantly more psychological in its treatment of phenomena such as desire. The next two chapters will demonstrate this amply, as the processes of mind and the arising of mind-states are key topics of extended debate in the Sutta-pitaka as well as in the Abhidhamma-pitaka. However, such analysis is not wholly absent from Hindu thought.

In regard to the arising of the mind-state of desire, the Advaita-vedānta thinker Śankarācārya ascribes to desire the same root condition as many Buddhist texts. In his commentary to the İśa Upanișad he tells us that the root of desire is avidyā:

avidy $\bar{a}$, which is the seed of desire and work, and is blinding by nature ${ }^{104}$

As we shall see in the Chapters 3 and 4, the notion of avidya plays an important role in the Buddhist understanding of the conditions of desire, and indeed existence itself. The SED describes avidy $\bar{a}$ as 'ignorance, spiritual ignorance' 105 - but notes that in Vedānta philosophy it can also have the sense of 'illusion (personified as Māyāa) ${ }^{106}$ Although Śankarācārya is a Vedāntin, he could here be using avidya in both senses, for the world experienced as $m \bar{a} y \bar{a}$ is the same - at least for us as experiencers of the world - as spiritual ignorance. Being subject (or indeed, self-subjected) to $m \bar{a} y \bar{a}$ is to be ignorant of how things really are.

This view of desire as being rooted in ignorance is well fitted to the Vedāntin stress on knowledge as a means to liberation. Indeed, it fits equally well with the Upanișads as discussed here. While the Upanișads do not make this explicit, Śankarācārya's claim is compatible with them. We shall see in Chapters 3 and 4 just how significant it is for a religious outlook if we ascribe the cause of much (maybe most, maybe even all) of our sorrows (and desire) to ignorance, or lack of spiritual insight.

While insight becomes a core value in early Buddhism, ${ }^{107}$ the stress on knowledge as salvific in Hinduism might be argued to be - at least for a while eclipsed by the success of the bhakti traditions, emerging in late Upanisads and popularised by the Bhagavad Gìtā.

In this examination of the Upanisads, there have emerged tensions between the abandonment of desire and the Vedic model of it as creative. The way that $\mathrm{Rg}$ Veda 
10.129.4 describes desire is clearly creative. Nicholas Lash cites R. Panikkar (who here translates kāma as 'love') in this passage:

Primordial love is neither a transitive nor an intransitive act... it is the constitutive act by which existence came into being. Without love there is no being. ${ }^{108}$

Lash also quotes A. de Nicholas' book on the Gĩtā wherein he claims:

Desire is the fountain of creation in Indian philosophy from the Rg Veda through the Upanișads to the Gīta. ${ }^{109}$

While the Upanișads do indeed not deny the creative force of desire, it does become a less common motif as we move away from the Vedas, through the Upanișads and towards the Gītā.

We might then view the Upanisads as a period of complex transition and slow evolution of the notion of desire. Old meanings are not denied or ignored, but a new focus on either denying desire or re-orientating it comes to the fore. Whether these are the same thing, compatible or in tension is not wholly clear. It is with this in mind that we must turn to a text renowned for its treatment of desire: the Bhagavad Gîtā.

\section{Desire in the Bhagavad Gïtā}

The Git $t \bar{a}^{110}$ has many themes, but desire lies at the heart of them. Dermot Killingley makes clear the centrality of desire to the Gìt $\bar{a}$ :

The Bhagavadgītā abounds in words for desire, pleasure, enjoyment, wish, will, attachment, longing and love. Some of these words, such as lobha ('greed'), have moral connotations, but most of them are morally neutral. Passages referring to the opposite of desire - hatred or disgust are also relevant; so are those on equanimity or indifference (samatva, sāmya). This is one of the recurrent topics of the poem. ${ }^{111}$

Clearly there is much in the Gìtā regarding desire; indeed Killingley goes as far as claiming that it dominates 'the narrative frame of the poem'. ${ }^{112}$ Further than this, the Gîta seeks to place desire in an ethical context.

Many might suggest that 'desireless action' is the key message of the Gìtā, but there is clearly more to it than this. Desire has been developed as a concept throughout the Vedic-Upanișadic literature. However, the question that Lipner poses above is not answered in that literature. At times there is a suggestion that the problem with desire is in its misapplication. That is, that we must point our wanting inwards to the atman - or in more theistic strands to God - and not at worldly objects. As we have seen, some of the passages quoted do seem to hint at a qualitative distinction between desires for worldly things, and desires of a religious nature, but it remains implicit. This leaves it as an open question for the 
Gitta. I am grateful for Nicholas Lash's 'The Purification of Desire' in which he explores this theme which has been lurking throughout all of this chapter so far, as well as haunting much Christian thought on desire:

When as a Christian Theologian, I read the Gìtā, I recognise, in its treatment of desire, an ambivalence that I have met elsewhere: an ambivalence as to whether the peace at which our hearts are set fulfils desire or springs from its suppression. ${ }^{113}$

Before looking at the extent to which the Git tà can offer an answer to Lash's question, I wish to return to Killingley's claim that the narrative of the Git $t \bar{a}$ is framed by desire. From the outset it is clear that the narrative setting is one of conflicting desires. Arjuna is in a dilemma, drawn between two incompatible desires. He wishes for victory - the battle is at hand which will provide both the quashing of the unjust and the fulfilment of his dharma as a ksatriya. Initially he seems keen enough on the task at hand. At 1.20-22:

Then (Arjuna) whose banner is an ape,

Gazed upon the serried ranks

Of Dhritarāshtra's sons. The clash of arms

Began. He lifted up his bow.

To Krishna then

These words he spake:

'Halt thou my chariot [here]

Between the armies twain

That I may see these men drawn up,

Spoiling for the fight,

[That I may see] with whom I must do battle

In this enterprise of war. ${ }^{114}$

There appears little reticence as yet here. But it is not long before his famous doubts emerge. Arjuna's wish for victory comes up against the obstacle of his conscience. From 1.28 to 1.46 Arjuna is aghast at what he is about to do, till at 1.47:

So saying Arjuna sat down

Upon the chariot-seat [though] battle [had begun],

Let slip his bow and arrows,

His mind distraught with grief. ${ }^{115}$

But he stays. Arjuna does not flee the scene. He is clearly unsure, as at 2.7 where he says to Kṛ̣ṇa:

With my mind perplexed concerning right and wrong (dharma) [I turn]

to thee and ask:

Which is the better course? ${ }^{116}$ 
So, desire is at the fore as a source of conflict from the outset. Of course, this is not the most famous element of desire. Most accounts of the Gìtā see as its key theme that of desireless action. This is the famed reconciliation of renunciation and dharma. The renunciant tradition can be seen as in conflict with the alternative ideal of the duties of family life and the carrying out of dharma, especially the householder àśrama. The Gìtā shows a middle-way (another one!), a means to conflate these two ideals. Killingley makes the remarkable point that the phrase niṣkäma-karma (desireless action) is one which:

does not occur in the Gìtâ, but which sums up an important part of its teaching. 117

This middle-way can be seen by both a rejection of desire and a legitimisation of it, in the Gìtâ. On one hand much of the text would steer us away from desire, indeed Killingley claims that:

Perhaps the most common occurrence of desire in the Bhagavadgīta is in the form of something to avoid. ${ }^{118}$

This forms a key part of the ideas in the text - while we cannot avoid action, we can avoid desire. As we have seen in other Hindu texts, this rejection of desire seems counterbalanced by ideas of correct or appropriate desire. ${ }^{119}$ As Killingley comments:

the Bhagavadgītà also presents a positive aspect to desire which contrasts with this ideal of desirelessness. ${ }^{120}$

Beyond the ideas of 'right desire' there are other ways in which we might see desire in the dialogue of the Gìtā. An alternative take on desire in the Gitta is discussed by John Brockington, who describes a somewhat more sceptical interpretation one might place on Kṛnna's motives. Kṛ̣ṇa has pragmatic desires - he wishes Arjuna to act (presumably in the battle at hand, but also to encourage action in general) and his dialogue conceals this pragmatism:

When Krishna tells Arjuna to act without desire for the fruits of his actions, he has base desires of his own in championing the self-interest of the gods. ${ }^{121}$

Clearly, this is a rather heterodox reading, but it should alert us to the way gods are represented in much Hindu thought. While supposedly aloof and beyond desire, they often act to achieve their own specific ends. An orthodox Brahmin might be tempted to ask - like Plato's call for the ejection of the artist from the ideal state in The Republic - for a censoring of the devas' personal and petty squabbling from the epics, but I have never encountered such a call. 
We have seen that the Gìtā offers what seems to be a mixed message about desire. Let us see how another writer's approach addresses the question of desirelessness. The interpretation of the Gitta as offering a model of desireless action is offered, and described clearly, by Madeleine Biardeau:

Although it draws the attention of its devotees back towards this world, bhakti does not jettison the Upanișadic renouncer's analysis of desire as the motivating force behind human acts; however, its conclusions run in the opposite direction. If, in the act, it is desire which is bad and alienating, then it is desire which must be suppressed rather than the act. ${ }^{122}$

Furthermore, her view - expressed at the outset of this chapter that all action derives from desire - may cause her a problem given the way she views desireless action:

The problem is clearly that of knowing whether there is any further reason to act once there is no more desire. The anthropology from which we started provides only a negative answer, since all human activity has been placed under the sign of kāma. ${ }^{123}$

Is 'desireless action' not a contradictory notion in the context of this assertion? She does realise this, and offers an analysis of desire in the Gìt $\bar{t}$ to try and resolve it. The approach she takes is one we saw foreshadowed in Upanișadic texts. It is also a response which answers Lash's question of whether to fulfil or suppress. Desire is not to be absolutely annihilated, but rather it must be redirected. As we would expect in the considerably more theistic (than the Upanisads) text of the $G \bar{i} t \bar{a}$, the redirection is towards God - towards the object of bhakti - Krșna. ${ }^{124}$

In many ways, then, we can see the Gìta as concerned with the purification of desire. While the notion of desireless action (if not the phrase) is present, we can see this as simultaneously encapsulating the idea that desires should be focused perpetually on God, and on acting in accordance with dharma. This notion seems captured well by some rather Nietzsche-like lines from T. S. Eliot, where 'The Rock' proclaims:

I say to you: Make perfect your will.

I say: take no thought of the harvest,

But only of proper sowing. ${ }^{125}$

The aforementioned theistic desire should, for the bhakta, supersede and transcend all other desire. As Biardeau suggests:

God, in making himself accessible to his worshipper and granting him his grace, becomes the object of the supreme desire, the one which suppresses all other desires. So it is impossible to explain the teaching of the Gìta on activity without desire without this precondition of a transfer of man's whole capacity for desire onto God. ${ }^{126}$ 
However, this does not wholly resolve the ambiguities of the Gìtā towards desire. While some verses might seem to support this view, such as 7.11:

Power in the powerful I, -

[Such power] as knows nor passion nor desire:

Desire am I in contingent beings,

[But such desire as is] not at war with right (dharma). ${ }^{127}$

Even here the second line is ambiguous - and are those in whom Krṣna is 'power' not contingent beings? It would seem that we have a view of Kṛ̣na as a primeval force within us - almost, maybe, an animating principle.

Either way, the second half of the verse does seem to support the idea of an appropriate, modified, maybe even purified desire. Elsewhere however we still find what looks like an unambivalent condemnation of desire, with none of the nuances of redirection found elsewhere. Verses 3.37 to 3.43 read like a battle-call against desire. At 3.37 Krishna says of desire: 'know this to be thine enemy on earth ${ }^{128}$ and at 3.39:

This is the wise man's eternal foe;

By this is wisdom overcast:

Whatever form it will it takes, -

A fire insatiate! ${ }^{129}$

Strong words. We might be tempted to claim that it is only inappropriate desire that here is being condemned - that of course none of this would apply to the desire for Kṛnna, but if this is meant it is not made clear. Furthermore, at 3.43 the devotee is encouraged to obtain self-knowledge (knowledge of the atman liberating knowledge) and knowledge of God as a means of vanquishing desire. Still discussing desire, Kṛṣna tells Arjuna (and by extension us all):

Know him who is yet higher than the soul;

And of thyself make firm [this] self.

Vanquish the enemy, Arjuna!

[Swift is he] to change his form,

And hard is he to conquer! ${ }^{130}$

What the devotee here is not asked to do is to redirect desire. Vanquishing desire seems some way from its purification. ${ }^{131}$ One may argue that the Gìta achieves its aim of reconciling the renouncer and the householder, but this is a tension also born out of a concern with desire. As Biardeau notes, when comparing the caste Hindu (living out their dharma) with the sannyāsin (seeking mokṣa):

For the man encumbered with desires, the renouncer is a 'free' man, who has cast off his bonds but who pays sufficiently dearly for that freedom 
to consider it superior ${ }^{132}$ and inimitable; for the ascetic, the man living in his caste thinks only of satisfying his desires and prepares only pain for himself. ${ }^{133}$

One may argue that the offered solution of 'desireless action' is successful only if the nature and status of desire is fully resolved in the Gitta , which it arguably is not.

A commentator on the Gitta who believes that desirelessness is impossible is Aurobindo Ghose. Aurobindo has his own motives in his interpretation of the Gìtā, much of his own thought revolving round a doctrine which a theologian might describe as 'salvation through works'. His rejection of the Advaita view was part of his belief that one should not withdraw, but seek spiritual goals in the world not apart from it. Yvonne Williams, writing on Aurobindo's view of the Gītā, summarises his position:

His conclusion is that...there is obviously no such thing as action without desire:

For what we call ordinarily disinterested action is not really desireless; it is simply a replacement of certain smaller personal interests by other larger desires. ${ }^{134}$

He therefore proposes that the greatest of desires is to do work 'for the sake of divine'. ${ }^{135}$

Here we find a view of 'supposed desirelessness' as the reorientation of desire. While we might not wish to concur wholly with Aurobindo's view, this does represent a strategy for escaping the tensions surrounding desire. However, to do so is - especially in the way Aurobindo expresses it - to retain or return to a stratified and hierarchical notion of desire, the debate returning to one concerning which desires are better than others. This seems to ignore much Hindu thought, which recognises the complex and psycho-spiritually problematic nature of desire.

Killingley takes a similar approach to Aurobindo, but feels that we are not arguing over which is the best object of desire, but rather replacing one motivation with another. We still act, but in the absence of desire act from other causes:

This resolution of the problem of desire is made possible by the devotional theology of the Bhagavadgītā, in which the devotee has a personal relationship with God which provides him with a motivation for action which does not depend on his own desires. The same theology solves the problem of God's motivation: he acts for the maintenance of the world, to restore dharma, or to return the love of his devotees, but not out of desire, ${ }^{136}$ since he has no needs of his own. ${ }^{137}$

This attempted resolution is clearer, but resolves desire only if we accept religious devotion as possible in the absence of desire. Religious devotion seems full of longing, even passion, for the divine, but if we categorise these as not being 
desire, we are again working with an implied typology of wanting that is not fully developed or made explicit. It would seem that the bhakta does desire God, indeed should desire God - and as fervently as possible. While, then, the Gìtā puts a strong case for bhakti as the most practical and effective means of religious salvation, it leaves many of the tensions regarding desire that it inherits from Upaniṣadic literature unresolved.

\section{Sex, love and desire: the Kāma Sütra}

If desire for the Self (in the sense of the atman) is a means of moving away from mundane and harmful desires, it is not the only one. Whereas in many cases sensual desires are thought of as the very antithesis of the spiritual, and amongst the most important and difficult class of desires to be abandoned, ${ }^{138}$ in Hindu thought we often find notable exceptions. Hinduism (albeit often through lascivious appreciation of the Käma Sütra) is renowned for its interest in both the romantic and the erotic. Be it erotic temple carvings, or the mischievous Krṣna of the Purānas' relations with the gopis, Hinduism at times seems to overflow with a superfluity of sensuality. However, before we become too immersed in rescuing sexual desire as legitimate, we must be aware that sexual desire is often something one is warned against. At Maitri Upanișad 6.10, we find sensual pleasures as something to be resisted:

Now, like the man in an empty room who does not touch the sexy women when they come in, someone who does not touch sense-objects when they come in is a renouncer, a yogin, a sacrificer to the self. ${ }^{139}$

If we wish to, for now at least, put to one side these worries, and the concerns of conservative Brahmin orthodoxy over such material, how are we to reconcile this with what has been said regarding the undesirability of desire - particularly sensual longing? One approach is to suggest that in love for another, one suppresses one's Self (in the sense of 'selfish' rather then ätman). Love can be selfless, releasing in us a potential for altruism that we may not have even known existed.

If we consider the efforts of both the sannyāsin and the bhakta, how can romantic love relate to either? Clearly, as we shall see later in this chapter, there is the compulsion to seek kāma in the householder āśrama, but this is love as compatible with a life in accordance with dharma, not necessarily a means of spiritual progress. So, can love ever be more than just compatible with the spiritual life? Biardeau makes a strong case for it. To do so, she locates a commonality in the quest of the sannyāsin and the bhakta, for both:

seek salvation in an exit from the self, in an extension of the attman beyond the bounds of the empirical 'ego'. ${ }^{140}$

This may provide a framework for understanding how romantic or amorous desire might be legitimised. Of course, we need to exercise caution here for much of 
what may be described as 'love' may prove to be of a selfish nature - the desire to possess another, to dominate them, or possibly some kind of infatuation. Love here though is what takes us beyond ourselves, makes us forget ourselves. Biardeau allows for the possibility of such an emotion:

desire, in the particular form of amorous desire, was not necessarily of the ego. Whereas, in 'moralizing'141 literature, human love is often contrasted with renunciation as its main enemy, erotic experience, essentially shared physical pleasure, is analyzed as an experience of self-dispossession. And this dispossession is immediately associated with that achieved through yogic concentration; it is the analogue of the religious experience pursued by the renouncer. ${ }^{142}$

Here we see a noble vision of love. This is not the sickly-sweet affected-affection of the greeting-card poet, nor is it the brutal drive for self-gratification of the sexual egotist. In relation to the questions set out in the introduction to this chapter, we can see that we now have suggested - in this type of feeling - the possibility of a true modification of desire. It may seem odd to describe the erotic gymnastics of parts of the Käma Sütra as part of a purification of desire. Nonetheless, if understood and practised in a holistic context, as part of this selfforgetting desire, there is no reason why love (inclusive of romantic and erotic desire, as well as the fulfilment of these desires) cannot prove to be an effective (and satisfying, in more than one sense) means of making progress on the path to religious goals.

We do though need to make a number of distinctions when making claims about the methodology and theoretical frameworks of the harnessing of romantic and sexual desire within Hinduism. This section began by seeking to address a common aspect in the goal of the sannyāsin and the bhakta. While both may be seeking to transcend or suppress the 'ego-self', key differences still exist between them. ${ }^{143}$ The overwhelming desire and love for God sought in bhakti seems qualitatively different from the desire for the àtman discussed earlier in this chapter.

Such practitioners follow different mārgas. The path of the seeker of the Self is as a follower of jnana-yoga, one yoked to the quest for knowledge of the supreme Brahman. The bhakta seeks by a different means. The devotee of, for example, Krșna seeks to stir emotion for the divine. The burning love of the bhakta is full of passion. ${ }^{144}$ An example of such practices is found in the Nārada Bhakti-Sütra. ${ }^{145}$ Here the text puts the bhakta through an emotional process likely to lead to states far from the inner-silence of the yogin:

Kṛ̣na should be worshipped in varying degrees of emotional attachment: from perception of the Lord's majestic glory to experiencing the various emotions associated with the role of Kṛṣna's slave, his companion, his parent and finally his wife. ${ }^{146}$ 
These roles suggest a life of desire, of passion - but with the passion being for the Lord. A jñana-yoga follower, on the other hand, seeks not a clamour of passion, but an inner-silence - something more akin to Buddhist methods. Clarity of vision necessitates stillness and calm. As an illustration of this, we might look to dhäraṇa, the sixth stage of Patañjāli's Eight-Limbed Yoga system. This singlepointed concentration requires the elimination of all churnings of the heart. It can only be achieved once the body is quietened and the senses withdrawn. By this, I mean that the body must be stilled such that it largely ceases to impinge on the mind - and any minor intrusions it may make into our consciousness are foiled by this withdrawal of the senses. This latter process equates to what the Buddhist Abhidhamma might call a 'shutting of the sense doors'.

Further, the mind must achieve sufficient states of calmness. B. K. S. Iyengar, the most influential of modern Yoga teachers - who explicitly models his approach on Patañjāli's - describes what is needed to achieve dhäraṇa:

The mind has to be stilled in order to achieve this state of complete absorption. ${ }^{147}$

The last word here is intriguing, for it represents what both methods share - the pursuit of absorption. This is the state whereby the veil of $m \bar{a} y \bar{a}$ falls away, and we know nothing but the object, possibly now being even beyond the subject/object distinction. In this type of yoga, ${ }^{148}$ this may just be the object of concentration, but for both the passionate bhakta and the renunciant seeking the Self, it is total absorption of consciousness in the object of desire. We can see now how a sexual rapture might be analogous to such states, a sense that the rest of the world has ceased to exist. Likewise, romantic states are renowned for making monomaniacs of us all.

If we are thinking of the sexual act itself, the clearest connection to the ideas expressed so far is the goal of 'union'. The yogin seeks the state of mystical union, ${ }^{149}$ the sannyāsin - particularly if of an Advaita-vedānta persuasion - seeks the re-merging of the atman with Brahman, ${ }^{150}$ and the bhakta may wish one-ness with God (although they do not seek to become God). ${ }^{151}$

So, we find similarities in the quest of the devotee, the sannyāsin ${ }^{152}$ and the lover. Hindu thought has developed this spiritual utilisation of sexuality and sensuality to a significant degree. As Biardeau argues, when comparing 'the act of love' and 'yogic concentration', ${ }^{153}$ there is more to it than an evocative analogy:

The linkage between the two orders of experience goes much further than the search for an expression of mystic union in terms of human love. ${ }^{154}$

Tantric thought makes much of the union of Purusa and Prakrti and the manner in which the lover's path might not just imitate the mystic union, but actually become part of it. The notion of sexual union as a rapture that transports us out 
of ourselves, beyond the ego, is not identical with the Tantric approach though. We should not presume the Käma Sütra and tantra to take the same approach just because they share the feature of not always disapproving of sexual desire.

Given what I have said regarding the spiritual possibilities of sex and love, I now turn to that well-known Sūtra - titled after desire - the Kāma Sūtra. ${ }^{155}$ While in the context of this work kâma is predominantly seen as sexual desire, there is also a sense in which what is said in the Käma Sütra has a wider application. The primary way that we may view this relates to the three goals of life in traditional Hindu views:

Kāma, in the general sense of 'pleasure', appears third in the well-known list of purusāarthas (aims of man): dharma (righteousness), artha (worldly power, especially wealth), kāma, which in this context is usually translated 'pleasure'. 156

Vātsyāyana is not blind to the dangers of kāma, and its relation to the other goals of life. We find, in the Käma Sütra, an understanding of the integrated nature of the three goals:

the pleasures of Kama are as essential for the proper maintenance of the human body as is food. Moreover, they take their very roots in Dharma and Artha. Granted, one must, however, acknowledge and be aware of the dangers. Do people refrain from cooking food simply because there are beggars? Do they not sow seeds of barely in spite of the deer eating their sprouts?

In this way, a man who pursues Dharma, Artha and Kama, experiences untrammelled happiness both in this world and in the world to come. ${ }^{157}$

Here we can see how even in a text devoted to käma, it is seen as needing to be balanced with duty - with other factors. We see this expressed even more explicitly at $2.14-7$, albeit with some notable exceptions:

Dharma is better than Artha and Artha is better than Kama. But this order of procedure is not applicable in all cases. With a king, Artha is of prime importance, since the very livelihood of his subjects depends on it. Similarly Kama comes first with courtesans. ${ }^{158}$

While discussing the Käma Sütra, however, we do need to be aware of the sense in which Vātsyāyana uses the term kāma. He links it explicitly to sensory desire in a way distinct from the more general use of the term found so far in this chapter:

Kama is the enjoyment of the objects with the help of the five senses of hearing, of speech, of sight, of taste and of smell, according to the dictates of his mind in consonance with his soul. Actually, Kama is that special pleasure experienced when the sense of touch operates, and 
when it is in contact with the object that generates pleasure. Kama is to be learnt from the Kama Sutra and also from the worldly-wise citizen. ${ }^{159}$

This is a limited view of kàma, and the Kāma Sūtra may also seem equally limited in its concerns. That is not to say, however, that it had nothing to tell us about the nature of desire. Perhaps nowhere else in the whole vast mass of Hindu literature is the ambivalence of Hindu approaches to desire more striking than in the Käma Sütra. This text, known primarily for its role as a "manual of the arts of love', is both about the expression of desire - the giving in to desire - and, at the same time, about the regulation of desire.

In S. C. Upadhyaya's introduction to his translation of the Kàma Sütra of Vātsyāyana, we find this expressed explicitly:

This science is mainly concerned with the fulfilment of the desires of the flesh. It aims at teaching a person the best method to control and properly guide the desires, particularly the sexual urge, so that the person may be an useful member of the family, society and his country and contribute his mite to their welfare by his way of life. ${ }^{160}$

Here, while desire is allowed, we see the need for control. In the text, most renowned for its affirmation of the acceptability of desire, we begin with a concern over 'unregulated desire'. If one is not proficient in the expression of one's desire one is in danger! That desire is a force of considerable power is as clear here as it is in the Vedas and the Upanișads. Indeed, Upadhyaya makes this connection when he refers to $\operatorname{Rg}$ Veda 10.129. $1-7^{161}$ - the sacrifice of the primal purusa. He draws a conclusion not dissimilar to my own when he claims:

The first product of the Mind was Kama, sexual desire, love, the bond between the non-existent and existent. As this desire leads to the procreation and birth of beings, the Sages considered it as the primal source of all existence. ${ }^{162}$

This reading attributes to the Vedic passage a sexual sense that was not present in the interpretation I offered on this, and there seems little reason to cast this sexual aspect onto the quote. ${ }^{163}$ However, in one way there is no reason not to - as sexual desire might be seen as the most obviously creative, the basis of procreative acts. Once in the main body of the Käma Sütra, though, we find that its concerns are predominantly practical. In many ways, it is about the manifestations of kāma rather than its nature. It is on this basis that I say no more upon it here.

Before coming to general conclusions about the Hindu understandings of the nature of desire, I wish to turn to another tradition that draws on a Brahmanical backdrop, and also forms part of the intellectual context that informs early Buddhism - Jainism. 


\section{Jainism and desire: the calm fight against karma}

To establish the concurrence of Buddhism and Jainism, we do not have to rely on just the appearance of Nātaputta in Canonical Pali texts, for as Surendranath Dasgupta points out:

The canonical books of the Jains mention as contemporaries of Mahāvīra the same kings as reigned during the Buddha's career. ${ }^{164}$

This is not the place to enter into a comparative study of Gotama and Nātaputta, but it is perhaps worth noting that Jains see their religion as pre-dating Nātaputta. ${ }^{165}$

Before we move on to consider its views on desire, a little needs saying on the primary concerns of the Jain religion. If we wish to get a taste of the Jain religion, we must recall as foremost its concern with asceticism and non-harm. The rigours of a Jain monk exceed, in most cases, those of Buddhist ones. Often hair may be plucked from the head, rather than shaved, ${ }^{166}$ and monks' nightly sleep may be limited to three hours.

The determination to avoid the killing of a living being (and therefore the avoidance of the formation of karma-constructions) is an inescapable motif throughout Jainism. This extends from the monastic duties of inspecting clothes and holding a cloth over the mouth during speech, to the expectations placed upon the laity:

The principle of extreme carefulness not to destroy any living being has been in monastic life carried out to its very last consequences, and has shaped the conduct of the laity in a great measure. No layman will intentionally kill any living being, not even an insect, however troublesome. He will remove it carefully without hurting it. ${ }^{167}$

These practical aspects of Jainism, to users of fly-spray and head-lice killing shampoos, may seem bizarre - but imagine how barbaric and unspeakably vile such products must appear to the Jain. Furthermore, Jain practices have to be seen in the context of a world-view, a philosophical setting.

Before we look to the justification of non-harm as a principle, we need to work our way up from the philosophical ground. That is, we must examine the ontological outlook of Jainism. Jainism derives its ontological viewpoint in much the way that some claim Buddhism tends to, from an enhanced empiricist epistemology. The enhancement to what is normally considered 'empiricist' derives from what a Westerner might call 'gnosis', but what we might more cautiously term 'spiritual experience' or 'ascetic-meditational experience'.

In assessing the nature of the world, Jains seem to go some way along the same path as early Buddhists in their rejection of Hindu ontology. This is common amongst śramana movements, but nonetheless significant. The substantialist 
view, attributed to much Brahmanic philosophy and cosmology, is rejected, but so is the non-substantiality of the Buddhist anatta doctrine, as Dasgupta comments:

They held that is was not true that substance alone was true and qualities were mere false and illusory appearances. Further it was not true as the Buddhists said that there was no permanent substance but merely the change of passing qualities, for both these represent two extreme views and are contrary to experience. ${ }^{168}$

Here we again find the discourse of the 'middle-way' beyond the borders of Buddhism. This ontological position ${ }^{169}$ is not straightforward, and I do not intend to even try and give a full account of it here. Change is incorporated in the Jain view, but its relation to that which changes is seen in three ways. During change, some aspects/elements ${ }^{170}$ remain unchanged; other, new qualities come into being; and other qualities cease to be - are destroyed. This can be illustrated via the image of a clay jug and its formation from a lump of clay:

Thus when a jug is made, it means that the clay-lump has been destroyed, a jug has been generated and the clay is permanent, i.e. all production means that some old qualities have been lost, some new ones brought in, and there is some part in it which is permanent. ${ }^{171}$

This is not the place to offer a full critique of this position - tempting as it is when Dasgupta describes it as:

A reconciliation of the two extremes of Vedāntism and Buddhism on the grounds of common-sense experience. ${ }^{172}$

The Jains develop a complex and often subtle metaphysics on the basis of this ontology, but we must move to one of their more well-known areas to find material of relevance here - their views on karma.

While, as is widely recognised, Buddhism places the generation of karma very firmly in the context of intention, ${ }^{173}$ Jainism often seems more concerned with the nature of the act itself:

According to Jaina teaching it is more the actual process of one's actions than the underlying good or bad will which determines the kind and amount of karmic matter being drawn onto the soul by the respective deed. ${ }^{174}$

Here we see an important idea. It does often seem to be true that Jainism privileges, in the formation of karma, acts over intentions - leading to less of a prime concern with desire. Nonetheless, attachment is still seen as a source of potential suffering. 
In relation to the objects of sense-pleasure, we find Jainism not too far from a Buddhist view. Of 'Masters', ${ }^{175}$ Herbert Warren writes:

He has no liking (rati) for this, that, or the other thing; that is, material objects. He is always in a state of internal bliss whether the object is there or not. Also, liking an object, a cushiony seat, for instance, would be a source of displeasure at its loss. It is ATTACHMENT to sensation that is the point here as a failing. ${ }^{176}$

The omniscient Master is also, in Warren's view, in an interesting state regarding desire. He claims that:

He has perfect control over desires; over any desire to please or indulge the eye, the ear, taste, touch or smell. ${ }^{177}$

What is intriguing is that such a being still has desires; desires still seem present, or capable of arising, but cause no problem as they are under the control of the Master. Elsewhere, however, we also find the notion of the spiritually successful individual portrayed in contrast to the possession of desire, as in the Ácārāinga Sütra at 1.2.2:

Those who are freed (from attachment to the world and its pleasures), reach the opposite shore. Subduing desire by desirelessness, he does not enjoy the pleasures that offer themselves. Desireless, giving up the world, and ceasing to act, he knows, and sees, and has no wishes because of his discernment; he is called houseless. ${ }^{178}$

This passage not only shows a concern with the ending of desire - but also is intriguing in the context of the preceding Hindu ideas. In contrast to the later compatiblism of the Gitta, the lack of desire is here equated with 'ceasing to act'. There seems little in Jainism of the idea of 'desireless action', as 'action' appears to be as problematic as desire. Nonetheless, we do find desire regularly cast as something to be avoided within Jain sūtras. In the Ācārānga Sütra, at 1.6.5, we find desire as problematic and to be left behind:

Thus a man who exerts himself, and is of a steady mind, without attachment, unmoved (by passion) but restless (in wandering about), having no desires, should leave the life of an ascetic. ${ }^{179}$

At Ācārānga Sütra 1.2.4, we see this attitude to desire again, but with an interesting extra dimension:

Wisely reject hope and desire, and extracting that thorn (i.e. pleasure) thou (shouldst act rightly). ${ }^{180}$ 
While the rejection of desire seems familiar, the idea that 'hope' needs rejecting seems at odds with the Buddhist view, until we see the Prākrit terms involved:

āsam ka khamdam ka vigimka dhīre. ${ }^{181}$

Here the term àsam is akin to the Pali $\bar{a} s a$ - which as we shall see in the next chapter - is given by the PED as: 'expectation, hope, wish, longing, desire'. ${ }^{182}$ This is a sense of hope with specific connections with the notion of desire. Indeed, the Sanskrit equivalent $\bar{a} s^{\prime} \bar{a}$ is described as 'wish, desire, hope expectation', ${ }^{183}$ reinforcing the idea that it is only a certain sense in which 'hope' is to be rejected. Reassuring, perhaps, that we need not abandon hope in all respects.

Desire (or more accurately, our response to desire, preferably avoiding it) though is part of the process of escaping or defeating karma, for this is the prime concern in Jain thought. The regular references to abandoning desire in Jain sütras are often accompanied by injunctions to abandon either action in general, or more specific kinds of acts that are seen as particularly karma-generating, such as acts which bring about harm to others:

A person who is without desires and does no harm unto any living beings in the whole world, is called by me 'unfettered' 184

We see, in Jainism, lack of desire as part of the development of indifference, which seems similar - if not identical - to Buddhist ideas of equanimity (which are discussed in Chapter 3). In the Kalpa Sūtra (line 118) we see Mahāvīra described in this manner:

He was indifferent alike to the smell of ordure and of sandal, to straw and jewels, dirt and gold, pleasure and pain, attached neither to this world nor to that beyond, desiring neither life nor death, arrived at the other shore of samsāra, and he exerted himself for the suppression of the defilement of Karman. ${ }^{185}$

The most interesting thing to note here is that the 'indifference' recommended is seen in a certain sense as functional. Lack of desire is part of the process that leads to the end of Karman. That the goal is the removal or lack of karman is clear throughout Jain sūtras, as at Ācārànga Sütra 1.7.8, where the mendicant's lot is being described:

He should not long for life, nor wish for death; he should yearn after neither, life or death.

He who is indifferent and wishes for the destruction of karman, should continue his contemplation. ${ }^{186}$

Alongside these general rejections of desire, seeing it as something to be abandoned en route to the end of karma, we do find that desire is sometimes 
seen as part of the path to this very goal. Drawing on the Tattvārtha Sütra, Padmanabh Jaini lists the sixteen forms of action which help move us to developing a 'tīrthankara-nature', ${ }^{187}$ number 5 of which is 'intense desire of emancipation'. ${ }^{188}$

This discussion of desire in Jainism needs to be seen in the context of the semi-materialist conception of karma in Jainism. Karma is seen as a kind of 'dust' which is generated by action. ${ }^{189}$ As Arvind Sharma writes:

Reincarnation results from the fact that the soul is weighed down by karmic particles, otherwise it would naturally ascend to the top of the universe. ${ }^{190}$

These particles, this dust, is the primary obstacle to liberation, and desire is to be understood in this context. Action can be seen as drawing these particles towards us. The particles are there already, as Jaini explains:

Karmic matter is said to be 'floating free' in every part of occupied space. ${ }^{191}$

In this world, with karma all around us, action is seen as a form of vibration which attracts karmic dust:

The vibrations referred to here actually denotes the volitional activities of the individual. ${ }^{192}$

So far it seems that action alone is the source of our karmic particles. But once the particles are drawn towards us, it is here that desire begins to play its role. A soul, or jīva, will escape or be enslaved by these particles drawn by the vibration of action depending upon its 'desire-status':

Vibrations alone, however, do not produce bondage. The karmic 'dust' which they draw to the soul would simply fall away were the soul not 'moistened', as it were, by its harboring of the passions (kașāyas): desire (rāga $)$ and hatred (dveșa). ${ }^{193}$

This is a useful explanation. We can see here both why there is a primary concern with action, but also why desire is problematic, if not the foremost concern in Jain thought.

In Jain thought we have seen desire as an obstacle to liberation, but some types of desire - the desire for liberation itself - are seen as acceptable, even vital. This typology is not developed to any great degree, for it remains secondary to the Jain concern with the karmic results of action. This derives from the conception of karma in Jainism that divorces it from the Buddhist view of karma as mind-generated. It is also worth noting, as this applies to some issues that will arise in Chapter 4, that Jainism shares some of the Buddhist concern with the 
problem of attachment to 'views'. While amüdhadrṣti - freedom from delusive views - applies to specific types of incorrect views, ${ }^{194}$ it is worth mentioning the description of 'correct view' that P. Jaini gives in a footnote:

Attainment of the 'correct view' is thus not an accretion of something external to the soul; rather, it is the unfolding of 'true vision' in the soul. ${ }^{195}$

This is interesting in relation to the Buddhist notions of 'direct-seeing' that are discussed in Chapter 4.

\section{Conclusion}

One issue, which I have left until this point to address, is whether or not we can locate a 'paradox of desire' in Hinduism. In the introduction we saw the idea of such a paradox in Buddhism, and it would seem that any tradition preaching a doctrine of the abandonment of desire is going to have similar problems. Does one desire a state of desirelessness?

We have seen that one whose desire is only for the Self is often classed as one without desire - so it may be that the desire of this sort does not count as the type of desire that we are to overcome.

This classifying of desires is, as I stated earlier, found only implicitly most of the time, and there is no overt typology of desire that runs throughout Hinduism. However, the extraction of such a position from the texts seems reasonable, and is persuasive. This may help to rescue Hinduism from accusations of the aforementioned paradox. To demonstrate this, Killingley looks at Bhāgavata Purāna 2.3.10:

One who is without desire, or who desires everything, ${ }^{196}$ or who desires salvation with exalted thought, should worship God with intense discipline of devotion. 197

Here the devotee without desire is the one who desires salvation. Killingley explains how, in his view, this helps escape the notion of a paradox of desire:

Here again we may regard these descriptions as three alternative attempts to describe the same kind of person, rather than as descriptions of three kinds of person who are qualified for the highest form of worship. Thus desire for salvation is no desire; otherwise, the desireless state on which salvation depends would be unattainable. ${ }^{198}$

So, it seems clear here that the strategy is to give a special status to the desire for God (in later, more theistic texts such as the Purānic ones) or the Self (in earlier, particularly Upanișadic texts) - making it equivalent to a lack of desire. 
This is an effective strategy, but is it defensible? How do these condemnationexempt desires differ in terms of structure and effect from those with more worldly objects? The obvious answer is that these desires can be satisfied. Unlike the worldly desires that are doomed to frustration, desires for the Self or God, for the atman or Brahman, can be permanently fulfilled. In this way the desire is ended because it is satisfied in such a manner that it can arise no more.

Another aspect of explaining this matter is the idea that these desires - for $\bar{a} t m a n$ and/or Brahman - are desires that take us beyond the realm of māya , of multiplicity. This will be pursued as I now consider how the end of desire is seen as equivalent to the attainment of liberation.

Why is freedom from desire associated with liberation ${ }^{199}$ or salvation? If we consider that the goal of much Hindu thought is to achieve - or come to know the unity of the ätman with Brahman, we can see that the goal is to end individuation, to re-merge with the primordial divine essence. If desire is what causes differentiation - through being a cause of rebirth, as well a force that caused the creative act - then desire is the source, as mentioned earlier, of individuated being. As Killingley writes:

What makes kāma a bar to salvation is that it is concerned with the world of multiplicity. ${ }^{200}$

Salvation is then the reversing of the creative process at $\mathrm{Rg}$ Veda 10.129 .4 , the extinction of desire causing the other to become part of the One. Dermot Killingley makes this clear in his analysis of kāma:

kāma is the necessary impulse for the creation of the world. It is kāma, in other words, which initiates the transition from a unitary absolute being to the world of multiplicity. The way to salvation is the reverse of the cosmogonic process, and thus requires the abandonment of kāma. ${ }^{201}$

This makes sense, but even desire for no desire is in terms of kāma - making, as previously stated, the typology limited and shrouded in complex imagery and ritual.

I wish to conclude by raising a number of issues that will crop up throughout the next two chapters, where I examine Buddhist approaches to desire.

Why is desire so dangerous? Clearly it is powerful, especially in the context of being the means by which the universe came into being. Its power then is hard to control, but beyond this there are other reasons to be wary.

Desire leads to frustration if unfulfilled - and given the nature of the world we inhabit, this is all too likely an outcome. Beyond this however, unregulated desire can be seen as dangerous in another way. If our desires are not for the Self or God, then they can be seen as reinforcing the subject/object distinction - that between the desirer and the desired. This distinction is one that much Hindu thought would 
encourage us to overcome. ${ }^{202}$ Non-God/Self directed desires seem predicated on the implicit belief in such a distinction. In this way, desire binds us to the samsāric world of $m \bar{a} y \bar{a}$.

In Jain thought we saw the problem of desire in a distinctive manner - making our jīva moist and susceptible to karmic particles. While the treatment is distinct from Hinduism, it maintains the idea that desire is a force implicated in our remaining in samsāra. Desire emerges, then, as an agent of bondage. The relationship between desire and freedom is explored more in detail in Chapter 5.

One of the most forceful images to emerge in this chapter has been the necessity of our response to desire - we have no choice but to respond to the upspring of desire we encounter within ourselves.

It would seem that, in many ways, desire 'comes upon us'. From the $\mathrm{Rg}$ Veda to ideas of Kāmadeva, we have seen desire personified and externalised. We might read this as a psychological strategy for articulating the experiential reality of desire. It feels like this thing beyond us. As such, we cannot - in the first instance - choose to be without desire. This lack of desire may come later, but first we must deal with the reality of desire.

So, we are faced with the situation of having to decide what to do in the face of desire. Earlier in this chapter I characterised the Hindu range of recommended responses with the idea of desire as a beast - one we can choose to try to tame, ride or kill. In one sense, this is simplistic, but in another it captures something of how Hinduism sees desire.

The Käma Sütra seeks to regulate desire; it is placed firmly in the context of the householder āśrama, integrating desire into life while preventing the worst of its consequences. This we could see as a taming of the beast.

The renunciant approach could be seen as incorporating aspects of both riding and killing. To 'kill desire' is to bring about its total removal - to be free of desire. We have seen this as an important motif in Hindu thought. Alongside this, the desire for the atman or for God has been seen as equivalent to the lack of desire. We can see this as 'riding' desire. By re-orientating desire, we harness its power; we use its force and by riding it we are able to control its direction. This is to steer desire to spiritually wholesome destinations, which themselves can be seen as the end of desire. If we are able to ride desire, we are able to use it as a vehicle which is then conveyed to its own destruction. ${ }^{203}$

In Chapter 3, I seek to discover if we can find a comparable range of responses in Buddhist thought. Furthermore, I follow ideas discussed here on desire as powerful and creative. We find in Buddhism a religion which, arguably, seeks to do without much of the metaphysical speculation found in Hindu thought. In such a context, is there room for a notion of desire with the same cosmological significance as in Hinduism? In seeking to answer this question, I hope to not only discover the range of responses to desire found in Buddhism, but also indicate its arising in a way that Hindu thought does not.

Hinduism lacks a fully worked out theory akin to the notion of paticca-samuppāda that is found in Buddhism and so seems less able, or maybe less willing, to 
explain the manner by which desire comes to be. It may be that it has no need to do so, especially if viewing desire in terms of metaphysical principle. Buddhism, devoid of such 'grand narratives' of cosmology, has perhaps been dialectically forced to engage more with the roots of desire. Furthermore, as we shall see, Buddhist understandings of the nature of spiritual practice are predicated on a need to understand causality - therefore enabling the practitioner to intervene in causal processes. The arising of desire is just such a causal process, and we now move to see not only the nature and status of desire in Buddhism, but also how we might respond to it. 


\title{
BUDDHISM AND DESIRE
}

\author{
The varieties of desire
}

\begin{abstract}
Through many a birth I wandered in samsāra, seeking, but not finding, the builder of the house. Sorrowful is it to be born again and again.

O house-builder! Thou art seen. Thou shalt build no house again. All thy rafters are broken. Thy ridge-pole is shattered.

My Mind has attained the unconditioned. Achieved is the end of craving. ${ }^{1}$
\end{abstract}

\section{Introduction}

In Chapter 1 we saw how much Western thought characterised desire in terms of lack or absence. This became, in the argument, linked to the notion of desire as something negative, disturbing and possibly to be avoided. Alongside this were powerful counter-currents of thought which were not only less judgemental regarding desire, but that also saw it as powerful and creative.

The notion of desire as creative was reinforced considerably in Chapter 2, where we saw Vedic texts placing desire as part of their cosmology. Throughout the second chapter, though, two key questions kept returning. First, while the religious seeker was regularly exhorted to avoid worldly and sensual desires, the desire for the Self (as $\bar{a} t m a n^{2}$ ) was encouraged. However this desire for the Self (which is equivalent to the desire for brahman, and in later more theistic texts for God) was often described as having no desire, as being desireless. While attempts were made to resolve this tension - how desire for the ultimate could also be legitimately described as an absence of desire - there was no clear and coherent typology of desire. I wish to investigate in this chapter the extent to which Buddhism does offer this kind of typology.

Second, it was asked at numerous points - and this is closely intertwined with the preceding point - whether what was really called for was the elimination of desire, or its purification/modification. Before asking what the Buddhist answer to such a question is, we need to consider whether the question itself makes sense within a Buddhist context. Why do we need to be so cautious? Well, loaded questions are clearly something we should always be wary of, but there are also special 
circumstances here. To ask the same question, and to expect a coherent answer, of the two religions must be done, if at all, with the recognition that despite surface similarities, at a metaphysical, particularly ontological, level, they have very different world-views.

\section{Which Buddhism?}

The reasons for limiting the scope of this book with regard to Buddhism are given in the Introduction, but I will mention here briefly the rationale for this approach. Other than obvious considerations of size, I find in the Canonical Pali texts of Theravāda Buddhism a distinctive discourse on desire. While there are tensions, these are considerably less clouded than in many later texts. ${ }^{3}$

While my overviews of Western and Hindu material have been wider in scope, I here need a tighter focus. I propose that out of a dialogue between the message of the Pali Canon and the understandings of desire found in Chapters 1 and 2, we come to a more sophisticated, richer and potentially therapeutic conclusion. Limiting myself in this way is, of course, a double-edged strategy. The texts of Mahāyāna Buddhism say things of considerable interest, but setting them to one side allows the clarity of focus necessary for the proper examination of those texts I am using.

\section{The redirection of desire}

If we recall the Hindu view that desire needs redirecting to its proper object, we find three ways of describing this object (though in an ultimate metaphysical sense much, though not all, Hindu thought would say that they are, in the final analysis - beyond Māya - the same thing). Proper desire, which as we saw may not even count as desire, ${ }^{4}$ can be that for the Self (the àtman), for Brahman (albeit normally via desire for the Self), or directed at God. Now, if we ask whether the Buddhist position can also countenance such a redirection of desire as a form of quelling or quenching more troublesome forms of desire, we are not likely to get far. Clearly, Buddhism is unlikely to recommend redirecting our desire in any of these three directions.

First, the anatta teaching of early Buddhism is in direct contrast to the Brahmanic belief in the attman. No atman can be found and hence any desire directed towards it is going to end in $d u k k h a .^{5}$ The quest for the inner-Self is fruitless, from the Buddhist perspective. Here desire of the sort found in Hinduism cannot be fulfilled. Were there an ätman then things would be different; there would be a stable, reliable unchanging component of reality - desire could be sated. In the absence of such an ätman, such desire is necessarily doomed to frustration. One might be tempted to speculate that nibbāna is able to provide a suitable replacement for âtman-brahman as an ultimate object of desire. Clearly nibbāna varies in that it lies outside the world ${ }^{6}$ (whereas in some senses, 
Brahmam is the world), but I will return to the question of desire for nibbanna shortly.

Second, desire for the divine brahman - the ground of all being - is likewise pointless and harmful. Pointless for the same reason that a desire for the àtman is because no such thing can be found. The universe, in the Buddhist view, lacks such a metaphysical ground. Things are not the way they are due to their being manifestations of a divine essence, they just are. While this does make Buddhists sound a little like Sartrean existentialists, I feel it accurately represents the ontology of the Pali Canon. Of course, the coming into being of phenomena is not just a matter of random manifestation - but relies on the process of paticca-samuppāda. Things arise due to conditions, but this theory requires no external ground of being.

Finally, what of desire directed at a personal God - such as we saw with Kṛ̣na in Chapter 2? Maybe here we can see a redirection of desire that Buddhists can approve of. Buddhism does not deny the existence of devas, but these are seen as within samsāra - they have relatively little to offer the spiritual aspirant. But might there not still be a suitable focus for desire in the Buddha himself? After all, is there not veneration of and devotion to the Buddha? Indeed, but we would be grossly mistaken were we to take the Buddha for a god, particularly for a deity in terms of calling for devotion like that to Krșna. While devotional acts are directed at the Buddha, the pre-Mahāyāna view is that the Buddha - after his parinibbanna - is beyond contact with the world. ${ }^{7}$ The precise status of a tathāgata after death is a topic examined at numerous points in Canonical texts, ${ }^{8}$ but whatever else is said, the Buddha is not a being with the attributes necessary to make him an appropriate object of desire.

If, beyond death, the tathägata is not a suitable object of worship and desire, ${ }^{9}$ we might ask if he was appropriate as such an object during life. There are, in the Canonical texts, those who are said to have attained nibbanna through faith in the Buddha. Even here though, faith is not to be necessarily taken as equivalent to desire. One can offer a teacher respect, pay them homage even, ${ }^{10}$ and have trust in his or her message - but these do not amount to desire for the Buddha. Whether these kinds of feelings constitute a desire to be like the Buddha - to be enlightened - is another matter, and will be addressed later.

Furthermore, we might ask, if the Buddha is not an object of an appropriately redirected desire - might not something else be? Here we should perhaps consider two potential candidates. First, the Dhamma (the teachings) and second, the gods which Buddhism does seem to accept as existing. The Dhamma, in the sense of the truth of the Buddha's teaching, ${ }^{11}$ might seem an ideal object for a modified and redirected desire. A passion for knowledge seems a worthy enough thing. Here we need to be careful. It is just on topics such as this that confusion over the Buddhist view on desire can easily emerge.

A striving after religious knowledge is something Buddhism is renowned for - it is a notably scholarly religion. On the other hand, we are warned against attachment to views and unnecessary disputing. ${ }^{12}$ It would seem that we may need 
to make a distinction between an acceptable wish to comprehend, a desire for knowledge; and a grasping after understanding - which is harmful and seeks knowledge in a way damaging and dangerous to the seeker. Also we need to be

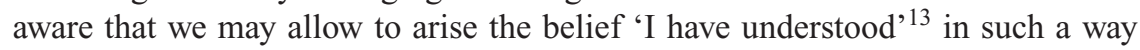
that it closes the possibility of further understanding.

Already we can begin to see the emergence of desire as not straightforward. There are not just differing objects of desire by which we can judge our wants. There are ways of wanting, and this is a key aspect of what is explored in this chapter. Desire is a complex multivalent phenomenon, and Buddhism recognises this, and throughout this chapter we shall see not only this recognition, but, of equal if not greater importance, the response to this recognition.

The second candidate here is the gods. Buddhism does not deny the existence of the gods of Brahmanic belief. We can be clear on this, for in the suttas the Buddha even enters into discussion with such beings. For example, in the Ariyapariyesana Sutta $^{14}$ we find the Buddha in conversation with Brahmā Sahampati. ${ }^{15}$ This discussion is a useful one though, for it demonstrates the fact that the Buddhist approach to the Brahmanic gods varies from the Brahmanic view of them. For the Buddha, the devas (and indeed devis) are not manifestations of ultimate reality, nor are they omnipotent, omniscient and omnibenevolent. ${ }^{16}$ In the Ariyapariyesana Sutta, the appearance of Brahmā Sahampati seems to be, in part, a rhetorical strategy for establishing the Buddha's superiority over such beings (Brahmā Sahampati pleads with the Buddha to teach Dhamma to the world). ${ }^{17}$ The gods are inside samsāra, not beyond it - they are mortal and at some point, long-lived though they are, will die and be subject to rebirth according to the quality of their kamma. They are limited, finite, transient beings such as ourselves - they too are subject to the three marks of conditioned phenomena (anicca, dukkha and anatta), so they can suffer dissatisfaction and anxiety $($ dukkha $){ }^{18}$

Perhaps most vitally in the current context, the devas are subject to anattathey lack an ätman. If they lack ātman this implies that they lack also the features of Brahman. This clearly not only prevents them from being properly considered as 'ultimate beings', but would seem to also make them ineligible for consideration as appropriate objects of redirected desire. This does not mean that practising Buddhists never venerate or offer acts of devotion to these, and other, limited but powerful beings. There, in practice, has often been a co-existence of Buddhist belief and:

forms of religious thought and practice which centre on rituals aimed at gaining some benefit or avoiding some threatened harm from local gods, spirits, and so on. ${ }^{19}$

These gods and spirits may be subject to anatta, but they are no less (and of course, no more) real and substantial than we are. ${ }^{20}$ Despite these practices, being anatta means that the devas have no permanent essence or substance. Like us, the devas are nothing but a stream of temporary conditioned phenomena. ${ }^{21}$ 
As well as being unsuitable as objects of our desiring, the gods themselves are subject to their own ignorance-based desires, leading them to dukkha. In the Sarigiti Sutta ${ }^{22}$ we hear of the gods' desires:

There are beings who desire what presents itself to them, and are in the grip of that desire, such as human beings, some devas, and some in states of woe. ${ }^{23}$ There are beings who desire what they have created,... such as the devas Who Rejoice in Their Own Creation. ${ }^{24}$

Here we see the kamma-loka gods as in possession of desire. The above list is clearly not comprehensive, but we see the desirous nature of the devas. The desire of these devas is clearly qualitatively distinct from the 'desire-of-the-Self-foritself' that we saw ascribed to the Self (and therefore Brahman) in Upanisadic texts in Chapter 2. Desire for the gods, who are beings that themselves desire, from a Buddhist perspective, is, then, not going to be a salvific reorientation of our desires, for they represent, and are affected by, the features that lead us from desire to frustration, such as anicca and anatta.

\section{Desire and nibbāna}

I have deliberately left till the last another possibility, a possibility whose features are more complex, and whose relation to desire will be a key theme throughout this chapter: Nibbāna. Should we not desire nibbāna? After all, it is posited as the ultimate goal of Buddhist thought. ${ }^{25}$ It is always there, at least in the sense of always being available. Nibbāna is neither anicca nor dukkha, although it is made clear that it is not a Self, lacking the features ascribed to the ätman. As Peter Harvey writes:

While Nibbāna is beyond impermanence and dukkha, it is still notself... While Nibbāna is beyond change and suffering, it has nothing in it which could support the feeling of I-ness; for this can only arise with respect to the khandhas, ${ }^{26}$ and it is not even a truly valid feeling here. ${ }^{27}$

I mention this not only to clarify the notion of nibbāna (although a little more will be said later in the chapter on the nature of nibbāna), but also to show that desire for the Self is not identical with desire for nibbāna, as they do not share all of the same features.

Nonetheless, nibbāna is beginning here to look more appropriate as an object of desire. It is not anicca - it is permanent, something reliable to point our longings at. It is not $d u k k h a-$ something which is in itself the end of suffering is surely desirable. Buddhists are directed at nibbāna, as this is the goal of the path; as Kalupahana writes of nibbāna, it is 'the goal or summum bonum of early Buddhism'. ${ }^{28}$

If we can reject the previous candidates for truly desirable objects of our desires without too much trouble, this one is not so easy to deal with. ${ }^{29}$ Buddhists 
should want nibbāna; it is the concept which stands between Buddhist philosophy and the charge of pessimism, as it balances the emphasis on $d u k k h a{ }^{30}$ The world may be a place devoid of any inherent purpose or meaning, but the existence and reality of nibbāna is what ultimately prevents the Buddhist weltanschauung from being a form of nihilism. ${ }^{31}$

I shall return, later in this chapter, to the issues caught up with the desire for nibbāna. However it is clear that there are serious issues to be addressed here. We are going to have serious problems if we wish to say that Buddhism would have us remove all desire - for we should surely desire the desireless state that is nibbāna.

It is confusions over this very topic that lead to worries, as we saw in the introduction, over there being a 'paradox of desire' in Buddhism. This will not be resolved by just establishing a hierarchy of desire on the basis of the objects of desire (desire for nibbāna being 'better' than desire for a cigarette, or even the desire for a nice cup of tea). There are two reasons for this. First, even the desire for nibbāna needs to be relinquished in order to obtain nibbāna ${ }^{32}$ - a final letting-go in order to pass through the door to the deathless. Second, two people can want the same thing in different ways. Our desires can be motivated differently - surely the desire for a drug to relieve acute pain is qualitatively distinct from someone's desire for the same drug for recreational purposes. Furthermore, as will be made clearer as this chapter progresses, it is more than motivation; distinctions need to be made between a 'grasping' kind of desire and a calm wish for something.

It is worth noting here that the nature of nibbāna remains a controversial area within Buddhist studies. Grace Burford argues that the standard Theravāda understanding of it, particularly as understood in the Abhidhamma, represents a change from the early Buddhist position, and that this moves it away from us as a goal, making it into a form of metaphysical principle:

The Abhidhammists transformed Theravāda Buddhism by removing nibbāna from the causal realm altogether. As Macy ${ }^{33}$ points out, if nibbāna is treated as entirely unconditional, then it loses its relevance to the world in which we live. She concludes that the tendency to equate nibbāna with a metaphysical absolute renders the goal inaccessible to the very beings who need it. ${ }^{34}$

I think she, and Macy, commit a possible non sequitur here. Why does understanding nibbāna as wholly unconditioned automatically render it as a metaphysical absolute? This is not wholly clear. In some senses, it is metaphysical thinking that stands between us and nibbāna. It is the ways in which nibbanna is distinct from the Hindu notion of Brahman that mitigate against it being viewed as this absolute principle of the universe. Nibbāna is not a ground-of-being, nor is it a self-subsistent essence, but as unconditioned it is differentiated from that which is dukkha and anicca; to be conditioned is to be inevitably subject to these two of the three marks. ${ }^{35}$ 
I see why Burford wishes to make nibbāna relevant to those who practice kammic Buddhism (to use Spiro's distinction, as she does to an extent). ${ }^{36}$ However, for me the unconditioned nature of nibbāna does not drain it of its relevance as a notion in the here and now. While I sympathise with her wish to make Buddhism focus on the way our present lives can be transformed, the existence of an unconditioned can, in my view, contribute positively towards this.

To conclude what has been said in this section, we can clearly see how Buddhist thought differs from a Hindu approach. While both seem to call for an ending to desire, the Hindu idea of redirecting desire at a suitable goal - of possibly using desire as a vehicle of salvation - is radically different. The metaphysical basis of Buddhist thought - arising from the anatta doctrine - is such that the desire for the àtman, for Brahman, for a theistic deity, all these are routes to $d u k k h a$ rather than liberation.

In a way, we can understand the Buddhist position on these objects of appropriate Hindu desire in the context of a term from the first chapter - as a 'lack'. The universe is in 'lack'; there is an absence of proper objects of desire ${ }^{37}$ within the universe. ${ }^{38}$ Desire has to be, then, understood in the absence of an attman, Brahman or ultimate deity. This feature of reality - the metaphysical emptiness of the universe - structures Buddhist thought about desire in just as influential a manner as does the Hindu view of desire as tied in with the basic fabric of the universe (and indeed what causes the universe to come about). Regarding the world, we can see that Buddhism proposes an ontology of lack, the world being empty of Self and what pertains to notions of Self. Being - individual and cosmic - is empty, lacking svabhāva. ${ }^{39}$

This is significant for the way I look at desire in this and Chapter 4. Desire is not to be seen as just that feeling one gets when one wants something. While not being described so often as integrated into the very fabric of reality as in Hinduism, we still need to assess desire in a broad metaphysical sense. Desire is a force which acts in a creative, even world-of-experience-making, manner.

This means that, in order to draw overall conclusions, desire must be initially examined in two ways, with the goal of assessing it in a third manner. (1) Desire, as we experience it as individuals, must clearly be considered. How do our desires come about within consciousness, how do they arise? I will attempt to answer this question in both this chapter and the next. Here I examine the nature of the ways of desiring, the varieties of wanting. In Chapter 4, I look at these desires in the holistic context of Buddhist psychology ${ }^{40}$ and through the way Buddhism understands the mind-body relationship. (2) Desire needs, as stated above, probing with regard to the overall structure of reality. (3) Examining desire in these ways will allow me to make judgements with regard to the kusala-status of desires. This third component is vital, for here we shall find an answer to the question of what we are to do about desire. Armed with insight into the mechanics of our desiring we can use these kusala judgements to guide us in undertaking interventions in these patterns of interaction. 


\section{Desire and the Buddha}

Before we move on to look at the terms used in Pali texts for desire, I wish to take a little time to ponder on whether the accounts of the life of the Buddha can demonstrate anything with regard to the Buddhist view of desire which he formulates after his attainment of nibbāna. I am not here commenting on the historical accuracy of such accounts, rather on their rhetorical power in helping establish the Buddhist discourse on desire.

Clearly the accounts of the life of the Buddha show an overriding concern with dukkha. This is best illustrated via the episode of the 'four sights', ${ }^{41}$ where faced with the reality of old age, sickness and death - and finally a paribbājaka - the Buddha goes forth from home into homelessness. The importance of dukkha within Buddhist thought is hard to overestimate. At M.I.140, in the Alagaddupama Sutta, the Buddha offers a summary of his teaching:

Both now and in the past bhikkhus, what I set forth is dukkha and the cessation of dukkha. ${ }^{42}$

This is at the heart of the message of early Buddhism. It is the motivation of the whole Buddhist project. However, we can get a sense of just how pivotal desire is within this project, and one way to do so is through a certain reading of the life of the Buddha. During his life prior to the 'four sights' and his renunciation, Gotama lived a life free from obvious want: all his needs were provided for. Indeed accounts ascribe him a sheltered and cosseted existence. ${ }^{43}$ Other than demonstrating his noble lineage, such accounts present an image of someone who was in the rare position of having most - if not all - of their worldly desires fulfilled.

In the absence of awareness of ageing, sickness and death, there was less reason for certain types of desire that other humans are subject to. ${ }^{44}$ The first three of the 'four sights' represent not only an awakening of compassion, ${ }^{45}$ but also - and this is what is vitally important - a realisation that his own desires would not always be fulfilled. It is not just the presently sick, dead and old people he sees who are subject to suffering. The realisation must have dawned on Vipassī/Gotama that he too, contrary to his previous beliefs, would not always have all his desires fulfilled. Sickness, old age and death come to us all as unwelcome visitors, and the young Gotama - sharp minded as we are informed he was was now in possession of disturbing knowledge. We can see this demonstrated in the Ariyapariyesanā Sutta (the Discourse on the Noble Quest) where the Buddha describes the thoughts prompting his renunciation:

Suppose that, being myself subject to ageing, sickness, death, sorrow, and defilement, having understood the danger in what is subject to ageing, sickness, death, sorrow, and defilement, I seek the unageing, unailing, deathless, sorrowless, and undefiled supreme security from bondage, Nibbāna. ${ }^{46}$ 
Here the Buddha describes these thoughts, and in them, we can see his awareness of his own peril at the hands of ageing, sickness and death, and the urge to transcend them. This does not make him selfish, but is a coming to be aware of these universal afflictions. ${ }^{47}$ Furthermore, and this is speculative but consistent with Buddhist thought, in order to make effective his compassion, the realisation of the futility of desire and the inevitability of frustration is a necessary factor.

The other incident related to desire that we can see in the life of the bodhisatta prior to his enlightenment is also related to the very antithesis of desire - renunciation. When Gotama goes forth, leaving behind his wife and son, he is not free from all desire. Far from it, he has a new wish, a new goal to strive toward. He is now a seeker after religious knowledge. He goes to Ālāra Kālāma as one desirous of learning, ${ }^{48}$ and after passing through all the available teachers and surpassing them, completes his search after looking at the grove at Senānigama, ${ }^{49}$ deciding that such a place is appropriate for his final efforts, and proclaims:

Indeed, then bhikkhus, there I sat down [thinking]: Here is a proper place for striving. ${ }^{50}$

Here we see the bodhisatta about to engage in spiritual exertions. Clearly, striving (padhāna) can be considered to require an element of intentionality that one could describe as desire - or at the least, as 'goal-based'. What is obvious though (the term padhāna will be discussed later in this chapter) is that Buddhism is not a form of withdrawal from, or renunciation of, all mental activity. It is not a form of quietism. Indeed, it is mildly disturbing that Mrs Rhys Davids' words, from just over a hundred years ago, still seem relevant here:

There is, for instance, much that is misleading, or downright false, in labelling Gotama's doctrine as Pessimism, Pantheism, Atheism, Nihilism, Quietism, or Apatheia. ${ }^{51}$

Buddhism is a vibrant and dynamic engagement with the realities of desire, whereby it does indeed seek to help us be still and calm, but this is for the purpose of clarity of thought. Furthermore, the still and calm is far from immediate and may require the exertion of significant energies to achieve. To seek to withdraw from all mental activity would be, it seems to me, to move away from a middle-way towards the desire for annihilation. As we shall see, the Buddhist spiritual renunciant may have renounced much, but the remaining inner-task is an arduous one, requiring of great energy and exertion. ${ }^{52}$

\section{The varieties of desire}

One possible source of confusion when looking at desire here relates to issues of translation. There are in Pali, as in English, a great number of terms for desire. These terms represent a broad range of shades of meaning, some with ethical connotations and some without. To examine all such terms in detail would by 
itself exceed the space available (and possibly the patience of both author and reader), but some attention is required. In order, then, to make sense of the usage of these terms, I will now offer discussion on some of the most important terms in the Buddhist understanding of desire.

While I am primarily interested in Pali terms here, some Sanskrit equivalents will be engaged with. So, while looking at Pali terms, I will often examine their Sanskrit equivalents, but this should not necessarily be taken as meaning that the Pali term is directly derived from the Sanskrit one. As Wilhelm Geiger points out:

Pāli however cannot be directly derived from Sanskrit; for it shows a number of characteristic features which suggest its closer relation to Vedic... This has always to be borne in mind when in the following Pāli forms are compared with Sanskrit forms. The former cannot be derived from the latter but stand beside them as later formations. ${ }^{53}$

So, we can make useful comparisons between Pali and Sanskrit forms, but it would be wrong to assume that the Pali flows directly from the Sanskrit, or that the Sanskrit is somehow the 'original' or 'true' meaning of a term. While I do not wish to become distracted by this issue, it is worth reflecting that the goal of 'true' renderings of Pali terms is difficult. The relationship between truth and language is complicated, and not one I have any hope of solving here, but suffice to say that for current purposes I do what I can to view the use of Pali terms in the context of both their usage and, at times, the use of the Sanskrit equivalent.

I shall leave the first till last, as it were. That is, one might expect any discussion of desire in Buddhism to kick off with tanh $\bar{a}$ and perhaps chanda - a term often contrasted with tanh $\bar{a}$. It is tanh $\bar{a}$ that is implicated in the Four Noble Truths, and often seen as an exclusively negative form of desire. However, there is much I wish to say on tanh $\bar{a}$ (and indeed chanda) and I need to do so in the context of these other terms which I shall look at first.

It is interesting, before looking in detail at the key terms for desire, to note that negative and positive mental states are often seen as parallel versions of each other. When mental energy is expended, its direction can, as it were, go either way, and certain positive states are seen as particularly close to certain negative ones. We can see this as a qualitative affinity between two states - they are of phenomenological similarity. We see this with relation to rāga as part of the Visuddhimagga's discussion of temperaments. At Vism. 102 (III.75) we read that:

Herein, one of faithful temperament is parallel to one of greedy temperament because faith is strong when profitable (kamma) occurs in one of greedy temperament, owing to its special qualities being near to those of greed..$^{54}$

Both faith and greed are keen to 'stick to' or latch on to an object - but this can be kusala or akusala, depending on both the object and the manner of the latching. 
We also find, in the Visuddhimagga, that metta - loving kindness - is seen as having an affinity with affection. In Vism. 318 we read, in a discussion of the characteristics of mettā, that:

It succeeds when it makes ill will subsides, and it fails when it produces (selfish) affection. ${ }^{55}$

This closeness between positive and negative forms of emotion or mental state is indicative of the importance given to the way in which we act upon our impulses and the extent to which we need to be wary and mindful when seeking to develop kusala states of mind within ourselves.

\section{The three roots of unskilful action (akusalamūla)}

I begin my consideration of the different ways in which we can see desire within the Pali Canon by looking to rāga, dosa and moha. These are given as the three key flaws of character (the three kiñcanā), the three obstacles, or the three fires (three aggī) - rāgaggi, dosaggi, mohaggi ${ }^{56}$ However, there is also another triad, which is seen as being responsible for motivating negative behaviour - be it of mind or body: the three roots of unskilful action (akusalamūla). This group does not have rāga at its head in the suttas or elsewhere. When given as these three akusala roots - such as at D.III. $214^{57}$ - lobha takes the place of rāga. This leads me to consider lobha directly after rāga, dosa and moha - and from the way the Abhidhamma explains lobha I am able to begin to look at a wider range of terms.

\section{Rāga}

There is no fire like passion, no grip like hatred, no net like delusion, no river like craving. ${ }^{58}$

I have translated rāga here as passion. While its primary non-philosophical meaning is 'colour, hue, colouring, dye', ${ }^{59}$ rāga is usually used in the sense of:

excitement, passion; seldom by itself, mostly in combination with dosa and moha, as the three fundamental blemishes of character. ${ }^{60}$

We might have considered using 'greed' again for rāga, but 'passion' seems an equally acceptable translation. One might worry that 'greed' better conveys more of the negative character usually associated with rāga, but I am not sure it coincides with the Pali usage as well as 'passion'. 'Lust' is effective, ${ }^{61}$ combining something of passion with the negativity of greed, but it seems, to me, too strong a term for many of the uses of rāga in context. However, some might still prefer 
'lust', as I did encounter the view that räga is associated with sexual passion or desire. L. B. N. Perera writes:

Buddhism recognizes man's inherent desire for the pleasures of the senses (kāmacchanda or kāmatanhhā) in which is embodied the more specific trait of sensual passion (kämarāga), which, in effect, is sexuality. ${ }^{62}$

While rāga, as passion, may include this sense of sexual desire, I am not convinced from its usage in the texts that its meaning should be considered as limited to this.

In its Sanskrit use, rāga has the same meaning of colour - especially red, as we might expect given its figurative use - but again its meaning is given in a less negative sense:

Any feeling or passion, (esp.) love, affection or sympathy for, vehement desire of, interest or joy or delight in (loc. or comp.). ${ }^{63}$

This is clearly a more neutral sense, while the Pali usage has become specifically associated with a negative sense of passion. 'Passion' is a word we often tend to use in rather positive ways in English. Describing someone as 'lacking in passion' is not usually a compliment, ${ }^{64}$ and the Sanskrit usage of rāga is somewhat closer to this conception. Nonetheless, for rāga in Pali contexts I feel 'passion' is the closest English can probably come. ${ }^{65}$

A related term of interest here is virāga - the absence of rāga. We can tell just how akusala rāga is by the idea that its negation is equivalent to clearly kusala states. The PED gives virāga as:

Dispassionateness, indifference towards, disgust... cleansing, purifying, Arahantship. ${ }^{66}$

We see virāga positively recommended throughout the Pali Canonical texts, ${ }^{67}$ used to represent a state of calm and the absence of psychological disturbance.

However, while rāga is not going to win any prizes for the most kusala desire form, is its akusala status absolute? It would seem not, for we do encounter the notion of dhammarāga - a passion for the dhamma. In the Atthakanāgara sutta we find it occurring:

[But] If he does not attain destruction of the taints, due to passion for dhamma, delight in dhamma ${ }^{68}$ with the destroying of the five lower fetters, he then becomes one spontaneously reborn, ${ }^{69}$ there attaining final Nibbāna, not to return to this world. ${ }^{70}$

This passage is interesting. It reflects the position of one who has made significant spiritual progress, but who has not overcome all of the $\bar{a} a v \bar{a} s$ - the taints. 
But driven on by a rāga for dhamma they become a non-returner, assured of liberation after rebirth in the Pure Abodes. ${ }^{71}$ Furthermore, it is worth noting that a non-returner has other rāga in addition to dhammarāga. A non-returner still has attachment to/passion for the rüpa and arüpa levels - the pure form and formless worlds, forming two of the remaining fetters. ${ }^{72}$

So while we are not seeing an arahat described as possessing a form of $r a \bar{g} g$ here, we are seeing it as part of a move which ultimately leads to nibbāna. This issue of whether normally akusala states can - if appropriately directed and in conjunction with other powerful kusala cittas and cetasikas - be used to propel ourselves nearer to the spiritual goal will be further addressed when I come, later in this chapter, to look at the term tanhā.

\section{Dosa: the inverse of desire}

Before moving to the next term for desire, it is worth pausing briefly to look at one of the other terms in the triad of ragga/lobha, dosa and moha. Dosa, whether as 'hatred', 'aversion' or 'ill-will' ${ }^{73}$ is the inverse or contrary of desire. I will, later in this chapter, discuss in general whether there are any structural (psychological and metaphysical) similarities between aversion and desire - for both are responses to an object. While one is pulling towards oneself, the other is a pushing away. In the three-fires imagery, neither is helpful to us. Indeed, as will be explored in examining the ideal of the one who has achieved equanimity in the next chapter, the goal is to achieve a state whereby pleasant and unpleasant objects are treated the same way, neither causing mental disturbance.

In Chatper 2, we saw that desire may be problematic as an 'upsetter' of order. In Buddhist thought we might characterise as problematic anything that is a disturber of calm. This, however, requires some qualification. Might not an upswelling of compassion disturb our calm, and yet still be a 'good thing'? Possibly, but the ideal manner of dealing with such an upswelling is surely to be one founded in mindfulness; where we observe and respond to our compassionate impulse without allowing it to disrupt and disturb that calm we have managed to establish. A more serious challenge to this idea emerges from the notion of samvega - which I have heard described as a 'sense of urgency-for-liberation'. The PED gives samvega as:

Agitation, fear, anxiety; thrill, religious emotion (caused by contemplation of the miseries of this world). ${ }^{74}$

Walshe renders the term, at D.II.214, when describing one affected by it as 'being moved to a sense of urgency by what should move one' ${ }^{75}$ This is intriguing; can one be calm and urgent at the same time? Perhaps it is possible; if we see an urgent danger (maybe a chip-pan has caught fire on our stove), we can either panic or respond quickly - but by retaining a level of calm we can actually be more rather than less effective (we calmly place a wet tea-towel on the pan, rather 
than screaming and trying to throw the pan into the sink). While challenging, I do not think the clear importance of samvega need overly problematise the view that Buddhism seeks to cultivate 'inner' calm as one of its core values.

Returning to desire as a challenge to this calm, what similarities can be found between the Brahmanic concern with order and the Buddhist focus on calm? Both are endangered by desire. For Hinduism the danger is usually in the form of kāma, whereas, as is emerging here, many types of desire threaten calm. ${ }^{76}$ I shall pick up this theme of calm later as we may find it a helpful tool in finally establishing the aforementioned typology of desire that I am investigating to see if it can be found in these Buddhist texts.

Returning then to dosa, this inverse of $r \bar{g} g a$, we find that the PED gives its meaning as 'anger, ill-will, evil intention, wickedness, corruption, malice, hatred' ${ }^{77}$ The term also has an alternative, but surely related, meaning as 'corruption, blemish, fault, bad condition, defect'. ${ }^{78}$ The PED also refers us to the Sanskrit term dvesa, and which SED defines as: 'hatred, dislike, repugnance, enmity to'. ${ }^{79}$

Dosa is useful here, as it shows us that the flip side of desire is made of the same material, as it were. The descriptions of dosa that I give above demonstrate that rāga and dosa might be seen as the opposite poles of a magnet. One attracts, one repels, but both are made of the same material and the underlying principle of action derives from the same processes. If we see rāga and dosa as representing opposite ends of a spectrum of partiality to an object, we can presume a central point that represents the equanimity ${ }^{80}$ that Buddhism aspires to develop.

\section{Moha}

Moha - the third of these unskilful roots - is associated not with desire or its inverse, but with delusion or ignorance. ${ }^{81}$ In Chapter 4, assess the extent to which desire and ignorance work in tandem as factors which tie us to the world of dukkha.

\section{Lobha}

Lobha is, as noted above, most well known in the triad of lobha, dosa and moha, and in the Abhidhamma it has come to oust rāga's position in this formula. ${ }^{82}$ Lobha is commonly translated from the Pali as 'greed', but in the Sanskrit we see it ever so slightly differently. In the SED we find it as:

perplexity, confusion; impatience, eager desire or longing after... covetousness, cupidity, avarice. ${ }^{83}$

Here there seems slightly less of a judgmental tone than in the PED where it is given as 'covetousness, greed'. ${ }^{84}$ In the Pali, we do not have the relatively neutral senses that we find attributed to lobha in the Sanskrit. C. L. A. De Silva describes it as 'a state associated with consciousness which causes attachment to an object' ${ }^{85}$ 
We can presume that as one of the three unskilful roots (akusalamūla), lobha is a negative form of desire - but just how does the Abhidhamma understand lobha? In the Vibhariga ${ }^{86}$ we find a discussion of lobha, dosa and moha as the tīni akusalamūtāni - the three unskilful roots, or the three root-causes of unskilful action. At Vibh. 361 we find a list of terms which are examples of lobha. These seem to be occurrences of desire - instances of lobha - which are to be viewed universally, or at least very often, as akusala. Looking at this list of what is encompassed in the notion of lobha will lead to the consideration of a number of the terms in the list. I do not go through and deal with every single term listed, but rather with those that are either interesting or particularly evocative. At Vibh. 361, then, we read:

What then are the three unskilful roots? Greed, Ill-will and Delusion. What then is greed? ${ }^{87}$

In typical Abhidhamma style, we get not a discussion, but - as noted above a list. In giving this list, I put in brackets Pali terms that I shall discuss shortly. Some minor terms are addressed within footnotes, to give a sense of the range of ways in which lobha is understood:

It is passion, infatuation, ${ }^{88}$ seduction, compliance, rejoicing in, rejoicing in passion, infatuation of consciousness, wanting (icchā), yearning, clinging, greed, ${ }^{89}$ excessive greed, attachment, impurity, ${ }^{90}$ distraction, deceit, production, seeking of production, ${ }^{91}$ seamstress, ${ }^{92}$ ensnarer, river, clinging, ${ }^{93}$ a spreading river, pursuit, connected with resolve (panidhi), guide to renewed existence, jungle, undergrowth, ${ }^{94}$ intimacy, (sticky) affection, ${ }^{95}$ regard (apekkha) , a relative, wish $(\bar{a} s \bar{a})$, wishing, state of wishing, wishing for visible objects, wishing for audible objects, wishing for odorous objects, wishing for flavoursome objects, wishing for tangible objects, wishing for gains, wishing for wealth, wishing for sons, wishing for life, desire, ${ }^{96}$ excessive desire, act of desiring, state of desiring, covetousness, being covetous, state of being covetous, agitation, ${ }^{97}$ desire for piety, ${ }^{98}$ wrong passion, ${ }^{99}$ lawless greed, longing after, ${ }^{100}$ state of longing after, aspiration, envying, imploring, sensual craving, craving for being, craving for non-being, craving for form, craving for the formless, craving for cessation, craving for audible objects, craving for visible objects, craving for odorous objects, craving for flavoursome objects, craving for tangible objects, craving for ideas, ${ }^{101}$ flood, bond, tie, attachment (upādānam ), obstruction, obstacle, covering, binding, depravity, latent disposition, possession, creeper, avarice, root of suffering, source of suffering, origin of suffering, Māra's snare, Māra'a fish-hook, Māra's, Māra's sphere, river of craving, net of craving, leash of craving, ocean of craving, covetousness (abhijjhā), the unskilful root of greed - This is called greed. ${ }^{102}$ 


\section{Terms from the lobha list at Vibhanga 361-2}

I want to now comment on some of the terms found in this passage, before moving on to look at some that are notably absent from it. I address the terms in the order they appear in the passage above, but first want to note that I shall leave tanha until last. I wish to examine this term in some detail due to its centrality to much Buddhist doctrinal thought.

\section{Icchā}

So we come to icchā: 'wish, longing, desire'. ${ }^{103}$ Despite the neutral tones of this PED definition, icchā is commonly used to describe desire in a negative light. In the Tanhā Vagga of the Dhammapada, we find the last section deals not with tanhāa, but with icchā:

Weeds are the bane of fields, wishing is the bane of humanity, Hence what is given to the wish-departed ${ }^{104}$ is a great fruit. ${ }^{105}$

It is worth noting that 'craving' here is not the only 'bane' of humanity, as the preceding sections also give the same treatment - virtually identically - to moha, dosa and $r \bar{a} g a$. Here $i c c h \bar{a}$ is associated with the three fires, those central flaws in the nature of us puthujjanas, us mere worldlings.

The term icchā is also addressed in the Iccha Sutta in the Samyutta Nikāya. When the Buddha responds to a question from a deva:
'With what is the world bound? With the destruction of what is it unbound? ${ }^{106}$
With what's abandoning are all bonds cut free?'
Wanting is that which binds the world, with the destruction of wanting is it unbound;
With the abandoning of wanting, all bonds are cut free. ${ }^{107}$

Here once more, yet another form of desire is contrasted with liberation. As with many forms of desire, we see the ending of desire as equivalent to the attainment of liberation.

Looking at the above verse we might be tempted to see it in more cosmological terms than psychological ones. Might this be a form of cosmic desire, akin to or analogous to that found in the previous chapter? I do not think so. The loka, (world) being referred to here, I take as meaning the world-as-we-experience-it. Peter Harvey argues, at some length, in The Selfless Mind, that loka is to be interpreted in this way. One type of evidence he advances for this position is linguistic:

The linguistic derivation of the word 'loka' also indicates it as meaning 'experienced world'. Related words in Pāli are 'oloketi', 'he looks at', 
and 'àloka', 'light'. Related Sanskrit words are locate, he perceives, and locana, 'eye' (PED.586f). Thus the primary meaning of loka is 'visible (or perceived) world'. In general usage, loka is always linked to beings in some way, thus the Buddha says 'I quarrel not with the world (lokena), ${ }^{108}$ the world quarrels with me' (S.III.138), and it is said 'Indeed the world has fallen on trouble; one is born and grows old and dies...' (D.II.30). ${ }^{109}$

In this sense we can think of the world as a construction which emerges out of an interaction and encounter between external empirical reality and the activity of consciousness. In this sense, the world is built by desire.

We can see this in numerous ways - from the fact of our birth as a result of desire, to the manner in which desire colours all of our experience of reality, and, through its effect on perception, our view of the world. It is indeed the builder of worlds in this sense; we inhabit the kāma-loka - the world that desire built. I do not think that we need to make desire metaphysical to make it a builder of loka. The relation of mind and mental phenomena to the outside world is discussed at more length in Chapter 4.

\section{Paṇidhi}

Now a term whose negation is clearly not equivalent with spiritual attainment despite its inclusion in this list - panidhi. ${ }^{110}$ We might not even consider the term one for desire at all, but it does seem to represent a form of motivational preference towards certain objects, as well as being found in this list of terms associated with lobha. The PED gives it as 'aspiration, request, prayer, ${ }^{111}$ resolve'. ${ }^{112}$ But in usage it can be a little awkward to translate as this. In the Dasuttara sutta, we see panidhi in use in a compound, as Săriputta is giving a lesson to the bhikkhus:

What four things are very helpful? Four Wheels ${ }^{113}$ - a suitable dwelling place, association with good people, perfect resolve of the self, ${ }^{114}$ and formerly made merit. These four things are very helpful. ${ }^{115}$

Here we have panidhi as a form of resolve, or a mind state that can be part of spiritual development. Clearly it is not explicitly associated with 'desire' as such, but it does seem of a similar type. Furthermore, it seems similar in some senses to the important term padhāna, which will be examined shortly.

\section{Paṇihita}

A related term is panihita, which initially seems fairly close to panidhi in meaning, given as 'applied, directed, intent, bent on, well directed and controlled'. ${ }^{116}$ While both represent mental states focussed on the future, panihita seems more concerned with focussed and controlled attention. While this may seem fairly neutral in a moral sense, or even in terms of spiritual efficacy, it is interesting to 
discover that the negation of panihita, that is appanihita, is often linked closely with nibbāna. ${ }^{117} \mathrm{~A}$ note in $\mathrm{CDB}$, commenting on the use of appanihita at S.IV.295, where one 'emerging from the cessation of perception and feeling' 118 has three kinds of contact which first resume - emptiness contact, signless contact (animitta - see page 95), and undirected (appanihita) contact. These relate to the vision of nibbāna attained at this stage, and the note explains how these three relate to nibbāna:

Nibbāna is called emptiness because it is empty of lust, etc.; signless, because the signs of lust, etc., are absent; and undirected, because it is not directed towards lust, hatred or delusion. ${ }^{119}$

Here the concern is primarily in relation to specific objects - negative ones. But the idea of undirected thought is a powerful one, and we can see why it is associated with nibbāna. The same three terms used in relation to 'contact' above also recur in Mil. 337, as the three components of the 'Blessed one's jewel of meditation': ${ }^{120}$ empty, signless and undirected meditation. ${ }^{121}$ These three kinds of meditation are often seen in post-Canonical literature as three ways of coming to access nibbāna - as, in Vism. ${ }^{122}$ - the three gateways to liberation.

Primarily through an understanding, then, of its negation, we may come to see that panihita is a kind of object-directed attention that may serve us well along the path, but which we must ultimately leave behind. However, all three types of gateway-meditation seen here should not lead us to vilify their opposite. Most samatha meditation is not-empty (it has an object), it has a sign, and is, if to be done properly, well-directed and focussed. Indeed, we see, at A.I.8, two types of panihita, wrong-directed thought and right-directed thought (micchäpanihita and sammā panihita respectively), and are told of the beneficial effects of sammā panihita. These include the 'breaking down of ignorance, and the arising of understanding,. ${ }^{123}$

This fits with much we shall see in the next chapter regarding ditthi - views, as they too can be right or wrong - but ultimately we must pass beyond either to attain the highest goal.

\section{Padhāna}

At this stage I shall look at the more common term, related to the two above: padhāna. We have seen that one of the most central elements in this study is the extent to which positive forms of desiring are described and discussed within the Canonical texts. Surely central to this is an analysis of the approach to the efforts made by monks and nuns (and by extension also lay Buddhists) in their spiritual endeavours. The mental states which such endeavours necessitate are not purely negative - not an attempt to achieve a mental nothingness - but rather are positive proactive undertakings. Padhāna is central to this. The PED gives padhāna as 'exertion, energetic effort, striving, concentration of mind'. ${ }^{124}$ 
Padhāna is, then, seen as a necessary activity for the Buddhist practitioner. In the Sangiti Sutta, as at many other points, we find that padhāna is described as being fourfold:

Four Strivings. ${ }^{125}$ Striving for restraint, striving for abandonment, striving for development, striving for guarding. ${ }^{126}$

While 'striving' does not necessarily have to be viewed as a form of desire, its status as something positive and recommended is worth noting. It represents a form of mental intentionality which, when appropriately directed, is clearly kusala.

In looking at padhāna, we are drawn to a term which is often translated in a similar manner - vāyāma. This term for 'striving, effort, exertion, endeavour' 127 is most notable for its place in the Noble Eightfold Path. As the seventh Pathfactor, sammā-vāyama - right effort - is important and interesting.

It is important because it represents a proactive mental state at the heart of Buddhist practice. This we have seen in padhāna, but sammā-vāyāma is so central that it is worth looking at further. The practice of sammā-vāyama is seen to involve the use or exercise of padhāna. We can see this in the description of sammā-vāyāma in the Mahāsatipațhāna Sutta:

And what, monks, is Right Effort? Here, monks, a monk rouses his will, makes an effort, stirs up energy, exerts his mind and strives to prevent the arising of unarisen evil unwholesome mental states. ${ }^{128}$

We can see a number of interesting things here. In this exertion, we see not only padhāna (as 'padahati'), but also chanda, which is above translated as 'will', and the term cittam pagganhāti. This last phrase indicates an exertion of the mind, but pagganhāti is a minor term for exertion, deriving this meaning from its primary sense of 'to stretch forth, hold out or up, take up'. ${ }^{129}$ This idea of stretching forth the mind is evocative - it seems to give the idea of a mind being turned to a specific task, accompanied with energy as an act of will. We can view chanda here as this willing, this choosing to take up the battle (as will be shortly discussed, chanda is sometimes described as 'desire-to-do').

This approach, the exertion of mental resources in this spiritual task, seems to be based on the prior existence of sammā-sankappa. Once we have resolved to undertake the task, only then are we going to engage with the task itself. We shall see in the Chapter 4 how sammā-sankappa is viewed as itself deriving from sammā-ditthi, right-view.

Here though, there seems to be an active fight against negative mental states, against akusala dhammas, which we might take on one level as a fight against desire. At the same time, it represents the expression of the will - and by extension is surely the expression of a competing desire. Here desires do battle, what we might describe as a higher-order desire seeking to defeat lower-order desires for a kusala purpose. ${ }^{130}$ 
While we can extrapolate this position, it is worth remembering that there is no Path-factor called sammā-chanda, ${ }^{131}$ or sammā-kāma. We might wish to view this as indicating that the effort, the exertion referred to here, derives from desires of a different type to those it seeks to combat. We saw above that we may see this as sammā-saikappa, but what is it that incites us to make or form this resolve? We could see it as negative, that sammā-sarkappa is based on a turning away from certain aspects of the world, away from the world of craving and loss. While this strategy is present in some aspects of Buddhist thought, ${ }^{132}$ even this can be seen as a form of desire - albeit inverted.

Furthermore, to limit Buddhist aspirational thought to the negative seems to misrepresent what we find in the suttas, as well as portraying an absence of positive, higher-order goods in Buddhist thought. These higher-order goods are present. One at least is vital - nibbāna. ${ }^{133}$ This is the highest good, and represents a positive goal. Some might suggest that nibbāna is itself negative, and it is often described primarily in terms of what it is not. This should not be taken, however, as indicating that it is a purely negative goal. Two reasons can be invoked for this at this point.

First, in terms of description, we can say what 'nibbāna is not'. The non-nibbānic is part of the world of our lived experience (and therefore language). This is not, however, to say that there are not positive aspects to nibbanna - just that these lie beyond this realm of being, and therefore beyond the linguistic conventions of it.

Second, to view nibbāna as nothingness is to move away from the soteriological middle-way that it represents. To see nibbāna as negative only indicates it is a form of annihilation - an ending of all. It is the ending of much, but despite the lack of consensus in Buddhist studies about the nature of nibbāna, few would argue that it is to be seen as obliteration.

We may also recognise other higher-order goods in Buddhism, which while lower than nibbāna, are still not negative. Mettā, for example, might be defined as the absence of ill-will, but this does not prevent it from having an active and positive content. It is not just a 'nay-saying' to ill-will, but rather a benign mentalstate, whose arising we should strive for alongside (or more accurately, perhaps, intertwined with) the eradication of malign mental states.

\section{Apekkhā}

The next term from the lobha list is apekkha.$^{134}$ This term is less obviously negative than many, being along the lines of: 'attention, regard, affection for; desire, longing for'. ${ }^{135}$ This is interesting, as we see a hint of how desire relates to 'attention'. In thinking about how desire arises in the process of perception, it is for those items that we train our perception or attention upon that we can develop desire. However, apekkha is found to be implicated as a desire to be abandoned:

That of wood, iron or fibres is not a strong bond, say the wise, A stronger attachment is longing for jewels, sons and wives, 
That is a strong bond, difficult to loosen, down-dragging and supple say the wise,

That too is abandoned by those who go forth, abandoning sense-pleasures they are without longing. ${ }^{136}$

Here we see the absence or negation of apekkhā as equivalent with the abandonment of kämasukha - sense pleasure. So, here we see another type of longing or desire contrasted explicitly with spiritual development. However, apekkha $\bar{a}$ is interesting in that its negation is not always to be seen as wholly positive. The PED gives anapekkhā as 'without consideration, regardless, indifferent' ${ }^{137}$ I have used 'indifferent' above, as it seems to fit the context, but there is a sense in which an anapekkha can be seen as being thoughtless. Indeed, the past-participle of the related term apekkhati, apekkhita, is given as 'taken care of, looked after, considered'. 138

From this we can perhaps come to the position that apekkhā is the turning of one's mind to something - it is caring about an object. This may be negative, or indeed ethically positive. The key is, I feel, a mix of what we turn our attention to, and how we regard the object of attention. The term is, therefore, interesting as within its range of uses we see a range of the understandings of how an individual can relate to objects of perception and attention.

\section{$\bar{A} \mathbf{s a ̄}$}

In $\bar{a} s \bar{a}$ we have a term of quite general usage, covering such things as 'expectation, hope, wish, longing, desire', ${ }^{139}$ and we can here see a term used in non-negative senses, as in the Janavasabha Sutta. Here the benign yakkha ${ }^{140}$ named Janavasabha tells the Buddha of his religious intentions:

Indeed Lord, for a long time I have recognised myself free from states of suffering, ${ }^{141}$ and now the desire is established in me to be a oncereturner. $^{142}$

A noble sentiment indeed. Here, finally, we find a form of desire expressed as a positive state of mind. This is important as it illustrates the existence of non-harmful desires. While this desire is treated in a fairly conventional manner here - as something the yakkha wishes to achieve - it seems important because of its object (spiritual progress). There is nothing obviously distinctive about the type of desiring involved. ADP gives $\bar{a} s \bar{a}$ as 'wish, hope, expectation', ${ }^{143}$ and this seems even closer to its usage. It is more a sense of preference for the future than the active desiring that lead to acts of will, such as that of tanha $\bar{a}$. In the context of Janavasabha's use of the term above, we may well see $\bar{a} s \bar{a}$ as close in meaning to 'aspiration'.

We can presume, then, that $\bar{a} s \bar{a}$ is not always equivalent to desire-states such as lobha and rāga. Conventionally we might also say that $\bar{a} s \bar{a}$ here is clearly not 
identical with a tanh $\bar{a}$ type desire, but as we shall see later in this chapter, some see $\tanh \bar{a}$ as less inherently negative than is usually thought.

\section{Upādāna}

Upādāna is an important term, being one of the nidānas of the paticcasamuppāda formula. Its role in this sense is examined again in Chapter 4, but I will say something about it here.

It is important not only because it directly follows tanh $\bar{a}$ in the paticcasamuppāda process, but also in itself as it can be seen to be close to the notion of desire in some senses. The term is often translated as 'clinging', 'grasping' or 'attachment', but as we can see from the PED, this is a figurative use based on its more literal meaning. Its literal sense is given as:

(lit. that (material) substratum by which an active process is kept alive or going), fuel, supply, provision. ${ }^{144}$

This sense has largely, in Buddhist usage, ${ }^{145}$ been supplanted by a secondary meaning - albeit one that seems to draw on this primary notion. This secondary meaning, 'grasping, holding on, grip, attachment' ${ }^{146}$ is the way it is used with respect to its role in Buddhist thought, especially paticca-samuppāda.

We can see upādāna as resulting from tanhha, as 'attachment'. If we see tanhha as reaching for, or craving after, an object, we can see upādāna as a holding on (in a mental sense) to an object - as 'grasping' we can see it as a refusal to let go of objects of the mind or body. As such, upādana is to be viewed as something negative - an akusala mental state. The different types of upādana that are enumerated in the Pali texts are examined in Chapter 4 as part of the examination of desire and paticca-samuppāda.

\section{Abhijjhā}

If we look at abhijjha , another term for a variety of desire, we see that the PED gives it as 'covetousness', ${ }^{147}$ but notes that it is 'in meaning almost identical with lobha' ${ }^{148}$ But to 'covet' is an interesting notion. To 'covet' something is to wish to possess it, it is:

to wish, long, or crave for (something, esp. the property of another person). [C13: from Old French coveitier, from coveitié eager desire, ultimately from Latin cupiditās CUPIDITY] ${ }^{149}$

This sense of desiring that which belongs to another is clearly expounded in the Sevitabbāsevitabba Sutta, in the lists of things to be cultivated and not cultivated:

Here someone is covetous; he covets the wealth and property of others thus: 'Oh, may what belongs to another be mine!' 150 
We can see abhijjā in a more general role in the Sämaññaphala sutta, although here 'desire' seems a less clumsy translation, only because there is no sense in the context below of the object of the coveting necessarily being the property of another:

Abandoning worldly desires, he dwells with consciousness without desire, his mind is purified from desire. ${ }^{151}$

So, one of the 'fruits of the homeless life' (as Sämañnaphala is often translated) ${ }^{152}$ is a mind free from worldly desires. Indeed, by the end of the passage, free from all desires. This echoes the Upanisadic material where the end of worldly desires was equated with the end of all desires - although as we saw, this often was taken to mean that worldly desires had been supplanted by the desire for God or the Self.

In this passage I do not think there is any great significance to the omission of loka from the second half of the formula - in the passage, abandoning worldly desires $(a b h i j j h \bar{a})$ leads to the purification of the mind from abhijjh $\bar{a}$ in general, but might there be non-worldly desires that the samana ought to nurture rather than remove?

\section{Terms not in the lobha list at Vibhanga 361-2}

The terms addressed here are done so in the context of themes which represent key aspects of desire, as discussed this far. I begin with two of the most common terms.

\section{Kāma and chanda: common terms for desire}

\section{Chanda}

Chanda is a very common term for desire in Pali. It is often found in use in compounds with some of the other terms for desire that I have been looking at in this chapter. Unlike many of these terms, chanda is relatively neutral with regard to its ethical/kusala status. The PED gives its basic meaning as 'impulse, excitement; intention, resolution, will; desire for, wish for, delight in' ${ }^{153}$ It is used in relation to both positive and negative descriptions of desiring. After offering as a translation of chanda, the terms 'zeal, desire or wish-to-do', ${ }^{154}$ Nina van Gorkom reinforces the idea that chanda in not inherently akusala:

When we hear the word 'desire', we may think that chanda is the same as lobha. However, chanda can be kusala, akusala, vipāka ${ }^{155}$ or kiriya. ${ }^{156}$

We have, then, a term here that seems to bridge some of the key ideas that have been discussed in this chapter. By containing both notions of 'intention' and 
'resolution' and 'desire' and 'will', we might see chanda both as quite a general term for desire, and as possibly 'desire-to-do'. C. L. A. De Silva gives it just this meaning:

Conation, desire-to-do (chandō) is a state existing in consciousness which makes consciousness desire to take an object. It is not greed, but only a desire to do. ${ }^{157}$

This may prove a useful idea, as this is something that may, in some instances, prove to be different from the idea of 'desire-to-have' that I associated with käma-tanh $\bar{a}$ above. ${ }^{158}$ While chanda may at times coincide with kamma-tanh $\bar{a}$, the possibility of a non-possession-seeking form of desire has significantly more kusala-potential. Maybe we can view it such that chanda-type desires can sometimes be found much further along the kusala side of the kusala-akusala spectrum that I have been discussing.

Part of what I wish to unravel with regard to chanda is whether the distinction between positive and negative, kusala and akusala, types of chanda is purely on the basis of their objects or not. If we look to the equivalent Sanskrit term we find that the adjectival use of chanda has a range of meanings, the primary being given as 'pleasing, alluring, inviting'. ${ }^{159}$ That is, chanda represents that which has the features of inviting desire. If we move on through the SED definition, we soon find that chanda is used in a way similar to as in Pali 'pleasure, delight, appetite, liking, predilection, desire, will' ${ }^{160}$ The related term chandas is also similarly defined as 'desire, longing for, will'. 161

What is notable about chanda is its occasional explicit usage to refer to beneficial or kusala categories of desiring. We can see this in its use as part of the notion of a dhamma-chanda. We find this used as a compound term in the Sañ̃̃anātta sutta at S.II.144, but here Dhamma is being used in the sense of mental phenomena, rather than as 'teaching of the Buddha'. ${ }^{162}$ The combination of dhamma and chanda is mainly located in commentarial texts, but we also find it in the Abhidhamma in the Vibhañga analysis of sammā-padhāna - right striving or exertion. ${ }^{163}$

In this analysis, a bhikkhu is exhorted to do four things as part of this striving. These four are: chandam janeti vāyamati vīriyam ārabhati cittam paggaṇhāti ${ }^{164}$ to bring forth the desire, ${ }^{165}$ to strive/make effort, to arouse energy, to exert the mind. This should be done for the prevention of akusala states, and the production of kusala states. We see here chanda as a key aspect of right-striving. When we come, a few lines later, to the discussion of the nature of chanda in this context, we can see this positive sense of it clearly explained:

What, then, is desire? That which is desire, the act of desiring, desire to act skilfully, ${ }^{166}$ desire for Dhamma, this is called desire. ${ }^{167}$

Here I have translated chanda (and kàma) as desire, but this needs some qualification. This is desire in the explicit context of sammā-padhāna. As such we 
can see here how desire of a certain sort is to be actively produced, cultivated, if done so in a kusala manner, and aimed at a kusala object (Dhamma). In some ways the Vibhanga view here seems an extrapolation from the suttas. We do find the same factors at play in the discussions of the place of chanda within the iddhipādas.

The notion of a kusala form of chanda is reinforced by the presence of chanda as one of the iddhipādas - the 'four bases of power'. ${ }^{168}$ These four mental factors, when appropriately accompanied by acts of will can lead not only to general spiritual progress, but also to the practitioner's possession of psychic powers such as the ability to become invisible, to fly, and the like. ${ }^{169}$ The iddhipādas are described in numerous locations in Canonical texts, such as the Janavasabha sutta, at D.II.213, where Brahmā is addressing other devas:

Here a bhikkhu develops the basis of success that is furnished both with concentration gained by means of desire to act, and with forces of endeavour; he develops the basis of success that is furnished both with concentration gained by means of strength, and with forces of endeavour; he develops the basis of success that is furnished both with concentration gained by means of mind, and with forces of endeavour; he develops the basis of success that is furnished both with concentration gained by means of investigation, and with forces of endeavour. ${ }^{170}$

Throughout his discussion of chanda and the iddhi-pādas, Rupert Gethin routinely translates it as 'desire to act', ${ }^{171}$ and we can see chanda here very much as 'desire-to-do', placed as it is in a setting with concentration and striving. It is the "wish" 172 to make spiritual progress that is effective in combination with these other factors.

This represents a clearly kusala form of chanda, and seems to be much better suited to play the role of a form of desire for good objects in a kusala way that Morrison seems to wish tanh $\bar{a}$ to play. Lama Anagarika Govinda reinforces both the distinction between kusala and akusala forms of chanda, and its relation to doing, while linking its arising as kusala or akusala as related to our level of insight:

According to the level of knowledge or insight, chanda either turns into kāmacchanda (a synonym of tạhā), sensuous desire, or into dhammacchanda, the desire or rather striving for liberation. On the sensuous plane chanda mainly results in action, on the spiritual plane, as in the case of meditation it results in the progressive movement towards the aim. In both cases it is the will to realize the result of our mental activities. The protean nature of chanda is very similar to that of the word 'desire'. ${ }^{173}$

This gives a sense of chanda as potentially a force of positive spiritual charge which moves us away from tanh $\bar{a}$-type desires, towards a leaving behind of 
'seeking to have', towards a Dhammacchanda, where the goal of Dhamma is in accordance with that ascribed to it by Stephen Batchelor when he claims that:

The primary purpose of Dharma is to reestablish a consciousness of being. ${ }^{174}$

This makes chanda a vitally important notion, and also we find that chanda is a force of some power. The Janavasabha sutta passage above also demonstrates what power desire has. If we consider the role of chanda here, it is a striking evocation of the power of desire. Like the samkalpa of the Vedic ritualist, a concentrated and forceful use of desire can lead to the possession of the great powers, the iddhis. No wonder the Buddha warns against their casual use! ${ }^{175}$ Chanda can be seen here as something with a potential that the mind can find a means to unleash - so much so as to defy the normal laws of the universe. ${ }^{176}$

However, chanda is not a term for only positive forms of desire. We also find it regularly used in negative settings. Most notably, kāmacchanda - a desire for sense-pleasures - is the first of the 'five hindrances', as at D.II.301 in the Mahāsatipațthāna Sutta. However, we also saw the first hindrance in the discussion of the hindrances in the Sämaññhala Sutta (D.I.71), given as abhijjam loke (worldly desires), and earlier in the Mahāsatipațthāna Sutta, the first hindrance is given at D.II.299, as having a sarāgam cittam (a lustful mind).

We do not have to worry too much over these variations in description of the first hindrance, for chanda appears in negative contexts outside of its usual, but apparently not universal, place as the first hindrance. For example, in the Mahānidāna Sutta, ${ }^{177}$ we find chandarāga crops up regularly in the list of nidānas involved in the process of paticca-samuppāda:

And so indeed, Ānanda, feeling conditions craving, craving conditions searching, searching conditions getting, ${ }^{178}$ getting conditions decisionmaking, ${ }^{179}$ decision making conditions attachment and desire, attachment and desire conditions attachment, ${ }^{180}$ attachment conditions possessiveness, possessiveness conditions avarice, avarice conditions guarding [of possessions]. ${ }^{181}$

This group of paticca-samuppāda nidānas clearly relates to the way we interact with possessions and the like, and we next find that a rakkha - guarding leads to arguing and fighting. But what is significant in the current context is the clearly akusala form of chanda here encountered, and that it is the type of chanda that causes the problem, not the object of the chanda.

We find the ethical indeterminacy of chanda formally established in Abhidhamma analysis. Within the Abhidhamma scheme, chanda is a mentalfactor, a cetasika. Cetasikas are classified according to both their occurrence in consciousness and their kusala status. We can find this expressed in the twelfth century work, the Abhidhammattha Sangaha, attributed to Ācariya Anuruddha. 
Chanda is classified as an añ̃asamānacetasika - that is, an ethically variable ${ }^{182}$ mental factor. However, unlike cetasikas considered as sabba-cittasādhāraṇa (as universal, ever-present components of consciousness), chanda is considered to be one of the pakinnaka, occasional, cetasikas. At II.3 of the Abhidhammattha Sangaha we find the following passage:

Application, investigation, determination, energy, ${ }^{183}$ zest, and desire, these six mental factors are named occasionals. Thus, these thirteen ${ }^{184}$ mental factors are to be known as the ethically variable. ${ }^{185}$

One way, and I think one that fits with the Abhidhamma view, is that these cetasikas can be seen to intensify any state - good or bad. In their commentary on the Abhidhammattha Sarigaha, Bhikkhu Bodhi and U Rewata Dhamma explain the nature of such cetasikas:

The occasionals (pakinnaka): The six cetasikas in this group are similar to the universals ${ }^{186}$ in being ethically variable factors, which take on the moral quality of the citta as determined by other concomitants. They differ from the universals in that they are found only in particular types of consciousness, not in all. ${ }^{187}$

This is both useful and intriguing. Useful as it clarifies the status of chanda. Although the Abhidhammattha Sangaha is clearly much later than the Canonical texts on which it draws and seeks to clarify, this analysis seems in keeping with what is found within them with regard to the use and status of chanda.

The analysis of Dhamma and Bodhi is intriguing in that they say relatively little about what actually determines the ethical status of a particular instance of a chanda cetasika. 'Other concomitants' is vague, but one can only presume that the overall citta (mind-state) that the chanda cetasika is present in has its ethical or kusala status determined by the other cetasikas present. This demonstrates the existence of a kusala-variable form of desire, but more than that, the kusala status of the citta is not necessarily determined by the object of the citta, but by other cetasikas present. Nina van Gorkom reinforces this point:

Chanda is conditioned by the citta and other cetasikas it accompanies. Chanda is sankhāra dhamma, conditioned dhamma. Different kinds of chanda arise due to different conditions. ${ }^{188}$

Chanda seems an appropriate topic to conclude this examination of Buddhist terms for desire with. It can be seen to contain elements of both what is meant, in English, by 'desire' and 'will', and maybe at times even 'wish'. It is something which can be, not only on the basis of its object, ethically, or kusala-akusala, variable, and therefore can be seen as emblematic of a Buddhist belief in the possibility of the transformation of desire. 
Are we to tame or kill the beast of desire? For the Buddhist, some beasts (such as $\tanh \bar{a}$ ) can be ridden only a little way, but some (such as chanda) can be tamed and ridden almost to our final destination - although the crossing of the final threshold seems to be something we may have to do on foot, leaving our transport (be it a tamed form of desire or - to bring in a more typically Buddhist image a raft) at the door. Beyond this door, even Arahats and the Buddha may have chanda at times, for they may be motivated, conditioned by compassion for the suffering of their fellow beings, to teach others. ${ }^{189}$

\section{Kāma}

Of all the terms not in the list given at Vibh. 361, the most notable absence except in compounds - is kāma. So common a word in the suttas, it is - as often a somewhat vague or imprecise term - much more rare in the abhidhamma. In the lobha list we saw kāma used only as an object of desire (such as in kāmatanhāa), rather than as a form of desire itself, a role we saw it in often in Chapter 2.

Käma as a Sanskrit term is, as we have seen, used for both desires and their objects. It is, in Sanskrit, something of a catch-all word for desire. That it takes up two full pages of the Monier-Williams Sanskrit-English dictionary ${ }^{190}$ gives some indication of the wide range of compound words it is used in. It is primarily defined here, though, as:

wish, desire, longing...love, affection, object of desire or of love... pleasure, enjoyment; love, especially sexual love or sensuality. ${ }^{191}$

Here we can see what a range of uses käma has - and have seen its range also in the previous chapter. If we look to the Pali usage of the term we can see that it is still a term for desire, but the PED limits its basic definitions a little more, describing kāma as:

Pleasantness, pleasure-giving, an object of sensual enjoyment... sense-desire. ${ }^{192}$

The PED is interesting here, as it goes on to demonstrate the negative associations that kāma has acquired in its use in Pali texts. Kāma - as desire, rather than object of desire - becomes here a central obstacle to the religious life:

In all enumerations of obstacles to perfection, or of general divisions and definitions of mental conditions, kāma occupies the leading position. It is the first of the five obstacles (nīvaranāni), the three esanās (longings), the four upādānas (attachments), the four oghas (floods of worldly turbulence), the four āsavas (intoxicants of mind), the three tanhās, the four yogas; and kāma stands first on the list of the six factors of existence: kāmā, vedanā, saññā, āsavā, kamma, dukkha. ${ }^{193}$ 
Kāma is clearly seen, in a wide variety of contexts, as deeply problematic. This can be seen in the Aneñjasappāya Sutta, where the Buddha warns at length of the dangers of sense-pleasures:

The Blessed One said this: 'Sensual pleasures, ${ }^{194}$ Bhikkhus, are impermanent, they are empty, false and of a deceitful nature.' 195

This usage is common throughout the Canonical texts. We can however find kāma used in a more neutral, if not positive, sense. For example there is the compound sotukāma-desire to hear. ${ }^{196}$ This is a term without the negative moral connotations normally ascribed to kāma.

$K \bar{a} m a$, as mentioned above, refers to both the desire and its object. This leads to a distinction in some texts. At the opening of the Mahäniddesa we found this distinction given and elaborated upon. The two types are given as 'vatthukāmā ca kilesakāmā $c a^{197}$ - desire as object, and the defilement of desire. In most settings that I am here concerned with, it is kilesakama that is being discussed.

Furthermore there is a phrase we find throughout the commentaries and subcommentaries - and, as I shall look at shortly, in the Visuddhimagga - but which is found at only one point in the Canonical texts themselves. This is muñcitukamyata $\bar{a}^{198}$ - which is perhaps best translated as 'desire for freedom' or 'desire for liberation'. The discussion of muñcitukamyatā at Vism. 651-2 is in the context of developing knowledge of the desire for liberation, and it is the knowledge that seems under scrutiny, rather than the idea of a desire for liberation. Here there is no sense that the desire involved in desiring liberation is in any way problematic or contradictory at all.

The desire for liberation is described in a vivid image at Vism. 665. Here we are told the tale of a man who discovers that the woman he lives with is a 'ghoul'. ${ }^{199} \mathrm{He}$ has followed her at night, and discovered her feasting on the flesh of the dead in the graveyard. He is, understandably, scared, and runs quickly to a safe, quiet place and hides there. How does desire for deliverance fit into this grim scenario? Buddhaghosa explains:

Herein, taking the aggregates as 'I' and 'mine' is like the man's living with the ghoul. Recognising the aggregates as impermanent, etc., by seeing the three characteristics is like the man's recognizing that she was a ghoul on seeing her eating human flesh in the place for the dead. Appearance as terror is like the time when the man was frightened. Desire for deliverance is like his desire to escape. ${ }^{200}$

He goes on to liken his quick escape to 'the Path', but we can see fairly clearly here how he uses the notion of muñcitukamyatā. He sees it as a sensible response to the unpleasantness of samsāra. All of Buddhaghosa's references to muñcitukamyatā seem based on the treatment in its single, known Canonical appearance at Pațisambhidāmagga I.60-2. Here the concern is with the knowledge of desire for 'deliverance', and is concerned with the development of equanimity with regard to 
formations (saikkhäras). Here, the desire for deliverance - or our knowledge thereof - is developed to develop the virtue of equanimity. This gives this sense of desire a tone which seems far from the craving of tanh $\bar{a}$. If it is something which contributes to equanimity, it will surely lack the desperate tone of much desiring, being something altogether calmer, more reflective and positive. The implications of this notion of desire will be discussed later.

\section{Desire and disturbance: paritassanā}

A word not found in the list discussed earlier, but which reminds me of much discussed in Chapter 2, is paritassanā: 'trembling, fear, nervousness, worry, excitement, longing, ${ }^{201}$ While this is not directly described as desire, it is in the sense of 'longing' that I am particularly interested in it.

Many religions make much of notions of yearning - albeit usually within devotional theistic traditions. Some even see 'yearning' - which I associate with 'longing' - as a core element of religious practice. Pamela Anderson goes as far to see yearning as an indispensable component of religion:

I support an account of female desire, in the form of a rational passion named 'yearning', as a vital reality of religion. ${ }^{202}$

Interestingly this conclusion is, in part, reached via an examination of certain bhakti practices. While the existence of yearning and longing in Hinduism is in no doubt, can we see a role for it in the view of religion given by the Pali Canon? And if we cannot, is this not problematic? Anderson associates yearning and longing distinctively with female forms of religious practice. A cynic might argue that Theravāda Buddhism has no room for desire, ${ }^{203}$ and that by its 'coolness' this form of Buddhism is repressive of emotionality. I would not go quite so far as this, and while 'rational passion' may be a little strong for Buddhism, 'rational desire' might well fit into some of the forms of desiring I wish to suggest exist in Buddhism.

Furthermore, Buddhism is sprinkled with a range of positive kinds of emotion. The most obvious example is probably mettā an active form of love or sympathy ${ }^{204}$ but it is not alone. Emotions have an important role in Buddhism, as Damien Keown states:

The correct role for the emotions in Buddhist ethics is to be found in the sentiments of love and concern which inspired the Buddha to make the choices he did. ${ }^{205}$

We do not have to concur with Keown's association of Buddhist ethics with Aristotelianism to assent to this claim. Emotional responses are vitally important to Buddhism, so much so that we might argue that the Buddhist project is an attempt to train the emotions, rather than suppress or eliminate them. Indeed, at least as much Buddhist practice seems aimed at nurturing positive emotions, as is aimed at removing negative ones. 
Returning to paritassana $\bar{a}$, despite what I have said about longing, it is perhaps clear already that we are likely to see its use in a primarily negative sense. Not only is it longing, but also excitement, nervousness and worry. Bodhi and Ñānamoli ${ }^{206}$ translate it as 'agitation', and I have already noted that part of the problem with desire is that it can be an enemy of calm. Clearly such an excited state as paritassanā is unlikely to be viewed as healthy. In the Cülasīhanāda Sutta the ending of paritassana $\bar{a}$ is equated with attainment of nibbāna:

When he is non-attached, he is not agitated,

When non-agitated, he personally attains nibbāna. ${ }^{207}$

This fits with what is an emerging pattern here - the ending of various desiretypes as synonymous with the attainment of nibbāna.

\section{Willing in Buddhism: adhițthāna and cetanā}

\section{Adhiț̣āna}

Before moving to the most common term for will (cetanā), if we understand 'will' as that which carries out the resolve of saikappa, I first wish to look at a term with a similar meaning - adhitthanna. This is given by the PED as 'decision, resolution, self-determination, will' ${ }^{208}$ We might, however, initially see adhitthāna as closer to sankappa than cetanā, and indeed Maurice Walshe translates adhitțāna as 'resolve'. He does so at D.III.229 when the Sangitti Sutta - in listing groups of four - gives four types of adhitthāna:

Four kinds of resolve (adhițthānāni): [to gain] (a) wisdom, (b) truth (sacca), (c) relinquishment (cāga), (d) tranquillity (upasama). ${ }^{209}$

Not only does this give us a sense of the use of adhitthanna, it also represents it in a positive light. We can occasionally find it included in a less wholesome context though. In the Alagaddūpama Sutta, we find someone being warned about paritassan $\bar{a}$, and find a list of things that the Buddha's teaching recommends we eliminate. This list is given, at least in the CSCD edition, as one long compound: dițthitțhānädhitthānapariyutțānābhinivesānusayānam. If we look closely we can see adhițthāna in there. As you can see below, some render adhițthāna as decision - making it more like cetanà than saikappa:

He hears the Tathāgata or a disciple of the Tathāgata teaching the dhamma for the elimination of all standpoints, decisions, obsessions, adherences, and underlying tendencies, for the stilling of all formations, for the relinquishing of attachments, for the destruction of craving, for dispassion, for cessation, for Nibbāna. ${ }^{210}$ 
Here we see adhitthāna as part of a chain of negative terms. It seems, then, to sit between cetanā and saikkappa in meaning, somewhere between the resolve and the willing to act.

However, this general discussion ignores the most central use of the term, where it is given a much more important role to play. We find this not so much in the nikāya-pitaka as in later literature, where adhitthāna is one of the pāramīs the perfections. In this context, we might better translate it as 'determination'. This is a useful term as it captures something of both resolve and choice. In many ways

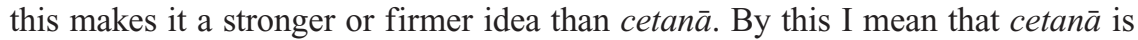
ever-present in consciousness, and may be weak or strong, but adhițthāna is often viewed as a somewhat firmer form of resolve.

\section{Cetanā}

An important term that I now wish to address, particularly in the context of the discussions both above and in Chapter 1, is cetan $\bar{a}$. The PED gives this term as: 'thinking as active thought, intention, purpose, will'. ${ }^{211}$ Now, we might be tempted to read from this that cetanā is very close in its meaning to saikappa, but cetana has a specific usage and varies significantly from saikappa. Cetanā has a more tightly defined role in the process of coming to act, and is most commonly translated as 'will' or 'volition'. Rupert Gethin recounts for us the standard role it is given in the Pali texts:

According to the Nikāya formulation, will or volition (cetanā) constitutes action (kamma); having willed one performs actions by body, speech and mind. ${ }^{212}$

We can see cetan $\bar{a}$ as that whereby we express our desires, and other mental states, by coming to act upon them. If we view it in the same way that 'will' was discussed in the introduction, then cetana can be seen as that which lies between the desire and the act. We choose what it is we wish to do, then we will do it leading to the act.

Cetan $\bar{a}$ is important because of the role it plays in the area of kamma. Although kamma is literally 'act' or 'action', in the production of kammic consequences, it is usually seen in Buddhism that the vital act in such a context is a mental one. It is by cetan $\bar{a}$ that we generate the kammic force behind our acts. Not only does this have an explanatory role in the process of kamma, but it also makes intention a key component of the Buddhist understanding of ethics and ethical consequence:

Perhaps Buddhism's most important contribution to this development of the concept of karma was to have made the crucial act a mental one, a 'volition' or 'intention' (cetan $\bar{a})$ such that it was the presence of this, rather than the external act alone, which became the first karmically significant force. ${ }^{213}$ 
Steven Collins seems to be along the right lines here when he acknowledges the centrality of cetan $\bar{a}$ to the processes of action and kamma. Another writer who recognises the importance of this notion is Damien Keown. He places cetanā in the context of choice, particularly moral choice; indeed he is not wholly happy with the rendering of it as 'volition'. Cetan $\bar{a}$, in his view, arises affected by six cetasikas (components of consciousness):

namely: 'applied thought' (vitakka), 'sustained thought' (vicāra), 'resolution' (adhimokkha), 'courage' (viriya), 'joy' (pīti) and 'desire' (chanda). ${ }^{214}$

Keown splits these six into two broad categories. The first three he describes as forms of 'deliberation', while the latter triad he classes as forming the 'impulse to act'. We can see partly now why he might not have been happy with the translation 'volition', as this role seems largely fulfilled by the viriya-pitti-chanda group, once taken collectively. This view sees the 'will' (I will use this for cetanā for now) as both emotional and rational.

Our choices (what we will) arise, then, from a holistic set of mental processes. It would seem that desire (in most of the forms examined in this chapter) is something that precedes cetan $\bar{a}$. In the model proposed by Keown this is the case - the term chanda representing the forces of desire. ${ }^{215}$

\section{Desire, resolve and the spiritual quest: sañkappa and esanā}

\section{San்kappa}

Now we can cast our thoughts back to Chapter 2, as I wish to follow up the Pali equivalent to the Sanskrit term samkalpa. In Chapter 2, we saw samkalpa as intention, as the resolve behind action, particularly ritual action. In Buddhist usage we find the term saikappa, ${ }^{216}$ which the PED gives as 'thought, intention, purpose, plan' ${ }^{217}$ Of these, clearly 'intention' is both most interesting in the current context and closest to the Vedic use in Sanskrit, although 'resolve' seems to be a good candidate as well. Another possibility which captures the sense of sankappa quite well is 'aspiration' ${ }^{218}$

Regarding the meaning of saikappa, Rupert Gethin offers a view which confirms it as 'intent', but that also links it to vitakka:

A samkalpa is literally, then, a 'conforming', a '(suitable) arrangement or adaptation'. However, the word is regularly used of a clearly formed thought or idea; it thus conveys the sense of 'intention' or 'purpose'. One might say, then, that samkappa is the gearing of mind to whatever is its object in a definite and particular way. By the time of the early Abhidhamma texts this is clearly identified with the technical term vitakka, ${ }^{219}$ The overriding connotation in this connection is that of the first jhäna-factor. Yet, as we have seen, the association of vitakka and 
samkappa is also present in the Nikāyas, though perhaps in a fashion that suggests a rather looser connection. The general idea seems to be, then, that samkappa is equivalent to the way in which the mind applies itself to or thinks of various objects. ${ }^{220}$

This explanation of sarikappa links it to something rather like willing, or an understanding of how the mind relates to objects. To see the extent to which we can view sankappa as a desire-like notion, we need to see its usage in Buddhist settings. Sankappa is most often found in the term sammā-sankappa, the second ariga (factor) of the eightfold ariya-magga. Sammā-sankappa is usually translated as 'right-thought', and is an element of the path which many books seem to treat rather quickly, doing little to distinguish it from sammā-ditthi, 'right understanding,.221 One of a number of places where this is described is in the Mahäsatipațthanna Sutta:

And what, Monks, is 'right-thought'? The thought of renunciation, ${ }^{222}$ the thought of non-ill-will, the thought of non-injury, this, Monks, is called 'right-thought'. 223

This gives a general sense of the term as something which should be used to guide our relations with both others and ourselves - a sense of how one ought to lay out intentions for actions and for thoughts - of the resolve one ought to develop. If we cannot go quite so far as to describe it as a form of desire, it certainly can be seen to represent a form of noble aspiration. In the Vibhariga we find the same description of sammā-sañkappa as in the Mahāsatipațthāna Sutta and elsewhere, but also find an Abhidhamma approach:

Now, what is 'right-thought'? That which is reasoning, reflection, ${ }^{224} \ldots$ and so on..., right-thought, path-element, included in the path, this is called 'right-thought'. ${ }^{225}$

This may seem to add little to the sutta analysis, but we see within the idea here something broad. Sankappa includes resolve and intention, but seems also to include certain types of reflection and reasoning. This makes sense, if we realise that intention or resolve is the result of reflective processes.

One element of sammā-sankappa, as seen in the passage above from the Mahäsatipațthāna Sutta, is nekkhamma-sankappa. Nekkhamma-sankappa is the resolve to achieve desirelessness. Nekkhamma is an interesting term, which the PED gives as:

Giving up the world \& leading a holy life, renunciation of, or emancipation from worldliness, freedom from lust, craving $\&$ desires, dispassionateness, self-abnegation, Nibbāna. ${ }^{226}$

This is clearly a state in accordance with Buddhist goals. It makes sense then to consider it as something to point our intentions at. The term however is interesting 
in other ways as well - throwing light on käma. Gethin offers his translation of the term:

I have translated nekkhamma as 'desirelessness' largely because in the present context it stands in opposition to kāma. But the derivation of nekkhamma has been a matter of discussion. ${ }^{227}$

Following this, he offers some discussion of its derivation, before coming to a particularly relevant conclusion:

Now, kāma in the Nikāyas is used to mean both 'desire' and 'what is desirable'; this is equally true of kamma in Sanskrit. From the Niddesa onwards this distinction is expressed in terms of 'desire as defilement' (kilesa-kāma) and 'desire as object' (vatthu-kāma). Strictly, then, that which is opposed to käma, namely nekkhamma, ought to reflect this distinction. It seems to me that this is why the commentaries seize on the possibility of taking nekkhamma as 'turning away' or 'departing': nekkhamma is absence of desire because it turns away from desire, but it also turns away from what might be desired. ${ }^{228}$

This is illuminating, and shows the relation of object and subject in the desiring process. We can see why the aspiration to remove desire from our mental profile can also often be seen as a turning, in some sense, away from the world. This is not, though, a world-weary withdrawal away from temptation. The process of 'turning away' discussed here seems more to do with the moving of attention. Further, without the inner-work, without addressing 'our' desire, the process of achieving nekkhamma regarding objects can surely never hope to succeed.

Returning, then, to Nekkhamma-sankappa, we might describe it another way: as right thought for desirelessness - but this does seem clumsy. However if we opt to consider an aspect of sammā-sankappa as 'intention to be without desire' or 'resolve for desirelessness', we may seem to be paradox-bound, headed for the 'desire to be desireless'. As hinted earlier, there are two approaches to such potential problems.

The first is to say that we need desire in order to be rid of desire, and that it is a gradual process whereby gross desires are replaced by increasingly noble desires, until we reach a point where the last few subtle and refined desires can be let go of. We might think as an example here of the desire for nibbāna having to be abandoned as a final means of attaining it.

The second approach, whose compatibility with the first will be considered later in this chapter, is to argue that in the phrase 'intention to be without desire' what is meant by an 'intention' is qualitatively distinct from what is meant by 'desire'.

If we were to limit sammā-sankappa to 'right-thought', this would limit the extent to which we could understand it involving intentionality, and may 
make it rather close to what is meant by the first path-factor, sammā-ditthi. 'Right-resolve' seems to overcome this, and takes into account the other comments above about the possible role of reflection in sammā-sarkappa, as well as seeming closer to the manner in which sammä-sarkappa operates as a path-factor.

If we see sammā-sankappa as a kusala path factor, its inverse is 'wrong resolve'-micchä-sarikappa. Again we come to concerns with the kusala status of these mental states. While the criteria of kusala-akusala has been discussed already, we can see here that right resolve is clearly kusala as it is that resolve, that determined resolution, that is a necessary but not sufficient condition of progress towards nibbāna.

Wrong resolve then, as akusala, is a hindrance to spiritual progress. But what does micchä-saìkappa consist of? Is it the desire to do wrong? The Mahācattārīsaka Sutta gives us an insight into this:

What, monks, is wrong resolve? The resolve for sensual desire, the resolve for ill-will, and the resolve for harm: this, monks, is wrong resolve. ${ }^{229}$

These factors that make up wrong resolve are all negative, and might all be traced to moha or avijja in some sense - and the second and third can also be seen to relate to dosa. What is also interesting in this sutta is that following this we are given an account of sammā-saikappa that says something noteworthy. It is said here that there are two kinds of sammā-saikappa. One form is mundane, affected by the âsavas, the taints, although still preferable to micchä-saikappa. There is also a supramundane form of sammā-saikippa, a noble form. ${ }^{230}$

This second sense of right resolve means that sammā-saikappa is not only, or at least not primarily, to be understood as the absence of kāma, byāpāda, and vihims $\bar{a}$ but as something more substantial and positive. This twofold explanation is closely related to the structure of the understanding of samma $\bar{a}$-ditthi - rightview - as we shall see in the Chapter 4 . These factors which compose the noble form of sammā-saikappa are:

The thinking, thought, intention, mental absorption, mental fixity, directing of mind, verbal formation in one whose mind is noble, whose mind is taintless, who possesses the noble path, and is developing the noble path. ${ }^{231}$

This indicates its positive nature as more than the absence of negative traits. This is an active model of sammā-saikappa.

\section{Esanā}

A term we find used in a number of places in Canonical texts, including the Sangīti sutta, is esanā. ${ }^{232}$ Given by the PED as 'desire, longing, wish', ${ }^{233}$ this term is interesting as it initially appears that we can see it applied to both wholesome 
and unwholesome objects. In the Sangiti sutta we find three types of it enumerated: 'Tisso esanā-kāmesanā, bhavesanā, brahmacariyesana,${ }^{\text {,234 }}$ These three types of esanā are for sense-pleasures ( $k \bar{a} m a$ ), becoming or being (bhava) and the holy life (brahmacariya). The first two equate to the first two types of tanh $\bar{a}$, but the third, rather than being for abhava - non-being - is for this noble end.

Walshe translates esan $\bar{a}$ as 'quest ${ }^{235}$ in this context; presumably as these three goals are things at which we, consciously or not, direct our lives towards. But does his translating it in this manner lose the sense of 'desire' found in the PED definition? To an extent it does, but what we find common in both notions is the idea of 'wish' - goal orientated action. We find the same three types of esana at S.V.44, ${ }^{236}$ in the Maggasamyutta in a sutta entitled the Esana Sutta. Here the three types of esana are given, followed by a fairly standard recounting of the Noble Eightfold Path. The purpose of the sutta is explained as developing the Path for direct knowledge of these three types of esana . $^{237}$

What is interesting is what comes next. We now see that the three forms of esana are all negative. After developing a full understanding of them, the Noble Eightfold Path leads to the utter destruction ( parikkhayaya) of the three forms of esan $\bar{a}$. Next we are told that the Path's development is for the abandoning (pahānāya) of these three searches. These are clearly not searches or goals that one should aim at - the Path is directly opposed to them, and is the means to their abandonment.

What are we to make of this? If the three objects of esanā were the same as for tanha $\bar{a}$ this would be straightforward, but what of brahmacariyesanā? Bhikkhu Bodhi informs us that Säratthappakasinī, the commentary to the Samyutta Nikāya, explains 'brahmacariyesanā as the search for a holy life consisting in a wrong-view'. ${ }^{238}$ It would seem then that brahmacariyesana refers not to the Holy life, but $a$ holy life - a path other than the Buddhist one, or maybe the Buddhist path wrongly grasped. This is one way to view brahmacariyesana $\bar{a}$, but one could view esanā in general in different ways. Sayadaw U Panna Dipa, in his book Salient Articles on Buddha Desana, makes use of esanā when making a distinction between tanh $\bar{a}$ and upādāna:

the root cause of pains of the five aggregates which one suffers for one's own desire or search is called 'esanā tanhā'. ${ }^{239}$

What is meant here is not wholly clear, but it seems to be identifying, although no textual reference is given, esan $\bar{a}$ as a type of tanh $\bar{a}$ related to the types of desires one is following - to whatever it is one is looking for. This might lead us to view brahmacariyesana $\bar{a}$ as an unskilful way of seeking in a religious context. This is an idea that would stand further investigation, although sadly there is not room here. ${ }^{240}$

Esanā is not always cast in a negative light. Indeed, we can see it used in the term pariyesan $\bar{a}^{241}$ in an obviously kusala sense in just the title of the Ariyapariyesana $\bar{a}$ Sutta. ${ }^{242}$ This sutta makes a distinction between an ignoble searching (anariy $\bar{a}$ 
pariyesan $\bar{a}$ ) and a noble search (ariya pariyesan $\bar{a}$ ). The noble search takes us to nibbāna, while the other, the anariya $\bar{a}$, is directed at other objects:

And what is the ignoble search? Here someone being himself subject to birth seeks what is also subject to birth. ${ }^{243}$

This makes fairly clear that esana is not to be viewed wholly as negative. ${ }^{244}$ The only way that a distinction seems to be made between kusala and akusala forms is, here, on the basis of the object of the esana . Whether we can make the same claim about all forms of desire in Buddhism will be addressed later in this chapter.

\title{
Some minor terms illustrative of desire
}

The minor terms listed here are to give a sense of the range of terms for desire, but also to give a feel of the way desire is characterised - how terms with other uses have acquired a sense relating to desire. I give them here in (Pali) alphabetical order.

\begin{abstract}
Ālaya
This is a term whose use for 'desire' is only secondary to another meaning; indeed another meaning that in later thought becomes very prominent. The term älaya is given in the PED, first as 'roosting place, perch, that is, abode, settling place, house', ${ }^{245}$ and it is in this sense that later, Yogācāra thought employs it, in the idea of ālaya-vijñāna - often rendered as 'storehouse consciousness' ${ }^{246}$ However, here I am interested in its secondary meaning (presumably derived from the idea of a perch) of " "hanging on", attachment, desire, clinging, lust'. ${ }^{247}$ It is a fairly rare term in the suttas, ${ }^{248}$ although we can find this sense of alaya, such as at S.I.136, in the compound alayarama. The CDB translation gives this as 'delight in adhesion', ${ }^{249}$ while the $\mathrm{LDB}^{250}$ translates the same term (in the same context although with respect to Vipassī rather than Gotama) as 'delight in clinging'. ${ }^{251}$

However, outside its use in this context the term is a fairly rare one in this sense, and I now draw my consideration of it, and my examination of these minor terms, to an end.
\end{abstract}

\section{Keḷāā}

This term is one with a limited context and usage. Given in the PED as:

desire, greed, usually shown in fondness for articles of personal adornment: thus 'selfishness'. 252

This can be seen as a hanging-on to those things which we believe will bring us happiness, and as such rather far from desire in its usual sense. Indeed, ADP does 
not even mention 'desire' in its definition, giving it as 'cherishing, excessive concern'. ${ }^{253}$ As such, and considering it is an uncommon term, I say no more on it here.

\section{Kilesa}

A term we rarely see in Canonical literature, but whose usage is common in later compositions is kilesa. We need not expect this term to be a favourable reference to desire, as it is used only with reference to desire figuratively. Its literal meaning is 'stain, soil, impurity'. ${ }^{254}$ This term became associated with the fact that our characters are 'soiled' with certain negative features, drives and emotions. As such it is often translated as 'defilement'. As the PED states it is

tantamount to our terms lower, or unregenerate nature, sinful desires, vices, passions. ${ }^{255}$

We get an even clearer sense of this in ADP, which begins by defining kilesa as 'affliction, distress' ${ }^{256}$ In describing it more fully, ADP says that kilesa's usage relates to:

Esp. that which afflicts, that which stains; an affliction, a defilement; a defiling passion, esp. sexual desire, lust. ${ }^{257}$

It is important to note here that kilesa is often used, especially in later literature, for any of the triad of greed, hatred and delusion, or indeed to refer to them collectively. Furthermore, we should not make the mistake of taking kilesa as part of some fixed 'human nature' though. While most of us (unless we are enlightened) are indeed subject to such stains, the anicca and anatta teachings clearly indicate that there are no such fixed elements to our being. Indeed, were such stains permanent there would be no possibility of spiritual attainment - our stained natures can be cleansed with the 'detergent' of Buddhist practice. The best illustration of this is in an account of how the mind is effected by such stains:

The mind, monks, is brightly shining. But it is defiled by stains which arrive. $^{258}$

This sees negative desires as stains upon our otherwise clear mind. We can see in this idea some echoes, albeit to be understood in the context of anatta, of the Hindu idea of (re)discovering some pure inner Self. While the mind lacks many features of the atman, this view sees desire in a not wholly dissimilar manner.

\section{Jațā}

Another term with an occasional figurative use as desire is jața . While jața is literally a 'tangle of braid', and is used to refer to the tangled hair of an ascetic, ${ }^{259}$ 
it has, as the PED indicates, a desire-related usage '(the tangle of) desire' ${ }^{260}$ In the Jața Sutta (at S.I.13) we see Anto jațā bahi jațā, jațāya jațtiā pajā - 'a tangle inside, a tangle outside, people ${ }^{261}$ are entangled in a tangle'.

Again we can see desire draped in the imagery of entanglement. Like vāna, $j a t a \overline{~ i s ~ a n ~ e v o c a t i v e ~ i m a g e . ~ B o t h ~ g i v e ~ i m a g e s ~ o f ~ p e r i l, ~ o f ~ b e i n g ~ e n c l o s e d ~ a n d ~}$ unable to find our way out.

\section{Pipāsita}

We might think that we could find an example of the use of tanha in its literal sense in the Mahāparinibbāna sutta where the Buddha is thirsty, and asks Ānanda to fetch him some water. If we look to D.II,128 we find the Buddha saying to Ananda:

Come Ānanda, bring me some water as I am thirsty, and wish to drink $\overline{\text { Annanda. }}{ }^{262}$

Here we have not a form of tanhā as thirsty, but pipāsita. This is derived from pipāsā, a term for thirst. As Mathieu Boisvert notes:

The term $\tanh \bar{a}$ itself is never used in Pali literature to refer to 'thirst' as such. Instead the word pipāsa is employed when thirst is intended. ${ }^{263}$

We also find this term, albeit used less literally, in the Sangīti sutta (D. III.238.) in the sets of five, where the Buddha is enumerating obstacles to the Holy life, and a list is given of types of desiring.

Five mental bondages: Here, a monk has not got rid of passion, desire, love, thirst, fever, craving. ${ }^{264}$

The passage goes on to list various things that these 'prisons of the mind' might be directed at. Walshe, in his notes to the above translation, claims that pipāsa is used here in a way rather like tanh $\bar{a}$, but as a form of craving which is not as strong or forceful as tanhāa. In most cases the term pipāsa $\bar{a}$ is used to refer to thirst (or sometimes hunger) in a literal sense, and its figurative use is uncommon.

\section{Tanhhā: craving and desire}

Of all the terms for desire in Pali Buddhism, tanhā is the most central. Were I so inclined, the whole book could be on this single term and its occurrences in the Pali Canon. This would have been, for my purpose, too narrow, but tanh $\bar{a}$ is certainly important to this study, and I therefore dwell on it somewhat here. We find tanhā defined as:

lit. drought, thirst; fig. craving, hunger for, excitement, the fever of unsatisfied longing. ${ }^{265}$ 
The Sanskrit equivalent trșna has a similar sense. Although it seems to tend more towards the literal sense, the figurative use is still present. ${ }^{266}$ Perhaps the best known use of tanh $\bar{a}$ is in the Four Noble Truths. We find a fairly standard version of this in the Mahāsatipatthāna sutta:

What, O Monks, is (the) Noble Truth regarding the origin of dukkha? It is this craving, leading to rebirth, connected with ${ }^{267}$ pleasure and passion, finding pleasure here and there, that is craving for sensual pleasure, craving for being and craving for non-being. ${ }^{268}$

Here $\tanh \bar{a}$ is cast in its usual role - the primary root of dukkha. Elsewhere the roots of $d u k k h a$ are given a much more detailed treatment. ${ }^{269}$ While there is a significant amount of material devoted to the discussion of tanhā in the Sutta-pitaka, it is a term that crops up much more rarely in the Abhidhamma pitaka. ${ }^{270}$ Tanha comes across usually as a very negative mental phenomenon. Tanh $\bar{a}$ is that which keeps us tied to the process of samsāra, as we can see at It.15:

A man companioned by craving

Wanders on this long journey;

He cannot go beyond samsāra

In this state of being or another.

Having understood the danger thus-

That craving is the origin of suffering-

A bhikkhu should wander mindfully,

Free from craving, without grasping. ${ }^{271}$

Throughout the Pali texts, we are repeatedly recommended to destroy tanh $\bar{a}$, and its elimination or destruction is often explicitly linked with the attainment of nibbāna. ${ }^{272}$ I say relatively little here on tanha as akusala as this seems apparent it is a common view in both the Pali Canon and in interpretations of it. However, the nature of $\tanh \bar{a}$ does need a certain amount of clarification.

We can see in the passage quoted above three types of tanha given: kāma-

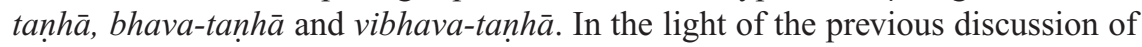
$k \bar{a} m a$, the first seems straightforward enough, although it is worth noting that here kāma is used in the sense of an object of desire, rather than as a form of desire itself; this is consistent with the way we saw it defined. But what of the other two types of $\tanh \bar{a}$ ?

Bhava-tanhā and vibhava-tanhā can be seen as representing types of craving predicated on two extreme (wrong) views, those of eternalism and annihilationism. ${ }^{273}$ That is, the first is a craving for continued becoming. We can see this on one level as the root of the urge to self-preservation - indeed we might even say Self-preservation. By this I mean that bhava-tanhā can be seen as the desire or craving to continue existing as oneself (both in this life and beyond death). Such a craving is based, it would seem, on the belief that we could 
do such a thing - it is rooted in the belief in an atman-like Self which could feasibly continue. ${ }^{274}$

Likewise, we can see vibhava-tanha as based on the belief that the destruction of the Self is possible - which makes no sense if there is no Self to be destroyed. At another level, we might read vibhava-tanh $\bar{a}$ as the root feeling of forms of aversion. It can be seen as the desire to avoid that which is unpleasant. In an interesting move, Mathieu Boisvert associates tanh $\bar{a}$ with aversion in general much more closely:

According to Buddhism, craving reflects our discontentment with the present moment, with reality as it is. We desire or crave something because of a deep inner dissatisfaction and because of our inability to accept reality as it presents itself. Craving is nothing but aversion towards our immediate situation. Similarly, aversion manifests itself as the craving for a better condition. The word tanh $\bar{a}$ refers both to craving and aversion and henceforth, whenever the word craving is employed, aversion is also intended since both are the two faces of the same coin. ${ }^{275}$

While this clearly applies to vibhava-tanh $\bar{a}$, is he right to apply aversion to tanh $\bar{a}$ in a general sense? This makes craving seem inherently negative - it is always craving for things not to be how they are. I think that on one level he is right - for in wanting something, we want what is not the case. But at the level of lived experience we do not always experience craving in this way. While my craving for a glass of whisky may be related to my current 'not-having whisky' state, I feel it as a positive wanting of something. He does however make a useful link between the nature of craving and our deep inner lack of satisfaction. This topic is discussed, in the sense of anatta and its link to desire, at some length in Chapter 5.

We saw earlier in this chapter the triad of lobha, dosa and moha as representing three negative components of consciousness. Damien Keown connects these with the nature of $\tanh \bar{a}$ :

Linked together the three root vices form what we might term 'the triangle of tanh $\bar{a}$ ', as the sum of intellectual and moral deficiency and the cause for the arising of suffering. ${ }^{276}$

Is his idea of a 'triangle of $\tanh \bar{a}$ ' sustainable? At first it may certainly seem so. We can see that moha can be seen as representing avijja , the root cause of tanha in the paticca-samuppāda explanation. Lobha represents the notion of kämatanh $\bar{a}$, while dosa could be viewed as representing vibhava-tanh $\bar{a}$ - in that it can be seen as aversion, the inverse of desire for something.

However, this is all too neat and tidy, and the terms seem rather forced into playing these roles. Kāma-tanh $\bar{a}$ seems to be something more than just lobha, and

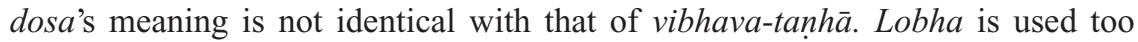
loosely ${ }^{277}$ in the Canon to play the role he gives it here, and moha seems to have 
a sense more akin to confusion and delusion ${ }^{278}$ rather than the ignorance associated with avijjā; although there may be an overlap in meaning, they are far from being synonymous. Nonetheless, this analysis that Keown offers does illustrate some of the aspects of tanha $\bar{a}$, and locates it as akusala. Furthermore, in the Sunakkhatta Sutta (M.II.258) we can see tanhā explicitly associated with dosa ${ }^{279}$ chandarāga and avijja - a similar if not identical grouping to the three 'fires' discussed by Keown:

Craving has been called an arrow by the recluse; the poisonous humour of ignorance is spread about by desire, lust and ill-will. ${ }^{280}$

This reinforces the idea that while tanh $\bar{a}$ may not be confined to the three fires, and they may not be confined to explaining only tanha $\bar{a}$, there is a significant and close association between ideas of ignorance and hatred or aversion and the notion of $\tanh \bar{a}$. This helps us to view tanh $\bar{a}$ not as a unitary negative thing, but to see it more holistically as part of a complex of mental states. This seems not only more in line with the view we find in the Buddhist Pali texts (for all mental states, not just tanha $)$, but also in line with what we might best term the 'process approach to personhood' that Buddhism advances.

In assessing the spiritual importance of desire, when looking at tanh $\bar{a}$, we come to a central point. In the process of change laid out by the Buddha, must a tanh $\bar{a}$ desire always be transformed into, or replaced by, a different type of desire before it can be viewed as kusala? One view of the Buddhist approach to desire is that one is not seeking to end, but rather to transform, desire. This idea is found explicitly in some Hindu texts, and arguably is also found in some forms of Mahāyāna Buddhism, especially in Tantric thought. In his book on Buddhist sexuality, Bernard Faure refers to this when discussing the transgression of moral bounds:

The concept of 'pivoting' or 'overturning' (Skt. paravrtti) seems to lie behind the view that rather than negating passion, desire, and sexuality, one can transmute them. ${ }^{281}$

Although Faure is claiming to discuss a 'generic Buddhism', 282 his comments on this topic are primarily supported by Mahāyāna texts. Indeed, whether the Pali texts to be studied here share the view of the Hevajra-tantra that 'by whatever thing the world is bound, by that the bond is unfastened' 283 is doubtful. That is, what evidence can we locate - if any - for the view that one must overcome a spiritual barrier through the re-direction of that very obstacle? Can we really use $\tanh \bar{a}$ to overcome tanh $\bar{a}$ ? While the Canon abounds in negative uses of $\tanh \bar{a}$, there are notable exceptions. The most striking of these must surely be that at Nettipakarana $87:^{284}$

There are two types of tanhā, skilful and unskilful. Unskilful tanhā leads to samsāra, skilful tanhā is abandonment, it leads to diminution. ${ }^{285}$ 
This is a surprising passage. Tanhhā seemed safe as a form of akusala desire, but in the light of this passage, it appears that this may not always be the case. How are we to understand this comment? Can we argue that such a claim is incompatible with other claims made in Canonical texts, such as within key doctrinal formulae? The presence of tanh $\bar{a}$ in the twelve links of paticca-samuppāda is surely not enough to mark it as inevitably akusala.

The other nidānas do not all seem to be akusala by their nature. In the broadest sense of the term we might say that all tend towards dukkha - that seems definitionally true by their inclusion in the formula. However, we do not have to see all aspects of the twelve-fold paticca-samuppāda process as inherently akusala. Indeed, it would seem problematic to talk about anything having inherent properties in the context of anatta and anicca. However, we should not mistake Buddhism's lack of what contemporary philosophers tend to call 'essentialism' for something it is not. Some things are akusala - such as the intentional killing of another sentient being, or harbouring hatred for others (or indeed oneself). How are we to marry the lack of inherent properties with the making of broad ethical and spiritual claims in Buddhism? This is not the place to enter into too full a discussion of this notion, but it would seem that phenomena can have fixed roles in causal processes - they always lead to certain results, without this compromising the notions of anatta and anicca. The notion of paticca-samuppāda allows us to move beyond an essentialist metaphysic to an ontology of process.

In the context of tanhā, the claim that there can be kusala as well as akusala forms of it is remarkable. As discussed in the overall introduction, the kusala-akusala distinction is not to be taken as purely one of type, but also as one of degree. ${ }^{286}$ Two actions, for example, can both be akusala; but waging chemical warfare on people seems significantly more akusala than using head-lice killing shampoo on a child's hair.

I will return to the idea of relative kusala-akusala judgments shortly, but now wish to consider two writers who take very seriously the notion of a kusala form of tanhāa. We saw such an idea above in the passage from Nettipakarana 87, and both writers use this in their analysis. Bruce Matthews, in his book Craving and Salvation, argues explicitly for the possibility of kusala tanhāa. In addition to Nettipakarana 87, he cites the more detailed enumeration of the types of tanha found in the Sangiti Sutta. After the three types of tanhā discussed above (kämatanha $\bar{a}$, bhava-tanh $\bar{a}$ and vibhava-tanh $\bar{a}$ ), and types of tanh $\bar{a}$ associated with the world of sense-desire, the world of form and the formless world, we find a controversial and important claim about three types of tanhā:

Three further types of craving- craving for [the world of] form, craving for the formless [world], for cessation. ${ }^{287}$

This last form of tanha $\bar{a}$, that of nirodhatanha $\bar{a}$, is the important one here. Nirodha, as cessation, is often associated with the cessation of $d u k k h a$ and is used in positive contexts surrounding the attainment of nibbāna. Is this, then, a form of $\tanh \bar{a}$ 
which aims at the Noble goal? Matthews suggests that 'Controversy surrounds the meaning of nirodha tanha ${ }^{2}{ }^{288} \mathrm{He}$ cites numerous positions with regard to this phrase, such as T. W. Rhys Davids' view that it indicates 'craving for life to end', 289 which seems rather close to the notion of vibhava-tanha $\bar{a}$. While, as discussed below, there are other views of nirodha-tanh $\bar{a}$, the Vibhanga analysis of it - where it discusses the various types of tanhā enumerated in the Sangīti Sutta- describes it in such a way as to associate it very closely with vibhava-tanh $\bar{a}$ :

What then, is craving for cessation? Passion, infatuation, infatuation of consciousness, accompanied by an annihilationistic view. This is called 'craving for cessation'. ${ }^{290}$

If we turn back a page or so in the Vibhainga, to where the triad of kamma-tanha bhava-tanh $\bar{a}$ and vibhava-tanh $\bar{a}$ are described, we find the definition of vibhava$\tanh \bar{a}$ to be identical to the above definition of nirodha-tanh $\bar{a} .{ }^{291}$

Matthews, however, also refers to Johansson's view ${ }^{292}$ of nirodha-tanhā, claiming that 'it refers to craving for the cessation of everything that is negative'. ${ }^{293}$ Matthews goes on to say that:

Others ${ }^{294}$ maintain that it [nirodha tanh $\left.\bar{a}\right]$ refers to a more noble, albeit paradoxical, craving for nirvāna. ${ }^{295}$

Now, this might, given what I have said above, not be very different from the view of Johansson - for nibbāna is, as indicated, often associated with the cessation of that which is negative. Why, though, does Matthews suggest that this interpretation of nirodha-tanh $\bar{a}$ is paradoxical? Is it the cessation of, among other things, desire that he refers to here? 'The desire to be without desire' seems to be the area he is aiming at here. I may desire that I no longer desire something negative - this does not seem inherently paradoxical. The question here is to do, to an extent, with the type of desiring - the way of desiring. Is tanha for a good object still partly akusala? In the 'way we want', in the context of tanh $\bar{a}$, is the way of wanting what may be problematic? This question will be returned to later.

Matthews then cites Nettipakarana 87, which he takes as indicating that tanh $\bar{a}$ may have a role in moving us towards nibbāna, when he writes:

This passage lends definite support to the argument that craving for nirvāna was taken to be at least partially beneficial from a soteriological point of view. ${ }^{296}$

Although he does not state it explicitly here, this indicates that tanha $\bar{a}$ is indeed capable of assuming a kusala form, as Nettipakarana 87 states, for as we saw from the definition of kusala-akusala, that which moves us towards nibbāna is by definition kusala.

This brings us to another important passage in the construction of the notion of a kusala form of tanha - the Bhikkhuni sutta. Here a nun seems to offer herself 
sexually to Ānanda, and he responds with a moral lesson. In the sutta he argues that while craving may be overcome by craving, sexual intercourse is not to be overcome by sexual intercourse:

Sister, this body has come into being through food; yet based on food, food can be abandoned. This body has come into being through craving; yet based on craving, craving can be abandoned. ${ }^{297}$

Ānanda goes on to say that this does not hold true for sexual intercourse. This seems to indicate that tanh $\bar{a}$ can be used as a basis for the abandoning of tanha Later in the same sutta, this is elaborated in more detail, where a monk has heard of another who has attained nibbāna, and responds thus:

Then he thinks, 'Oh, when shall I too realize the taintless liberation of mind, liberation by wisdom?' Then, some time later, based on that craving, he abandons craving. It is on account of this that it was said: 'This body has come into being through craving; yet based on craving, craving can be abandoned. ${ }^{298}$

Here we have an intriguing picture. The monk here has a tanh $\bar{a}$ for nibbāna, and this moves him to make the spiritual endeavours that lead to the destruction or abandonment of tanhā. Note, though, that this abandonment comes some time after the $\tanh \bar{a}$ for it. While $\tanh \bar{a}$ has a positive sense here, it is distanced from the achievement of the goal. Tanhha here can be an initial spur to moving in the right direction. I am not trying here to dismiss the importance of this passage, for if well-directed tanh $\bar{a}$ can, even in the long-run, move us towards, rather than away from, nibbāna, then we are to consider it kusala to some extent, ${ }^{299}$ as this flows directly from the nature of kusala-akusala as defined in the introduction.

Matthews refers in his discussion of this to K. N. Jayatilleke's Buddhism and Peace, where Jayatilleke argues that:

Here we should distinguish between 'self-centred desires' and a so-called 'master-desire' for nirvāṇa which 'is not on the same footing as the first order desires.' The master desire, he adds, eliminates the self centred desires, until both orders of craving are extinguished in the attainment of complete awareness. ${ }^{300}$

This approach seems initially sensible, but we do need to challenge aspects of it. Why must the 'master' form of desire be a tanh $\bar{a}$-type one? Given what is said elsewhere in the Canon about tanha $\bar{a}$, it would seem one of the least suitable forms for playing such a role.

Something such as chanda would seem much more of a likely candidate. Furthermore, it is not wholly clear here how one might go about overcoming the 'master' desire - it seems qualitatively distinct from the self-centred forms (another 
reason for not seeing tanha as the best term for both types of desire), and more needs to be said in order to sustain the view of Jayatilleke, as outlined by Matthews. Matthews himself does not seem wholly convinced either, and while admitting of the possibility of kusala tanh $\bar{a}$, is guarded about its spiritual potential:

What does need to be emphasized is that the texts nowhere assert that craving is an end in itself in the realization of nirvāna. The passages just examined (D.3.216, Nett. 87, A.2.114 ${ }^{301}$ ) show that positive (kusala, nissāya) craving can at best be seen as a stepping stone to getting rid of craving altogether. ${ }^{302}$

This seems a fairly balanced conclusion, given what has gone before.

Robert G. Morrison seems to have a more positive view of tanh $\bar{a}$ altogether. His article Two Cheers for Tanh $\bar{a}^{303}$ sets out to:

present a more sympathetic view, a view that highlights the wider implications of tanh $\bar{a}$, and contends that without it there would be no Buddhist spiritual life - no brahmacariya or 'pursuit of excellence' - and therefore no Buddhas. ${ }^{304}$

$\mathrm{He}$ is clearly going much further here than Matthews above. Morrison's piece is not just saying 'maybe tanhā can sometimes be spiritually useful', for he has a much grander role for $\operatorname{tanha}$ to play.

We saw, in previous chapters, the possible metaphysical and creative power of desire, and these notions are worth bearing in mind when Morrison claims:

To understand tanh $\bar{a}$ as simply one affect among others would be a mistake. As we shall see, tanh $\bar{a}$ is a term that has cosmic significance, and is best understood as a metaphor that evokes the general condition that unawakened beings find themselves in. ${ }^{305}$

This is an approach that Morrison takes seriously, and I will take his argument in the stages he presents it. He begins, as he must after what he says in the quote above, with an attempt to establish this 'cosmic significance', through a cosmological perspective. To see how he does this we must return to the Aggaññ Sutta, which was mentioned during my discussion of the term sārāga. As mentioned earlier, this sutta involves a situation where the beings of the world fall from a 'higher' rebirth to a gross or physical form due to desires that arise in them. Morrison sees this as almost-a-creation story, and even goes as far as to compare the sweet pudding-skin-like earth to the apple in the Biblical 'fall' - an object of temptation.

We can see then how tanha $\bar{a}$ might acquire the cosmological role he wishes to ascribe to it. It is, in this view, the engine of creation. ${ }^{306}$ Now, this is deeply resonant with many of the views I have discussed in relation to Hinduism, but can 
we apply it to Buddhism in this way coherently? To an extent we can, but we do not need the Aggañña Sutta to help us do it.

That existence - bhava - is a result of tanhā is manifest in the process of conditioned arising. ${ }^{307}$ But why pick out tanh $\bar{a}$ ? Why not some of the other factors? As we shall see, Morrison does look at avijjā, but why not some other form of desire? What is it that leads him to attribute such 'cosmic' status to tanhā? On the evidence thus far, he does seem to be overstretching the Aggañña Sutta, but he does propose further support for his claim based on the omnipresence of $\tanh \bar{a}$ within conditioned beings. After referring to the presence of tanhā in a deva in the Aggañna Sutta, he suggests that:

Elsewhere, the Buddha declares that tanhā is the 'fuel' (upādana) that links one life with the next, implying that tanha is the radical condition for existing anywhere within the Buddhist cosmos, including its higher, more refined reaches. ${ }^{308}$

This is interesting, and in many ways more substantive a point than that drawn from the Aggañña Sutta alone. However, we might question the centrality of tanh $\bar{a}$ here. It is a key factor in becoming - no sentient being comes to be without it. Now, on one level a certain class of beings does exist without tanh $\bar{a}-$ enlightened beings exist (post their enlightenment, and prior to their death) and are free from $\tanh \bar{a}$, but they would not have come to be without tanhā.

However, there are other factors involved in the process of becoming, most notably avijja . Morrison, as we shall see shortly, does try to establish the primacy of tanh $\bar{a}$ here; but even if successful, can it stand alone in the manner he seems to be suggesting? Even if we were to accept the importance of tanh $\bar{a}$ as a means of fuelling becoming, which in part is undeniable, this does not mean we are to cheer for tanhā. In the Buddhist analysis, being born is not a cause for rejoicing, but is rather a gateway to dukkha. But given the fact of our existence, even if we take a more cheery approach to life - if we are glad to be alive - should we thank $\tanh \bar{a}$ for that? It would seem that this is the way that Morrison is moving.

Morrison continues his attempt to establish a cosmological role for tanha $\bar{a}$, and does so partly based on A.V.116 where we find Purimā, bhikkhave, koți na pañ̃̃āyati bhavatanhāya - 'Monks, a first point ${ }^{309}$ of craving-to-be cannot be known'.

Morrison goes on to argue that bhava-tanhā represents the primary form of $\tanh \bar{a}$, and that $\tanh \bar{a}$ as an ever-present form, especially given its role in the Aggañ̃a Sutta, is a basic cosmological principle. In his view, the Canonical passages mentioned here lead to the view that tanha $\bar{a}$ is:

understood to be the primal condition out of which all other affects can be said to develop. Tanh $\bar{a}$, from this perspective, may be understood as the all-pervasive and fundamental characteristic of the Buddhist cosmos; its raison d'être. ${ }^{310}$ 
As Morrison wishes to establish that bhava-tanh $\bar{a}$ is in some way tanha per se, what of kāma-tanh $\bar{a}$ and vibhava-tanhāe His first position is to suggest that bhava-tanh $\bar{a}$ is the most fundamental ('the most general and basic') ${ }^{311}$ of the triad. He tackles kāma-tanha $\bar{a}$ first:

Kāma-tanh $\bar{a}$ is 'thirsting' after specifically sensual experiences and is, therefore, an aspect of the more general bhava-tanh $\bar{a}$, which is 'thirsting' after any form of being or experience - it is simply the urge to be, or, more correctly, to become (bhava). ${ }^{312}$

I am not sure we need go along with such a view. First, can we just place all sensual experience in so easily with bhava-tanh $\bar{a}$ ? It seems to me that while bhavatanh $\bar{a}$ represents the craving to be, kāma-tanh $\bar{a}$ more accurately represents the desire to have - be it an object, or an experience derived from interaction with a physical object. ${ }^{313}$ We did see, in Freud and Schopenhauer to an extent, as well as in parts of Chapter 2, the view that all individual instances of desiring derive from some general and primal form of desire, but can we here apply it to Buddhist thought with regard to tanh $\bar{a}$ ? Morrison gives no further substantial support in making this claim, and I remain unconvinced that bhava-tanh $\bar{a}$ would be the best type of desire with which to advance such a proposal.

If we come to his claim that bhava-tanha ontologically precedes vibhavatanh $\bar{a}$, he argues his case thus:

If we assume that existence does not inherently involve a Freudian 'Death Wish', then the third tanhā, vibhava-tanhā or 'thirst for nonexistence', is more likely to be the outcome of the continual frustration of bhava-tanh $\bar{a}$ and kamma-tanh $\bar{a}$, and is therefore a secondary and derived state. ${ }^{314}$

There are a number of things to take issue with here. If we look at how I defined vibhava-tanh $\bar{a}$ earlier, we do not have to see it as a 'Death Wish' - we can see it as a craving based on an annihilationist world-view, and bhava-tanh $\bar{a}$ as based on an eternalist world-view. ${ }^{315}$ Why does this make one more primary than the other?

Furthermore, the desire to avoid the unpleasant, another way to view vibhava$\tanh \bar{a}$, does not seem of necessity derived from frustration. Desires to avoid the unpleasant or seek the pleasant do not seem appropriately placed in an ontological hierarchy. The view Morrison advances here seems based on a partial misunderstanding of the nature of the three types of tanh $\bar{a}$. Finally, on this matter, even were Morrison successful in making the case for bhava-tanha as tanhā per se, and by extension, based on A.V.116, the case that the start of tanh $\bar{a}$ could not be found, what would this actually tell us? We are not informed that other mental factors $d o$ have a beginning that can be known.

Morrison's claim is that other effects flow from tanh $\bar{a}-$ it precedes them - and even were he able to demonstrate that no beginning to tanh $\bar{a}$ can be known, he 
would also have to show that a beginning could be found for those things which he believes to be effects of this primal tanha $\bar{a}$. On tanh $\bar{a}$ as cosmological principle, on the basis of the above discussion, I remain rather unconvinced.

Morrison continues in his discussion of $\tanh \bar{a}$ along a line not dissimilar to that of Matthews, in that tanh $\bar{a}$ can be seen as a spiritual tool, viewing the roots of Gotama's Noble search as rooted in tanh $\bar{a}$. While it may be the case that a $\tanh \bar{a}$ desire may lead to a quest that later becomes Noble and ultimately goes beyond all $\tanh \bar{a}$, does this indicate that all religious striving originates in $\tanh \bar{a}$ ? This is the case only if we see tanh $\bar{a}$ as desire per se. If we see it as one form of desire among many, then this need not be the case. Morrison's desire to redeem or rehabilitate $\tanh \bar{a}$ would make sense if and only if there were no other forms of desiring available. Were his attempt to make tanh $\bar{a}$ a metaphysical principle successful, he would indeed need to establish the centrality of tanh $\bar{a}$ to the spiritual quest.

In arguing for the necessity of tanh $\bar{a}$ as a force likely to motivate us towards nibbāna, Morrison might initially seem to make the same mistake as those who assert that Buddhism recommends the end of all desiring. Morrison sees tanha as the whole story regarding desire in Buddhism. He has a point regarding the very outset of the spiritual journey: that grasping after spiritual truth is better than grasping after the suffering of one's enemies. It is tempting to suggest that such a view is rather close to the Mahāyāna notion of 'skilful means', but the Pali texts are not without evidence of a similar approach. While the notion of 'skill in means' is developed greatly in later thought, we do find the Buddha engaging in 'graduated teachings', ${ }^{316}$ and other episodes in the texts supply examples of 'skill in means'.317

Further, things do not have to be the worst of all possible in order to be discouraged. Punching my doctoral supervisor on the nose is wicked, no doubt. Few would disagree that it is better than killing 20 students by bombing a canteen. Given that, however, this does not constitute grounds for saying 'Two Cheers for Punching Doctoral Supervisors'. Were tanhā the only form of desiring available to the Buddhist, Morrison would be convincing - but it is not. Morrison also makes a number of points regarding the relationship of tanha and views, ditțhi, which I address in Chapter 4.

Having spent some time looking at tanh $\bar{a}$, what conclusions can be drawn about it? The possibility of kusala-tanh $\bar{a}$ is intriguing, and to an extent seems acceptable, but it is - if we continue to view the kusala-akusala distinction as something akin to a spectrum - only just kusala. It is something we can utilise, but that which can surely only carry us so far. If we are to continue with the previous imagery, it seems like a type of desire which will soon need abandoning, or at least transforming into some other, more kusala, type to carry us much further towards nibbāna. Towards the end of this section, it begins to seem as if the prescription for $\tanh \bar{a}$ is re-orientation and re-direction. This clearly relates in many ways to the objects of desires, but the problem with tanh $\bar{a}$ is more than just its object. Clearly, also, if the goal is to overcome all craving then we cannot surely 
be seeing tanh $\bar{a}$ in too positive a light. Maybe we are, to $\tanh \bar{a}$, to see ourselves as malign hitch-hikers - letting tanh $\bar{a}$ carry us forward, only to finally reveal that we have used it to later annihilate it.

\section{Conclusion: landscapes of desire}

We have seen throughout this chapter the notion that desire, in certain forms, can form a part of the Buddhist spiritual path. We saw the notion of a desire for deliverance. While Muccitukamyatā seems post-Canonical in its development, the ideas it draws upon run throughout the suttas, and we have seen many of them here.

Some desires, such as tanh $\bar{a}$, seem in need of undermining fairly early on the path to nibbāna, ${ }^{318}$ but we may see forms of striving, which are rather akin to desires, leading us right to the brink of nibbāna. In its role in the 'bases of success', chanda can play its part also in such a process. Only when there is nothing left to achieve, once that which is to be done has been done, only then need we strive no more. ${ }^{319}$

Returning to themes introduced at the beginning of this chapter, we saw that the 'desire for the Self' found in Hinduism was either inappropriate, or at the very least problematic, in a Buddhist context.

How is desire related to anatta? This is a topic that has been mentioned a little, but that needs further comment - some of which will be found in the next chapter, and in the conclusion. It is clear that there needs to be some assessment of the relationship between the Self and desire. In Buddhist terms this is what I am doing in both this and Chapter 4. I am laying out how desire operates in the components that go to make up our empirical Self. A Vedic thinker might demand more, as may a Western metaphysician. Their demand might be that I address not the factors of personhood, but the relation of desire to the Self itself, what we might call the Self-in-itself. Now, clearly it is just such a Self-in-itself that anatta opposes. ${ }^{320}$

In proposing the anatta doctrine, we are left with only the khandhas, and I have begun to partially outline the relation of desire to the khandhas; Chapter 4 will deal more explicitly with this topic, when desire is placed into the context of the mind-body relationship. However, if there is no atta-type Self to relate to desire, there is still more to do than just understanding how desire is to be found operating within the khandhas.

If we propose that both the belief in a Self and the occurrence of negative (akusala) desire spring, ultimately, from the same root, from avijja, then we need to consider desire (and notions of Self) in the light of Buddhist understandings on opinion and belief - how ignorance and wrong-views can be removed, and how this process relates to the refining and ultimate overcoming of desire. This is one of the key goals in Chapter 4.

One key point worth making here concerns how desire and anatta relate to one another. Both are about 'lack' or 'absence'. Desire, often, involves that which we are without; ${ }^{321}$ anatta tells us that our within is without anything permanent, 
stable or reliable. Might the belief that our desires really can be fulfilled be analogous to the belief that we really are an entity which endures over time and has some sort of essence or true underlying nature? Clearly both views fail to recognise the mutability of existence, anicca.

In the light of the discussions in this chapter, what has been achieved? The most obvious conclusion one can draw regards the complexity of the Buddhist view of desire found in the Pali Canon. As demonstrated in this chapter, desire is conceived of in numerous ways and these differing conceptions have varying statuses, going well beyond the notions of good and bad desires being for good and bad objects respectively.

The main concern I have had here is with the kusala status of desires. Why am I so interested in the kusala status of desires? We can recall from the Introduction that kusala states of mind propel us away from dukkha and towards nibbāna. Surely the true worth of a mind-state is the manner in which it moves us either towards or away from misery and suffering. Furthermore, in the Buddhist viewpoint ethics, ontology and epistemology merge.

Actions - inclusive of mind-states - have particular consequences (be they kammic or due to other aspects of paticca-samuppāda); these actions make sense only when a full ontological picture is taken into account, as it is due to the nature of the universe - the manner in which it is occupied by inter-related entities - that these events have their particular results; and only through wisdom and knowledge can we become cognisant of the effects of our actions (again, mental included) and develop the means to effect successful interventions in the processes of our desiring. It is just these process-mechanics that I investigate in Chapter 4.

There are two interpretations of the diverse representations of desire we find in the Canonical texts which I wish to reject. One is that the Canon is a jumble with regard to desire. That the lack of immediate clarity is the result of an essential confusion in early Buddhist thought over the nature of desire. Despite some variant and occasionally befuddling passages, there is also much consistency and subtle debate. The second is the contrary to this - that we have in the Pali Canon a complete, coherent and comprehensive typology of desire. Would that it were so!

Not only is there the occasional aforementioned confusion, but more than this, there is still evidence of the tensions which characterised the Hindu material discussed in Chapter 2. The debates surrounding the kusala status of tanh $\bar{a}$ are alone sufficient to demonstrate this.

The Pali Canon does not fully resolve these tensions, but it does seem to go a long way towards it. While its typology is imperfect and incomplete, it shows the possibilities of such a scheme. It would be an ambitious undertaking, whereby all possible manifestations of desire were analysed, classified and assessed. Indeed, whether the approach were explicitly Buddhist, psychological or syncretistic, it may prove that the fluid and dynamic nature of consciousness would never allow such a schema to be placed over it. Nonetheless, the Buddhist material examined here, with its own dynamic meditation-based response to desire, offers the spiritual aspirant, who would engage with their desires, much to go on. 
With regard to desire then, the Canon may not be the resolution of all tensions and the repository of ultimate wisdom, but maybe it can be a signpost; a pointer towards views of desire which enrich and deepen our lives - rather than being the enemy of happiness against which we must enter constant battle mindful of the inevitability of defeat. While the next chapter addresses many of the issues arising out of the material in this chapter, it is already clear that rather than a 'paradox of desire', Buddhism offers us a partial map.

The world of our experience is in some senses made by desire - this we have seen. There seems less metaphysics in the Buddhist approach than the Hindu, and we should expect this. Buddhism is suspicious of much metaphysics, but wishes instead to present us with the means of interacting in positive ways with the desirecarved topography of existence. The Buddhist texts examined above can be seen to represent an ethical cartography, something by which to seek and navigate a path through the landscapes of desire which represent the world of lived-experience. 


\title{
4 \\ BUDDHISM AND DESIRE \\ The dynamics of desire
}

\author{
When things become manifest \\ To the ardent contemplating brahmin, \\ He abides scattering Māra's Host \\ Like the sun illuminating the $\mathrm{sky}^{1}$
}

\section{Introduction}

As we move into this chapter, it is worth pausing for a moment to consider the stage we have reached thus far. My attempt to establish a coherent and consistent typology of desire as found in the Pali Canon has been partially successful. We have seen a variety of terms and the varieties of their usage, but the picture is not always as clear as it might be, and many terms that seem in places to be inherently akusala are used on other occasions in a more positive sense.

We might read this as sheer inconsistency, but there is another approach. An alternative interpretation is to consider this as indicative of the possibilities of transmutation. This clearly echoes material discussed in Chapter 2, where the tension between notions of the removal and transformation of desire is often felt. The picture in Buddhism is not so simple. It would seem that there are two threads in this, the treating of desire-terms as generally akusala, but occasionally more kusala.

First, we can see the variation of a desire-types' kusala status, as the aforementioned potential of the transformation of desire. Second, we might also see it as recognising a qualitative distinction between two fundamentally different types of desire - but ones where the difference is hard to discern from outside of the individual concerned. This typology is not, as I have indicated, fully developed and coherent. However, one can discern in the Pali Canon the beginnings of such a typology.

The possibility of a typology of desire is complicated by the notion of the transformation of desire. ${ }^{2}$ If akusala forms of desire are capable of being transmuted, via spiritual endeavours, into kusala forms, then a typology distinguishing inherently kusala forms from akusala forms is not needed. However, neither approach is fully developed. Rather we get a taste of both, the two overlapping at times, and elsewhere one of these two approaches seems presented as the key one. It is the 
purpose of this chapter, in part, to disentangle these threads. In seeking this clarification, the possibility is left open that no such overall clarity is possible. This may prove to be the case for a number of reasons, but two seem most likely.

First, the compilers of the Canon may have left us an entangled picture. Desire is so deeply part of our being in the world, that unravelling its multiple threads and their relations with each other, and other aspects of Buddhist Dhamma, may be nigh impossible: the Canon may just be unclear on this matter.

The other possibility here is that the ideal of desirelessness is incapable of being captured by words. While this strategy has then the danger of being seen as opportunist, it may be viable in this context. For one who has attained nibbāna, desire - as we understand it as unenlightened beings - does not occur.

The wishes and aspirations of a tathägata may be so different in their very nature that there is no fully accurate and complete way to convey them in words. This might lead to the adopting of two strategies. First, the drawing of analogies between such desires and transformed versions of the desires we do have; second, the identifying of the less akusala forms of desire that are part of the psycho-emotional spectrum available to the unenlightened.

This does seem a useful approach, and may have some mileage in it, but it is not a complete solution to these tensions and concerns. It may be the case that such a relation could exist between the aspirations of a tathāgata and the desires of a puthujjana, but what of the right-desires of the 'noble ones' on the path, but who have not yet reached the goal? Can we view their kusala-desires as more like the wishes of a tathägata than those of a person not on the Path at all? Maybe we can draw, at least, an analogy between the two. However, this needs not only an understanding of paticca-samuppāda, but also may only be fully coherent from a more lofty spiritual perspective than I am here able to offer.

It may be that a notion that may reconcile these two notions of the 'removal' of desire, and its 'transmutation' is that of its 'refining'. In the notion of 'refining' desire, we may be able to elaborate a notion of change that encompasses both the removal of akusala desire and its transformation - as well as proving compatible with the partial typology uncovered thus far. A refined form of desire would have had its more akusala aspects removed, and hence appear transformed. A distinction we might draw between refining and transforming is that refining might indicate the removal of akusala elements of desire, while transforming might initially indicate the changing of the objects of desire, followed by a change in the tone of the desire, until it begins to lose its akusala aspects, and we can then consider the process of refining to have begun.

Furthermore, various types of desire would require relatively more or less amounts of refining in order to achieve the status of a fully refined, wholly kusala mental state - at which point they could be described as having been transcended. This approach will be assessed again at the close of this chapter, to see if it can be maintained in the light of what is said here about the role of desire in paticca-samuppāda and the mind-body relationship. I will further seek to see if the understanding of 'views' that emerges here has any impact on this claim. 
In examining the role desire plays in paticca-samuppāda, I was initially inclined to describe such an analysis as the unearthing of a Buddhist psychology of desire. Upon further reflection, I became a little ambivalent about describing it in such a manner.

In some ways, it may be that the approach of paticca-samuppa $\overline{d a}$ is deeply psychological; uncovering, as it does, the operation of consciousness and related states. However paticca-samuppāda is broader in scope. It encompasses a fuller account of causality than the purely mental, and - as will be discussed in this chapter - offers a philosophical insight into the nature of mind-body relations normally lacking in what is classed as 'psychology'. An investigation of desire will by its nature tend towards the more psychological aspects of paticca-samuppāda. However, it is not bordered and enclosed in as specific, formal and hard-edged a manner as terming it a 'psychology of desire' would imply.

What we can see occurring in this chapter, though, is a focussing in on the micro-level of the operation of desire. This is why I have described this chapter as investigating the 'dynamics' of desire. Previously I have been working with a broad metaphysical canvas, looking at a macro-level understanding of desire. In looking, inspired in part by Hindu approaches, at the cosmological significance of desire we have seen the notion of desire as creative. What has begun to emerge, though, is the notion that this creation occurs in terms of our consciousness playing a key part in this creative drama. In order to see what is happening in relation to desire in this macro-level process, we need to investigate the Buddhist account of its root causes. These roots lie within us. Within us are the tools by which we craft the world we inhabit. As such, desire may be a rude and clumsy tool for the forging of our experienced world, but also - I am led to think by what has been examined in Chapter 3 - it may be a more precise and subtle instrument. The investigation into paticca-samuppāda in this chapter is for the purpose of uncovering this dynamics of desire.

While my intent here is more academic than therapeutic, such an investigation should provide an insight into how we might become more skilled practitioners of wanting. If desire is one of the key means by which we fashion our lived experience of the world, this may give us the necessary means to build a world-of-experience less drenched in misery, stress and frustration.

This chapter, then, begins by examining paticca-samuppāda, and then moves on to assess the role played in the paticca-samuppāda processes by desire. The role of desire goes beyond the presence of tanhā as a nidāna in the twelve-fold formula of paticca-samuppāda, and I attempt to look at both the causes and consequences of this role in the processes of conditioning. This leads me to a concern with the mind-body relationship.

While some desires might be fairly considered as wholly occurring within the mind, many - arguably most - are for external objects, although the desire is still, of course, within the mind. Desire for an external object may be deemed as a form of the mind reaching out into the world - desire acting as a bridge between the internal and external. In order to assess such a view of desire, it is necessary to 
have as clear as possible an understanding of how the Pali Canon understands the mind-body relationship. ${ }^{3}$

Once I have sought to establish a view of desire within the context of paticcasamuppāda and begun to outline the mind-body relationship, a clearer overall picture of the manner in which desires both hinder us and motivate and assist us will have been delineated. I will move on from this to look at an element of mental life that has striking similarities to the Buddhist view of desire, in the way that it is understood in Buddhism: views. This may seem an odd topic to address at this stage, but on closer inspection it becomes evident that its akusala/kusala status and the way it is discussed seems to echo the discourse on desire that I have outlined. ${ }^{4}$

By the end of this chapter I will be in a position to try and establish an overall view of desire in the Pali Canon. This summative overview will be given in Chapter 5, where I shall also seek to engage this final picture in a dialogue with the various perspectives on desire outlined in the first two chapters of the book.

\section{The nature of paticca-samuppāda}

Were we in any doubt regarding the significance of paticca-samuppāda within Buddhist thought, we would find a stark assessment of its importance in the Mahāhatthipadopama Sutta, where Sāriputta places the following words in the mouth of the Buddha: ${ }^{5}$

One who sees ${ }^{6}$ Conditioned Arising, sees the Dhamma; one who sees the Dhamma sees Conditioned Arising. ${ }^{7}$

Here understanding of paticca-samuppāda and understanding of the Dhamma in general are seen as synonymous. To understand the true nature of things is to understand the manner in which things are related - this makes good sense, at least once we are familiar with the notion of paticca-samuppāda. But just what is paticca-samuppāda?

Paticca-samuppāda is a common notion in Pali Canonical texts, and probably the most widespread translation is as 'Conditioned Arising', or as 'Dependent Origination'. But what are we to take it to mean? The basic formula used to express the notion of paticca-samuppāda is found at M.I.262-3 as:

When this exists, that comes to be;

With the arising of this, that arises. ${ }^{8}$

The formula is completed a little later in this sutta, when we have the summary of paticca-samuppāda with regard to cessation, following the one above of arising:

When this does not exist, that does not come to be;

with the cessation of this, that ceases. ${ }^{9}$ 
This begins to give us a sense of it. Paticca-samuppāda can be, at least in a broad sense, seen to represent the Buddhist notion of causality. That is, paticca-samuppāda offers an explanation of the causal relations between the components of reality. ${ }^{10}$ If we turn to the PED, we see paticca-samuppāda defined as:

'arising on the grounds of (preceding cause), 11 happening by way of a cause, working of cause \& effect, causal chain of causation; causal genesis, dependent origination. ${ }^{12}$

David Kalupahana explains his understanding of paticca-samuppāda, while also concurring with the aforementioned view of its centrality:

The Buddha claimed that his search for the nature of things led him to the discovery of the uniformity of the causal process... It was the knowledge of the causal pattern that enabled him to put an end to all defiling tendencies and thereby attain freedom (vimutti). ${ }^{13}$

The most striking phrase here is 'uniformity of the causal process'. It is clear that paticca-samuppāda refers to causality, but in what does its 'uniformity' consist? The uniformity referred to here is surely the universality of its application. The notion of Conditioned Arising applies to all non-nibbānic experience and phenomena. All mental and physical aspects of reality are seen as operating according to this 'uniform' causal process. Not only does it explain how things come to be and end, but it does so without the need of reference to God, brahman, an underlying atta - Self - or any other such metaphysical entity.

Paticca-samuppāda, however, should not be taken as purely indicating a process of cause and effect. This is what makes it so subtle a notion - both obvious and difficult at the same time. That things come about due to causes seems, on first glance, obvious - almost a truism. What makes it a notion which is the basis of meditation, and seen as complex and hard to grasp, is that it calls on no external aspect. There is no first cause, and no guiding agency. Furthermore, it is not a teleological principle - it has no aim. The reason things come into being is that certain conditions necessary for such an arising have been fulfilled - nothing more, nothing less. Describing it in this manner makes it seem highly reductive, but as I hope emerges in this chapter, it varies in many ways from the brand of reductionism associated with Western science. ${ }^{14}$

Adding to this lack of metaphysical necessity, having only conditional necessity, is that paticca-samuppāda cannot be seen purely as cause and effect because it despite some common misinterpretations - does not ascribe effects to single causes. Discussing the twelve-fold nidāna formula (which I address shortly below), Peter Harvey makes this multiplicity of causes, or plurality of causes which need to be fulfilled, clear:

A standard formula of twelve nidānas is most common, but there are also variations on this, which emphasize the contribution of other 
conditions. These variations show that the 'that' of the abstract formula ${ }^{15}$ is not a single determining cause, but a major condition, one of several. Each is a necessary condition for the arising of 'this', but none is alone sufficient for this to happen. ${ }^{16}$

If we need extra confirmation of this claim by Harvey, we can find Buddhaghosa making the point that the process of 'arising' is not a matter of single causes and results:

Here there is no single or multiple fruit of any kind from a single cause, nor a single fruit from multiple causes, but only multiple fruit from multiple causes. ${ }^{17}$

But if this is so, does this not undermine the whole twelve-nidanna pațiccasamuppāda process? Buddhaghosa goes on to explain why it is that the Buddha gives such an explanation:

For the Blessed One employs one representative cause and fruit when it is suitable for the sake of elegance in instruction and to suit the idiosyncrasies of those susceptible to being taught. And he does so in some instances because it is a basic factor, and in some instances because it is the most obvious, and in some instances because it is not common to all. ${ }^{18}$

This makes the whole picture much clearer, if not simpler. What the paticcasamuрpāda formula expresses is an understanding of the process which might be best described as 'functional'. It identifies the main causes, the obvious ones including, in an important sense - the ones we can do something about. The Buddha's teaching of paticca-samuppāda was not a lecture in philosophy for the curious, but the unfolding of a method to achieve a goal. With this in mind, we need not take Buddhaghosa's comments as unsettling or undermining what is found in the paticca-samuppāda formulae throughout the Canon.

So, paticca-samuppāda is to be understood as a universal and uniform explanation of 'the functioning of phenomena'. ${ }^{19}$ However, as we might expect, given the pragmatic focus of Buddhist concern, this notion is applied with the greatest intensity on the process of how we come to be reborn in this world of pain, misery and frustration.

This most widespread application of the principle of paticca-samuppāda concerns the aforementioned twelve-fold nidāna formula. It is clearly going to be useful here as we can see that tanhā, and other relevant terms, crop up within it. It is stated at numerous points in the Canon, such as in the Mahātanhāsankhaya Sutta. I discuss some of the links in more detail later in this chapter, but give the twelve-fold formula now as the basis for an understanding of paticca-samuppāda:

So, monks, with ignorance as condition formations arise; with formations as condition consciousness arises; with consciousness as condition, 
mind-and-body arise; with mind-and-body as condition, the six sense-bases arise; with the six sense-bases as condition, contact arises; with contact as condition, feeling arises; with feeling as condition, craving arises; with craving as condition, grasping arises; with grasping as condition, becoming arises; with being as condition, birth arises; with birth as condition, ageing and death, sorrow, lamentation, suffering, grief and despair come to be. This is the means by which this entire mass of dukkha comes to be. ${ }^{20}$

Here we have a formula beginning with spiritual ignorance, and leading us, through these various elements, to the unpleasant circumstances in which we now find ourselves. Unless we attain nibbāna, this gives us a picture of our past, present and future.

Within this process, the most obvious concern in this current context is the appearance of tanh $\bar{a}$ at link number eight. Tanh $\bar{a}$ arises dependent on vedanā feeling. It is in response to incoming (and internal) sensation that tanha comes about (although in the light of other conditions as well). Tanh $\bar{a}$ acts as a primary condition for the arising of upādanna - attachment or grasping. Feeling is reliant on the contact of sense with sense-objects. The stages prior to this can be seen as requiring some explanation. That the six-sense bases rely upon our possession of mind-and-body (nāmarūpa) is fairly clear, but how are we to understand that nāmarūpa is reliant on consciousness?

Such a connection has to be seen in the context of the Buddhist notion of rebirth, and accounts of how one comes to be. In the production of nammarūpa, we can see viññana as that which allows their development in the womb, as we can see put explicitly in the Mahānidāna sutta:

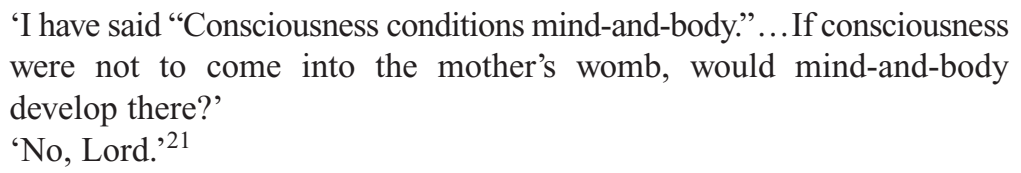

Here we can see how it is that the presence or arrival of viññana is a prime condition for nāmarüpa's development. When there is the appropriate union of the father and mother of a child, at the appropriate time, there still needs to be viññana present for conception to occur. The term usually used is not viñnāna though, but the being to be reborn: the gandhabba.2 Can we see viññanna as the link between consciousnesses - between lives? David Kalupahana, with reference to D.II.62f, claims:

All this is evidence that it is consciousness that serves as a connecting link between two lives, and this, of course, is unequivocally stated in the early Buddhist texts. ${ }^{23}$

Kalupahana goes on to cite D.III.105, where one of the attainments discussed is the ability to view viññanna-sota ${ }^{24}$ - the moving from one life on to another in 
other sentient beings. The connecting of life-to-life by viññana, then, makes reasonable sense in the context of the paticca-samuppāda formula outlined above. ${ }^{25}$

Furthermore, consciousness (viññanna) continues to condition nāmarūpa throughout life. We can see this with relation to the young, as D.II.62-3 continues from the passage cited above:

'And if consciousness of such a tender young being, boy or girl, were thus cut off, would mind-and-body grow, develop and mature?'

'No Lord.'

'Therefore, Ananda, just this, namely consciousness, is the root, the cause, the origin, the condition of mind-and-body. ${ }^{26}$

As Harvey states, 'This shows that discernment ${ }^{27}$ conditions the sentient body not only in the womb, but also during life. ${ }^{28}$ The relationship of viñ̃āana and nāmarūpa is, as with paticca-samuppāda relations in general, complex, and at times the conditioning can be seen to be mutual. We can see this in the Mahäpadāna sutta, where Vipassī, ${ }^{29}$ as a bodhisatta prior to his attaining Buddhahood, is reflecting on the processes of paticca-samuppāda:

Then indeed, monks, the bodhisatta Vipassī thought this:

'What now would it be for consciousness not to exist, the cessation of what brings about the cessation of consciousness?'

Then indeed, monks, through wise attention the following insight came to be known to the bodhisatta Vipassī:

'Through there not being mind-and-body, consciousness does not exist, the cessation of mind-and-body leads to the cessation of consciousness. ${ }^{30}$

This is a reversal of the normal approach, and indeed in the text follows the more usual assertion that nammarūpa is then dependent on viñ̃āna. The two views are not in tension though, for rather we might see their conditioning relationship as mutual. We might think that this is partly so because viññana is surely part of nāma to an extent, albeit an aspect thereof able to be understood separately from the nāma-rūpa complex. However, this does not seem to be the case. Viññanna does not seem to be part of nāmarūpa. As Harvey states:

näma refers to those non-physical states of a person, apart from discernment [viññanna], which are always present, thus comprising basic sentience. ${ }^{31}$

He goes on to outline how viññana relates to the nāma aspects of a person:

For the 'early Suttas', then, the most important dividing line within personality was not that between the non-physical (arüpa) and the physical, but between discernment and the rest of personality, mental 
and physical: the 'sentient body' (kāya or nàma-rüpa), of which

discernment is seen as the 'lord'. ${ }^{32}$

Issues raised by this will be explored further when I come to the mind-body relationship later in this chapter.

In looking here at the notion of paticca-samuppāda, we have been able to see the manner in which this process is seen as operating. I could explore the processes of paticca-samuppāda further, but this would be a major undertaking, and I need here to retain my focus on desire. What is important in the current context is to see how desire fits into this picture.

\section{Desire and paticca-samuppāda}

Clearly, the most obvious role of desire in the paticca-samuppa $\overline{d a}$ process is that played by tanh $\bar{a}$ as one of the nidānas. We saw previously that tanha arose conditioned by feeling, and itself acted as the primary condition for the arising of 'attachment'. While this makes sense, it is best viewed in the context of the overall definition of tanha in the Pali texts.

Why does this need addressing again here? Because if we consider the feeling-craving link, we might be tempted to speculate that there is a problem here. For indeed many feelings can be clearly seen to link to the arising of a related desire, but can all? Clearly the link can be broken, such that we do not respond to the feelings we derive from our sensory contact with the world in such an akusala manner. But even leaving that aside, might not some feelings lead to responses other than desire or craving? While a pleasant feeling may lead to a craving for the pleasant object, an unpleasant feeling may well be more likely to illicit aversion to something, rather than a craving for it. We find this in texts such as the Chachakka Sutta:

When one is touched by a painful feeling, if one sorrows, grieves and laments, weeps beating one's breast and becomes distraught, then the underlying tendency to aversion lies within one. ${ }^{33}$

This is why we need to return to the three classes of craving enumerated in the textual accounts of tanhā. In Chapter 3, I cited the three types of tanha as found in numerous locations, including the Mahāsatipatțāna sutta, as kāma-tanhhā, bhavatanha and vibhava-tanh $\bar{a} .{ }^{34}$ We can see how a pleasant feeling may well lead to $k \bar{a} m a-\tanh \bar{a}$, but what of an unpleasant feeling? Perhaps the best way to understand the aversion that such a feeling is likely to arouse is as vibhava-tanha . While we may not, on a surface level of consciousness, experience aversion as 'craving for nonbeing', we might also see the broader scope of vibhava-tanha as including the desire to avoid things we dislike, to be free from painful or difficult circumstances. ${ }^{35}$

The feeling however does not, of necessity, have to lead to any of these forms of tanh $\bar{a}$, for the feeling itself is not identical with the craving. It is at just such 
a point that we can plainly see the scope for meditative interventions. While the overall process of paticca-samuppāda can be addressed - especially its root of avijj $\bar{a}$ - it is this response to the feelings generated by sensory interaction that would seem most open to our own interactive manipulation via meditation.

This is a critical stage of the process. When phassa (contact, stimulation) occurs in relation to one or more of the six sense bases, we have, as it were, an incoming sensory occurrence (even if from the non-rüpa sense-base of mano). What is then generated within us at this stage is vedan $\bar{a}-$ a feeling, whether of pleasure, pain or neither-pleasure-nor-pain. It is with this as condition that we have the arising of the key stage here - the arising of tanh $\bar{a}$. This makes clear that it is how we respond to vedan $\bar{a}$ that is critical. ${ }^{36}$ Indeed, Lama Anagarika Govinda cautions us against seeing vedanā as leading, of necessity, to tanh $\bar{a}$ :

Sensation (vedanā) is not the 'cause' of craving (tanhā) and still less is craving the necessary consequence of sensation. ${ }^{37}$

We have the opportunity to step aside from our habitual responses, to prevent our response leading on to upādāna (attachment, grasping, clinging), and to find a means of responding to sensory input that does not lead to attached states of mind towards the objects of experience. Of course, by 'sensory input' here we must continue to understand this as a broader notion than that of, say, A. J. Ayer's idea of 'sense datum', ${ }^{38}$ for the six sense bases represent this wider idea of the five physical, or conventional, senses along with the idea of mano, 'mind-organ'.

What is intriguing here is just how mano operates in this context. It is not merely a receptacle for the empirical world - it is not a bucket into which the senses are poured, and although 'mind' will be addressed in more detail later in this chapter, we need to understand here its role within the idea of the sense-bases. We could see it in terms of being a set of mental events which we become aware of, ${ }^{39}$ but how does this link with the idea of the arising of phassa based on it? Were one to take such a view - that mano is the sense that perceives the mental content, separate from mano - there might well be the danger that one would then begin to think of a Self which is distinct from mano, where the mind is the object experienced with a discrete Self as the subject. This is too fragmented a view for the approach taken in the Pali Buddhist approach. Not only is there the danger here of developing an erroneous atta-ditthi, but also, as will be demonstrated later, the holistic or integrated approach to mental functioning taken in the texts opposes such a distinction.

We may do better to see the role of mano in a different light. Rather than treating it as an equal member of the six sense bases, we might view it as having another role. We might view mano in the role of integrating the five senses into a experiential whole. Here mind is what transforms the complex jumble of rapidly arriving sense-data (here Ayer's notion seems more appropriate) into the experience of the senses that the person is subjected to. While mano also has objects of its own, concepts, memories and the like, we might, if of a Kantian bent, say that 
mano is what turns the interaction of the world of noumena and our senses into that which we experience as the phenomenal world. Harvey suggests this very role for mano:

Buddhism emphasizes that, whatever the external physical world is like, the 'world' of our actual lived experience is one built up from the input of the five senses, interpreted by the mind-organ. ${ }^{40}$

Here mano has a role quite distinct from that of the other sense bases. It is, then, through the interaction of this complete 'perceiving system' that we develop the vedan $\bar{a}$ that craving is a response to. The MLD translation of the Sammā-ditthi sutta - wherein the six sense bases are enumerated - has an interesting explanatory note on the nature and role of mano in this context:

Mind-base (manāyatana) is a collective term for all classes of consciousness. One part of this base - the 'life continuum' (bhavanga) or subliminal consciousness - is the 'door' for the arising of mindconsciousness. $^{41}$

Here we get a view which seems, if not at odds with that of Harvey, at least with a different emphasis. But what do they mean here by 'mind consciousness'?

Mind consciousness (mano-viñ̃āạa) comprises all consciousness except the five types of sense consciousness just mentioned. It includes consciousness of mental images, abstract ideas, and internal states of mind, ${ }^{42}$ as well as the consciousness in reflection upon sense objects. ${ }^{43}$

So, if the ear-base leads to ear-consciousness (as is frequently said in the suttas), ${ }^{44}$ we might expect the mind-base to lead to this notion of mind-consciousness. There may be problems with this view though. First, and most obviously, viññana precedes the sense bases in the twelve-fold formula of conditioned arising. However, we do not need to see the formula of conditioned arising in severely linear form. While viñ̃āna in general may arise at an earlier point in the process, these specific types of viñãana do seem dependent on the presence of the sense bases for their arising. Furthermore, this sequence is not followed slavishly in the texts themselves. As Bruce Matthews points out when he is arguing against the view (of E. R. Saratchandra) that viññana's early place in the sequence implies that it possesses a narrow meaning of just 'sensation'. Matthews sees the twelve-fold sequence in broader terms:

Saratchandra's notion that the traditional cause and effect sequence of factors prevents viñ̃āna from bearing a developed sense of consciousness seems to reflect an excessively mechanistic view of the sequence. ${ }^{45}$ 
Matthews goes on to point to passages such as M.I.293 where viññana appears later in the sequence. ${ }^{46}$

Second, seeing mano as just another 'sense-organ' seems to leave out the notion of mano as an integrating principle of experience. Furthermore, as suggested above, what is it that has ${ }^{47}$ the experience of manoviñ $\tilde{a} n a$ ? If we were to see the five rüpa bases as integrated by the manayatana, it would follow that the five consciousnesses arising from them might be likewise integrated by manoviñ̄anna, but this is not really the issue. The key point here is to avoid a too simplistic view of the nature of mano, as Matthews suggests:

misunderstanding also arises from an inadequate appreciation of the role of mano as a 'sixth sense' in Buddhism.... But although mano is one of the senses, it must be emphasized that, in a special way, it is more than this; mano is the 'integrator' or matrix of the other senses. ${ }^{48}$

It is this more holistic ${ }^{49}$ and integrated approach to the role of mano that seems the most sustainable. Indeed the use of mano in the Pali texts does give it this wider role. At M.I.191 it is attributed a role sitting between the existence of a sense object and the experience of it; that is, mano is what leads from a raw piece of external reality to our conscious experience thereof:

when internally the mind is intact and external mind-objects come into its range and there is the corresponding (conscious) engagement, then there is the manifestation of the corresponding section of consciousness. ${ }^{50}$

However, it is worth noting that the text also gives parallel statements on the five senses as well: about the eye, the ear and the like. However, that does not prevent us from seeing mano as a sensory organiser, as well as a sensory-receptor for mind-objects. What is also revealing of the role of mano is that it is, unlike other sense-organs, in need of special levels of 'guarding' or mindfulness. All the sense-doors need 'guarding', but mano seems in need of particular attention. We can see this in the Dhammapada:

One should guard against agitation of the mind, one's mind should be of good conduct, giving up bad-conduct of the mind, one should be of good-conduct of the mind. ${ }^{51}$

Here the mind is seen as capable of good and bad conduct - much more than a mere organ of the senses.

R. E. A. Johansson offers a detailed analysis of mano wherein he asks a number of questions. In response to asking 'Is mano consciousness?' he observes that while it is given as a 'sense', passages such as $\mathrm{Sn} .834^{52}$ indicate its capability for thought, leading him to the conclusion that 'Mano is therefore a center for conscious processes. ${ }^{53}$ 
Johansson goes on to offer support for the integrating of sensory experience as a key role for mano, arguing that mano responds in such a way as to be this integrator, or as he puts it:

Mano is, therefore, a coordinating center for the other senses, and perhaps an instrument for recollecting past events (= memory). ${ }^{54}$

This matches with what has been argued above, but this notion of mano as a means of accessing or recalling memories is interesting. One presumes that this is when this integrative instrument is turned at inward data - and makes sense of prior impression - away from its usual role of marshalling its resources to offer an integrated view of new, incoming impressions.

If we see the notion of a 'mind-door' process alongside that of the other five sense-door processes, this may give an insight into the nature of mano. While there is not the space here to get drawn into the complex ways in which Abhidhamma understands the perceptual process, ${ }^{55}$ it may be useful in one respect. In seeking to see how mano sits alongside the other five senses, we might learn more by seeing what the objects that enter consciousness through the mind door are. That is, who comes knocking at the mind-door? At numerous places, we see that it is a mental object, as Lance Cousins reminds us:

But what is the object at the mind door? Traditionally it may be any kind of object - past, present or future, purely conceptual or even transcendent. In the normal case, however, it will be either a memory of the past or some kind of concept. ${ }^{56}$

This gives us a further sense of the manner in which mano is seen to operate; mano is not only a means to process raw sensory data, but also a means by which mental objects are dealt with.

Mano then has a key and varied role. It is involved in perception, that much is quite obvious, but it also needs focussing on in relation to the notion of 'heedful attention'. As Johansson suggests, 'the phrase manasi-karoti is used in many forms to express attention'. ${ }^{57}$ The Dhammapada passage above also indicates an active role for mano, giving it a sense of thinking, but also an ethical component. This leads us far away from it just being a naive notion of the brain as a senseorgan (although I am not convinced that it rules out this forming part of its broad and inclusive definition), and to concur with Johansson's view of mano:

Mano is generally conceived as an active agency, not only as a sense, content with passively receiving impressions and passing them on. ${ }^{58}$

If we look further, into Abhidhamma analysis of this, we find lengthy if not always that enlightening discussions in the Vibhanga. After a fairly predictable account of the bases, albeit very detailed, there is an account of the 'elements' 
(dhātu). These are given (Vibh.82) as 'extension, cohesion, heat, motion, space and consciousness' ${ }^{59}$ This would seem of little relevance to the current discussion, but if we look beyond this to the more detailed sections, we find the more detailed twelve-fold account, which contains the notion of the 'mind-element', the mano-dhātu. ${ }^{60} \mathrm{U}$. Titthila's translation of this gives an interesting view of mental activity in relation to the sense-experience (such as eye-consciousness) arising from the interaction of the sense bases and contact :

Therein what is mind-element? Immediately after the cessation of the eye-consciousness-element that has arisen there arises consciousness, mind, ideation, heart, lucence, mind, mind base, controlling faculty of mind, consciousness, the aggregate of consciousness; and, depending on the aforesaid, mind element. ${ }^{61}$

Interestingly, the same series occurs after the other sense-consciousness-elements (such as tongue-consciousness-element) - all lead to these various mental events including the mind base. Here we see a more complex and mutually conditioning picture than in the basic twelve-link formula. While there is not the space here to follow this up in greater detail, it does seem that upon closer examination the five physical/conventional senses spark within us the setting in motion of mano - and it is through the mano-managed response to phassa that we come to consciousness of an object of experience. ${ }^{62}$

Vedanā makes sense in this context not as just a neutral collision of the world and our sense-apparatus, but the feeling that vedan $\bar{a}^{63}$ refers to is the subjective (in the sense that it is mind-negotiated) manner in which we experience the world. It is this world that we tend to respond to with craving - not to the world-as-it-isindependent-of-us-perceiving-it. This now ties in much more clearly with the idea of ignorance as a key factor.

Craving then is not inherent within us in the sense of a fatal flaw, or some aspect of human nature ('sentient-being nature'?), but can be much more clearly understood as, in part, due to the way we view the world. This gives a pragmatic justification to Pali Buddhism's seeming pre-occupation (at least in Abhidhamma texts) with the process of perception. Greed and craving, the villains of the desire pantheon, do not arise spontaneously, but are - to a large extent - the result of a process where our perception of 'reality' is skewed and distorted by an ignorance of the nature of the world. ${ }^{64}$ At a most fundamental level this ignorance is surely of the three marks - anicca, dukkha and anatta. It is these conditions - of incoming sensory experience processed in a manner conditioned by our deep ignorance of the true nature of things - that lead to craving.

If we consider tanha as based on feeling, does not desire - at least in this form seem to be primarily reactive? Such a view is not as helpful as it might seem. If we see it as reactive because it is dependent on conditions, because it is a response to feeling, then everything has to be also seen as reactive - for everything in this world, nibbāna excepted, is conditioned. Therefore we need not see the necessity 
of conditions for the bringing about of desire as indicating that desire is somehow passive.

Having seen how tanh $\bar{a}$-desire fits into the twelve-fold paticca-samuppāda formula, we still need to see how else we can see it playing a role in the processes of conditioning. Following tanhā in the twelve-fold approach is upādāna. This term has been discussed in Chapter 3, but it is via it that we reach the final triad of the twelve-fold formula. I group the last three together as they collectively demonstrate one sense of the power of desire.

The power of desire was a central theme in Chapter 2, and may seem to have taken something of a back seat in the Buddhist analysis thus far, but it is through the conditions of tanh $\bar{a}$ and upādāna that we are led to coming into being and being born, and therefore continue to be subject to ageing, death and other assorted unpleasantnesses.

In the context of rebirth, we can see the power of desire fully uncloaked. What this brief analysis of Conditioned Arising has done is to let us see beyond the nature of desire, as discussed in Chapter 3, on to the consequences of desire and its roots. We can now see the full sense of what is indicated by the second Noble Truth; how desire as craving and attachment leads to dukkha in the broadest sense by delivering us repeatedly into this world. Matthews has recognised this vital aspect of the operation of craving:

\begin{abstract}
Perhaps the most striking feature of the rebirth process is the central role craving has in necessitating or provoking it, as well as transmitting the energy that characterises rebirth. In this way craving takes on an importance not just in the present life but in the whole structure of samsāra. We can say with confidence that, more than any other factor, craving 'turns the wheel'.65
\end{abstract}

He seems clearly right in his first comment here, but is craving as pre-eminent as he suggests by the phrase 'more than any other factor'? It is certainly one of the most critical, and as I have suggested here one where we have - along with avijja a significant opportunity to effect an intervention. Nonetheless, we must be wary of raising tanh $\bar{a}$ to too high a status, lest we begin to mistake it for a notion of 'human nature'. Craving does indeed 'turn the wheel', or act as 'fuel for the fire', ${ }^{66}$ but it can act as such only in the context of spiritual ignorance - avijja ${ }^{67}$

An illustration of the power of tanha $\bar{a}$ which has much populist application in the Buddhist world, but which for me seems charged with poignancy, is related to a specific type of rebirth born of craving, greed and attachment. That is, the fate of petas - 'the departed'. We can view this unfortunate post-death fate as an embodiment of the consequences of desire.

Often described as 'hungry ghosts', ${ }^{68}$ petas (Sanskrit: preta) are those whose attachments to this world are so strong that at death they do not attain a 'fresh' rebirth, but remain close to their previous lives as tortured spirits. The term is linked to that used in the Vedas to refer to "spirits' ${ }^{69}$ - especially in the sense of 
those who attain the realms of the fathers, but also as what we might commonly refer to as ghosts. ${ }^{70}$

Popular belief represents some forms of these beings as having huge bellies but tiny mouths - a true embodied form of the nature of craving. The seventy-fourth dilemma ${ }^{71}$ of the Milindapañha, concerns offerings to the dead, and gives an insight into the types of petas. Rhys Davids' note, in his translation, also helps us see petas without making the error of attributing to them a 'soul of the departed'-type status. He writes of petas that they:

are not ghosts, disembodied 'souls', but new beings whose link of connection with the departed is 'not soul', but Karma. ${ }^{72}$

While we may feel him a little over-pedantic regarding the term 'ghosts', it is interesting to see them as 'new beings' - for they are often seen as closely connected with the 'old being' - but then, new born children may be seen to exhibit ingrained personality traits from their preceding existence. As so often in a certain style of post-Canonical text, Milinda's questions seem to revel in foul details, talking of the petas who live on vomit and the like, but two of the categories of peta are dominated by hunger and thirst, or just thirst. The state of petas is often seen as deeply miserable (see M.I.76), but is still seen as preferable at times (such as at M.II.193) to the animal realm. I have only been able here to touch on the state of petas, but it is worth noting that this sub-human birth is seen as particularly characterised by the thirsting and craving that we will need to eliminate to go beyond, or maybe above, human birth.

We have, then, seen here how desire can be understood in the context of Conditioned Arising. But to see desire more fully we need to not only see what it is, as discussed in Chapter 3, and how it is a cause and an effect, as above, but also examine 'where' it is. Where is it that this thing 'desire' occurs? This leads us to consider the site of its arising - the nama-rüpa complex.

\section{The mind-body relationship}

The analysis offered so far in this chapter has seen how forms of desire relate to paticca-samuppāda. In the twelve-link nidāna process, we saw tanhā as the result of various conditions being fulfilled. One of these, and surely one of the most interesting, is nama-rüpa. This term is sometimes translated as 'name-and-form'the literal translation, but may also be, and often is, rendered as 'mind-and-body'. We can perhaps see it as an overall term for referring to the five khandhas, as the combined elements that go to make up a person. ${ }^{73}$ It is within this näma-rūpa complex that desire arises, and in order to gain an overall picture of desire, we need to examine this site of its arising.

The relationship between mind and body is an important topic in Western philosophical thought, and Indian philosophy has also wrestled with the complex questions regarding the way mind and matter, the mental and the physical, relate 
to each other and interact. To draw together the threads of our view of desire here, it is therefore necessary to gain an understanding of the Buddhist view of this relationship.

Clearly this issue has relevance for more than desire. The relationship between mind and body will indicate to us whether or not, for example, it makes sense to think of mind as existing without body, ${ }^{74}$ or whether the distinction between an unenlightened and an enlightened being can be understood in terms of the types of $d u k k h a$ they can be subject to (the enlightened normally being considered as capable of suffering only physical $d u k k h a$ ).

Some older Western stereotypes of Buddhism saw it as a religion of harsh asceticism. However, there is a clear rejection of extreme forms of spiritual practice. In accounts of the Buddha's life, we see him try such methods and find them ineffective as a means to spiritual satisfaction or liberation. In the Mahāsaccaka sutta, prior to taking up the path that finally leads to nibbāna, the Buddha rejects the extreme methods he has been trying:

Indeed, by these severe austerities I have not attained super human-states, ${ }^{75}$ any discrimination in knowledge or insight fit for the noble. I wonder, could there be another path to awakening? ${ }^{76}$

So, the body is not to be tormented or subject to extreme action such as starvation. In the same sutta, we find an excess of the pursuit of sense-pleasure likewise rejected, ${ }^{77}$ and the distinctive middle-way outlined. As a result of this approach we can presume an attitude to the body that refrains from seeing it as something to be defeated in this harsh manner. ${ }^{78}$

However, this view of the body is not to be taken, as a result of this, as wholly positive. Indeed, we often find it described in considerably less than glowing terms. Reflection on the foulness of the body is a common strategy for trying to free us from attachment to the body. This is often in conjunction with deeply graphic descriptions of the body after death, such as in the Satipatthana sutta, where the dead body, eaten by worms, jackals and the like is compared to the body of the living:

This body, indeed, is of the same nature, it will be thus, it is not exempt. ${ }^{79}$

This rams home the message of the transience and fragility of our embodied existence. Buddhaghosa seems almost a little too keen to reinforce this in the Visuddhimagga. ${ }^{80}$ We might view the rejection of extreme asceticism and this viewing of the body as something gross and unpleasant as being in tension. Overall though, we can see the two as compatible. The former is the judgment that these practices cause unnecessary dukkha, the very thing that Buddhism seeks to avoid, and as an ineffectual means to spiritual progress there can be no justification for recommending or indulging in such practices.

The latter is, one presumes, an approach to the body which seeks to undermine our deeply seated attachment to both the body and the pleasures which are 
channelled to our consciousness via the sense-doors of the body. These attachments are problematic due to the fleeting nature of the body and its health, and likely to lead us to further dukkha.

Before I continue though, it is incumbent upon me to take a look at this näma-rūpa entity, this temporary collection of conditioned phenomena that is what 'we' are. To do so I will begin by looking at nāma and rūpa individually before trying to see how they operate together.

Following from the discussion above, I begin with rūpa. Rüpa is most essentially a term for 'physical form' ${ }^{81}$ The PED gives it as 'form, figure, appearance, principle of form, etc' ${ }^{82}$ While its usual application is to the physical form of persons, it is also used to refer to materiality in general. This materiality is seen as made of the four great elements of matter: ${ }^{83}$ the earth element, the water element, the fire element, and the air element. As we might expect, commentarial and Abhidhamma literature is happy to expand these categories in some detail, ${ }^{84}$ where a distinction is made between these primary elements and 'derived' forms of materiality. ${ }^{85}$

Mindfulness of the body is a vital component of Buddhist meditation practice, often initially based on observation of the breath. However, beyond the breath, awareness and paying attention to the body and its functioning can have great spiritual value. Citing S.V.158 and S.V.182, and referring to M.III.99, Gethin comments that:

In a rather similar way, for the bhikkhu who develops mindfulness concerning the body ten benefits (ānisams $\bar{a})$ are to be expected; the last of these is the destruction of the a asavas. $^{86}$

Clearly the body, if not a wholly positive entity, has some role to play in the spiritual life then, if its contemplation can be instrumental in this manner.

Nāma is literally 'name', and is used throughout the Canon to refer to people's names. However it is also widely used to refer to the non-material aspects of a person. Of the five khandhas, four of them are covered by näma: vedanā, sañña sañkhāra and viññana ${ }^{87}{ }^{87} \mathrm{It}$ is when these are combined with rūpa that we are able to coherently talk of a 'person' being present. The PED states this, but adds an intriguing gloss:

These $^{88}$ as the noëtic principle combined with the material principle make up the individual as it is distinguished by 'name \& body' from other individuals. Thus nāmarūpa $=$ individuality, individual being. These two are inseparable. ${ }^{89}$

While the bulk of this comment seems wholly in keeping with the usage of namma and rüpa in the Canon, the last sentence is surely more controversial. It may seem a perfectly sensible claim, as one would expect that, in our current scientific view of persons, nāma is conditionally contingent on the presence of rüpa. Certainly a number of scholars take this view, Kalupahana feeling it to be a relatively settled matter. Discussing the process of rebirth and the manner in which consciousness 
may act as the link between lives, he writes:

It is important to note that in the early texts ${ }^{90}$ there is no mention of this consciousness surviving even for a moment without the support of a psychophysical personality. In other words, early Buddhism does not contribute to a theory of disembodied existence. ${ }^{91}$

This is in keeping with a general Buddhist theory of mind and matter as deeply entangled and intertwined within the entity of a person. ${ }^{92}$ We do find much to support this view in the Pali Canon, but perhaps the clearest summary of this is to be found in the Milindapañha, ${ }^{93}$ in a dilemma posed by the King entitled the Nämarüpa-patisandahana-pañho - 'the question of the rebirth as name-and-form':

The King said 'Honourable Nāgasena, you were talking of name-and-form just now, but what is "name", what is "form"?'

'It is this way O King; what is gross, ${ }^{94}$ this is form. What is subtle, mental, ${ }^{95}$ this is name.'

'Honourable Nāgasena, why is it that name is not reborn alone, or form alone?'

'O king, these are closely connected to one another, they are of a nature to arise together.'

'Provide me a simile.'

'It is as with a hen, O King, an embryo ${ }^{96}$ would not come to be separately, an egg ${ }^{97}$ would not come to be separately. Both are closely connected to one another, arising into being together. In this very way, $\mathrm{O}$ King, if there were no name, there would be no form; Name and form are both closely connected with one another, arising into being together. They are as this as they run through all time.'

'You are ready, Nāgasena.' 98

Here, in Nāgasena's usual manner, we find a clear statement of the mutual reliance of nāma and rüpa. There does seem to be a problem though. Nāgasena seems to be either unaware of (which seems unlikely), or forgetful of, the formless realm (a rebirth destination where we have no rüpa), as well as - inversely - the state of cessation where mind stops. If we take the above view of the nama-rüpa relationship to refer to just käma-loka rebirths, the argument may be seen to lose much of its force. I shall return to this issue shortly.

Summarising the view given in the Pali texts, Peter Harvey claims that this deep inter-connectedness of näma and rüpa prevents Buddhism from becoming a form of mind-body dualism:

While näma is centred on citta and rüpa is centred on the 'four great elements', there is no dualism of a mental 'substance' versus a physical 'substance': both nāma and rūpa each refer to clusters of changing, interacting processes. 
The processes of näma and rūpa also interact with each other, from the moment of conception, mutually supporting each other. ${ }^{99}$

While this seems in line with the view outlined throughout this section, Harvey makes a more intriguing claim:

The Pāli suttas (though not later Pāli material) includes indications that the early Buddhists regarded consciousness (viñ̃āna) as able to 'break free' of the network of interactions. ${ }^{100}$

This can be seen to have other implications (such as for the nature of nibbāna), but also is interesting with regard to the 'formless realms' - where viñ̃äna is separate from both rüpa (which is not present) and nama, but is still conditioned by mental factors which are part of nāma. While Harvey uses this notion, in a variety of pieces, as the basis of his approach to nibbāna, the viability of nāma, or at least elements of nàma, existing independently of rüpa is challenging. Many, under the influence of reductive Western science, see 'mind' as somehow dependent on the physical brain; be this in terms of identity theory, or seeing mind as some kind of epiphenomenona of the brain.

The idea of elements of our mental make up being able to exist independently of the physical is hard for us to grasp, but the suttas are suggestive of such a possibility. Some of the powers of arahats such as mind-projection and mind-sharing seem to break aspects of nāma away from its rūpa conditions. ${ }^{101}$

We also need the notion of there being the possibility of nàma breaking away from rüpa, if the aforementioned notion of a 'between-lives state' is to be viable. ${ }^{102}$ Clearly some take the view, as Kalupahana does above, that such a state is incompatible with the stance of early Buddhism, and it is not accepted by Theravāda orthodoxy. But if we were to accept the possibility of separation, such a notion may be more coherent. Harvey clearly feels that such a breaking-away can be achieved, ${ }^{103}$ and does so on the basis of his argument that:

Early Buddhism accepted a kind of spirit-like life-principle whose primary process is discernment. ${ }^{104}$ This life principle is not identical with the mortal body, nor wholly different from it; though it is 'supported' by and 'bound' to. It leaves at death. ${ }^{105}$

Such a principle is, by its very nature, surely an element of one's nāma existence. How are we to understand such claims though, in the light of previous statements, such as that of Nagāsena, that indicate the deeply intertwined nature of namma-rūpa? If we wish to maintain Harvey's claim that Buddhism avoids the dualism he describes (which is rather Cartesian in nature), can we allow for this rūpa-less nāma?

If we take a broad view of Buddhist thought, there may prove to be no reason why we cannot accept such matter-independent mentality. Buddhism has a more 
consciousness-populated view of the cosmos than contemporary reductive science. In a world-view containing 'formless states' as rebirth locations, a universe of devas and petas, a consciousness freed or temporarily separated from materiality seems less peculiar a notion. For example, when the types of becoming bhava - are enumerated in paticca-samuppāda analysis, we find three types of becoming. Appropriately enough, we can see this in the Sammā-ditthi Sutta:

There are, Sir, three types of becoming: becoming in the world of sensepleasures, becoming in the (realm of elemental) form, ${ }^{106}$ becoming in the (realm of) formlessness. ${ }^{107}$

This clearly indicates non-rūpa forms of bhava, and such an arūpabhava indicates that the relation of namma and rüpa that we are experiencing in our current lives is only conditional, and not necessary. This should not surprise us. While both namma and rüpa are both temporary collocations, there is no reason to believe that this indicates both stop and end together. Furthermore, if we take rebirth seriously we must surely presume some elements of nama to outlive the cessation of our rüpa states which takes place at the death of the body.

However, this does not necessarily indicate that $n \bar{a} m a$, or elements of it, are able to be free of rüpa in this world. ${ }^{108}$ In these other realms mentioned it seems wholly feasible, but there seems little to support such a notion as widespread in the Pali Canon. Perhaps the most convincing evidence for one who would argue for a this-world rūpa-less nāma is the powers of arahats. However, an arahat has a radically altered form of näma, and one may presume that they also have a drastically modified form of nāma-rūpa relationship. ${ }^{109}$

At this point I have begun to establish the Buddhist notion of the mind-body relationship as representing a holistic concept of the 'person'. A person is then made up of these mutually conditioning and deeply intertwined sets of processes. That said, how does such a view contribute to the current concern with desire?

Desire is surely primarily a näma phenomenon. But, as we have seen, it is so often a reaction to the rüpa, to the world of matter, most directly to vedana $\overline{\text {. We }}$ saw previously that desire is a response to 'feeling', which itself derives from 'contact', based on the 'six sense-bases'. What is intriguing here is whether this indicates that desire requires a rūpa basis. Were the analysis of the twelve nidanas to see only the five-senses as conditions for $\tanh \bar{a}$, then we could draw such a conclusion. However, Buddhism offers us six sense-bases. The non-physical one of these is mano - mind. We have seen mano already in this chapter, but I wish to return to it here to see how we can understand it in relation to the arising of desire-states.

Mind as a 'sense-door' has an odd ring to western ears. We can easily see the basis of sensory perception in the five senses of sight, smell, touch, hearing and taste; but mind? If we see nāma as non-physical, we might be tempted to think that we can treat mano as equivalent to the brain as a form of perception, the physical basis of mental states. This need not conflict with the view that certain 
specific states of 'mind' can exist independently of mano as brain. Such states would not be able to have any of the 'five-sense bases' as conditions, but may have as conditions mental events. Of course some of these mental states which act as conditions for non-rüpa-dependent mental states may themselves have an origination in a nama-rüpa interaction. But is this view of mano compatible with its usage in the Pali Canon?

Mano merits one of the longest entries in the PED, and from the primary definition of the term it is not clear that the aforementioned view of mano as the sense-response to the activity of the brain is going to be sustainable:

Mano represents the intellectual functioning of consciousness, while viñ̃āna represents the field of sense and sense-reaction ('perception'), and citta the subjective aspect of consciousness. ${ }^{110}$

Clearly perceptive acts occur within a specific element of consciousness, and leaving citta to deal with the subjective component does leave room for the interpretation I have offered of mano, but is this enough? If we do wish to continue viewing mano as the sensing of the phenomena produced by brain, then the rest of the PED view may be more supportive:

The rendering with 'mind' covers most of the connotation; sometimes it may be translated 'thought'. As 'mind' it embodies the rational faculty of man, which as the subjective side in our relation to the objective world, may be regarded as a special sense, acting on the world, a sense adapted to the rationality (reasonableness, dhamma) of the phenomena, as our eye is adapted to the visibility of the latter. Thus it ranges as the $6^{\text {th }}$ sense in the classification of the senses and their respective spheres. $^{111}$

If we do take this view, then all tanh $\bar{a}$ would seem to derive from a rūpa basis if mano has a rūpa rather than nàma basis.

We do not need, however, to adopt this position. Mano, as previously noted in this chapter, has a more complex role. If we see mano as, in part, the manager of the sensory process, we can avoid a simplistic view of it as 'brain' while retaining for sañ $\tilde{a}$ the role of sensory perception itself.

Another reason to reject the view of mano as 'brain' is that it is not seen as part of rüpa, the physical body. As Peter Harvey states, drawing on the Patthanna (1.5) and the Vibhanga (413) that:

Not only the physical basis of mind, but the mind itself is present from conception. ${ }^{112}$

This seems to undermine the possibility that mano is brain, as it would seem that mano can exist where there is, as yet, no brain. 
Where then does this leave us with regard to the overall position of the mind-body relationship, and the place of desire therein?

Desire here seems to arise as a response to the sensory process. We have seen this in relation to paticca-samuppāda. What has been gained through an examination of mind-body understandings is the way in which desire can be seen as mental in almost all aspects. Stimulation of desire may originate outside the person, but the desire itself arises as part of a set of mental causal processes. It seems unlikely that the physical alone can be a source of the arising of desire; desire is a mental response, based on a combination of perception, choice and other conditioning factors. ${ }^{113}$ If we are to intervene in the processes of desire, it is within the mind that such interventions are to be undertaken. This may seem an obvious conclusion, but it represents an important first stage in coming to the control and management of our desires.

Furthermore, we have begun to see the role desire has in the framing of our consciousness. This is a two-way process; for as desire contributes significantly to the way we view the world, our conscious (and sub-conscious) responses to sensory and mental events determine the nature and extent of any desire that occurs. We might, and this is partly why I now move on to look at the status of 'views', argue that craving-desires and ignorance of the way things really are (tanh $\bar{a}$ and $a v i j j \bar{a})$ are mutually reinforcing mental factors.

\section{The status of views: a structural analogy?}

Buddhism presents an interesting position with regard to the way it conceives its own teaching. One on hand, as we shall see, we are warned to be careful to avoid becoming 'attached' to specific views or doctrinal positions. On the other hand, we see Buddhism as a tradition deeply concerned with the clarification and articulation of its teachings. In D. J. Kalupahana's Buddhist Philosophy: A Historical Analysis he writes of the concern with and keenness for the clarification of Dhamma in early Buddhism. ${ }^{114}$ He may well be correct in attributing the fierce energy which seems to have been expended in scholastic activity and debate in early (and much later) Buddhism, to the Buddha's injunction that after his parinibbanna the Dhamma and the Vinaya were to be teachers of the Order. ${ }^{115}$ What, however, is undeniably striking is the Canonical concern with beliefs, often what we might term philosophical beliefs - both their nature and, significantly, their consequences.

Furthermore, we also see explicitly an understanding of Buddhism's own doctrines that sees them as, ultimately, something that will be no longer needed after enlightenment. We see this attitude most famously in the simile of the raft. We find this, besides cropping up elsewhere, ${ }^{116}$ in the Alagaddūpama Sutta. Here the Buddha explains that, as with a raft, the Dhamma is not to be held onto, or grasped at, once its purpose has been achieved:

In this way monks, I have shown you that the Dhamma is like a raft, for the purpose of crossing over, not for the purpose of grasping. ${ }^{117}$ 
This is reinforced in the Mahätanhāsankhaya Sutta where correct, accurate and spiritually useful views are also seen as a potential object of grasping, against which the Buddha warns:

'Monks, pure and cleansed as this view is, if you do not cling to it, have greed for it, treasure it, be attached to it, then have you understood that the Dhamma is like a raft, for the purpose of crossing over, not for the purpose of grasping?'

'Yes, Sir.' 118

Bhikkhu Bodhi summarises the Buddha's attitude to views when he writes:

The Buddha regards the adherence to views as part and parcel of the phenomenon of suffering, and in many suttas he has shown the problems to which such adherence can lead. ${ }^{119}$

While I shall return shortly to the precise nature and status of views, this does give us a sense of the extent to which doctrines and teaching are seen as functional or instrumental in the Pali Canon. ${ }^{120}$ Steven Collins applies this to both specific teachings and the overall way of life of a renunciant:

It is not only the conceptual formulations of doctrine which are thought to be potential objects of mistaken and harmful attachment. Both the general attitude of renunciation necessary for a monk, and the states of mind produced in him by the practice of Buddhist meditation, are only of value as instruments, and must not themselves replace nibbāna as the final goal. ${ }^{121}$

I will return to the specific issues shortly, but, you might ask, why, in a book concerning the status, nature and consequences of desire, am I addressing the same aspects of "views'? There are, as hinted at in the introduction to this chapter, a number of striking analogies between the treatment of desire and of views. Both are mental states with - at least most of the time - objects other than themselves.

Views, especially as referred to by the term ditthi, are potentially problematic and a spiritual hindrance in a manner strikingly close to that of desire. It is not just that incorrect or inaccurate views are likely to lead us into dukkha (which they clearly are, especially considering avijjā as the root nidāna in the formulae of paticca-samuppāda), but that there may be something problematic in-itself about the way in which we hold them. Attachment to views, ${ }^{122}$ even if they are potentially accurate ones, can be harmful and therefore considered as akusala in the same way that a grasping, $\tanh \bar{a}$-desire for a good or appropriate object of desire can also be potentially akusala.

To demonstrate this we can return to the twelve-fold paticca-samuppāda formula discussed previously. We saw that $\tanh \bar{a}$ was the $\operatorname{condition}^{123}$ for 
upādāna - which I translated there as 'attachment', but which might have equally well been rendered as 'grasping'. ${ }^{124}$ The texts indicate four classes of such grasping. These crop up at numerous points, such as in the Sangitti sutta, during the great list of the fours:

Four Graspings: at sense-pleasures, at views, at precepts and vows, at a Self-doctrine. ${ }^{125}$

He we see ditthi as an object of grasping, of attachment, and it is not in the best of company here. For example, attavāda is not a belief that is kusala-variable, but a harmful akusala mental state to possess. We can perhaps see this structural connection with desire here, as at times there are distinctions made between kusala and akusala views, and at other times views seem universally akusala. In a passage just preceding the one above from the Sangitti sutta we see views condemned again:

Four floods: ${ }^{126}$ of sense-pleasures, becoming, views, ignorance. ${ }^{127}$

Notably, Walshe renders ditthogo as '[wrong] views', 128 making a presumption that it is only inaccurate views that constitute an obstacle on the spiritual path. The four oghas here are identical with the four āsavas - cankers, or 'stains'. ${ }^{129}$ And at D.III.230 the four floods are also identical with the four 'attachments' upādānāni.

To continue this mirroring of desire, we also find the removal of views from our mental profiles as leading to nibbāna. At the end of the Cūlasinhanāda sutta, the ending of the four upādanas is examined, and the Buddha tells the monks:

Monks, when ignorance is abandoned, and knowledge ${ }^{130}$ arises in the monk, with the ending of ignorance and the arising of knowledge he clings neither to sense-pleasures, nor does he cling to views, nor to precepts and vows, nor to a Self-doctrine. Not clinging, he is not disturbed, ${ }^{131}$ not disturbed, he attains individually nibbāna. ${ }^{132} \mathrm{He}$ understands 'birth is ended, the Holy life has been lived, that to be done has been done, there is no further coming to this world' 133

There is a contrast here between salvific knowledge and ditthi. This could be read as an injunction to abandon views generally, but also might be seen as referring only to 'wrong-view'. Of course, there is also the notion of Sammāditthi - right-view - but we will come to this later in this chapter.

Dițthi is often viewed as being, on its own, 'wrong-view'. We find 'view', for example, condemned in the Abhidhamma literature. In the Abhidhammattha Sangaha, ditthi is listed as one of the fourteen akusala-cetasikas, or unskilful mental factors. ${ }^{134}$ Rewata Dhamma and Bhikkhu Bodhi translate ditthi here as 'wrong-view', and in their guide to the Abhidhammattha Sarigaha they offer the 
following analysis of ditthi as an akusala-cetasika:

Ditți here means seeing wrongly. Its characteristic is unwise (unjustified) interpretation of things. Its function is to preassume. It is manifested as a wrong interpretation or belief. Its proximate cause is unwillingness to see the noble ones (ariya), and so on. ${ }^{135}$

With regard to the use of ditthi, Carol Anderson claims that it is rarely used in a neutral sense:

Even when ditthi is used without the adjective 'right' or 'wrong', view connotes either right or wrong-views; very few passages offer a neutral interpretation of view. ${ }^{136}$

As we have seen, when ditthi alone is used it is commonly seen as 'wrong' view.

\section{The problem with views}

Views are not faring very well then, but why? What is so wrong with the holding of opinions? It may well relate to the consequences of their possession, in the context of the manner in which they are held. To make a judgment on this we shall have to see if there are views which are not akusala, and what prevents them from being so.

Indeed, we can quickly see that not all specific views are akusala. For example, in the Mahāparinibbāna sutta, the Buddha tells the monks of views leading towards nibbāna, that they should be: yāyam ditthi ariya niyyānik $\bar{a}^{137}$ - 'continuing in the noble view that leads to liberation'.

This is not an isolated case. Indeed the Noble Eightfold Path contains Sammāditthi, ('right-view'). This is encountered throughout the Canonical texts (e.g. at M.III.73). This is where we can begin to see why I have felt it necessary to examine the status of views. At times they do seem condemned outright, while elsewhere a distinction is made between right and wrong-views. This split between a total rejection and a kusala/akusala typology of views seems to mirror that done with regard to desire. Is a resolution of this tension possible? In order to answer this I need to further examine the nature of views and the reasons for attributing to them this important, if ambiguous, status.

Often ditthi seems to be assumed to refer to wrong-view - to micchā-ditthi - when only ditt thi itself is mentioned, as we saw above. Often it is left to the reader to determine from the context whether it is views in general or just wrong-views that are being condemned. In the analysis in the Canon of grasping, of upādanna, it is - as we might expect - broken down into various categories of grasping or attachment. In the Sammā-diț̣i Sutta (M.I.51) we find these enumerated again:

These are the four kinds of clinging: clinging to sensual pleasures, clinging to views, clinging to vows and precepts, and clinging to a doctrine of self. ${ }^{138}$ 
Here we see ditthi as an object of attachment that ought to be abandoned, and it is views in general which seem to be problematic. One might, however, see the use of ditthi here as shorthand for miccha-ditthi, for wrong-view. This does seem to be the approach taken, and indeed ditthi is referred to as 'esp. false theory' in the PED's definition of the term alone. ${ }^{139}$ The CSCD's PED (which is somewhat brief, but which also tends to represent common Canonical usage) gives ditthi as 'Sight, view, the eye; religious belief, doctrine; false doctrine, heresy'. ${ }^{140}$ We have the same problem elsewhere, such as when ditthi is considered as a 'canker'.

In Chapter 3, I mentioned the three 'cankers' (or as Walshe calls them 'the corruptions') - the āsavās However, at times a fourth $\bar{a} s a v \bar{a}$ is mentioned, that of ditthi. We can see this in the Mahāparinibbāna Sutta (D.II.81). Walshe offers the following translation:

The mind imbued with wisdom becomes completely free from the corruptions, that is, from the corruption of sensuality, of becoming, of false views and of ignorance. ${ }^{141}$

What is notable is that Walshe gives us 'false views', but the Pali reads only ditthāasavā. ${ }^{142}$ We can also see the $\bar{a} s a v \bar{a}$ of views in the Petakopadesa, where we find the common lists of wrong-view concerning the Self, culminating in the following phrase:

He who does not see 'I am this', his canker of views has come to be abandoned. ${ }^{143}$

We see here again the placing of views as negative - to be, like desire is so often cast, something to be overcome or abandoned. Overall there do, then, seem to be variations in the way views are handled in the Pali Canon. In some places there does seem to be this outright injunction to be free of them altogether. The sense of discomfort that one gets from the way views are discussed in the Canon, and the notion that we might be better off without them, derives from a concern of becoming attached to them. Rupert Gethin recognises this strand of thought in the texts:

in certain contexts what seems to be significant about ditthi is not so much the cognitive content of a view, but the fact that we cling to it as dogma, the fact that it becomes a fixed view: this alone is true, all else is foolishness. Thus even so-called 'right views' can be 'views' (ditthi) in so far as they can become fixed and the objects of attachment. ${ }^{144}$

Grace Burford recognises this concern with attachment to views, and identifies with a particular set of Canonical passages:

The specific condemnation of attachment to ditthis follows logically from the general condemnation of desire. The Atthakavagga argument against ditthis focuses on this type of attachment as particularly pervasive and 
dangerous. The issue is not whether one's particular view is true or false, but whether one is attached to any particular view. Presumably even if one were to discover a true ditthi (and this possibility is never explicitly ruled out in this text) aligning oneself with it, to the exclusion of conflicting views, would prevent one from attaining the ideal. ${ }^{145}$

The Atthakavagga is part of the Sutta-Nipāta, and is one of the most interesting sections of the Pali Canon with regard to views. This is most notable in the SuttaNipāta 786-7, where we find the following verses:

For the person with spiritual excellence, nowhere in the world does he have any mentally-constructed view about the various spheres of becoming. As he has eradicated delusion and deceit, in what manner can he be reckoned? He cannot be reckoned in any manner whatsoever.

He who is attached enters into debates about doctrines. By what and how can an unattached person be characterized? He has nothing to grasp or reject; he has purified all views here itself. ${ }^{146}$

Not long later in the Sutta-Nipāta we find a similar position, at verse 801:

For him [the Sage] there is no desire to strive for this or that, in this world or the next. He has ceased to associate with dogmas for he no longer requires the solace that dogmas offer. ${ }^{147}$

The problem in this second verse is not with ditthi but with 'dogma'. The Pali at the end of this verse - dhammesu niccheyya samuggahätam - seems to be along the lines of being free from the commonly understood/widely accepted teaching/view. It is this which H. Saddhatissa renders above as 'dogma'. While dhamma is the idea of a doctrine ${ }^{148}$ that one might be attached to, it is ditthi about dhamma (in the sense of 'doctrine') that is seen as something to be overcome.

Clearly the most intriguing line among those above refers to the notion of the one who has 'purified all views'. What can this mean? Is it akin to notions of the purification or transformation of desire? Is it a radically altered way of holding opinions that avoids the dangers of holding views in a dogmatic manner? I will return at a later stage to this notion of the 'purification' of ditthi.

For a summary of the problems with 'views', we can turn to Thanissaro Bhikkhu:

First the content of the view itself may not be conducive to the arising of discernment, and it may even have a pernicious moral effect on one's actions, leading to an unfavourable rebirth. ${ }^{149}$

This clearly applies to content-based problems with view - what are clearly 'wrong views'. Furthermore, my views and your views, like my desires and your 
desires, may be a source of conflict between us:

Secondly, apart from the actual content of the views, a person attached to views is bound to get into disputes with those who hold opposing views, resulting in unwholesome mental states for the winners as well as the losers. ${ }^{150}$

This makes sense, but the next problem that Thanissaro Bhikkhu gives us offers a slightly nuanced position:

Thirdly, and more profoundly, attachment to views implicitly involves attachment to a sense of 'superior' \& 'inferior', and to the criteria used in measuring and making such evaluations. ${ }^{151}$

Thanissaro Bhikkhu sees this as an important notion, and while not really mentioning the fuller problems of our 'attachment to views', this is a worthwhile point. He sees the holding of views as associated with a certain negative way of thinking - of placing categories on the world of experience. Clearly this derives from avijja , our ignorance of how things really are. He reinforces this when discussing the Aggivacchagotta Sutta and the Buddha's lack of views:

The construings the Buddha relinquished include views not only in their full-blown form as specific positions, but also in their rudimentary form as the categories $\&$ relationships that the mind reads into experience. ${ }^{152}$

The holding of views can be seen as the production of mental constructs, based on a specific avijja-conditioned way of engaging with the world and the results of the perceptual process.

\section{No-view or right-view?}

While the Canon is replete with passages warning us of the dangers of getting drawn into distracting and misleading metaphysical disputation, the passages recommending the eradication of views are relatively rare:

he [the Buddha] says that he does not dispute with the world; it is the world that disputes with him (Sn.III.138). It seems but a short step from here to the statement that he has no viewpoint (ditthi) at all; but this extreme position is found only, I believe, in one group of poems. ${ }^{153}$

Gombrich feels that a religion, especially one that wishes to proselytise, cannot do without debate. But is this the view of these poems? And even if it is, is this an abandonment of the possession of beliefs? Here we may have a twofold 
understanding. It is not just the content of views that matters - whether they are right or wrong-views - but the way in which they are held.

Gethin seems more assertive than Gombrich in claiming views to be something to be overcome or abandoned, albeit partly on the basis of the same Sutta-nipâta passages:

right view should not be understood as a view in itself, but as freedom from all views. This way of thinking is perhaps most clearly expressed in a series of poems found in the atthaka-vagga of the Suttanipäta, but is also implicit in the treatment of 'views' more generally in the Nikāyas. ${ }^{154}$

Steven Collins has no hesitancy in seeing that, in the end, views are to be left behind. While discussing views of the Self, he sees attachment to views as related closely to desire:

Views of self, then, are not merely castigated because they rest on supposedly untenable intellectual foundations; rather they are conceptual manifestations of desire and attachment, and as such need not so much philosophical refutation as a change of character in those who hold them. This change of character will issue ultimately in the attainment of enlightened status; the enlightened sage holds no views of self, as we shall see, because he is beyond conditioning. ${ }^{155}$

But how are we to respond - how do we abandon our attachment to views? Thanissaro Bhikkhu offers an insight into how this is to be achieved, how views are to be abandoned:

An important point to notice is that attachment to views must be abandoned through knowledge, and not through skepticism, agnosticism, ignorance, or a mindless openness to all views. ${ }^{156}$

The alternative to the possession of views in this negative manner is discussed shortly, but here we can see how not to abandon views. Just as tanhā is to be ended by understanding how it arises (and what it leads to), so with views our response should not be one of the unthinking reactions that Thanissaro Bhikkhu lists above, but rather one that seeks to see ditthi in the context of paticca-samuppāda.

This approach, of suggesting that we should not have views, has occasionally managed to exert a little influence beyond the borders of Buddhist thought. Indeed, the Theosophist writer Bas Rijken van Olst finds great inspiration in the aforementioned Sutta-nipāta verses, saying of them:

In this context, having no views is considered wise, for the sage that has reached a level of understanding where he knows that strife and dispute end once you stop being attached to this or that theory. These fragments 
from the Sutta-Nipāta breathe an atmosphere of tolerance and freedom from all doctrinal limitations. ${ }^{157}$

Inspirational as these verses may be, are we to take the view that van Olst develops in his article which seems to contrast intellectually held beliefs with the inexpressible knowledge of the mystic? While there may be a certain mileage to such an approach, even Sammā-ditthi seems to have a certain rational content - but it does raise an important issue. That is, is the difference between ditthi and Sammā-ditthi an epistemological one - are they different 'ways of knowing' - or perhaps - 'ways of seeking to know'?

One might suggest that the tendency to become attached to views is a form of Self-assertion, that it is a form of the atta-belief, for it can be seen as the 'I am right' or 'I know the truth, you don't' kind of attitude. This may pose a particular danger for the renunciant, who has committed his or her time to discovering 'the answers'. While the primary danger for the laity may be that of attachment to $k \bar{a} m a$, for the renunciant, ditthi may play a similar role, thereby reinforcing the link between views and desire.

Concern over the way of viewing - as much as the content of the view - makes sense in the context of what we can see as the overall approach to philosophical issues taken by the Buddha. Much of early Buddhist thought can be seen as a reaction to, and rejection of, the essentialist tendencies in Hinduism. As Gombrich claims, of the Buddha:

he was not an essentialist, and in contrast to the brahmins was interested in how things worked rather than in what they were. ${ }^{158}$

This approach is clear in the Canon - where the attention is repeatedly focused upon issues of process. In relation to desire then, no wonder it became - in Chapter 3 - such an entangled matter to define desire, for the concern in the texts is not so much on what desire $i s$, but rather on the role desire plays in the processes by which we come to suffer. Likewise with views, it may prove to be the case that it is, along with the correctness of a view, the manner of its possession that is vital to its kusala status. ${ }^{159}$ Indeed, were we here to return to the debates in the introduction, regarding the nature of the kusala/akusala judgement itself, we could argue that it is on the basis of the roles things play in the various processes leading to either dukkha or liberation that they are to be 'ethically' assessed. This surely supports the notion of kusala as skill - or skilful insight into the operation of reality.

\section{Sammā-dițhi - the nature of 'Right-View'}

Before moving on though, I wish to return to the notion of right and wrong-view. I do so with particular reference to Sammā-ditthi, because we can see in the texts a common strategy applied to this notion. This strategy is the way that the 
ethico-religious prescriptions of Buddhism are often to be understood in two ways - in a lower and higher way. ${ }^{160}$ This applies to Sammā-ditthi. We find this expressed in the Mahācattārīska Sutta (M.III.72), where all the Eightfold Path factors are given this bivalent treatment:

Right view, I say, is twofold: there is right view that is affected by taints, partaking of merit, ripening on the side of attachment; and there is right view that is noble, supramundane, a factor of the path. ${ }^{161}$

This is, as I say, a common strategy - to offer a mundane and supramundane version of kusala factors. The mundane tends to better rebirths, while the supramundane tends to liberation. The text offers further elaboration at this point, which primarily concerns the content of ordinary Sammā-ditthi, and is a little vague on the content of noble Sammā-ditthi, concentrating instead on the wisdom involved. ${ }^{162}$ However, as Rupert Gethin notes with reference to the Mahācattārīska Sutta (M.III.72) passage cited above:

The commentary explains that the former is concerned with ordinary insight (vipassana $)$, while the latter is concerned with the right view gained at the time of attaining the transcendent path. ${ }^{163}$

While his primary interest here is the extent to which Sammā-ditthi admits of degree (of different levels), it is tempting to speculate that the higher form of right-view may be likened to the transforming of the manner in which views are held, while the lower concerns the content of views. This is not explicitly supported, and therefore must stand only as tentative extrapolation. However, of the elements of the transcendent path, the attaining of the state of 'stream-enterer' is worth noting. The stream-enterer is not perfect, they are only part way (although quite a lot further than most of us, it has to be said) to liberation, but, as Gethin points out, ${ }^{164}$ certain negative cittas have been left behind by this point in their spiritual development, a number of them concerned with ditthi ${ }^{165}$ He goes on to make a revealing comment that begins to make me feel less guilty regarding the unsupported speculation above:

If we examine the Dhammasarigani description of each of the four transcendent paths, we find that the path of stream-attainment is described as 'for the sake of abandoning views' (dițthigatānam pahānaya). ${ }^{166}$

The other transcendent paths (of the once-returner, non-returner and the Arahat) concern the abandoning of desire, aversion, avijja and the like. This makes the notion of the noble form of Sammā-ditthi as not just the correcting of the content of ditthi but the altering of the way we view altogether, much more sustainable.

Returning to the previous notion of a 'purification' of ditthi, we do find an explicit term for such a thing in the last chapter of the Abhidhammattha Sangaha, 
where it - ditthivisuddhi - is defined as follows:

Purification of view is the discernment of mind and matter with respect to their characteristics, functions, manifestations, and proximate causes. ${ }^{167}$

However, this does not seem to contain any explicit notion of a specific reorientation of the manner of holding views, but rather seems to be another way of describing the content of Sammā-ditthi - through explaining that insight into paticca-samuppāda, primarily, is what constitutes a 'purified' view. Indeed, in the Rathavinita Sutta, we are told that this 'purification of view' is not the point of the spiritual quest (though of course it may prove a kusala aspect of moving towards this point):

'Now, friend, is it for the purification of view that one lives the holy life under the Blessed one?'

'Indeed not, friend.' 168

The Sutta goes on to state that the purpose of the holy life is the attainment of final nibbāna, while also - using the 'relay of chariots' simile - indicating that things such as the purification of view are needed to reach this final goal. At times, though, we do find purification of view associated with a kind of seeing that seems very far from most understandings of ditthi - certainly from wrong-view and ordinary right-view, and maybe even the more noble form of right-view. We can see this in the Patisambhidāmagga, in the phrase 'dassanațhena dițhivisuddhi abhiñ̃̃eyya,'169 'Through its meaning of seeing, purification of view is to be directly known.' 170 This is part of a long series of faculties and their meanings. Here it seems that the meaning of purification of view is to be known or understood through the idea of 'seeing'. This fits with the idea, that I shall address shortly, of supramundane Sammā-ditți as some type of 'direct seeing', rather than the holding of an accurate opinion.

There is also a discussion of purification of view in Buddhaghosa's treatment of the aggregates in the Vissuddhimagga. ${ }^{171}$ The discussion here follows the canonical linking of purification of view and purification of virtue $(s \bar{l} l a),{ }^{172}$ but expands and separates the detail, so that purification of view fits into a series of five purifications ${ }^{173}$ which form the 'trunk', following from two others:

the [first] two purifications, namely, purification of virtue and purification of consciousness, are its roots. ${ }^{174}$

Here we see an image of one's knowledge, for this is the context in this section of the Vissuddhimagga, as climbing up a tree - again a necessary step, but not one to become stuck upon. Indeed, we can see Sammā-ditthi as something which belongs not with the goal, but with the Path, as Bhikkhu Nāṇananda claims:

Thus the truth value of Dhamma - of Sammā Dițhi - pertains to the path, and it is essentially a view of the Goal and not the Goal itself. ${ }^{175}$ 
We see views, again, here as functional, as part of a process - but not to be taken as the purpose of the process itself.

Interestingly, Carol Anderson claims that there are three stages in the development of 'right-view', and it seems to be the first of these that is in addition to the two discussed above:

The first stage of right view is a general sense of affirmation toward the teachings of the Buddha (a pro-attitude) and the second stage is a greater familiarity with the tenets of Buddhist doctrine. At neither of these stages, nor at the third stage of liberating insight, should views be grasped or held. ${ }^{176}$

I have two points to make with regard to this. First, I am not sure that the general positive stance towards Buddhist teachings constitutes a 'view' in the sense that ditthi is used, other than maybe 'the view that Buddhism is a good thing'. Second, while it has become clear that one should not grasp views, can one 'have' a view without it being 'held'? I may be being pedantic here, but with at least reference to Anderson's middle stage, or what we might see as mundane Sammā-ditthi, it would seem that one is a holder of a view - the right-view. It is only when we attain the insight represented by the higher form of Sammā-ditthi that we cease to be a holder in this way.

Here we have seen the status of views, and there clearly seems to be something higher than ditthi, or at least there is this sense of a higher form thereof, in terms of understanding. This is some form of direct seeing, which does not rely upon the conscious adoption of specific doctrinal positions. ${ }^{177}$ One point where we do find an intriguing contrast between the direct seeing of the enlightened and the holding or possession of views is in the Aggivacchagotta Sutta (M.I.486). The Buddha is here being asked about his views by Vacchagotta (although in dialogue the Buddha seems to prefer the more familiar 'Vaccha'), and rejects a whole cartload of viewpoints suggested by Vaccha, many of them relating to areas of metaphysical speculation. A, no doubt rather frustrated, Vaccha finally asks the Buddha if he holds any view at all:

Then does Master Gotama hold any speculative view at all?

Vaccha, 'speculative view' is something that the Tathāgata has put away. For the Tathāgata, Vaccha, has seen this: 'such is material form, such is its origin'. 178

Here, as Nāṇamoli and Bodhi's notes point out, there is a nice play on words between the idea of 'views' and that of 'seeing':

In the Pali a word play is involved between ditthigata, 'speculative view', which the Tathāgata has put away, and dittha, what has been 'seen' by the Tathāgata with direct vision, namely the rise and fall of the five aggregates. ${ }^{179}$ 
As the PED notes, ${ }^{180}$ dittha is a term for that which is seen. This passage illustrates rather neatly the distinction I have been seeking to develop in this chapter. The dogmatic views that Vaccha offers are rejected not only on the basis of their inaccuracy, but also as they are of a class of citta, a kind of mental state, that an enlightened being has transcended in favour of this direct seeing. ${ }^{181}$

In order to extend this idea of the contrast between the possession of views and direct seeing, we can see views as being a way of perceiving the world that is mentally constructed. To see ditthi as mental constructs may seem an empty notion, adding little to what is said above, but to do so indicates that views are very different from the kind of direct seeing that the Buddha seems to prefer. To hold a view is to do something in addition to observing. Among other things it may be said to 'freeze' things - to have a view of something which is fixed, maybe take a snapshot of a moving image, and when we view the image, the thing it refers to has gone; making the picture inaccurate as a representation of how things are now. Given the dynamic nature of Buddhist thought with reference to paticcasamuppāda, this is an important point. To have a view is, as David Kalupahana points out when discussing the Buddhist philosophy of history, to evaluate - to make a specific judgement:

'Views' (ditthi), according to the Buddha, are products of human dispositions (saikkhata) or of intentions ( pakappita). Human dispositions are, for the most part, determined by excessive attachment ( $r \bar{a} g a$ ) or aversion ( dosa) or confusion (moha), while some are not so determined. Views, whether they be right $(\operatorname{samm} \bar{a})$ or wrong $(m i c c h \bar{a})$, are therefore evaluative in character. ${ }^{182}$

Here we can see that views are ways of constructing a mental landscape. To do so is dangerous as such constructions tend to arise conditioned by - as pointed out above specifically - rāga, dosa, and moha, and more generally by avijjā. Even right-views can be seen as evaluative, that is they make judgements. ${ }^{183}$ However, we should perhaps be wary of following this line too far. Buddhism does make judgements, and openly. Distinctions between kusala and akusala acts are important, and I feel that the position of views is not so extreme as to prevent this. Another way to describe the concern with views is that many speculative views are, by their nature, partial. That is, by taking a certain stance, we close off other aspects of reality. In this context, it is not all evaluations that must be abandoned, but a certain way of evaluating - we must avoid using our views to narrow our perspective and close our minds to other possibilities.

The deeper sense of right-view, then, might be best seen as distinct from conventional right-view in its refusal to enter into such closure-seeking. This surely adds strength to the notion of right-view in its deeper sense as direct seeing, as opposed to purely holding accurate rather than inaccurate opinions. We might associate noble right-view more with wisdom than the seeking of accurate knowledge, and this fits with many of the concerns over the ways views and 
beliefs are treated. As Hoffman writes:

Unlike knowledge, wisdom is thus necessarily spared the indignity of becoming a commodity. ${ }^{184}$

While he is not talking explicitly of ditthi here, the point sticks. Ditțhi are all too easily treated as a commodity. Noble right-view can be seen as more open and dynamic than the stasis-seeking closure of micha-ditthi and even lower Sammā-ditthi.

We can find this further strengthened when we see another account of the Buddha's discussion with Vacchagotta. In the Vacchagottasamyutta ${ }^{185}$ we find a topic similar to the account of the discussion with Vaccha above, but here the possession of the speculative views the Buddha will have nothing to do with is contrasted more widely. Here the contrast is with more than just 'seeing' the truths of Buddhist teaching. It is here said that various failures of insight lead to the situation whereby 'those speculative views arise in the world'. ${ }^{186}$ These views arise due to the factors listed here:

Because of Not Knowing; Because of Not Seeing; Because of Not Breaking Through; Because of Not Comprehending; Because of Not Penetrating; Because of Not Discerning; Because of Not Discriminating; Because of Not Differentiating; Because of Not Examining; Because of Not Closely Examining; Because of Not Directly Cognizing. ${ }^{187}$

This is intriguing. The speculative views are based on a lack of certain competencies. Some fit well with the position I have been outlining here, such as 'seeing' and 'directly cognizing', but others require some comment. In the view that Samma -ditthi, in the more noble sense, is a direct seeing, what are we to make of components such as 'discerning', 'discriminating' and 'differentiation'? These seem like just the kind of mental manipulations of experience that are so problematic in the discussion of Kalupahana's position above. One can only presume that all perceiving of the world by an individual requires these elements of the perceptual process.

While this is not the place to enter into a detailed discussion of the process as seen in Abhidhamma texts, perhaps we can come to the view that all views samma $\bar{a}$ or micch $\bar{a}$ - have to be initially based on what we can discover of the world through the process of sensory perception.

Perhaps we can come to the view that while we have to make distinctions, the Suttas are full of them. We should keep in mind not only the need to avoid being attached to these distinctions, but also that those things which we separate by making distinctions are, at the same time, linked - through conditions, through pațicca-samuppāda. We need to be able to see differences and distinctions within the fluid, dynamic world, without freezing these evaluations into separate substances or isolated entities - it is into the latter trap that views so often fall. 


\section{A paradox of views?}

Before moving on to look at the connection between desire and views in detail, I wish to examine a claim that we can see in the Buddhist treatment of views a 'paradox of ditthi', equivalent to the paradox of desire discussed in the Introduction. This follows from my discussion above on whether no-view is equivalent to right-view, and is proposed by Grace Burford in her Desire, Death and Goodness.

Burford identifies the Atthakavagga section of the Sutta-Nipāta as putting forward the idea of 'no-view' as an ideal, but sees this as potentially problematic:

The view of no-views is a teaching of non-duality. As such, it cannot explicitly deny the validity of views that deny the validity of other views, without undermining its own authority.

This paradox brings to mind another that is raised by the Buddhist teachings: The paradox of desire. ${ }^{188}$

Here we see the crux of her concerns with this teaching of 'no-views'. Burford takes on the connection with desire to claim that the discussions around views reflect a deeper problem with the understanding of desire:

By extending the objects of desire to include views, the author(s) of this teaching ${ }^{189}$ eventually forces the issue of the paradox of desire. By shifting the focus away from desire for wealth and existence, toward attachment to views, the author(s) brings out the less obvious (and there- fore eventually even more troublesome ${ }^{190}$ ) inconsistency of the teaching that identifies desire as the problem and then fails to show how desire to end desire is different from any other sort of desire. One cannot ignore the ease with which the anti-views argument is developed here: from that first premise that desire is the root of all evil comes the argument that preference for any particular view, path, and even goal is counter-productive on the path to the ideal. ${ }^{191}$

A number of points here need engaging with. First, I feel I have begun to show that Buddhism does identify what makes kusala desire distinct from akusala desire. As I have argued, this is not only through desire's object (or Burford would be wholly right here), but also through the nature of the desire - the manner of wanting. Second, we can extend this to our understanding of views.

The promotion of no-views as an ideal in the Atthakavagga may initially seem at odds with the promotion of Sammā-ditthi elsewhere in the Canon, but this is, I think, a matter of two ways of describing the same thing. Supramundane Sammā-ditthi can be seen as right in the sense of being the attitude to views that one should take, but also as no-view as it is a radical reorientation in our manner of viewing. We may still, once in possession of this higher right-view, be able to evaluate the varying qualities of content-based ditțis. 
To possess no-views is to be unattached to any views, to see and not grasp. Just as desirelessness does not prevent us from having a hierarchical kusala-based assessment of desires, so having no-views does not prevent us seeing the relative merits and dangers in specific ditthis held by others. This represents an important way of overcoming these notions of paradox.

\section{Desire and views: craving and ignorance}

Having examined Burford's claims regarding the connections between desire and views, I now return fully to the issue of desire. In returning to desire, I wish to demonstrate how it connects to the notion of ditthi. To do this we can turn to the two most central doctrinal formulae of Pali Buddhist thought: the Four Noble Truths and the teaching of paticca-samuppāda - Conditioned Arising. Both identify what they see as the root or base cause of $d u k k h a-$ of the unsatisfactory nature of the world, or more accurately our lived experience of the world. The Truths implicate tanh $\bar{a}$, while we find that the twelve-fold formula of paticcasamuppāda lays much of the blame at the door of avijja .

Some might see a potential problem here - a tension based on a chicken-andegg-like 'which came first?', 'which is the worst/true cause of suffering?' set of questions. Such questions not only presume the kind of linear cosmology that has little relevance here, but also presume the necessity of a cosmogony that will explain them. We see the two, ignorance and craving, together at S.II.24:

Bhikkhus, for the fool, hindered by ignorance and fettered by craving, this body has thereby originated. ${ }^{192}$

Which seems primary or foremost depends on how you look at the processes involved. The Avijjā Sutta (A.V.113f) seems to treat them as of equal value, and while both are seen here as being without a first instance, they are excluded from acting as metaphysical principles by being seen as arising in specific instances, and having nutriments - āhäras. For ignorance, we find, is nourished by the Five Hindrances, ${ }^{193}$ while the next sutta, the Tanhā Sutta, identifies the nutriment of bhava-tanh $\bar{a}$ as avijja. ${ }^{194}$

This is interesting for two reasons. First, it seems that ignorance is being seen as more primary than tanh $\bar{a}$, but this is complicated by the presence of a form of desire as the first hindrance. Therefore we can see ignorance and desire, albeit in various forms, as mutually conditioning. Second, here bhava-tanhā is treated in a way that is similar to the approach of Robert Morrison, seeming to see it as the primary form of tanh $\bar{a}$. However, here tanh $\bar{a}$ is being discussed in the context of first causes, ${ }^{195}$ of an original arising, so we should perhaps not be too surprised to find bhava-tanhā as most central in this specific context.

As a final point on tanh $\bar{a}$ and avijja as the central problems in human life, and obstacles to spiritual progress, we find two passages in the Itivuttaka which demonstrate this clearly. Suttas 14 and 15 are named the Avijjānīvaranasuttam 
and Tanhāsamyojanasuttam respectively. The former opens with the following claim about avijjā:

Bhikkhus, I do not perceive any single hindrance other than the hindrance of ignorance by which humankind is so obstructed and for so long a time runs on and wanders in samsāra. ${ }^{196}$

The following Sutta opens with an almost identical claim about the nature and effects of tanhā:

Bhikkhus, I do not perceive any single fetter other than the fetter of craving by which beings are so tied and for so long a time run on and wander in samsāra. ${ }^{197}$

This may seem contradictory, but in the context of what has been said above, and in the light of paticca-samuppāda, these twin claims do make sense. In coming to this understanding of how the two are equally problematic, we need to see them as linked. The medium by which we can seem them as yoked together is ditthi.

In seeking to understand the relations between avijj $\bar{a}$ and tanh $\bar{a}$, ditthi is a valuable, indeed vital, notion for it serves as a conceptual bridge between these ideas. Gethin also casts ditthi in much the same role:

this is precisely where the notion of ditthi comes in, for it combines both the root causes of suffering: ignorance and greed. ${ }^{198}$

This is an important idea, and one that ties together much of what I have been driving at in this chapter. Micchä-ditthi is a representation of both craving or grasping and ignorance at the same time. In both the senses of ditthi here - of wrong content (ignorance) and the wrong means of believing (grasping/craving) we see revealed the interconnectedness of these causes of dukkha. However, when 'viewing' is done not in the sense of a form of upādāna, but as noble Sammāditthi, it ceases to be the holding of an opinion or belief. What is represented by Sammā-ditthi is, particularly with reference to its more noble form, a direct seeing - an, if you will permit, insight. As Gethin suggests:

Rather than the occurrence of a mere belief or opinion in the flow of mental states, sammā-ditthi is presented in the Abhidhamma as in some manner as always be [sic] a direct seeing of the four truths, and never simply a 'pro-attitude' towards or belief in, say, the four truths. ${ }^{199}$

Now, we might take these comments to indicate an epistemological distinction. The phrases 'pro-attitude' and 'belief in' seem all too ready to be contrasted with a notion of Sammā-ditthi as 'knowledge'. We need not be so tentative though, despite the contemporary reticence often exhibited towards 'knowledge-claims'. 
If we take seriously the words of the Buddha in the Kàläma sutta, then direct seeing via personal experience is the only means to knowledge - for the replacing of speculative assertion and dogmatic grasping with a seeing which almost fulfils the Western philosopher's triple-criteria of 'Justified True Belief'. Only on the last one might there be some niggling as to whether this direct awareness qualifies as belief, and given the consequences of such attainment - a movement towards liberation from all suffering - getting drawn into such a debate begins to look just like the kind of disputation we have here seen so many warnings against.

\section{Reason and desire revisited}

In the first chapter we saw an important opposition established between desire and reason. From the Greeks onward we saw the two as in tension - one followed the heart (desire) or the head (reason); this is a common image in Western thought, both in philosophy and common usage. Having seen how Buddhism views desire, might we be tempted to suggest that it has a greater liking for an approach dominated by rationality?

While I do not wish, at this stage, to become embroiled in a debate on the nature and status of reason in Buddhist thought, this is an issue worth considering for two reasons. First, as stated, there is this common opposing of desire with reason as its other. Second, there is something in the Pali usage that has interesting similarities with the structure of representation already seen between desires and views.

On one level we can see this heart/heard distinction found in Western thought as represented in Buddhist practice by the need to balance the faculties of faith and wisdom. This may go some way to representing the Buddhist view, but given the analytical nature of much Buddhist work, what of reason - is wisdom reliant on rationality?

The key Pali term in this context is takka. This is a term that does not seem to be regarded as the highest activity of the human - as Aristotle might be seen to view reason. ${ }^{200}$ Indeed, the PED starts off its definitions of takka on a fairly negative note: 'doubt; a doubtful view ... hair-splitting, reasoning, sophistry'. ${ }^{201}$ The PED equates it with ditthi, and we can see the connection. In its usage it can often be seen as a negative form of reasoning - an excessive tangling of thought. We can see this to an extent in the Kālàma Sutta at A.I.189. ${ }^{202}$

In this famous sutta, the Buddha tells the Kälämas, confused as they are by the preponderance of teachers with their various competing theories and doctrines, about the way to judge between the teachings of those samana brāhmanā kesamuttam ägacchanti ${ }^{203}$ - the renunciants and Brahmins who come to Kesamutta. The Buddha lists various aspects of a teacher or teaching which are not to be taken as a sign of its reliability, most importantly its efficacy. ${ }^{204}$ In his view, we are told that we should go:

Not by reports, by lineage, (oral) tradition, collected scriptures, logical reasoning, inferential reasoning, by the result of reflection, by the appearance of a view, by what seems possible, by the importance of a teacher. ${ }^{205}$ 
This passage is often used to claim that the Buddha wished his followers to test his teachings themselves, and can be seen as the basis for the view that Buddhist philosophy can be tested in some empiricist sense. ${ }^{206} \mathrm{I}$, however, do not wish to be drawn too far into these matters at this stage. Rather I wish to demonstrate that we might see 'reason' as something potentially negative in a Buddhist context. At least here it is seen as insufficient, it seems, to use reason alone to validate a spiritual perspective - some form of empirical (or maybe supra-empirical) validation is also required/available. Kalupahana argues that there was, at the time of the Buddha, already some concern over the use of reason:

Moreover, as is evident from texts like the Käläma-sutta, people had already begun to suspect the validity of reasoning (takka) and logic (naya) as means of arriving at a knowledge of truth and reality. ${ }^{207}$

We can see takka also as something to be overcome, as in the Muni Sutta, where the one who has attained the goal is said to have 'overcome sophistry [takka]'. ${ }^{208}$ Saddhatissa's translation here sees takka as 'sophistry', marking a clear view of the nature of takka in this context. ${ }^{209}$

But early Buddhism is clearly not intentionally irrationalist. ${ }^{210}$ It is often deeply analytic, ${ }^{211}$ so might we then think that it also has a more positive view of rationality and reasoning? As yet, we have seen no general invective against reason per se; rather it seems that the over-reliance on it, or the use of a certain type of it, is where the problem lies.

To consider 'reason' more fully, another term requires attention: vìmams $\bar{a}$. The PED gives a limited meaning, rendering it as 'consideration, examination, test, investigation'. ${ }^{212}$ While this is interesting - and vimmam sa $\bar{a}$ is much more positive, being part of one of the four iddhipādas - it has moved us away from 'reason' in the sense of logic, or as opposed to emotion. I include it though, with the intention of indicating that Buddhism does favour thorough investigation and study of phenomena. $^{213}$

To build up a full picture of the attitude to 'reason' in Buddhist thought, I would, at least, need to engage in a study rather like that of Chapter 3, but will limit myself here to some key terms. ${ }^{214}$

Many of the terms translated, in some sense, as 'reason', actually indicate 'reason' in the sense of cause, or condition. For example, most uses of the term hetu are very close in meaning to paccaya. ${ }^{215}$ We can also find sañcetana, which is more along the lines of 'thinking'. The PED gives it as 'animate, conscious, rational', ${ }^{216}$ and it seems to just reflect the ability of a being to think or be conscious. $^{217}$

At this stage it is also worth mentioning dhamma-vicaya. This is listed as one of the seven 'Factors of Awakening'. ${ }^{218}$ But what does 'dhamma-vicaya' mean? In his translation of the Sampasādaniya Sutta, at D.III.106, Walshe opts for 'investigation of states'. ${ }^{219}$ This seems reasonable enough, but gives little sense of what it might involve. Is this meditational introspection, rational reflection, or 
something else? Rupert Gethin offers an etymological breakdown of the term, before coming to his conclusion:

So dhamma-vicaya would mean the 'taking apart of dhamma'. In Buddhist thought to take dhamma apart is, I think, to be left with dhammas. Dhamma-vicaya means, then, either the 'discrimination of dhammas' or the 'discernment of dhamma'; to discriminate dhammas is precisely to discern dhamma. ${ }^{220}$

This is interesting - for here, by coming to see the dhammas, we come to see Dhamma in the broad sense. This process of discernment, and one involving discrimination of states, is useful. It demonstrates the central importance in coming to discern Dhamma, in coming to see the way things are, of discriminating. Here we can see that rather than being abandoned as a spiritual hindrance, making assessments and drawing distinctions is a vital component of the Path. It is the manner in which we do so, where we can take a kusala or akusala approach - of course - with regard to the actual discriminations we make. This should help deepen not only our sense of how reason operates, but also how views are to be seen in general.

Overall, Buddhism seems a little suspicious of reason alone - reason as purely logical investigation. What seems to be the case is that what Buddhism does favour sits somewhere between the two Western epistemological approaches of empiricism and rationalism. Buddhism prescribes meditation; and this process requires clear thought and investigation, but is not a process that can be purely described as 'reasoning' - it is clearly more experiential, hence the nod towards something akin to empiricism. This topic is picked up again in the next, concluding chapter.

\section{Conclusion}

It may seem as if this chapter has roamed somewhat, but what I have sought to do here is to place the Buddhist notion of desire in context. By understanding where and how desire occurs we have seen it as a process, and have been able to view that process in action.

Furthermore, a key idea that has arisen in the course of this chapter has been the connections between desire and cognitive-states, particularly views and knowledge. This has been in a number of different ways. First, there is the notion that both ditthi and tanha are to be overcome, transcended and abandoned in order to attain the final goal of nibbāna.

We have also seen, however, that knowledge - to be distinguished at times from ditthi $i^{221}$ - is often seen as salvific. In the supra-mundane noble path, we can find two additional path-factors; sammā-ñànam (right-knowledge) and sammā-vimutti (right-liberation). As we find in the Janavasabha Sutta, ${ }^{222}$ the former of the pair is seen as leading to the latter - knowledge leading to liberation. 
We also, in the Suttas, see the term ñanna-dassana. These two terms, individually, mean 'knowledge' and 'seeing' - but how to read their compound use? The PED seems ( p. 287) to treat them as a $d v a n d a$ compound, ${ }^{223}$ as does the translation of the Mahāsāropama Sutta in $\mathrm{MLD}^{224}$ where the term is rendered as 'knowledge and vision'. Interestingly though, the CSCD dictionary treats the compound as a tappurisa type, ${ }^{225}$ defining ñana-dassana as 'insight given by knowledge'. Either way, and I am more persuaded by the first approach to the term here, we can see that knowledge is a vital aspect of achieving the Buddhist goal.

However, at times we might be tempted to suggest that it is the absence of ignorance (avijjā, often given as equivalent with nibbāna) rather than the presence of knowledge, which is important. Why is so much of the suttas devoted to overcoming avijjā ? Why not just promote the development of knowledge? One might see this as an intentional and pragmatic form of rhetorical strategy. By concentrating on the overcoming of avijjāa, Buddhism may be seen as seeking to avoid presenting knowledge in such a way as it becomes an object of desire and grasping - of ditthi. ${ }^{226}$

The second connection between desire and avijj $\bar{a}^{227}$ was that they can be jointly seen as the primary, if not exclusive, roots of $d u k k h a$, and indeed of being. It is our misperception of the nature of reality that leads us to desire in unrealistic and harmful ways - we believe that we can find permanent objects of desire that will bring us permanent happiness. At the same time, our desires are such that they blind us to the true nature of things, distracting us from taking the time to assess the true nature of things as we rush heedlessly after fleeting objects. ${ }^{228}$

Perhaps it is best to allow the last word on the topic of views to the Canon, where we find a kind of direct seeing extolled as the correct approach for the spiritual aspirant:

Bhikkhus, held back by two kinds of views, some devas and human beings hold back and some overreach; and those with vision see. ${ }^{229}$

So, how are we, overall, to view the arising of desire states? The only types of desire that the paticca-samuppāda formula deals with explicitly are tanhā and upādāna, but many of the others are likely to arise in similar ways. What is fairly clear from what we have seen in this chapter is that desire consists of more than a straightforward attraction-repulsion response to an object of perception. Desire does consist of a subject-object relationship - or at least is experienced in such a manner, particularly by those in possession of atta-ditthi - but there is more to it than this. As we have seen, a significant number of conditioning factors come into play during the process. One's level of ignorance is a factor, as is sañña , but a factor I have commented upon little, although implied by some of the others, is the level of calm or disturbance within one's consciousness. An agitated consciousness is more likely to respond in the attractor-repulsor manner mentioned above, while a calmed, stilled mind is more capable of reflection and consideration of sensory stimulation and feeling, limiting the potential for non-mindful psychological responses. 
At the outset of this chapter, I suggested that desire was viewed in Buddhism as something in need of refining, and that this is the process that can lead to the transcending of desire. Is this still tenable? It would seem to be a position that has survived what has been said here, concerning paticca-samuppāda, relatively unscathed. While the need to transcend desire has, if anything, been reinforced, the possibilities and process for refining desire have been clarified. An important corollary has been the notion that this is inextricably linked with the transcending of views, and we have seen the explicit enumeration of a process that leads from miccha-ditthi to two qualitatively distinct forms of Sammā-ditthi, to a final direct seeing.

Any understanding of the nature of desire in Buddhism has to be seen in the context of views, and the process of refining and transcending of desires and views is something of a process that is more than parallel, but of necessity intertwined and mutually supporting.

It is worth, at this point also noting that the way desire is seen as something to be gradually refined and overcome can also apply to views. We can see this in the move from wrong-views to ordinary right-view, to noble right-view. A streamenterer has overcome sakkāya-dițthi, ${ }^{230}$ but still may possess $k \bar{a} m a$; a non-returner has no kāma, but still has rāga for the rüpa and arüpa levels of existence, along with some aspect of avijjā; and an Arahat has overcome all these and attained the goal. ${ }^{231}$

A number of other issues have come up during this chapter, but as I wish to relate many of them to the conclusions from Chapter 3, I leave them for the next, concluding chapter. 


\section{CONCLUSION}

\section{Desire and the transformation of living}

That Bhikkhu who has crossed over the swamp,

Crushed the thorn of sensual desire,

Having arrived at the destruction of delusion, Is not disturbed by pleasures and pains. ${ }^{1}$

As soon as you stop wanting something you get it. I've found that to be absolutely axiomatic. ${ }^{2}$

\section{Introduction}

We have seen desire from many sides now. But, do we understand desire at all? The experiential quality of desire is a yearning or hankering that, in spite of the preceding chapters, seems to slip away from the net of language. Perhaps the best we can do is to gain an insight into how it arises, its consequences and use this as a means of intervening in these processes to better manage it.

What I offer in this chapter is an attempt to harness the thought of Western and Indian thinkers to try to give us a further insight into the Pali Buddhist understanding of desire. I do this in order to demonstrate the ways in which the Buddhist approach can be seen to contain shadows and echoes of these other traditions. In doing so, I seek to demonstrate the extent to which the Buddhist view is an attempt to offer a comprehensive therapeutic response to our desiring.

In order to achieve this, I begin by summarising the previous positions we have seen, and follow this by examining a number of key themes which have emerged in these chapters. Finally I outline the way I see desire in Buddhism. In this view, I claim that Pali Buddhist thought on desire offers us a uniquely nuanced analysis.

Furthermore, I hope to establish that this view goes far beyond the merely analytic or academic; indeed it may offer us a path of calm that leads away from the tumult of wanting towards a new kind of life. This flight from desire - the great upsetter - is not a flight from life, or from choice or aspiration, but rather a fleeing from the wanton wanting that threatens to enslave us. Freedom from desire is indeed a great liberation, for it allows us to choose and act in ways not predicated 
on either metaphysical illusions or a desperate hankering after kinds of fulfilment that will always lie beyond our reach. ${ }^{3}$

\section{Western perspectives}

Desire, then, appears as a gap, a discrepancy, an absent signifier. ${ }^{4}$

In the first chapter we saw a broad range of views. Some key themes did emerge from this though. Most clearly we saw many seeking to define desire in terms of 'lack' or 'absence'. Here the nature of desire is understood in terms of the object of desire - it sees desire as consciousness of absence. Clearly not all awareness of absence is the same as desire. I currently know ${ }^{5}$ that I do not have an elephant's trunk protruding from my forehead - I lack this. Oddly enough though, I have no desire for such a protuberance.

Desire then is something more than just lack, or consciousness of absence. It is a positive, intentional mental state inclined at the possession of something one lacks. We might also wish to consider its negative form: intentional states inclined at the non-possession of something we possess or might possess ${ }^{6}$ - this is the desire to negate, aversion. We might see aversion as the mirror image of desire, for what is aversion but a desire to avoid - a desire writ in negative? As such, much of what has been said here can be seen to apply to states of aversion as well as of attraction.

The Western thinking on desire as absence or deficiency was far from consistent though. At the most straightforward level we saw the view that we can only desire that which we do not possess, ${ }^{7}$ but elsewhere we found desire placed at the heart of a metaphysical discourse. The insatiable nature of desire - the lack of fulfilment that it represents - was, most particularly by Sartre, associated with a lack of a fundamental nature. This lack can be understood as 'nothingness', as absence of being. The relation between the notions of desire and absence will be examined later in this conclusion.

The powerful ideas of desire as creative and powerful - so to the fore in much Hindu thought - were, for much of the material we saw in Chapter 1, strangely absent. It was only in nineteenth- and twentieth-century thought that we see such notions emerging with any forcefulness. Even when these ideas do so, they are far from clear. For Nietzsche they are clothed in notions of 'Will', and for writers like Deleuze we find them enmeshed in complex socio-political discourse.

The most prominent contemporary writer on desire, Judith Butler, steeped in the approach of Hegelian metaphysics and the contemporary French style of doing philosophy, has much to say. However, much of it is relevant only to the internal debates of post-Hegelianism. What she does articulate thoroughly though is the understanding of desire as closely linked to the notion of bodies. In her conclusion she goes as far as to state:

desire will be understood in the context of the interrelationship between historically specific bodies. ${ }^{8}$ 
And she goes on to suggest that "the "truth" of desire may well lie in a history of bodies as yet unwritten' ${ }^{9}$ This ties desire closely with embodied existence. Like so much later Western thought, desire is a regulator and instrument of the relations of humans as beings whose bodies dictate to, as much as they are dictated by, the nature of consciousness. The inner discourse that desire provides is one of its own creation; it creates worlds of thought that negate. They negate the present with as-yet-unrealised possibilities. It is this type of approach that seems to lead Butler to the final comments of her influential book:

From Hegel through Foucault, it appears that desire makes us into strangely fictive beings. And the laugh of recognition appears to be the occasion of insight. ${ }^{10}$

How are we made fictive through desire? In one sense it can be linked to the notion, found in Sartre, of negation. By negating the present we can conceive of things being other than they are. By the possession of desire, we visualise a world other than it currently is - a world in which we possess something we now lack; or, to avoid the use of this notion of lack, a world which is differently ordered. Desire is fictive for it is an imaginer of the non-factual, the could-be and wished-for.

I must admit though that I am unsure how to understand quite what she is laughing at in the above quote. Perhaps when we recognise how we have been seeking via visualisation, we come to see our desiring, to use existentialist terminology, as absurd - and this insight prompts a 'laugh of recognition'.

Another key theme in the Western material surveyed was one that matches more explicitly with the Hindu and Buddhist approaches - at least on the surface. We did encounter, in the first chapter, desire regularly cast in a negative moral role. Desire is what confounds our reasoning, what drives us to rash acts, to abandon our moral sensibilities and can be seen as the core of selfish actions. This found its culmination in Schopenhauer's notion of the Will, a notion of human enslavement that sees this force as the creator of human life as misery and toil. Of course, this was not an undisputed discourse.

In Hume's admirable scepticism and Nietzsche's joyous affirmation, we find dissenters. One does not have to be a paid-up Freudian to recognise the significance of this approach - an approach that resists the vilification of desire and seems to offer a more fully rounded conception of the human. These dissenters refuse to be drawn in by the bi-polar demarcation between the higher life of the rational and the body-led world of desire. As we saw in Chapter 4, Buddhism also resists this Cartesian-Platonic approach to desire in the mind-body nexus.

Overall, my examination of the Western approach was revealing. Not only for what was said, but that much of what was written stood almost in the margins. Desire has never been the central topic in Western philosophy, and from this one might draw the conclusion that desire is not wholly seen as an appropriate object for philosophical enquiry. This may indicate the non-introspective tone that much Western metaphysical thought maintains. Indeed, we only find desire examined in 
a more thorough and explicit manner once traditional Western approaches, particularly to ontology, began to be questioned and undermined in the nineteenth and twentieth centuries.

\section{Brahmanic views: desire and ontological necessity}

Not surely does the wind equal Kāma, not the fire, not the sun, and not the moon. To these art thou superior, and ever great; to thee, O Kāma, do I verily offer reverence.

With those auspicious and gracious forms of thine, O Kāma, through which what thou wilst becometh real, with these do thou enter into us, and elsewhere send the evil thoughts. ${ }^{11}$

From the outset, Hindu thought wrestles with desire. The very origins of the universe lie tangled with desire. While taken as a whole Hindu thought might seem ambivalent to desire, we might better describe it as multivalent. We see desire operating on numerous levels, from the cosmological to the ethical.

At the heart of all these seems to lie a common conception though: desire is powerful. Indeed, I would suggest that it is from this notion that the ethical ambivalence regarding desire flows. Desire can only be safely wielded by the competent. In the hands of the ignorant and greedy, it is a danger. Its ability to act as a creative force is what lies at the root of its power. By wanting we make realities. In a sense, the wanting of the ignorant might be seen as the tool by which $m \bar{a} y \bar{a}$ is crafted. From this recognition pour forth the perspectives on desire we witnessed in Chapter 2.

I am tempted to suggest that when we compare Western and Hindu concepts of desire, there is a striking inverted symmetry between the two. We could argue that Hinduism starts out, in its earliest origins, with desire as power - a potentially dangerous (and often externalised) force of huge creative power and importance. But as it moves on, it views desire as something we are better off without - or that our desires should face only God/Self-ward. This inverse symmetry might be established by arguing that the Western approach has moved from a view of desire as lack to a view of desire as powerful and creative.

Such a rhetorical strategy just will not do, however. Why not? It looks quite neat and has a certain satisfying closure about it. The problem lies with the complexity of both views. The Hindu view saw the dangers in desire from the outset, and throughout Western thought the role of desire has been polyvalent and polymorphous. The role of desire, in both traditions, is too wide for such a trite, albeit neat, piece of theorising.

If we abandon this attempt to demonstrate a neat symmetry between Western and Hindu approaches to desire, what do I mean by the term in the title of this section 'ontological necessity'? By this I seek to indicate the extent to which desire precedes being. Desire can be seen in Hindu thought, in a way reminiscent of certain other well-known descriptions, as creator of the world, and its sustainer. ${ }^{12}$ 
Can we even go as far as to liken desire to the fabric of the universe itself? If we look at the hymn to Käma that opens this section, then it would seem so. Beyond this though, we have seen how fundamental desire is in Hinduism. It is so basic to existence that to discuss it always draws us back to ultimate and difficult questions - this is perhaps the source of its ethical ambivalence. If the entire fabric of the universe is not actually wholly woven from the threads of desire, surely at least we can see desire as a recurrent pattern - a series of criss-crossing filaments that are interlaced into the very nature of the cosmos.

\title{
Buddhism and desire: an emerging position?
}

\author{
Who lives by no craft, unburdened, desiring the goal, \\ With restrained faculties, wholly released, \\ Wandering homeless, unselfish, desireless, \\ Conceit abandoned, solitary - he is a bhikkhu. ${ }^{13}$
}

This verse from the Udāna seems to capture something of the struggle with Buddhist thought represented by Chapters 3 and 4. Here the bhikkhu is described as simultaneously desireless - nirāso ${ }^{14}$ - and desiring the goal - atthakāmo. We have long abandoned the notion that Buddhism seeks the destruction of all desires of all types. Nonetheless, the picture is still not wholly clear. The issue of the possibility of kusala tanhā still persists. I, for one, remain unconvinced of the necessity of admitting such a notion. Furthermore, the attempts we have seen to raise tanh $\bar{a}$ into a cosmological principle are ultimately unconvincing, at least on the basis of the Sutta and Abhidhamma material.

What we have seen though, is a refining of desire. The breaking down of desire into varying categories and types can be seen as negating the seeming paradox of desire mentioned in the introduction. However, it has become clear that the typology of desire I set out to find is only present in part. While there are forms of desire which are seen as qualitatively distinct in ethical terms, this has proven to be only part of the story.

A key issue which has arisen is what ought to happen to akusala forms of desire. This echoes both Hindu debates regarding desire and Buddhist thought on the notion of ditthi. That is, ought they to be removed from the profile of our consciousness, or are they to be transformed? ${ }^{15}$ On one level, one might suggest that this is a pseudo problem, that a transformed desire represents the same thing as its removal. That is, that the two approaches are different ways of describing the same alteration within one's citta. Nonetheless, I am not fully persuaded that this is a sufficient explanation. In part it may be useful, but removal and transformation are not identical.

A transformed phenomenon is still present, ${ }^{16}$ one removed is absent. In that an arahat seems to retain certain types of wishing, one might argue in favour of transformation, but this need not be universal. Some kusala forms of desire may still not be present in an enlightened being - for they would be redundant. The notions of striving examined in Chapter 3 are a vital component of the path, but 
like the raft, are solely for the purpose of crossing-over. Once the journey's end is met, they do not seem to be needed.

We might overall, then, view desire in three ways here. Some desires are suitable for transformation. Types of chanda can be reoriented to kusala objects, and held in a more kusala manner, free of grasping. These may represent the kinds of desires present in arahats and Buddhas - for these beings have goal-driven activity, such as the teaching of the Buddha. Even here though, to be viewed as part of the psycho-spiritual make-up of an enlightened being, these kusala forms of chanda must surely have been radically altered. ${ }^{17}$ Most forms of desiring, as we experience them now, must surely still be transcended - with others undergoing a transformation that may make them analogous to our desires, but qualitatively distinct from them when present in the enlightened.

Others such as tanh $\bar{a}$ need eradicating. This does not rule out the notion of kusala-tanh $\bar{a}$ altogether. For to allow for such a thing does not tie us into a view of tanh $\bar{a}$ as noble or worthy in any final sense. Having seen the kusala-akusala distinction as one that admits of degree, we can clearly see some forms of $\tanh \bar{a}$ as less akusala than others, and maybe - for the individual at a specific point in their spiritual development - more kusala than akusala. Tanh $\bar{a}$ can be best described as becoming kusala when it begins to seek its own destruction.

Third, we can identify things such as padhāna which are kusala, but while they may, in the religious aspirant, represent a transformation of previously held desire, they will ultimately be abandoned by one who has attained the final goal. We do not need as many desires once the goal is attained. The functional, pragmatic, but wholly kusala forms of striving have fulfilled their function, and - like the raft - we can leave them on the banks of the farther shore. This tripartite approach to desires is, I propose, compatible with the evidence I have advanced from the Pali material.

What I now wish to do is to draw together some of the material from the various chapters in a thematic fashion, so as to highlight and investigate a number of the issues which this project has identified. I begin with some reflections on the notion of freedom.

\section{Roads to freedom}

Far between the sundown's finish an' midnight's broken toll We ducked inside the doorway, thunder crashing As majestic bells of bolts struck shadows in the sounds Seeming to be the chimes of freedom flashing. Flashing for the warriors whose strength is not to fight Flashing for the refugees on the unarmed road of flight An' for each an' ev'ry underdog soldier in the night An' we gazed upon the chimes of freedom flashing. ${ }^{18}$

Buddhist, and indeed other, discussions regarding the nature of desire are permeated with references to notions of freedom and liberation. Most commonly we have 
seen this in the context of how insight into the nature of desire, and a certain response to this insight, can be a vehicle for the attainment of freedom.

In many ways, the freedom under consideration here has to be seen as a form of 'negative' freedom. That is, Buddhist notions of freedom are to be understood as freedom from various things. On the most obvious level, the discussion of desire alongside paticca-samuppāda reveals that the concern here is not with the freedom to do what you want, but rather consists in freedom from wanting itself. Of course this is a simplification, but it begins to impart a sense, and a flavour, of the nature of freedom in Buddhist thought.

However, one of the other key thinkers who appeared in Chapter 1, and one whom I will return to here, offers a perspective on freedom that is useful here. Jean-Paul Sartre's notion of 'radical freedom' is so striking, primarily for its presentation of freedom as not inherently a good thing. Furthermore, it is not so much something to be sought, but something we already possess, but which we need to see the nature of in order to manage it properly.

The obvious thing to draw from this is an analogy between this treatment of freedom and Buddhist attitudes to desire. If Sartre sees freedom as dominating the human condition, making us burdened by choice, we might argue that Buddhists see us as burdened with desire, tanh $\bar{a}$ being that which drives our actions. This may be tenable, but in the Sartrean approach we flee our freedom - we deny it - and through acts of mauvaise foi ${ }^{19}$ seek to pretend that we are not free.

Do we flee desire in the same way? At times we might be seen to do so, claiming we act out of necessity, or for some other reason, while our true motivation is the satisfaction of desire. Nonetheless, I am not convinced that we can draw a strong analogy between the two with any general applicability.

Nonetheless, freedom matters here. The whole Buddhist engagement with desire drives at freedom. Few would dispute the view that Buddhist thought sees desire as limiting - and tanh $\bar{a}$-type desires are surely a prison. Not only do they keep us contained within samsāric existence, within that context they limit our ability to find contentment. Many forms of desire, as upsetter, keep us prisoners of turmoil and unhappiness. But while much talk of nibbāna is framed in terms of freedom (from dukkha, from rebirth, from tanha $)$, the road to freedom surely is part-paved with non-tanh $\bar{a}$ forms of desire, and upon it there may even be taṇhä-desire signposts, such a taṇhā for a good object.

\section{Desire and reason: challenging a bi-polar distinction}

Happiness is not an ideal of reason but of imagination. ${ }^{20}$

Surely reason is to be found, first and foremost, at the core of maddest desire! $!^{21}$

In Chapter 1, we saw Plato recommend that reason should rule sovereign over desire, and noted that Buddhism also valued self-control. But Buddhism never seems to split humans into the reason versus the emotions dichotomy 
that we saw many of the Western writers of Chapter 1 using, even though we did find some who questioned this division. A good illustration of this is the notion of mindfulness, which can be seen to regulate both over-active reasoning and inappropriate emotion. Furthermore, mindfulness can also be used to strengthen as well as limit. It can clarify insight, and reinforce states such as sympathetic joy.

In Chapter 4, we saw the suspicion and concern over the holding of views ditthi - and alongside this a concern that takka might well be a source of attachment. We can see a related concern in the work of the notoriously free thinker Nietzsche. We saw in Chapter 1 his admonishment of philosophers for their 'will-to-system', and he eschews many of the traditional preoccupations of philosophers, going as far as asking:

Granted that we want the truth: why not rather untruth? And uncertainty? Even ignorance? ${ }^{22}$

He follows this, a few paragraphs later, with an alternative approach to assessing the worth of a belief:

The falseness of an opinion is not for us any objection to it; it is here, perhaps, that our new language sounds most strangely. The question is, how far an opinion is life-furthering, life-preserving, species-preserving, perhaps species-rearing. ${ }^{23}$

While Buddhism - at least not the type of Buddhism I have been looking at here $^{24}$ - might not go this far, the view that reason is to be secondary to a primary pragmatic concern is present in both these views. This radical challenge is important, it re-orientates us - and makes us as philosophers engaged in a manner that drives towards therapeutic, self-altering ends. Clearly there are parallels with Aristotle here, but he does not go as far as Nietzsche or the Buddha.

Buddhism, in this context, does not have to see reason and desire in conflict. Rather what it does is to view both as potentially useful, but is wary of them as potential objects of attachment and yearning. The suspicion of reason found in some passages in the Pali Canon should not be taken as indicating that Buddhism is irrational, or even non-rational. ${ }^{25}$ Rather, reason is seen not as the goal, but a feature of consciousness that may aid us in our seeking of the goal, but may also be a waypoint capable of waylaying us. ${ }^{26}$ Excessive logical analysis may prevent us moving beyond the very point of insight and development that reason itself has brought us to. ${ }^{27}$

\section{Desire and 'lack'}

This is the monstruosity in love, lady, that the will is infinite, and the execution confin'd; that the desire is boundless, and the act a slave to limit. ${ }^{28}$ 
All desire is bounded by a certain kind of lack - that lack of infinity in the world. While our wants may indeed, and not just in love, be boundless, the world is bounded. From the fact of mortality to the finitude of material resources, whether poet or economist, the world's limitedness hems in the potential for desire's satisfaction.

Our understanding of the relation between desire and lack, or absence, needs to go further than this though. We saw many of the Western thinkers defining desire in terms of absence, as an intentional attitude to something we do not possess. In Hindu thought, the 'lack in desire' ${ }^{29}$ was often viewed as a misperception. Like so much Hindu thought, fulfilling the 'lack in desire' turns out not to be a process of acquiring that which we do not possess - but realising that we already possess it. The true object of all desires is ever-present and at hand - be it in the atman of Advaita-Vedānta, or the Krṇna of theistic bhakti. In these perspectives, the real lack seems to be a lack of insight, or faith, rather than actual absence of a desired object.

Here is where we find a significant contrast with the Buddhist approach. The futility of non-dhamma directed ${ }^{30}$ desires derives from two factors. First, the finitude of embodied (and much disembodied) existence compares, as the quote opening this section demonstrates, with the limitless nature of desire. Second, the type of satisfaction we seek is just plain unavailable. The Buddhist view sees 'lack' in desire as wider than just seeking what we do not have. We seek that which does not, indeed cannot, exist.

So if the Buddhist view is of lack, it is of a different type of lack. Indeed, it would seem that desire is driven by what we might term a 'metaphysical lack'. What seems to lie behind our cravings is indeed an absence, but not solely, or even primarily, the ostensibly desired object. The lack which drives tanhā-type desires is the lack of permanence and stability. It is the emptiness of the universe that leads to desire. ${ }^{31}$

We seek something which will not let us down, which will be reliable. As we have seen, the Buddhist universe contains no Ultimate Being or Brahman-like essence which can provide this. Equally important is the idea that we ourselves lack any such permanence. Both objects of appropriate desire in Hindu thought God and the Self - are either absent, or if present (like devas) are less than we think they are.

This lack of essence at the heart of our being has, since I first encountered the anatta teaching, always put me in mind of the writing of Jean-Paul Sartre. ${ }^{32}$ We can see his notion of mauvaise-foi as an attempt to offer to ourselves a sense of permanence and to give meaning where there is none.

One Western philosopher to connect the existential negation which we find in Sartre and his ilk to Buddhist thought is William Barrett. He paints in broad strokes his view of Buddhist thought, but evokes a powerful image:

In Buddhism the recognition of the nothingness of ourselves is intended to lead into a striving for holiness and compassion - the recognition that in the end there is nothing that sustains us should lead us to love one 
another, as survivors on a life raft, at the very moment they grasp that the ocean is shoreless and that no rescue ship is coming, can only have compassion on one another. ${ }^{33}$

Here he seems to be in error, for indeed Buddhism explicitly teaches of the 'further shore' of nibbāna, but nonetheless his imagery is striking. He sees Sartre's recognition of nothingness as driving him in a different direction though:

For Sartre, on the other hand, the nothingness of the Self is the basis for the will to action: the bubble is empty and will collapse, and so what is left us but the energy and passion to spin that bubble out? Man's existence is absurd in the midst of a cosmos that knows him not; the only meaning he can give himself is through the free project that he launches out of his own nothingness. ${ }^{34}$

While his view of Buddhism may be flawed, and I am not convinced that the directions that the recognition of nothingness sends Buddhism and Sartre in are so opposed, Barrett still offers a valuable insight here. For both, the realisation of the lack of being within leads not to apathy and pessimism. Both Buddhism and Sartre avoid espousing what Barrett calls a 'purely passive nihilism'. ${ }^{35}$

In both Sartrean and Buddhist thought the emptiness at our centre seems almost - to consciousness - like a vacuum, which we try to fill. This attempt to draw in, to fill this gap can be seen as the process which we find manifested in experience as desire. This process whereby the hole at the centre of being would pull into it those objects in its orbits which seem to offer solidity, can be seen as the desire of the pour-soi to become en-soi, of the subject seeking to become objectified.

Like a black-hole that would totally fill itself, but that can never do so, this state of affairs is spiritually - or psychologically ${ }^{36}$ - hazardous. Someone that allows their direction to be set by the desires of a consciousness forever seeking to satisfy itself in this manner is doomed to tread a weary path to misery and frustration:

As a lack of being, consciousness desires to fill itself with the in-itself. Its ideal is be the in-itself-for-itself. But this ideal is unrealizable. Its desire becomes a useless passion. Being unable to realize its ideal, consciousness is subject to constant frustration and suffering; it is unhappy consciousness with no possibility of surpassing its unhappy state. ${ }^{37}$

Of course, as mentioned above, the Hindu position we found in Chapter 2 would vary from this. By directing desire at the ultimate, especially as atman, the foritself can indeed become an in-itself-for-itself - this is surely in line with the notion of spiritual union with brahman.

Others have also seen that underlying most, if not all, desires is a more general desire. The psychologist Lacan sees our drives and desires arising from a wish to 
be 'whole'. He places this sense of being not-whole in childhood - beginning even from the differentiation that occurs at birth when we are one sex or another ('it's a boy' means also 'it's not a girl'). His overall view of desire, albeit couched often in post-Freudian concepts, has a striking resonance with Buddhist thought, which Warren Hedges captures well:

Lacan's notion of desire is, at its heart, a desire for wholeness - a 'hole in the self' that the subject attempts to close through an endless metonymic chain of supplements: the perfect car, the perfect boyfriend, a tenure track job, etc. But as soon as one supplement is acquired, desire moves onto something else. Desire is a (representational) itch than can never truly be scratched. ${ }^{38}$

This, to Buddhist ears, is almost eerily familiar. Of course, the Buddhist view may be described as being able to remove the itch, if not through scratching it. Further, one might consider the 'hole in the self' as akin to notions of anatta. Indeed this whole discussion on the absence that lies at the heart of desire is predicated on anatta. It is because of this structural feature of reality that tanh $\bar{a}$ forms of desire are seen as so problematic.

Were the universe populated by substantial entities, be they ätman or permanent divinity, notions of transformation might well achieve the upper hand in our analysis of what is to be done regarding desire. However, while this might seem to be the case, it is not clear that traditions with such beliefs go down such a road. Hinduism's view on desire does contain this notion, but the transformatory approach is only dominant in some aspects of Hinduism. We do encounter such a view in much Christian thought, where the removal of desire is, anyway, less of a recurrent motif.

There also remains another area where absence or lack with relation to desire requires comment. That is, the lack of desire. In Buddhist thought the absence of desire, as we have seen, is often equated with positive spiritual states. But before we look at the Buddhist view, I wish to look at some other perspectives on the lack of desire.

In Hindu thought, the absence of desire is often equated with 'true desire' desire for God or the Self. We saw this amply demonstrated in Chapter 2. This fits in with the transformatory approach outlined above. We might even see the term 'end of desire' or 'absence of desire' in much Hindu thought as actually indicating 'no mundane desire', 'appropriate desire only' or 'exclusively God-directed desire'. I shall consider shortly whether 'nibbāna-directed desire' could play the same role in Buddhist thought.

Before moving on, though, I want to look at a Western perspective of sorts. While there has been concern over desire, especially among the Stoics and others identified in Chapter 1, the kind of discourse on desire found in both Hindu and Buddhist thought often raises certain concerns in Western thought. The concern relates to the notion that 'passion' is a fundamental and vital (in both senses) 
component of human life. To be 'without passion' is not, in normal social contexts, a compliment. Indeed, we may complain of someone that they 'lack passion'. Are we talking at crossed-purposes here though? By 'passion' in this setting we might actually be trying to indicate something that Buddhism actually has no problem with. We might mean 'ethical commitment', or 'interest in life' but let us not gloss over this with too much ease. Much of what is indicated by this notion is at odds with the Buddhist view - for often it reflects attachment. Western thinking lacks, as we have seen, a mainstream recommendation of detachment as a philosophical and religious ideal. ${ }^{39}$ This notion will be addressed more in detail shortly.

\section{Desire and goodness}

The desire of the righteous ends only in good;

The expectation of the wicked in wrath. ${ }^{40}$

A key concern at the outset of the project was to establish the ethical status of desire, in particular with reference to Buddhism, but also in more general terms. To what extent can we claim to have established such a position? We have seen negative ethical assessments of desire aplenty, but is it desire in-itself that is at fault in these instances? If we consider desire as the means of understanding the nature of the orientation of consciousness towards its objects, then desire would seem to lie at the heart of ethical considerations. By this reckoning, it is when we desire that we express an ethical stance. In some senses, we could extend this approach to 'willing' in general, seeing it as the expression of the inclination of the mind towards the world. The Buddhist concern with the intention behind an act, in the understanding of kamma, is echoed in the famous opening words of the first section of Kant's Grounding for the Metaphysics of Morals:

There is no possibility of thinking of anything at all in the world, or even out of it, which can be regarded as good without qualification, except a good will. ${ }^{41}$

We do not need to adopt a Kantian ethical stance to see the importance of desire to morality. One way to view this relation has often been to see morality and desire as in conflict. One of the main deontological concerns with consequentialist ethics is that they seem to make the desired and the good overly coincide. In a utilitarian ethic, the good seems reduced to the fulfilment of desires. Many would suggest that ethical action is about choosing the good over what we want. On the one hand, this makes ethics the process of doing what we should do, rather than what we want to do. A deeper transformation than this is required though. This deeper change changes us from someone who, despites his desires, does the right thing; it changes us to someone whose desired goals coincides with the good. We can see this as the movement from a person who commits good acts, to becoming a 'good 
person'. While this has the tone of Aristotelian virtue ethics, it matches much of what we have seen with regard to Buddhist thought.

However, one might argue that the Buddhist approach considers desire not as an attempt to redirect our processes of wanting, but as an attempt to suppress some of our most basic human urges (such as sexual urges). The most well-known Western worries over the consequences of the repression of desire are found in Freudian thought.

The Freudian view is that we need an honest dealing with desire, or at least desire as construed as the libido, rather than pushing it away and repressing it. The reason for this stems from a direct recognition of the power of desire - thus its repression is a psychological strategy doomed to fail. Like weeds beneath concrete, desire will always burst forth to sully the cleanliness and order of the repressed mind. This does not mean that desire is to be befriended in order to tame it, but it shows that it requires more than pushing away; we must, for our own mental health, not pretend it does not exist, or hope that if we ignore it, it will just go away.

This seems fair - we can see why this emerges from a Freudian view influenced by Schopenhauer, but some might be tempted to suggest that this is just what Buddhism seems to do. Does not the bhikkhu repress their desires for sex, food after noon, high beds and the like? While I cannot speak for the response of Freudian psychotherapists, Buddhist meditators might argue that their meditation practice is a long way from the repressiveness of aspects of Victorian culture, and the other targets of Freud's concern.

Is not the recognition of the pervasiveness of $\tanh \bar{a}-$ most clearly brought to the fore here by Morrison and Matthews ${ }^{42}$ - an admission of the futility of repression? Furthermore, the path of the Buddhist monastic does not consist solely of abstinence. Abstinence provides only a context - it is not the be-all and end-all of monastic life. A Buddhist position might well be, in response to comments above, that the aforementioned abstinences are needed to provide the psycho-spiritual distance whereby one may begin to understand and deal honestly and openly with the desires that arise within oneself.

\section{Desire and death: seeking the end of the world?}

By walking one can never reach

The end and limit of the world,

Yet there is no release from suffering

Without reaching the world's end.

Hence the wise one who knows the world,

The one who has lived the holy life,

Will reach the end of the world,

Knowing the world's end, at peace.

He no more longs for this world

Nor for any other. ${ }^{43}$ 
In seeking to escape samsāra, we seek the end of life as currently experienced. Furthermore, if desire is the maker of our world - as I argue in the next section then the Buddhist does indeed seek the end of the world, as in the above quotation. This is a powerful and possibly disturbing image, but what more can we say of the connections between death and desire?

In Chapter 1, we saw death linked with desire, Shakespeare offering the most evocative articulation of this link. At a doctrinal level, such a connection might be viewed as absent from Buddhist thought, but there is a way in which we might see them as linked. The figure of Māra embodies both death and kāma, and this is an intriguing idea. He is symbolic of this connection, and we can see how akusala forms of desire might be seen as the enemy of life. They may not, of necessity, hasten death (although they may drive us to risky behaviour at times), but they are an endangerment to the living of a fruitful life. Furthermore, $\tanh \bar{a}$ leads us not only into rebirth, but also re-death - for all that is born is, clearly, of a nature also to die. Desire implicates us then in coming repeatedly back to the act of dying.

In another sense, death is the end of desire - the dead want not, lack not and remain only as the objects of the desires of others still alive. While the Buddhist belief in rebirth extends us beyond a single lifetime, the prospect of our energies coming to an end is, for most of us, one filled with dread. ${ }^{44}$

But desire in the Buddhist view is what drags us beyond this annihilation - an annihilation made impossible by our lack of Self anyway; we return to being - not as the same Self, or a different Self, but as a flow. We continue as process, so that while death is trauma, and death is loss, it is not the end. The only end there can be is a noble end. Clearly there is a double meaning to this. The only worthy end, in the sense of that to be striven towards, is the cessation of all dukkha and rebirth - nibbāna - but this is also the only way to make repeated births and deaths stop. Now it may seem a peculiar religious goal to seek the only way to end life, but is this what nibbāna actually represents?

Is nibbana the final release in the sense of being released from the burden of existence? I do not think it is. First, the nature of nibbāna is contentious, and whatever view we may take, it is explicitly not annihilation. ${ }^{45}$ Second, for the purposes of most humans, we are limited in the depth of our focus - we cannot see beyond this life. Therefore, what Buddhism offers is a way of enriching this life, of reducing the suffering (ours and that of others) in life. As such we can understand Buddhism not as the enemy of life, but as that which can transform life; that which can take an existence of misery and frustration and allow us to transform it into a thing suffused with joy and calm.

\section{Desire, passion and love}

Love!-

you wrench the minds of the righteous into outrage, swerve them to their ruin - you have ignited this, this kindred strife, father and son at war 
and Love alone the victor-

warm glance of the bride triumphant, burning with desire!

Throned in power, side-by-side with the mighty laws!

Irresistible Aphrodite, never conquered-

Love, you mock us for your sport. ${ }^{46}$

In our examination of terms in Chapter 3, there was a serious concern with the problems of 'passion', just as there was a concern with the complexities of love in Chapter 2. As the earlier quote illustrates, where the Chorus bemoan the travails love leads us into, love and passion, while often rated amongst the most valuable aspects of life, are fraught with danger and risk. While it might be tempting to suggest that Buddhism takes the view that this is risk not worth taking, we may wish to go further - perhaps as far as claiming that not only are the odds, in the light of anicca and anatta, - stacked against us, but that our losing is a sure thing, a foregone conclusion.

Is this pessimistic? Surely this is the kind of 'life-denying' approach that Nietzsche found so objectionable. Indeed, many feel that passion and love is what makes life worth living. Harlan Miller, drawing on Aristotle, puts this position very clearly:

Really happy people are those actively engaged in the pursuit of something they really want. Very extensive wantlessness is completely incompatible with happiness. ${ }^{47}$

This is not a rare position amongst Western thinkers, and in Western culture more generally. We can see the alleged value of a life aflame with passion even in religious contexts, as long as the object is the correct one. We saw this in Chapter 2 with regard to bhakti in Hinduism, but can also find it elsewhere, such as in the poetry of Saint Theresa of Avila:

O soul in God hidden from sin,

What more desires for thee remain,

Save but to love, and love again,

And, all on flame with love within,

Love on, and turn to love again? ${ }^{48}$

I have heard numerous friends claim, particularly in response to Buddhist ideas, that the only thing worse than a life ruled by love and passion is a life from which they are absent. This seems directly at odds with a Buddhist position. Indeed, as when discussed in relation to Freud, many feel that not giving in to desire is more dangerous than following the path desire lays out for us:

To be sure, the price to be paid to pursue one's desire is high, but psychoanalytic experience shows that to compromise one's desire exacts perhaps an even higher price. $^{49}$ 
I have already argued that Buddhism seeks something other than the 'suppression' of desire, but does it seek to - in its concern with desire - drain our life of some valuable quality? Such a claim, that Buddhism seeks to drain the passion from life, to flatten out the highs and lows of our emotional landscape, must not go unchallenged.

One might argue that the process of self-transformation that Buddhism seeks to initiate is a form of emotional housekeeping. In moving from a tumult of cascading emotions, ripping continuously through consciousness, we may begin to move to a smaller number of vitally important psycho-spiritual processes. Buddhism seeks, for example, to promote a depth of compassion that normal, un-calmed, consciousness simply has no room or time to develop. The image of the Buddhist in the preceding paragraph is of an unfeeling, automata-like being that bears little resemblance to the ideals of character found in Buddhism. ${ }^{50}$

The development of calm is important, but does not preclude feeling. Rather it is a precondition for the development of selected mental states to a fuller, richer and more 'skilful' (kusala) level. It is in this context that I suggest that the Buddhist project allows the individual to develop a well-crafted life. Life is something to be mastered; we do not do it well out of sheer instinct, but - in my reading of the Buddhist view - we must develop competency in it. Insight into the nature, role and causal processes of desiring lie at the heart of this development.

\section{Desire and contingency: change and craving}

He who binds to himself a joy

Does the winged life destroy;

But he who kisses the joy as it flies

Lives in eternity's sun rise. ${ }^{51}$

The ultimate root of desire's futility has been seen to be change. We saw this in Chapter 1 with Seneca, and others. Excepting Christian thought, as beyond the scope of this investigation, we see that only Hinduism seems able to find an appropriately permanent object of desire. Even nibbāna was ambiguous as an object of desire, due to concerns about how we want it.

What we find in the quotation from William Blake, above, is something also found in much Buddhist thought - the need to reconcile ourselves to transience. This is at the heart of the Buddhist rejection of claims that it is pessimistic. Furthermore, this should help us understand the ideas of the previous section that it is not so much the wanting of things that is necessarily problematic; it is rather the manner of our wanting that is critical. If we can learn to appreciate the world in the context of change, of transiency, only then can we come to a life that is capable of painless joy. In a piece written for a sick friend, the Greek poet Pindar ${ }^{52}$ gives a sense of how we must match our ambition to our realities:

- We must ask from the Gods

Things suited to hearts that shall die,

Knowing the path we are in, the nature of our doom. 
Dear soul of mine, for immortal days

Trouble not: the help that is to be had

Drain to the last. ${ }^{53}$

Until we achieve learn to live with both limit and transience, we can all too easily see what the Russian poet Anna Akhmatova gets straight to the heart of, in one of her short, untitled pieces:

What's war? What's plague? We know that they will pass, Judgement is passed, we can see an end to them. But which of us can cope with this fear, thisThe terror that is named the flight of time. ${ }^{54}$

\section{Desire and power: the creative craver}

I led you away from these fable-songs when I taught you:

'The will is a creator.' 55

Desire is a powerful force: this much stands beyond doubt at this stage. It is the nature of this power and the manner in which it expresses itself that is at stake here. Part of how desire can be seen to create the world we live in as experiencing beings is linked to tanh $\bar{a}$ 's long-term partner - avijja $\overline{\text {. It }}$ is through the way that we view the world - deeply conditioned by avijj $\bar{a}$ - that we come to experience the world in terms of desire. One of the most fundamental misperceptions of reality is the belief in the Self - which drives much of our desiring. This is so because we then move to act, cognise and emote in relation to the world in the context of how it applies to the Self, to 'I'.

Buddhists are not the only ones to realise the extent to which we make the world around us, or the world-as-we-experience-it via our internal processes. Sartre presented an introductory study of how the emotions (which in his approach seems to include desire) in his The Emotions: Outline of a Theory, ${ }^{56}$ about which Leslie Stevenson writes:

This view.... is that emotions are not things which 'come over us', but ways in which we apprehend the world. ${ }^{57}$

This seems to echo what has just been said about the Buddhist position. Desire can be seen as just such a thing. Although we saw, in Chapter 2, desire as coming upon God in this way, it seems that for most of us, desire is a fundamental factor in how we apprehend the world. But, and linked with avijja , it is more than this; desire is what makes our lived world-of-experience ${ }^{58}$ what it is. As discussed in Chapter 4, the Buddhist view strongly suggests that desire is the means by which we shape the world. In this sense it can be clearly understood as creative. But does it go beyond this? Is desire creative in a sense that transcends the individual? 


\section{Desire beyond the person: cosmic desire}

The earth and sky were patterned through an intention; wind and space were patterned through an intention; water and fire were patterned through an intention. ${ }^{59}$

Desire has, throughout this study, often been seen not as something that just arises in a specific person for a specific object. This began in Chapter 1, where we found desire discussed in terms of being a general principle, of which individual acts of wanting are merely specific instances. This is most clearly found in Schopenhauer, where the Will acts as a world-making metaphysical principle. However, he is not the only thinker to do this, although he does it to probably the greatest extent of those discussed in Chapter 1.

Some have a more psychological approach, where desire arises in a general sense, and then later takes an object. I have said little regarding Freud, his interests coinciding with mine here only briefly, but we can see a useful connection that echoes some of the ideas raised in the conclusion to Chapter 1:

There is also a noteworthy resemblance between Freud and Buddhism in emphasizing the role of the 'instincts' more than that of the 'object'. In the last analysis what is emphasized in Buddhism is not the object or the sense organs, but the persistence of desire and lust. Freud says that the sexual instinct is in the first place independent of its object. ${ }^{60}$

Here 'sexual' is very broad, not a narrow desire, as in Freud's usage it encompasses more than mere lust. We have seen some (particularly Robert Morrison) suggesting a pervasive role for tanha ; here it is a metaphor for existence, the first instinct which drives life. On closer examination the early Buddhist texts do not wholly support this. Rather desire is not by itself anything; in the context of paticca-samuppāda nothing is. Rather than a creator, desire is a condition (and conditioned); it is part of the process.

In the sense discussed in the previous section, desire is the maker of worlds - it is a dominant, if not solitary (especially if we consider the status of avijjā), component of our mental machinery. Nonetheless, if we wish to grant it, as we saw some do in Chapter 2, the role of metaphysical principle - the maker of the external, empirical world - we will have to do so outside the context of the Pali Canon.

\section{Lust for life: desire and skilful living}

The same expedient - castration, extirpation - is instinctively selected in a struggle against a desire by those who are too weakwilled, too degenerate to impose moderation upon it. ${ }^{61}$

This quote offers an intriguing perspective, and gives a sense that Nietzsche believes that the often extreme rejection of desire - particularly when expressed 
via the vilification of the body and the desires connected with it - is based on the inability of those who preach such a line to control their desires. As he says later in the same section:

Survey the entire history of priests and philosophers, and that of artists as well: the most virulent utterances against the senses have not come from the impotent, nor from ascetics, but from those who found it impossible to be ascetics, from those who stood in need of being ascetics. ${ }^{62}$

From this comment, which is rather ungenerous, we get a sense of the frustration of those engaged in combat with what their senses drive them to. I take from it the notion that many misconceive the problem of desire. Rather than just fighting desires, blaming ourselves for their presence and striving against them, we need to dig deeper. What is needed, I feel, is to gain insight into the causes and consequences of desire. Only then can we strive calmly, rather than in haste, panic, guilt and fear. The preceding chapters have led me to the view that the 'core value' that one finds in the Pali Canon is neither insight nor compassion - though both are corollaries of it. For me, the key here is calm. Calm allows us to assess desires to make kusala-akusala judgements - and to harness or release desires as we see fit. A fear of desire is as potentially dangerous as abandoning ourselves to its hedonistic embrace. If we see desire as the upsetter, then the overcoming of desire lies not in fleeing from it like a startled beast. Rather, spiritual victory lies in stillness - in equanimity.

Contentment is of great value in Buddhist thought, and beyond. Contrasting with the desire for a life burning with passion, aflame with desire, contentment may appear dull. Indeed the path of contentment is all too easily associated with lethargy, apathy and complacency. Clearly the Buddhist view emphasises on that which has to be done prior to contentment, the energy we must muster, and the work (albeit meditative) laid out for the monk or nun; this is not lethargy. All the same the attitude of many people to contentment is ambivalent.

In reflecting on Western perspectives, it would be too easy and inaccurate to say that contentment is undervalued. Actually, from the stoics onward, we find a healthy tradition of the seeking of peace. In the end, the Buddhist material offered only a partial typology of desire, but in many ways it offered much more than this. Its response to desire is not born out of fear, nor enmity, but seeks to be therapeutic, as much as it is philosophical. Indeed, rather than leading us away, out of our personal thoughts into abstracted forms of reasoning, its intent seems to be to turn us back upon ourselves - to turn us inward - so that we may face our desires head on. Only then can we come to a reckoning with them, and may, armed with a stilled and calm consciousness, in the end overcome. 


\section{GLOSSARY}

This short glossary is to assist the reader unfamiliar with Indian religious thought. It does not seek to engage with theoretical issues related to the terms involved, as this - where necessary - is contained within the main body of the book. (S) Indicates a Sanskrit term, and (P) indicates a Pali term. For some words I have given both the Pali and Sanskrit versions.

Anatta (P) Not Self. To describe something as anatta is to claim that it is not Self, or does not possess the qualities of a Self.

Anicca (P) Impermanent.

Arahat (P) One who has attained nibbāna. The term does not usually include the Buddha though, but rather one who has reached the goal by following the teachings of Buddhism.

$\bar{A} \boldsymbol{s} \boldsymbol{a v a}(\mathrm{P})$ Taint, or stain; these are negative aspects of our mental make up.

$\operatorname{Avidy} \overline{\boldsymbol{a}}(\mathrm{S}) ; \boldsymbol{A v i j j} \bar{a}(\mathrm{P}) \quad$ Ignorance. In the Buddhist paticca-samuppāda formula, avijj $\bar{a}$ is the 'first link' in the process leading to repeated birth, and the suffering inherent therein.

Atman (S); Atta (P) The Self. Often identified with the universal brahman in some Hindu philosophy. See anatta, above, for the Buddhist view.

$\boldsymbol{B} \boldsymbol{h} \overline{\boldsymbol{a}} \boldsymbol{v a}(\mathrm{P})$ Being, existence, becoming. The opposite vibhāva is non-being, non-existence. They are two of the three types of tanha (the third is $k \bar{a} m a-\tanh \bar{a})$.

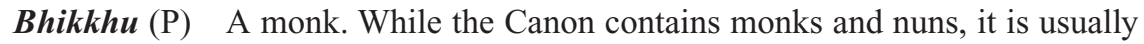
monks who are addressed.

Brahman (S) In Hindu thought, this is often used to refer to an impersonal divine essence. It can be seen as a 'universal ground of being', and sometimes acquires a pantheistic tone, especially when identified with Ätman.

$\operatorname{Cetan\overline {a}}(\mathrm{P})$ Will, intention.

Chanda (P) Desire. Often described as 'desire-to-do'.

Deva (P, S) A deva is a God in both Hindu and Buddhist terminology, although their nature and status varies greatly between the two religions.

Dharma (S); Dhamma (P) A difficult term to define, in either its Pali or Sanskrit usage. Used in the sense of the teaching of Buddhism (for this usage I capitalise 
Dhamma). It is also used to represent mental states, and more loosely as a 'thing'. In Abhidhamma thought it represents a process or event.

Ditthi (P) Views, beliefs, opinions - most commonly translated as 'views'.

Dukkha (P) While often translated as 'suffering' it has a wider scope it includes mental and physical suffering, but also our dis-ease with life - the subtle sense in which all life is unsatisfactory.

Jhāna (P) Meditation state.

Kāma (P, S) Desire, particularly sensual desire. In Hindu use often explicitly associated with sexual desire (as in the Käma Sütra), but also used as a general term. Sometimes, in Hinduism, found personified as a 'god of love'. In Buddhist use kāma usually indicates sensual desire. It should be noted that it is used to refer both to the desire, and the object of desire.

Karma (S); Kamma (P) Literally, action. Used in association with the notion that actions lead to certain types of results. Most often karma is associated with the notion of how our actions affect the nature of our rebirth, but is not limited to this.

Kilesa (P) Defilement - negative mental states.

Kusala (P) While sometimes used as 'good' (in a moral sense), more usually translated as 'skilful'. The opposite is akusala. This term is discussed in the Introduction.

Nirodha (P) Cessation.

Nirvāna (S); Nibbāna (P) The final goal of Buddhism. The nature of nibbāna is complex and controversial. It is the end of rebirth, and the end of all dukkha.

Padhāna (P) Striving, exertion - normally here in a spiritual sense.

Pațicca-samuppāda (P) Conditioned-Arising (sometimes found as 'Dependent Origination', or even 'Conditioned Co-production').

Phassa (P) Contact.

Samsāra (P, S) Literally 'wandering on' - the cycle of rebirth (and re-death).

Sankappa (P); Samkalpa (S) Intention. In its Sanskrit use, often associated with 'ritual intention'.

Takka (P) Reason, reasoning.

Tanh $\overline{\boldsymbol{a}}(\mathrm{P})$ Craving, thirst.

Tathāgata (P) A 'thus-gone' one. A term for one who has attained nibbāna.

Upādāna (P) Grasping.

Vedanā (P) Feeling.

Vibhāva (P) See bhāva.

Viñ̃āna (P) Consciousness. 


\section{NOTES}

\section{INTRODUCTION: DESIRE, MORALITY AND APPROACHES}

1 Ecclesiastes, 6.7-9. Bible, RSV.

2 I use the term 'spiritual' with caution. By it I do not indicate 'the sense of awe and wonder' that many equate it with (not the least of these being the compilers of school curricula), but rather that aspect of our make-up as persons which responds to art, religion, ethical feeling and the like. This may be a part of our psychological profile, but due to its importance and distinctiveness, I use the term to move us away from the rest of our psychology, to indicate that which communes with the sublime.

3 Keown, D., The Nature of Buddhist Ethics. p. 222.

4 Herman, A. L., 'A solution to the paradox of desire in Buddhism.' In Philosophy East \& West. Vol. 29.1, 1979, p. 91. http://sino-sv3.sino.uni-heidelberg.de/FULLTEXT/ JR-PHIL/ew26801.htm [Accessed 01/05/2002].

5 Ibid., p. 93.

6 By 'Desire 1' Alt means the desire to be rid of desire. The desire we wish to be rid of, the object of 'desire1', he refers to as 'desire2'.

7 Alt, W., 'There is no paradox of desire in Buddhism.' In Philosophy East \& West. Vol. 30.4, 1980, p. 527. http://pears2.lib.ohio-state.edu/FULLTEXT/JR-PHIL/wayne. htm [Accessed 01/05/2002].

8 Ibid., p. 527.

9 Visvader, J., 'Reply to Wayne Alt's "There is no paradox of desire in Buddhism".' In Philosophy East \& West. Vol. 30.4, 1980, p. 534. http://pears2.lib.ohio-state.edu/ FULLTEXT/JR-PHIL/john2.htm [Accessed 01/05/2002].

10 Ibid., p. 535.

11 Herman, A. L., 'Ah, but there is a paradox of desire in Buddhism - A reply to Wayne Alt.' In Philosophy East \& West. Vol. 30.4, 1980, p. 530. http:// pears2.lib.ohio-state.edu/FULLTEXT/JR-PHIL/herman2.htm [Accessed 01/05/ 2002].

12 Ibid., p. 531.

13 Davids, R., 'On the Will in Buddhism.' In The Journal of the Royal Asiatic Society of Great Britain and Ireland. Vol. 1, 1898. p. 55.

14 In this sense we might also consider this to include negative forms of desire, such as aversion.

15 Anscombe, G. E. M., Intention. p. 68. Cited in Schueler, G. F., Desire. p. 1.

16 Schueler, G. F., Desire. p. 1.

17 Ibid. 
18 We are, from a Buddhist position, seen as explicitly having desires that we must combat, for example, Dhp. 336:

Whoever in this world, overcomes this hard-to-overcome, base craving,

From him sorrows fall, like water drips from a lotus.

Yo cetam sahate jammiṇ, taṇhạ loke duraccayam,

sokā tamhā papatanti, udabinduva pokkharā.

19 For example, to obtain certain qualifications, or to secure the love of a good woman.

20 Schueler, G. F., Desire. pp. 9-10.

21 Ibid., p. 10.

22 Ibid., p. 11.

23 Ibid., p. 11.

24 If he wishes the car would start more easily, he must have a desire for this - wishing involves desire. Ibid., p. 14.

25 This is, I feel, not the problem he makes of it. If you point a gun at me, as in the example, and tell me that I must drink another cup of coffee or you will kill me, my 'desire to drink a coffee' evinced by my actually drinking it, is surely an expression of a more fundamental desire - not to be shot!

26 Plus, of course, an inner conflict can arise when our competing desires within us do not coincide. A desire to be healthy, and a desire to gorge oneself on cream cakes are likely to lead to an inner-conflict of desires as we stand at the door of the fridge.

27 See, for example, M.I.137.

28 Never mind that once we do get what we want, we all too often decide that it wasn't what we wanted after all, or that we now want something else. In some ways I am reminded here of a child's tantrum - once one finally caves in and gives them the sweet they were crying for, they decide that the one they actually want is the one they rejected at the shop, and you no longer have with you.

29 Dollimore, J., Death, Desire \& Loss in Western Culture. p. xii.

30 In one sense we might claim that Abhidhamma provides a glimpse into early Buddhist self-understanding - the way that early Buddhism came to an appreciation of what was indicated in the suttas.

31 For a complete opposite of this view, albeit somewhat on the verges of contemporary 'Analytic' thought, see A. J. Ayers's anti-metaphysical classic Language, Truth and Logic, particularly Chapters 1 and 2.

32 For a slightly expanded version of this distinction see Teichman, J. and Evans, K., Philosophy: A Beginners Guide. pp. 6-7.

33 Gombrich, R., How Buddhism Began. p. 14.

34 Johansson, R. E. A., The Dynamic Psychology of Early Buddhism. p. 101.

35 To which a quick Buddhist answer is 'no one' (in the context of anatta - not Self), there just is desire.

36 I had, originally, entitled this chapter 'The Mechanics of Desire'. This was, ultimately, felt to portray, as it were, too mechanistic (and possibly reductionist) a picture of the Buddhist understanding of persons. 'Dynamics' seeks to capture more fully the Buddhist approach to our nature as persons.

37 Goethe, 'Spruch, Widerspruch' ['Saying and Gainsaying']. In Goethe, Selected Verses. p. 287.

38 For a definition of this concept, central to Islamic jurisprudence, see Coulson, N. J., A History of Islamic Law. p. 40.

39 In the sense of component of reality, particularly our mental make-up. 
40 Thich Nhat-Tu, B., 'Kusala and Akusala as Criteria of Buddhist Ethics.' Buddhism Today (original publication), downloaded from http:/quangduc.com/English/ kusala.htm [Accessed 13/01/01].

41 PED, p. 223.

42 Ibid., Puñña (see PED, p. 464) is probably the key positive moral term in Buddhist thought, indicating meritorious actions.

43 Cousins, L., 'Good or Skilful? Kusala in Canon or Commentary.' In Journal of Buddhist Ethics Vol. 3, 1996. p. 143.

44 I shall discuss 'Wholesome', another popular translation of kusala, later in this section.

45 Such as the skill of musicians at D.II.183.

46 Keown, D., The Nature of Buddhist Ethics. p. 116.

47 Ibid., p. 119.

48 Presumably he here means from the moment it is expressed as an act of will or volition - as cetanā.

49 Keown, D., The Nature of Buddhist Ethics. p. 177. Keown's second objection, on the grounds that the consequentialism of utilitarianism is opposed to the Buddhist concern with intention, is interesting, and strong against J. S. Mill's conception of the utility principle, but may have weaknesses against more sophisticated contemporary forms of utilitarianism.

50 Another term I might have chosen is 'wholesome', which has some currency in contemporary (e.g. Maurice Walshe uses it in his LDB) Buddhist studies, and which I do use at points where it seems to capture the sense of what is said better than 'skilful'. While 'wholesome' may represent a middle position between Keown's view and 'skilful, he maintains his original position. In a recent e-mail, a gracious response to my request for an update in his view of kusala, he writes

'Wholesome' now seems to be the favoured term, although I cannot understand what is wrong with the simple English word 'good'!

51 While the abhidhamma makes a distinction between dhammas that are kusala or akusala, within its distinction of type, relative degrees of kusala-akusala status are clearly present.

52 Produced by the Vipassana Research Institute. See www.vri.dhamma.org for details for this resource. I have used Version 3 of the CSCD for access to the great wealth of Pali texts it contains. As well as the Canon it contains commentaries, sub-commentaries, and post-Canonical works such as the Milindapñha.

53 Which draws on a number of manuscript traditions. All Pali text contained in this book is from the CSCD, unless otherwise indicated. Version 3 of the CSCD has the PTS pagination, so unless otherwise indicated, I use the PTS pagination for reference purposes.

54 I have used, for the examination of Pali terms, the PTS's Pali-English Dictionary (PED). Towards the end of my writing, the PTS published the first volume of Margaret Cone's new A Dictionary of Pāli. I have sought to make some use of this new work, which improves greatly on the PED. However, I have not made quite as much use of this new work as I would have been able to do had it been published a year or two earlier.

55 Later revised, when recently republished in WBR to Two Cheers for Tanh $\bar{a}$. I have not discussed whether this downgrading of $\tanh \bar{a}$ 's cheers-quotient is significant for his position though...

\section{DESIRE IN WESTERN THOUGHT}

1 Hill, G., 'The Pentecost Castle', section 15. In M. Schmidt (Ed.), Eleven British Poets. p. 202. 
2 Butler, J., Subjects of Desire. p. 1.

3 Or set of inter-related ones. While they may be called 'desire', their referent may subtly differ. It is all the harder to identify the referent of a term when it is mental notions we are discussing.

4 Buddhism has a very specific agenda - that of the reduction (and final elimination) of $d u k k h a$ (suffering/unsatisfactoriness). The most famous verse on this is probably that at M.I.140:

Bhikkhus, both formerly and now, what I make known is dukkha and the cessation of dukkha.

Pubbe cāham bhikkhave, etarahi ca dukkhañceva paññapemi, dukkhassa ca nirodham.

5 In Beyond Good and Evil, Chapter 1 On The Prejudices of Philosophers, Nietzsche lectures us in a disagreeable tone, but with good reason, about avoiding the concealment of ethical goals in metaphysical systems. I hope my ethical aims were made sufficiently clear in the Introduction. Nietzsche's writing in Beyond Good and Evil on this may be seen to partly echo what I say in Chapter 4 about the Buddhist approach to the holding of, and attachment to, views (ditthi).

6 Fuery, P., Theories of Desire. p. 4.

7 We might compare this with the Hindu use of the term käma.

8 He seems as good a scapegoat as any, and is probably familiar in the role.

9 Stevenson, L., Seven Theories of Human Nature. p. 66.

10 An explanation of Schopenhauer's approach is given later in this chapter.

11 Solomon, R. C., Continental Philosophy Since 1750. p. 143.

12 Ibid., p. 143.

13 Though Schopenhauer might.

14 'so has every act of will a motive, but the will in general, none; in fact, at bottom these two are one and the same.' Schopenhauer, Arthur, The World as Will and Representation. Vol. 2, pp. 358-9.

15 Blake, W., 'There is No Natural Religion.' In P. H. Butter (Ed.), William Blake: Selected Poems. p. 8.

16 Who took the opposite view to Heraclitus - denying that the world was in flux to the extent that all motion and change was denied.

17 Schueler, G. F., Desire. p. 9.

18 His overall notion of desire is addressed in the introduction.

19 Stevens, Wallace, 'Notes Toward a Supreme Fiction.' In Stevens, Wallace, Selected Poems. p. 99.

20 Goodheart, E., Desire and its Discontents. p. 1. Goodheart goes on to place Dostoyevsky, Hume and Nietzsche in what he calls a 'counter tradition' to this view. We shall examine these thinkers shortly.

21 Dollimore, J., Death, Desire \& Loss in Western Culture. p. 50.

22 Armstrong, J., The Conditions of Love: The Philosophy of Intimacy. p. 60.

23 Plato, The Symposium. pp. 76-77. III.200.

24 Plato, The Symposium. pp. 76-77.

25 The myth is older than Plato, and found in Aristophanes. For a detailed account of Aristophanes' account see Vernant, Jean-Pierre, 'One... Two... Three: Erōs.' In D. Halperin et al. (Eds), Before Sexuality: The Construction of Erotic Experience in the Ancient Greek World. p. 471.

26 Armstrong, John, Conditions of Love: The Philosophy of Intimacy. p. 32. This idea fits rather neatly with many of our contemporary romantic notions, such as 'they were made for each other', 'you complete me' and the like.

27 Dollimore, J., Death, Desire \& Loss in Western Culture. p. 13. 
28 Seneca, Epistula Morales I.17, as quoted by Dollimore, Ibid., p. 25.

29 Dollimore, J., Death, Desire \& Loss in Western Culture. p. 24. This has clear echoes with the Buddhist approach, where anicca is what makes tanha $\bar{a}$ so forcefully leading to dukkha.

30 Plato, The Republic. 439e-441d.

31 Although 'appetite' fits more closely with desire, we might also see 'spirit' as related to ideas of the will.

32 Plato, The Republic. 441e.

33 Ibid., $442 \mathrm{~d}$.

34 Aristotle, The Nicomachean Ethics, VI.2, p. 138.

35 Ibid.

36 Although it is only of peripheral relevance, I have always been struck, when reading Ecclesiastes 3 ('For everything there is a season and, a time for every matter under heaven...') of how much it makes me think of notions of 'thus-ness' or 'such-ness' in some Zen Buddhist thought. Ecclesiastes 3 is a watching of the nature of things, of the profundity of world as fact that puts me in mind of Basho's Haiku.

37 Ecclesiastes, 1.1-3. The Bible, RSV.

38 Ecclesiastes, 1.13-5.

39 Dollimore, J., Death, Desire \& Loss in Western Culture. p. 38.

40 Ecclesiastes, 6.7-9.

41 Ecclesiastes, 5.10. This is rather like some of the views we will see advanced by Schopenhauer later in this chapter.

42 The author of Ecclesiastes - 'the preacher', traditionally seen as Solomon. See J. Bowker (Ed.), The Oxford Dictionary of World Religions. p. 302.

43 Dollimore, J., Death, Desire \& Loss in Western Culture. p. 41.

44 See A.III.134 and Ud. 3.10.30.

45 St Augustine, Confessions. Book III, Part I, p. 55.

46 Ibid.

47 Armstrong, J., Conditions of Love: The Philosophy of Intimacy. p. 61.

48 Psalms, 42.1-2.

49 Job, 14.1-2.

50 Shakespeare, Sonnet 147. The Alexander Text of William Shakespeare: The Complete Works. p. 1333.

51 In Buddhist contexts, medical analogies are common. The Four Noble Truths often are seen as Symptom, Diagnosis, Cure and Prescription, cf. Anderson, Carol, Pain and its Ending.

52 Dollimore, J., Death, Desire \& Loss in Western Culture. p. 104.

53 Or maybe we could see his view as being that this desire is a death - a death of life having value or meaning.

54 This notion of 'therapeutic rationality' is one I draw in part from the ideas of Aristotle. This idea is followed up in Chapter 5.

55 Dollimore, J., Death, Desire \& Loss in Western Culture. p. xii. He spends much of the book on this notion, and for those wishing to look at this in more detail, it is a heady and instructive read.

56 Randolph, T., 'An Elegie.' In Helen Gardner (Ed.), The Metaphysical Poets. p. 131.

57 Hobbes, Leviathan, Part I, Chapter 6.

58 On a close reading, this is not as utilitarian as it may seem. Clearly, such a view differs from a Buddhist ethics built on notions of kusala, although we could build up a model of structural symmetry: we call it good because we desire it (Spinoza); we call it kusala because it leads to reduction of dukkha. Further comparative analysis is presented in Chapter 5.

59 Spinoza, The Ethics, Part III, Proposition 9.

60 Locke, J., An Essay Concerning Human Understanding. p. 160.

61 Hume, D., A Treatise of Human Nature. Book 2, Section 3, p. 462. 
62 Hume, D., A Treatise of Human Nature. Book 2, Section 9, p. 486.

63 Clearly this debate has some connection with the approach of Spinoza, and this link between what we do want and what we should want is a thread that runs through much Western ethical thought.

64 This distinction echoes the note above, and the 'desirable' is used to refer to what we should want!

65 See Moore, G. E., Principia Ethica. Chapter III, A, Sections 39-44.

66 First published in 1818 , followed by the significantly expanded version, published in 1844.

67 See the Introduction on the extent to which 'will' and 'desire' can be used together in these ways.

68 Should we be convinced by this assertion that lack is based on suffering? A Buddhist account might reverse the two, seeing dukkha as based on anicca (as lack of stability), or anatta (as lack of substantiality). Schopenhauer seems convinced that lack of wholeness is miserable - that completion is the unobtainable goal we crave. This clearly echoes the Platonic approach in the Symposium, and to an extent foreshadows the work of Lacan.

69 Schopenhauer, A., The World as Will and Representation. Vol. 1, p. 196.

70 While the Jains merit a mention in the Supplement, [The World as Will and Representation. Vol. 2, p. 608.] it is not one I imagine to be to their liking: 'the Jains, who differ from the Buddhists only in name...'

71 SED, p. 811.

72 Ibid.

73 A relationship oft speculated about in earlier Hindu texts, alongside the Vedic discussion of the state of dreamless sleep.

74 Although 'in the dark' - given its colloquial use and Plato's cave imagery - seems to refer to much of what he means by illusion. Ignorance is less evocative than 'Illusion' but surely - at least for much of what Schopenhauer says - no less accurate.

75 Schopenhauer, The World as Will and Representation. Vol. I, p. 17.

76 Solomon, R. C., Continental Philosophy Since 1750. p. 77.

77 Ibid., p. 75.

78 A Buddhist might argue that some senses of tanhā are subtle and deeply ingrained, being a general churning or disturbance in the mechanisms of consciousness - other senses of desire as general disturbance are explored in Chapter 3.

79 Schopenhauer, The World as Will and Representation. Vol. I. p. 165.

80 Ibid., II, pp. 358-9.

81 Solomon, R. C., Continental Philosophy Since 1750. pp. 78-9.

82 Schopenhauer, The World as Will and Representation. Vol. II, p. 394.

83 Ibid., Vol. 2, p. 394 - he eulogises here at length of the relative freedom from the will that we enjoy in 'the morning sunshine of life'.

84 Clearly the Will is not identical with the replication-seeking gene, but both can be seen as being blind and purposeless. We might see the 'selfish gene' in a similar fashion to the Will, seeking only to further its existence.

85 Schopenhauer, The World as Will and Representation. Vol. II, p. 550.

86 Ibid., Vol. II, p. 550.

87 MacIntyre, A., A Short History of Ethics. p. 222.

88 This often puts me in mind of temporary meditative calming - once one has finished, and is back in the 'world', the calm begins to evaporate rapidly. Nonetheless, many would argue that such calming has more than a short-term effect on a person.

89 Solomon, R. C., Continental Philosophy Since 1750. p. 84.

90 The original version of the book, before Schopenhauer added the Supplements that now form the second volume.

91 Schopenhauer, The World as Will and Representation.Vol. I, p. 410. 
92 Schopenhauer often seems closest, albeit implicitly, to a Yogācāra view, but this also has echoes with the early Buddhist idea of nibbāna as the 'cessation of the world' loka-nirodha.

93 Schopenhauer, The World as Will and Representation. Vol. I, p. 411.

94 Sødring, C., Hamlet beyond death. Unpublished conference paper. Presented at Desire: Eighth International Philosophy Graduate Conference, University of Essex, 28th June, 2002. p. 12.

95 Schrift, A. D., 'Spinoza, Nietzsche, Deleuze: An Other Discourse of Desire.' In Continental Philosophy: Philosophy \& Desire, Vol. VII, 2000. p. 178.

96 See Nietzsche's The Genealogy of Morals. Vol. III, Section 28.

97 Lee, J. H., 'Sovereign "Subjectivity" in Bataille.' In The Journal of the British Society for Phenomenology. Vol. 32, No. 1, 2001. p. 46.

98 The Deleuze Reader, p. 114. Originally in Deleuze, Dialogues.

99 Deleuze and Guttari, A Thousand Plateaus. p. 399.

100 As we read in Beyond Good and Evil:

the noble man also helps the unfortunate, but not - or scarcely - out of pity, but rather from an impulse generated by the super-abundance of power.

Nietzsche, F., Beyond Good and Evil. Para. 260, p. 127.

101 See Schrift, A. D. In 'Spinoza, Nietzsche, Deleuze: An Other Discourse of Desire.' p. $173 \mathrm{f}$.

102 Sartre, J.-P., Being and Nothingness. p. 21.

103 We will in later chapters see whether this model of duality originating in misguided views of self-hood leading to the postulation of external goods/objects of desire in a Buddhist context is found in the Pali Canon.

104 Desire is like the will maybe - for Nietzsche, and probably for some of the others we have looked at. We would rather will nothingness than not will - the pervasive will, sublimated maybe, but ever-present.

105 Lechte, J., Fifty Key Contemporary Thinkers. p. 104.

106 And to an extent, as I demonstrate in Chapter 2, like the Veda-Samhitās. Furthermore, a number of contemporary Continental philosophers seek to incorporate desire into the discourse-lineage of Marxist and Hegelian thought. While this is beyond current purposes, books such as Lyotard's Economie Libidinale politicise desire and seek to locate it in the realm of socio-political construction.

107 We might also wish to consider parallels between Nietzsche's notion of the Will-toPower, especially when sublimated, and the notion of turning desire upon itself found in some later Buddhist texts - see Bernard Faure's The Red Thread: Buddhist Approaches to Sexuality, where he discusses this in some detail.

108 Stoeber, M., Dostoevsky's Devil: The Will to Power. In The Journal of Religion. Vol. 74, No. 1, January 1994, p. 30.

109 See, for example M.I.39. Translation, from MLB. p. 138:

"Yato kho, āvuso, ariyasavako evam tanham pajānāti, evam tạnhāsamudayạ̣ pajānāti, evam tạnhānirodham pajānāti, evam tạnhānirodhagāminim pațipadạ̣ pajānāti, so sabbaso rāgānusayam pahāya ...pe...dukkhassantakaro hoti-ettā̄y vatāpi kho, āvuso, ariyasāvako sammādiț̣thi hoti, jugatāssa dițthi, dhamme aveccappasādena samannāgato, āgato imam saddhamman" ti.

When a noble disciple has thus understood craving, the origin of craving, the cessation of craving, and the way leading to the cessation of craving... he here and now makes and end of suffering.

[This is the full passage in Pali, in MLD some sections are omitted]. 
110 Stoeber, M., Dostoevsky's Devil: The Will to Power. pp. 27-8.

111 Rather like the Vedic sacrifice whereby things come to be via Samkalpa. See Chapter 2.

112 Stoeber, M., Dostoevsky's Devil: The Will to Power. p. 30.

113 Ibid., p. 31.

114 Ibid., Stoeber moves on to implore us to reject the will-to-power. He concludes by presenting the reader with a stark choice (p. 44): 'So I leave readers to ponder for themselves the basic question - the primacy of will or of God.' Buddhists may be tempted to steer a middle-path between the primacy of either...

115 Dostoyevsky, F., Notes from the Underground, p. 7. This phrase makes one think of Petas, the ghost-like rebirth of those whose cravings are so strong as to keep them tied close to their prior existence. See PED, p. 472, the various categories of petas are discussed in the Milindapañha - IV, 8.28. As part of his seemingly endless enumeration of the unpleasantness of life in its various forms, Buddhaghosa claims that 'ghosts know pain in great variety' (Vism. XVI, 43, p. 507).

116 One might argue that he takes the Hegelian approach and extends it.

117 Goodheart, E., Desire and Its Discontents. p. 175.

118 Dostoyevsky, F., Notes from the Underground. p. 19.

119 Goodheart, Eugene, Desire and its Discontents. p. 10.

120 Ibid., p. 11.

121 Not all see Notes from the Underground as quite so positive in its rejections of traditional views. Vladimir Nabokov sees the protagonist (who he calls 'the mouseman') as revelling in his despair: 'Unsatisfied desire, the burning thirst of parching revenge, hesitations - half-despair, half-faith - all this combines to form a strange morbid bliss for the humiliated subject. Mouseman's rebellion is based not upon a creative impulse but upon his being merely a moral misfit.' Nabokov, Vladimir, Lectures on Russian Literature. p. 117. Nabokov sees the nihilism of Notes from the Underground as too directionless - preferring the rebellion found in that great role-model for twentieth century fiction, Turgenev's Bazarov (from Fathers and Sons).

122 Goodheart, E., Desire and its Discontents. p. 11.

123 Ibid., Vol. 21. p. 179.

124 Cf. Beyond Good and Evil. Vol. 4, p. 3.

125 Nietzsche, Twilight of the Idols. Vol. 21, p. 80.

126 Nietzsche, Beyond Good and Evil. Vol. 19, p. 12.

127 Ibid., Vol. 19, p. 14.

128 Such an idea - of things as moral-in-themselves - being an anathema to Nietzsche. His most well known expression of this is in paragraph 108 (p. 49) of Beyond Good and Evil: 'There is no such thing as moral phenomena, but only a moral interpretation of phenomena.'

129 Nietzsche, Twilight of the Idols. Vol. 32, p. 85.

130 Ibid., 32, p. 85.

131 Bogard, W., http://csf.colorado.edu/mail/psn/jun96/0126.html, accessed 7/7/01.

132 Massumi, B., A User's Guide to Capitalism and Schizophrenia: Deviations from Deleuze and Guattari. p. 82.

133 Landau, J., Desiring-Machines. http://cs.art.rmit.edu.au/deleuzeguttarionary/d/ pages/desiring-machines.html [Accessed 01/05/2002].

134 Olkowski, D. E., 'Deleuze and Guttari: Flows of Desire and the Body.' In H. Silverman (Ed.), Philosophy and Desire. p. 187.

135 Ibid., p. 186.

136 Butler, J., Subjects of Desire. p. 5.

137 Ibid., p. 15.

138 Hegel, G. W. F., Phenomenology of Spirit. p. 109.

139 Ibid., p. 109.

140 Ibid., p. 111. 
141 Cited by Denise Levertov in the poem A Common Ground. In Penguin Modern Poets, 9.

142 Sartre, J.-P., Being and Nothingness. p. 615.

143 Ibid., p. 565.

144 Butler, J., Subjects of Desire. p. 95.

145 Ibid., p. 99.

146 Founded in 1875.

147 Speake, J. (Ed.), A Dictionary of Philosophy. p. 352.

148 Bowker, J. (Ed.), The Oxford Dictionary of World Religions. p. 970.

149 Blavatsky, H., Collected Writings, compiled by Boris de Zirkoff, VIII, p. 109, quoted: Esoteric Studies Guide website, http://www.geocities.com/katinka_hesselink/ will.htm [Accessed 7/7/01].

150 This notion of human life as dominated by a higher force, in a lower form of expression might remind us of Hindu notions of $\bar{l} l \bar{a}$ : the divine involved in some sense of sport or play (see SED, p. 903 for a full account of $l \bar{l} l \bar{a}$ ).

151 Quoted in Dollimore, J., Death, Desire \& Loss in Western Culture. p. 334, n. 5.

152 Although not of necessity - this is not the place for a life-style magazine discussion of whether one can have sex without 'romantic' emotions though, there are an ample number of cultural arenas for such topics.

153 Propertius, 'Athens, Refuge from Love.' In Musker, Ronald (Trans.), The Poems of Propertius. p. 159.

154 Mann, T., Essays of Three Decades, quoted in Goodheart, Eugene, Desire and its Discontent. p. 8.

155 If we treat Plato's 'appetite' and 'spirit' as one thing for the purpose of this discussion.

156 Quoted in Dollimore, J., Death, Desire \& Loss in Western Culture. p. 163 - although Kojève is describing desire here in a way closer to a hateful desire, the presence of the concept of assimilation is interesting - reflecting the effort of the subject to 'fill itself' via the object.

157 Sounding rather like The Heart Sutra.

158 See the three types of tanhā in Chapter 3.

159 Leavy, P., 'Grande, Decaf, Low Fat, Extra Dry Cappuccino: Postmodern Desire.' In A Journal of Media and Culture. Vol. 2, No. 5, 1999. http://www.uq.edu.au/mc/9907/ grande.html [Accessed 14/01/2002].

160 Heidegger has much in common in this respect with other existentialists examined, and I intend to say little else regarding him in this thesis.

161 Zimmerman, M. E., 'Ontical Craving versus Ontological Desire.' In B. Babich (Ed.), From Phenomenology to Thought, Errancy, and Desire. pp. 521-2.

\section{DESIRE IN NON-BUDDHIST INDIAN RELIGION}

1 Bhartrihari, 'The Hermit', verses 197-8. In Bhartrihari and Bilhana, The Hermit and the Love Thief. p. 101.

2 Lipner, J., 'Prolegomena.' In J. Lipner (Ed.), The Fruits of our Desiring: An Enquiry into the Ethics of the Bhagavadgīta. pp. iii-iv.

3 Solomon, R. C., Continental Philosophy Since 1750. p. 4.

4 This does not mean that all Indian religious thought offers a sophisticated appreciation of the subtleties and complexities of desire. Far from it, much devotional material presents a naïve and simplistic interpretation of desire - but it does address it.

5 This is discussed in the Introduction, but also see Chapters 1-3 of Gombrich's How Buddhism Began, where he claims that early Buddhist texts go as far as parodying the style and format of Brahmanic arguments. For example, we can read the Fire Sermon (Äditta-pariyāya sutta, S.IV, 19 \& Vin.I, 34-5) as structurally and conceptually related to the notion of the three fires of the householder in Hinduism. See Gombrich, p. $67 \mathrm{f}$ on this. 
6 See the discussion of terms for desire in Chapter 3.

7 She cites Book XII, Chapter 167, where Bhìma, one of the Pāndavas, praises kāma.

8 Although quite how she obtains such a position from the logicians of the Nyajya school of Hindu philosophy is unclear. The Nyāya approach seems based primarily on the removal of ignorance, via reasoning (be it through inference or analogy).

9 Biardeau, M., Hinduism: The Anthropology of a Civilization. p. 71.

10 In Buddhism avijja - ignorance - is the prime root of rebirth, see PED, p. 85. Furthermore, ignorance is even in the background of acts leading to positive karmic results. In the Buddhist view, the enlightened do not generate karmic results, and so all those who generate positive karmic consequences from their acts must still be in possession of avijja .

11 It has been suggested to me [by Dr Dermot Killingley, University of Newcastle upon Tyne (Retired)] that this is a poor translation and that 'desire came upon it in the beginning' is more accurate - desire as upsetting the balance - wanting as the first dualism of the monistic One. The second translation here seems more along these lines.

12 Unless otherwise indicated, the original Sanskrit term for 'desire' in the citations from Hindu texts in this chapter is käma (or kämayate where 'desire' is a verb). My thanks to Dr Dermot Killingley for his assistance with locating the Sanskrit terms used in this chapter.

13 Zaehner, R. C. (Trans.), Hindu Scriptures. p. 12.

14 O'Flaherty, W. (Trans.), The Rig Veda. p. 25.

15 Killingley, D., Käma. p. 19. (Unpublished paper, now included in The Hindu World (Ed.), Sushil Mittal, Routledge, 2004.)

16 Ibid., p. 6.

17 Ibid., p. 7.

18 Here 'desire' is from the root vaś. See SED, p. 929.

19 O'Flaherty, W. (Trans.), The Rig Veda. p. 117. O'Flaherty suggests that the seven sisters are 'the mares who are Agni's flames, here said to break out of the sweet butter poured on the fire' p. 118.

20 This idea has interesting resonances of the discussion, in the Introduction, of kusala as competence.

21 Both terms here are from the root käma (one is just käma, the other nikāma - it is unclear what distinction there is between the two).

22 Ibid., pp. 133-4.

23 Ibid., p. 28.

24 Ibid., p. 34.

25 Killingley, Dermot, Kāma. p. 9.

26 Her husband's semen.

27 Rg Veda 1.179.4, O'Flaherty, Wendy (Trans.), The Rig Veda. p. 251.

28 Atharva Veda, 10.9.2, 19. Bloomfield, Maurice (Trans.), Hymns of the Atharva-Veda, p. 223.

29 Killingley, D. Käma. p. 15. Akira Sadakata draws a connection between Kāma and Eros here - both using arrows to pierce the heart of the afflicted. He goes as far as to suggest that: 'So close are the parallels between the Greek and Hindu myths that one is led to believe that there must have been some direct Western influence.' Sadakata, Akira, Buddhist Cosmology: Philosophy and Origins. p. 135. I am not sure we need to concur with this view, but the similarity is striking.

30 Of the Atharva Veda.

31 Shende, H. J., The Religion and Philosophy of the Atharvaveda. p. 49.

32 Bihārī, The Satasī (Trans. K. P. Bahadur), verse 13, pp. 47-8.

33 Unless, as in the Atharva Veda it is seen as the first-born of the gods - how are we to make sense of this? Maybe the cosmological structure is such that once there is something rather than nothing - post-creation - desire is an ontological necessity. 
34 Although Māyā can have a wider range of meanings, see SED, p. 811.

35 Killingley, D., Käma. p. 20.

36 As a child, we may resent our desire for sweets, as it drives us to either frustration or conflict.

37 This story is reworked in the Mahābhārata, see O'Flaherty, Wendy, Śiva: The Erotic Ascetic. p. 55.

38 Zaehner, R. C. (Trans.), Hindu Scriptures. p. 27.

39 It is not wholly clear who is being discussed here, it may be Skambhá. The SED describes Skambhá as being a 'prop, support, buttress, fulcrum, the Fulcrum of the Universe'. p. 1257, and also sees it as related to Brahman. In this context it seems to be a semi-personified support of the universe.

40 Olivelle, P. (Trans.), Upanisads. p. 61.

41 This is worth briefly comparing to the idea that, in Buddhism, the 1st jhana (and those above it) is beyond the Käma-realm. Mind is unified on an object, and oblivious to the external world.

42 The atman.

43 Olivelle, P. (Trans.), Upanișads. p. 61.

44 Rg Veda 10.94.11. O'Flaherty, Wendy (Trans.), The Rig Veda p. 125. The terms 'thirst' and 'desire' here are translations of two adjectives (atrsita and atrṣnaj), both from the root trs (root of the Pali term tanhāa see next chapter).

45 The theme of desire as a feature of consciousness due to lack-of-being as the foundation of consciousness - our lack of Self (or Transcendental Ego/I in Sartre's terminology) as the root of a sense of 'lack' which drives all desires and makes us such insatiable wanters is important. It will be addressed with explicit relation to Buddhism in Chapter 3, and discussed comparatively later in the thesis in Chapter 5.

46 That is, depressant rather than stimulant narcotics.

47 Olivelle, P. (Trans.), Upanișads. p. 169.

48 While there is not time here, this may have Tantric echoes.

49 SED, p. 1126.

50 Killingley, D., Kāma. p. 10.

51 Chapple, Christopher, Karma and Creativity. p. 19.

52 Killingley, D., Käma. p. 10.

53 Which may remind us of the connection between desire and death discussed in Chapter 1. This will be returned to in Chapter 5.

54 Bṛhad-ăranyaka Upaniṣad 1.2.1; Olivelle, Patrick (Trans.), Upaniṣads. p. 7.

55 Ibid., p. 8.

56 This can be related to the ideas of death and finitude found in Chapter 1.

57 Chapple, Christopher, Karma and Creativity. p. 14.

58 This idea always reminds me of the 'One Ring' in Tolkien's Lord of The Rings.

59 Chāndogya Upanișad 4.10; Olivelle, Patrick (Trans.), Upaniṣads. p. 133.

60 Olivelle, P. (Trans.), Upanișads. p. 79.

61 Ibid., p. 84.

62 That $O m$ is a signifier of assent - and that assent is fulfilment.

63 Olivelle, P. (Trans.), Upanișads. p. 98.

64 Ibid., p. 289.

65 Here 'desire' is from the term icchati. This term is discussed in Chapter 3.

66 Zaehner, R. C. (Trans.), Hindu Scriptures. p. 228.

67 And we can recognise here why the Upanișads are often associated with the jñanamärga approach. This is looked at more fully when I come to the Bhagavad Gīta later in this chapter.

68 Citing, here, I think a verse from the Kaṭa Upaniṣad.

69 Olivelle, P. (Trans.), Upanișads. p. 185.

70 Ibid., p. 17. 
71 Ibid., p. 37.

72 'Desire' is here from the term eșan $\bar{a}-$ the Pali equivalent of which is discussed in Chapter 3.

73 Radhakrishnan (Trans.), The Principal Upanișads. p. 221.

74 From the Sanskrit icchati.

75 This is from Kämayate - while the following term translated as 'desire' is from eșanā.

76 Olivelle, P. (Trans.), Upanisads. pp. 67-8.

77 Radhakrishnan, Principal Upanișads. p. 273.

78 Olivelle, P. (Trans.), Upanișads. p. 65.

79 Chapple, C. Karma and Creativity. p. 17.

80 Celestial beings, who are later found in the epics of Hindu literature (and in the Pali Suttas), albeit with more developed characters.

81 Taittirīya Upanișad, 2.8; Olivelle, Patrick (Trans.), Upanișads. p. 189.

82 Śankarācārya, Eight Upaniṣads. Vol. 1, Swāmī Gambhīrānanda (Trans.), p. 371. We might also note that, in Buddhist thought, the first two jhannas result in great amounts of pitti (joy), though they lie beyond the realm of käma. In Buddhism, bliss increases as you go 'up' through heavens, before being finally transcended.

83 Niskāmatvam.

84 Bound to the cycle of rebirth.

85 Quoted (and translated) in Killingley, Dermot, Käma. p. 13.

86 Killingley, D., Kāma p. 12.

87 Sensual desire and spiritual exertion and yearning are hard to disentangle - both in the Hindu texts, and life itself - and this clouds the issue further. This may be part of the impetus for the development of the complex typology of desire in Buddhism.

88 Cited in Radhakrishnan, Principal Upanișads. p. 275. He seems here to be using a non-standard form of referring to the text in question, as in the standard Poona edition 11.174 has only 20 verses.

89 At Chändogya Upanisad 8, 1.4 there is something similar, built around the idea of the 'Fort of brahman' - in which are 'contained all desires'. Olivelle, Patrick (Trans.), Upanișads. p. 167.

90 Olivelle, P. (Trans.), Upanișads. pp. 123-4.

91 Käma and samkalpa.

92 Olivelle, P. (Trans.), Upanișads. p. 171.

93 Identified with the Self.

94 And that is all it would be, in the absence of textual support.

95 Olivelle, P. (Trans.), Upanișads. p. 175.

96 'Desire' here is from sprihā. The SED (p. 1269) gives this a rather eager form of desire - which we might consider more active than käma.

97 Zaehner, R. C. (Trans.), Hindu Scriptures. p. 222.

98 Olivelle, P. (Trans.), Upanișads. p. 252.

99 Śvetāśvatara Upaniṣad 1.11, Olivelle, Patrick (Trans.), Upaniṣads. p. 254.

100 Literally, 'one who desires' - 'hankers' is here from kāmayate - the verb form of käma.

101 Olivelle, P. (Trans.), Upanișads. p. 275.

102 Śankkarācārya, Eight Upaniṣads. Vol. 1, Swāmī Gambhīrānanda (Trans.), p. 154.

103 The goal of the Vedānta practitioner is clearly described in these terms by R. C. Zaehner when discussing the monist Vedāntin Śankara's reading of the Upaniṣads:

The barrier between subject and object seems magically to melt away, and experiencer, experience and the thing experienced seem to merge into one single whole: The One indwelling the human spirit realises its own identity with the same One which is the unchanging ground of the phenomenal world outside.

Zaehner, R. C., 'Introduction.' In R. C. Zaehner (Trans.),

Hindu Scriptures. pp. ix-X. 
104 Śan̉karācārya, Eight Upaniṣads. Vol. 1, Swāmī Gambhīrānanda (trans.), p. 22.

105 SED, p. 108.

106 Ibid.

107 So much so that some feel that it did so at the expense of other key notions. See 'Chapter IV: Retracing an Ancient Debate: How Insight Worsted Concentration in the Pali Canon' of Richard Gombrich's How Buddhism Began. p. 96ff.

108 Quoted in Lash, N., 'The Purification of Desire.' In J. Lipner (Ed.), The Fruits of Our Desiring. pp. 3-4.

109 Quoted in Lash, N., 'The Purification of Desire.' p. 4.

110 I am not going to allow myself to become drawn into the debates regarding the precise date of the Gitta , but it is certainly later than even fairly late Upanișads (such as the Śvetâśvatara Upaniṣad), and is also post-Buddhist.

111 Killingley, D., 'Enjoying the World: Desire (kāma) \& the Bhagavadgìtā.' In J. Lipner (Ed.), The Fruits of our Desiring: An Enquiry into the Ethics of the Bhagavadgitata. p. 67.

112 Ibid., p. 67.

113 Lash, N., 'The Purification of Desire.' pp. 1-2.

114 Zeahner, R. C. (Trans.), Hindu Scriptures. p. 251.

115 Ibid., p. 253.

116 Ibid., p. 254.

117 Killingley, D., 'Enjoying the World: Desire (kāma) \& the Bhagavadgītā.' p. 67. It is also worth noting that this reading of the Gìt $\bar{a}$ only became prominent during the early twentieth century in Bengal when the Gìt $\bar{a}$ achieved popularity, see p. 68 of Killingley's piece on this.

118 Ibid., p. 70.

119 See Section 7.11 of the Gìtā, as quoted below.

120 Killingley, D., 'Enjoying the World: Desire (kāma) \& the Bhagavadgītā.' p. 70.

121 Brockington, J., 'The Bhagavadgītā: Text and Context.' In J. Lipner (Ed.), The Fruits of our Desiring: An Enquiry into the Ethics of the Bhagavadgitta. p. 41.

122 Biardeau, M., Hinduism: The Anthropology of a Civilization. pp. 112-3.

123 Ibid., p. 113.

124 It is worth noting that some make a distinction between the bhakti of the Gita and later bhakti devotionalism. F. Hardy uses the term 'intellectual bhakti' for the earlier texts, and 'emotional bhakti' for the later forms. See Hardy, F., Viraha-bhakti: The Early History of Krșna Devotionalism in South India. pp. 25-9 for a discussion of this distinction.

125 Eliot, T. S., 'The Rock.' In T. S. Eliot, Selected Poems. p. 109.

126 Biardeau, M., Hinduism: The Anthropology of a Civilization. p. 113.

127 Zaehner, R. C. (Trans.), Hindu Scriptures. p. 280.

128 Ibid., p. 265.

129 Ibid.

130 Ibid., p. 266.

131 Although a vanquished enemy could potentially be put to use on behalf of the victor.

132 Presumably because it is such a hard life as a sannyāsin.

133 Biardeau, Madeleine, Hinduism: The Anthropology of a Civilization. p. 39.

134 From Aurobindo's Essays on the Gita, Sri Aurobindo Birth Centenary Library. Vol. 13, p. 103.

135 Williams, Y., 'A Divine Life on Earth: Aurobindo's Interpretation of the BhagavadGītā.' In Williams and McElvaney, Aurobindo and Zaehner on the Bhagavad-Gĩtā, p. 15.

136 Or at least not 'desire' in a narrow sense.

137 Killingley, D., Käma. p. 14.

138 This seems to be the case in Buddhism.

139 Quoted (and translated) in Killingley, D., Käma. p. 2. 
140 Biardeau, M., Hinduism: The Anthropology of a Civilization. p. 123.

141 What she means by this term is not clear, but it is possible that she is referring to material from renunciant traditions.

142 Biardeau, M., Hinduism: The Anthropology of a Civilization. pp. 123-4.

143 Many of the interesting distinctions between the ascetic and the erotic can be seen at work in the differing ways that the figure of Siva is understood. As Wendy O'Flaherty writes: 'The Siva of Brahmin philosophy is predominantly ascetic; the Siva of Tantric cult is predominantly sexual'. O'Flaherty, Wendy, Siva: The Erotic Ascetic. p. 6.

144 The seventh to tenth centuries (CE) were a particularly fruitful period for devotional bhakti poetry, filled with intense love and passion for the divine.

145 G. Flood gives it as twelfth century CE text, attributed to Sāndilya. See Flood, Gavin, An Introduction to Hinduism. p. 133.

146 Flood, G., An Introduction to Hinduism. p. 133.

147 Iyengar, B. K. S., Light on Yoga. p. 50.

148 Patañjāli's Eight-Limbed Yoga system.

149 Although Samkhya-yoga is distinct from this approach, being based upon coming to realise that the Self/Purusa is different from Prakrti.

150 Which can also be seen to have an epistemological component - coming to the knowledge that the atman and Brahman always were, in a metaphysical sense, identical anyway.

151 Lee Siegel notes that the connection between immersion in the Self and sexual union is present, albeit pre-eminently as an analogy rather than in the fuller forms worked out in some later thought, in the Brhad-äranyaka Upanișad (IV.iii.21), where he comments:

'The experience of absorption in the Self is compared to the experience of the suspension of ego-activity in the culmination of coition.'

Siegel, L., Sacred and Profane Dimensions of Love in Indian

Traditions as Exemplified in the Gìtagovinda of Jayadeva. p. 14.

152 And the yogin, although little more will be said at this stage regarding yoga.

153 Biardeau, M., Hinduism: The Anthropology of a Civilization. p. 124.

154 Ibid., p. 124.

155 The Kāma Sütra is a text usually attributed to Vātsyāyana, around 450 CE, but includes many later interpolations, and may also draw on the earlier texts. It forms part of a tradition of Kämaśästra texts, but is the most comprehensive and well-known.

156 Killingley, D., Käma. p. 3.

157 Vātsyāyana, Kāma-Sütra. 2.46-49 [Trans. Upadhyaya, S. C.], p. 74.

158 Ibid., p. 71.

159 Ibid., 2.11-13, p. 71.

160 Ibid., p. 1.

161 Ibid.

162 Vātsyāyana, Kāma-Sūtra [Trans. Upadhyaya, S. C.], p. 1.

163 Indeed, Killingley writes, of the use of kāma in Vedic cosmogony, that its usage is 'usually without an explicitly sexual meaning'. Killingley, D., Käma. p. 7.

164 Dasgupta, A History of Indian Philosophy. Vol. 1, p. 169.

165 See Dasgupta, p. 169f.

166 Presumably for fear of killing insects during shaving, as well as for more general ascetic reasons.

167 Dasgupta, A History of Indian Philosophy. Vol. 1, p. 173.

168 Ibid., Vol. 1, p. 174.

169 It would be unfair to call it 'fence-sitting'.

170 What Dasgupta calls 'collocations of qualities', p. 174.

171 Dasgupta, A History of Indian Philosophy. Vol. 1, p. 174. 
172 Dasgupta, A History of Indian Philosophy. Vol. 1, p. 174.

173 See Chapter 3 on cetanā.

174 Titze, K., Jainism: A Pictorial Guide to the Religion of Non-Violence. p. 20.

175 Ones who have attained high spiritual states.

176 Warren, Herbert, Jainism in Western Garb, as a Solution to the Life's Great Problems [From Notes of Talks and Lectures by Virchand R. Gandhi], p. 49.

177 Ibid., p. 50.

178 Jacobi, H. (Trans.), Jaina Sutras. p. 17.

179 Ibid., p. 61.

180 Ibid., p. 21.

181 Ibid.

182 PED, p. 115.

183 SED, p. 157

184 Jacobi, H. (Trans.), Jaina Sutras. p. 66.

185 Ibid., p. 262.

186 Ibid., p. 75. It is noteworthy that here we are given an acceptable kind of wish - the wish to destroy karma.

187 Jaini, P. S., The Jaina Path of Purification. p. 260.

188 Ibid., p. 260.

189 The notion of 'dust' adhering to the jī va puts me in mind of the use of the idea of 'dust' in Philip Pullman's His Dark Materials trilogy.

190 Sharma, A., A Jaina Perspective on the Philosophy of Religion. p. 129.

191 Jaini, P. S., The Jaina Path of Purification. p. 112.

192 Ibid., p. 112.

193 Ibid.

194 Ibid., p. 152.

195 Ibid., p. 144, n.19.

196 This is an interesting idea - maybe we can equate it with the desire for Brahman in the sense of Brahman as all-pervading and universal.

197 Quoted (and translated) in Killingley, D., Kāma. p. 15.

198 Ibid.

199 From samsāra.

200 Killingley, D., Kāma. p. 20.

201 Ibid.

202 Although theistic bhakti thought often balks at a final identification of the Self and God, we can see it as drawing us ever-closer to the divine, often in ways that have interesting parallels with much Christian thought.

203 Tantric Buddhism, which I do not address in this thesis, may be an interesting avenue for anyone wishing to explore this idea further.

\section{BUDDHISM AND DESIRE: THE VARIETIES OF DESIRE}

1 Dhp. 153-4. Translation from DP. p. 140:

Anekajāti samisāram sandhāvissam anibbisam

Gahakārakam gavesanto dukkhā jāti punappunam.

Gahakāraka dițtho'si puna geham na kāhasi

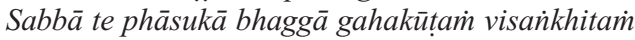

Visañkhāragatam cittam taṇhānam khayam ajjhagā.

Here tanh $\bar{a}$ is identified as the builder of the house (the body-mind we are currently existing as). Narada Thera identifies the rafters as the defilements (kilesa) and the ridge-pole as ignorance (avijjā), and wisdom shatters these, preventing further houses being built here by tanh $\bar{a}$. 
2 Due to the commonness of the term, and its usage in the previous chapter, I will continue with the Sanskrit ätman rather than use the Pali equivalent atta.

3 Once we enter Mahāyāna thought we can see desire in the context of 'skilful means', which may lead to a wider variety of ways in which it can be pragmatically employed.

4 Although notably the word kamma is still used for it.

5 The process whereby frustrated desires lead to dukkha will be addressed later.

6 Although this is not the case in some later Buddhist thought, such as Madhyamaka.

7 See Sn.1076 (Upasīva's Questions), where the tathägata is described as indescribable.

$8 \mathrm{Cf}$. The undetermined questions at S.IV, 373-400.

9 Although devotion and respect are still expressed to 'him'.

10 In the suttas we find numerous occasions where homage is paid to the Buddha. One of the most interesting is Vakkali. This bhikkhu, in the Khandasamyutta (S.III.120f), pays homage to the Buddha before the moment he takes his own life. Despite this apparent suicide, Vakkali is still said to have attained nibbāna. See n. 172 of CDB (p.1082) for an account of the commentary's explanation of this incident.

11 Along, of course, with the practising of this teaching - and by extension, that which this practice leads to.

12 The problems with 'views' (ditthi) will be examined more fully in Chapter 4.

13 This can also be seen as linked with the problems arising from the belief in a permanent Self - ' $I$ know the truth, you don't'.

14 M.I.160-75.

15 A Hindu being - a form of Brahmā, the most senior of Hindu devas.

16 This is rather a Christian-sounding set of attributes, but the devas lack of them, in a Buddhist understanding, does seem to quite well capture their lack of ultimate significance/status.

17 I had hoped to follow up some of the issues raised by this episode, particularly the idea which seems expressed in the sutta that the Buddha may have foreseen the possibility of his suffering mental weariness. However, due to considerations of space, I have had to leave these issues to be explored elsewhere.

18 This is not a full definition of dukkha, but rather an illustrative one.

19 Collins, S., Selfless Persons. p. 6.

20 We need not make too big a thing of this. We might see it as no more that asking an influential person for help - it is just in this case that the being asked is a deva, not a human.

21 As, indeed, are all the things that humans usually focus their desires upon.

22 D.III.207-271.

23 One presumes that this refers to beings residing in one of the hells that exist in the Buddhist view of the cosmos, though 'states of woe' could also apply to animals and petas.

24 D.III.218. Trans. LDB, p. 485.

santāvuso sattā paccupațthitakāmā, te paccupațthitesu kāmesu vasam vattenti, seyyathāpi manussā ekacce ca devā ekacce ca vinipatikā. Ayam pațamā kāmū papatti. Santāvuso, sattā nimmitakāmā, te nimminitvā nimminitvā kāmesu vasam vattenti, seyyathāpi devā nimmānaratī.

25 I am not going to get into a debate here about Nibbānic versus kammic Buddhism. First because it has limited relevance to the philosophical approach I am taking here, and second as it is not clear that such a distinction is that accurate or convincing. This distinction can be traced to M. Spiro's Buddhism, and Society.

26 At least in the Buddhist view. One's attitude to the àtman in Hinduism is radically altered by the identity of the atman with brahman. The 'I-am' belief which the anatta teaching is in opposition to has a radically different status in Buddhist thought.

27 Harvey, P., An Introduction to Buddhism. p. 52.

28 Kalupahana, D., Buddhist Philosophy: A Historical Analysis. p. 69. 
29 Of course, of the previous candidates, Buddhist Dhamma is the most difficult to reject - but we can see this, in a sense, as related to the desire for nibbāna, for that is what following the Dhamma will ultimately lead to. The problems with even correct views as objects of attachment is discussed in Chapter 4.

30 In addition to this, we can also place the joy we can allegedly generate on the Buddhist path in the positive column to balance the common presentation of Buddhism as negative or miserable in tone and content.

31 Whatever Nietzsche may say. For his description of Buddhism as a nihilistic religion, see Nietzsche, The Anti-Christ, Section 20, p. 129.

32 To attain a state of nibbāna, one must be free from all desire - even kusala forms. In an article on animitta (signless) mental states, Peter Harvey states that any mental state that has nibbāna as its object, if I read his argument correctly, is still an object-ful mind-state. The final attainment occurs when we have:

viñ̄āana, schooled so as not to be taken in by nimittas and worldly objects, does not even take nibbāna as object, but, objectless, transcends conditions and is the unconditioned.

Harvey, P., “ "Signless Meditations” in Pali Buddhism.' In Journal of the International Association of Buddhist Studies. Vol. 9, No. 1, 1986. p. 44.

33 She is referring here to Joanna Macy's 'Dependent co-arising: the distinctiveness of Buddhist ethics.' Journal of Religious Ethics, Vol. 7, No. 1, Spring 1979. pp. 38-52.

34 Burford, G., Desire, Death and Goodness. p. 6.

35 Conditioned phenomena are also subject to anatta, the third mark, but so is nibbanna, for it too does not constitute a Self.

36 I think this is what the whole of her book Desire, Death and Goodness is, to an extent, trying to do, even though she may not put it in quite these terms.

37 The world is, to adopt a more Buddhist tone, 'empty' of such objects.

38 If we take nibbanna as the beyond, that which lies outside the universe, which is its other. (Nibbāna is described as the 'stopping of the world'-loka-nirodha.) This position may be questioned by some Mahayāna thought, but nibbāna is certainly to be drawn in contrast to the world of the Self and gods.

39 While this Sanskrit term for 'own-nature' is frequently associated with Mahāyāna thought, it seems to capture, here, something of the Theravāda approach. Furthermore, Sarvāstivāda Buddhism did use the notion of svabhāva in explaining the nature of dhammas. Theravāda thought also uses the notion to examine dhammas, but in differing ways. See Harvey, P., An Introduction to Buddhism. p. 87. For more on svabhāva see SED, p. 1276.

40 Although Alexander Piatigorsky prefers, for Buddhist thought, the term 'metapsychology' - as he wishes to contrast the Abhidhamma approach with that of (presumably Western) reductionist approaches. See Piatigorsky, Alexander, The Buddhist Philosophy of Thought: Essays in Interpretation. p. 180.

41 The only Canonical account I can find of the 'Four Sights' is that at D.II.22-9, given with respect to the Buddha Vipassī. There appears to be no Canonical account with reference to Gotama Buddha.

42 Pubbe cāham bhikkave, etarahi ca dukkhañceva paññāpemi, dukkhassa ca nirodhaṃ.

43 See A.I.145-6 for a description of this.

44 Such as the desire to stay alive. If you do not know of death, you will not be in a position to desire to avoid it. However the notion that 'ignorance reduces desire' is not really found in Buddhism. Ignorance of certain things may mean that we do not desire them, but is unlikely to prevent us desiring something. 
45 We might see the compassion as coming later - the initial effect as being of shock, but I always feel the shock of these events in Gotama as going beyond 'self-interest'.

46 M.I.163. Trans. from MLD, p. 256.

Yamnnūnāham attanā jātidhammo samāno jātidhamme ādīnavam viditvā ajātam anuttaram yogakkhemam nibbānam pariyeseyyam, attanā jarādhammo samāno jarādhamme ādīnavam viditvā ajaram anuttarạ yogakkhemam nibbānam pariyeseyyam, attanā byādhidhammo samāno byādhidhamme ādīnavam viditvā abyādhim anuttaram yogakkhemam nibbānam ariyeseyyam, attanā maranadhammo samāno maraṇadhamme ādīnavam viditvā amatam anuttarạ yogakkhemam nibbānam pariyeseyyam, attanā sokadhammo samāno sokadhamme ādīnavam viditvā asokam anuttaram yogakkhemạ nibbānam pariyeseyyāa, attanā saṃkilesadhammo samāno saṃkilesadhamme ādīnavam viditvā asamkilițtham anuttarạ̣ yogakkhemam nibbänam pariyeseyyan.

47 Unless we take the view that all religious renunciants are inherently selfish - which is not a position I want to argue for here.

48 At M.I.163 the Buddha states 'Friend Kālāma, I want to lead the holy life in this Dhamma and Discipline'. (MLD, p. 256.)

49 M.I.166.

50 M.I.167.

So kho aham, bhikkhave, tattheva nisīdim- alamidạ̣ padhānāyāti.

51 Rhys Davids, Mrs, 'On the Will in Buddhism.' p. 48.

52 Though the goal, or stages nearing it, may involve much less of this mental exertion. The nirodha-samäpatti, the 'attainment of cessation', is a highly advanced meditative state, where: 'the mind totally shuts down, devoid of even subtle cognition or feeling, due to turning away from even the very refined peace of the formless level. In this state, the heart stops, but a residual metabolism keeps the body alive for up to seven days.' Harvey, P., An Introduction to Buddhism. p. 252. This state is one, however, that - as we shall see - requires much mental striving before we can hope to even near it.

53 Geiger, W. [Trans. Gosh, B.], Pali Language and Literature. p. 1.

54 Tattha yasmā rāgacaritassa kusalappavattisamaye saddhā balavatī hoti, rāgassa $\bar{a}$ sannagunattā. Trans. From PoP, p. 101.

55 Byāpādūpasamo etissā sampatti, sinehasambhavo vipatti. Trans. from PoP, p. 310. The term here for affection is sineha, which I discuss in note 95. A little later (at Vism. 318-9) we also see metta associated with greed (rāga), as its 'near enemy' (PoP, p. 311).

56 Such as at D.III.217.

57 Also at A.I.201, and It. 50.

58 Dhp 251.

Natthi rāgasamo aggi

natthi dosasamo gaho

Natthi mohasamaì jālam

natthi taṇhāsamā nadi.

59 PED, p. 567.

60 Ibid.

61 And given in the glossary of MLD, (p. 1372) for rāga. 
62 Perera, L. P. N., Sexuality in Ancient India: A Study Based on the Pali Vinayapitaka. p. 34.

63 SED, p. 872.

64 This theme is returned to in Chapter 5.

65 'Attachment' has been suggested to me, but this seems to strip the term of a little of its force - passion seems a fair middle-way between 'lust' and 'attachment' in capturing the right tone.

66 PED, p. 634.

67 As in the Dasuttara sutta D.III.290.

68 This is rather an awkward passage, and I rather rely on MLD (p. 455) in places.

69 Nānamoli and Bodhi presume, uncontroversially, that this is in the 'Pure Abodes', MLD, p. 455.

70 M.I.350.

No ce āsavānam khayam pāpuṇāti, teneva dhammarāgena tāya dhammanandiyā pañcannạ̣ orambhāgiyānam saṃyojanānam parikkhayā opapātiko hoti tattha parinibbāȳi anāvattidhammo tasmā lokā.

71 This may actually mean up to five more births, as there are five pure abodes.

72 See S.V.375-8 for a description of the various grades of noble persons such a non-returner and once-returner.

73 Although there is also the term patigha which is sometimes translated as 'ill-will'.

74 PED, p. 658.

75 LDB, p. 482.

76 It may be that kāma has a broader range of meaning in Sanskrit usage, and thus we find ideas that come within its scope accounted for by different terms in the Pali.

77 PED, p. 332. For an account of the dangers of dosa and it being contrasted with khanti patience - see Vism.295.

78 PED, p. 331. There can easily arise some confusion here, as the Sanskrit term dosha is equivalent to the Pali term dosā, both meaning 'evening' or 'night'. However a second meaning of dosha in Sanskrit is of 'fault, vice, deficiency, want' (SED, p. 498.). See SED, p. 498 and PED, p. 332.

79 SED, p. 507.

80 Which I would wish to clearly distinguish from a 'dull indifference'.

81 The PED, p. 543, gives moha as 'stupidity, dullness of mind and soul, delusion, bewilderment, infatuation'.

82 As it does in some sutta contexts.

83 SED, p. 905.

84 PED, p. 588.

85 De Silva, C. L. A., A Treatise on Buddhist Philosophy or Abhidhamma. p. 86.

86 At Vibh. 361-3.

87 Tattha katamāni tīni akusalamūlāni? Lobho, doso, moho. Tattha katamo lobho?

88 Sārāga is a relatively minor term given by the PED (p. 706) as 'affection, infatuation'. We can see its use in the Aggañña Sutta (D.III.88):

Tesam ativelam aññamañ̃am upanijjhāyatam sārāgo udapādi, pariḹaho kāyasmim okkami.

Excessively burning desire for each other arose, due to descending into a burning fever for their bodies.

Here sārāga is cast as part of a falling into gross sensuality. It is part of what seems to me a rather odd sutta, giving an account of the origins of varna, ostensibly given to show that Brahmins have no inherent superiority by birth. Perhaps the best way we 
can view sārāga is as something akin to 'lustful', and not so very far from $r \bar{a} g a$, to which it is etymologically linked.

89 The PED gives gedhā as 'greed' (PED, p. 253). This is sometimes found" in connection with sense pleasures, in the form kämesu gedhā, such as in the Appaka sutta (S.I.73-4), where beings that obtain some degree of worldly success are described as, all too often, kāmesu gedham àpajjanti - falling into greed for sense-pleasures (CDB gives this as 'yielding to sense-pleasures', p. 169).

When we find gedhā alone, such as in the Mahāsuññata Sutta (M.III.117), it is notable that it again occurs in combination with apajjati - to yield to, or fall into. We are told in this sutta of those who, when in seclusion (but, it would seem, following the wrong teacher), are visited by Brahmins and the like and fall back into worldly concerns. Antevāsūpaddavo, a disaster for the pupil, or what MLD calls a 'pupil's undoing' (MLD, p. 977.), comes about when they gedham àpajjati, āvattati bāhullāya (M.III.117) - 'fall into greed, and return to luxury'. Thus it seems that gedhā seems primarily concerned with the greed that can torment a renunciant - that which can upset one trying to make spiritual progress - and we saw in Chapter 2 the potential of desire as an 'upsetter'.

[*The PED claims this is a common connection - of kāmesu gedhā, but I found it to be quite rare, especially in the Suttas. A search of the entire CSCD edition (using kämesu gedh* [where '*' is a 'wildcard']) revealed only three instances, two here in the cited passage from the Appaka sutta, and one in the Cülaniddesa. Indeed, gedha is found in the Cülaniddesa and Mahāniddesa more than it is anywhere else.]

90 Pankka - literally 'mud, mire'. See PED, p. 382.

91 TBA (p. 470) translates janikā and sañjanan̄ as 'genetrix, fettering genetrix'. The obscure English term 'genetrix' means mother. The PED gives sañjanana as 'producing, progenetrix' (p. 670) and janikā is a form of janaka (see PED, p. 278). While janaka relates again to production, janika relates to the idea of a 'mother' again. In the context of this confusion, I have opted for a non-literal option that I hope conveys the appropriate feel.

92 See PED, p. 710, where this term is identified with desire - presumably as part of a binding up with lust, a net of lust.

93 Visattika is a fairly common term for desire, which the PED notes is 'almost always a syn. of tanhā' (PED, p. 639). So much is it a synonym of tanhā that it very often appears in close proximity:

\section{Yassa jālin̄̄ Visattikā tanhāa natthi kuhiñci netave.}

Tam buddham anantagocaram apadạ kena padena nessatha.

(Him in whom there is not that entangling, embroiling craving to lead (any life),

him the trackless Buddha of infinite range,- by which way will you lead him?)

Dhp. 180. Translation from DP, p. 162. (Also see Dhp. 335.)

It may have a little more of the sense of 'clinging' or 'attachment' than tanh $\bar{a}$, but there is little else to distinguish it.

94 This and the previous term both use vana, which is, as PED, p. 608 indicates, often also equated with vāna - also 'jungle': both have a strong figurative sense of desire. The image of desire as a jungle is powerful. Desire is something we become lost in, cannot find a way out of and, stretching the image a little, a jungle is something we need a guide to help us through to the farther side. There can also be as a relation here to the term Nirvāna - which we could take as 'absence of jungle' - to be enlightened is to have found a way out of the tangled jungle of desire.

95 Sineha has a primary meaning of 'viscous liquid, unctuous moisture' (PED, p. 710), and we can see here the idea of desire as 'sticky', echoing some of the Jain notions 
discussed in Chapter 2. Affection can be seen as moist in that we form bonds and attachments easily under its influence. There is also the term pema which indicates love and affection. In the Khaggavisāna sutta (Sn.41), we see pema as something to be avoided, as part of the fondness that leads to distress at the inevitable separation from those we are fond of. It is part of a series of verses that entreat us, for our own sakes, to 'wander alone'.

96 The term jappa $\bar{a}$ is a rarely used one, but a good illustration of a solidly akusala form of desire. The PED gives it as 'desire, lust, greed, attachment, hunger'. (PED, p. 279). We find jappā in an unambiguous setting at Sutta-Nipāta 945 (in the Attadanda Sutta, 15.11):

Gedham brūmi mahoghoti, ājavaṃ brūmi jappanaṃ; ārammaṇaṃ pakappanaṃ, kāmapañko duraccayo.

(I call this craving the great flood, I call this being absorbed in desire, attentive to sense-objects. The swamp of desire is hard to cross.)

Jappā here is something that is part of the great bog, or swamp of kāma. As such, it represents something to be overcome. We can also see jappā as negative, as akusala, at Sn.1033, jappābhilepanam brūmi, dukkhamassa mahabbhayam - 'The hunger of desire pollutes the world, and the source of great fear is the pain of suffering' (Trans. Snip. p. 118).

97 Pucchañjikatā is a rare term, and there seems to be some confusion over how to translate it. The PED, p. 463, notes this, and refers to the commentary to this passage. It seems that it may relate to anxiety about possession or non-possession of objects.

98 Sädhukamyatā is an interesting term. It is desire for sādhu (which the PED, p. 703, gives as good, virtuous, pious). TBA, p. 470, renders it as 'desire for the nicer'. It may be seen here in the context of being a form of lobha as a desire for a possibly good object - but wrongly held, possibly for the wrong reasons. Vibh.351 lists it as a form of tintina - a form of greedy desire, and it directly precedes a list relating to personal vanity. We might see it as a form of conceit or possibly pride.

99 TBA, p. 479, gives adhammarāgo as 'incestuous lust', and LDB, p. 401, (D.III.70) opts for 'incest' - drawing on commentarial readings of the term. It can be seen as inappropriately directed forms of lust.

100 Nikanti is another term for desire, possibly derived from kāma. The PED (p. 351) gives its derivation as from the Sanskrit nikānti based on $n i+k a m a t i$, and its meaning as 'desire, craving, longing for, wish'. Nikanti occurs primarily in commentarial texts. I give it as 'longing' here only to provide some vartiety in the translation.

101 In this context we can see dhammatanh $\bar{a}$ as craving not after the Dhamma in a general - positive - sense, but in the abhidhamma sense of dhammas.

102 Yo rāgo sārāgo anunayo anurodho nandī nandirāgo cittassa sārāgo icchā mucchā ajjhosānam gedho parigedho sañgo pan்ko ejā māyā janikā sañjanan̄i sibbin̄̄ jālin̄̄ saritā visattikā sotam visațā āyūhan $\bar{l}$ dutiya a panidhi bhavanetti vanam vanatho santhavo sineho apekkhā pațibandhu āsā āsīsanā àsīsitattam rūpāsā sadd̄āsā gandhāsā rasāsā photṭhabbāsā lābhāsā dhanāsā puttāsā jīvitāsā jappō abhijappā jappanā jappitattam loluppam loluppāyanā loluppāyitattam pucchañjikatā sādhukamyatā adhammarāgo visamalobho nikanti nikāmanā patthanā pihanā sampatthan $\bar{a}$

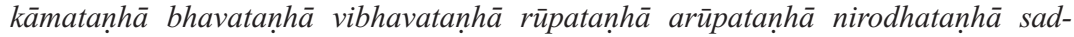

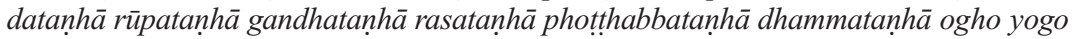
gantho upādānam āvaranam nīvaranam chadanam bandhanam upakkileso anusayo pariyuț̣̂ānam latā vevicchạ̣ dukkhamūlam dukkhanidānam dukkhappabhavo mārapāso mārabalisam māravisayo tạnhānadī taṇhājālam tạ̣hāgaddulam tạnhāsamuddo abhijjhà lobho akusalamūlạ̣-ayam vuccati "lobho". 
In translating this passage I make use of TBA (p. 470-1), but also try to offer my own view on certain terms. It is also worth noting that TBA mistranslates jappa as 'muttering' - due to confusion with the Sanskrit root jap (see SED, p. 411). Pali also contains words, such as japati and japana (see PED, p. 279), for muttering from this root - it is clear here that it is jappa as a form of desire that is intended.

103 PED, p. 118. ADP again concurs, offering 'wish, desire', p. 366.

104 Presumably, one from who desire has departed, i.e. one free from desire.

105 Dhp., 359. [24.26]:

Tịnadosāni khettāni icchādosā ayạ̣ pajā

Tasmā hi vigaticchesu dinnam hoti mahapphalam.

106 Muccati is a variation on Muñcati - to loosen, see PED, p. 535.

107 S. I.40.

'Kenassu bajjhat̄̄ loko, kissa vinayāya muccati;

kissassu vippahānena, sabbam chindati bandhanan'ti.

'Icchāya bajjhatī loko, icchāvinayāya muccati;

icchāya vippahānena, sabbam chindati bandhanan' $t i$.

108 It is worth noting here that loka can mean 'people' as well as 'world'. As the PED states (p. 586) of loka: 'Sometimes the term is applied collectively to the creatures inhabiting this or var. other worlds.' It may well be this sense that is intended in this context.

109 Harvey, P., The Selfless Mind. p. 79.

110 I also follow this by looking at two related terms. Even though they are not present in the lobha list it seems sensible to consider them together.

111 Though this seems rather odd, and I have not found it used in this sense myself at all.

112 PED, p. 403.

113 Means of spiritual progress.

114 Walshe (LDB, p. 514) translates atta-sammā-panidhi as 'perfect development of one's personality', treating atta as 'personality' and panidhi as 'development'. I use 'resolve' here to try and give a sense of the intentionality usually associated with panidhi.

115 D.III.276:

katame cattāro dhammā bahukārā? Cattāri cakkāni- patirūpadesavāso, sappurisūpanissayo, attasammāpanidhi, pubbe ca katapuñ̃̃atā. Ime cattāro dhammā bahukārā.

116 PED, p. 403.

117 The CSCD dictionary gives appanihita as 'free from longing or desire', which seems in accordance, loosely, with usage, if a little vague when compared to the PED account of panihita.

118 CDB, p. 1324.

119 Ibid., p. 1444, n.305.

120 Mil. 337, bhagavato samādhiratanam.

121 Mil. 337, suñ̃̃ato samādhi, animitto samādhi, appanihito samādhi.

122 At Vism. 657, we find the tīni vimokkhamukhāni - the three gateways to liberation.

123 A.I.8. avijjam bhecchati, vijjạ̣ uppādessati.

124 PED, p. 411.

125 An alternative translation might be 'endeavours', but 'striving' seems to capture something more active. 


\section{D.III.225:}

Cattāri padhānāni. Saṃvarapadhānạ̣ pahānapadhānạ̣ bhāvanāpadhānạ̣ anurakkhañāpadhānam. Anurakkhaṇa-guarding or preservation, is presumably, in this sense guarding of any kusala states that have been established.

127 PED, p. 609.

128 LDB, p. 348:

Katamo ca, bhikkhave, sammāvāyāmo? Idha, bhikkhave, bhikkhu anuppannānam pāpakānam akusalānam dhammānam anuppādāya chandạn janeti vāyamati vīriyam àrabhati cittam paggaṇhāti padahati.

129 PED, p. 382.

130 If we wish to draw back from this violent imagery (fighting, battle, etc. being a little too close to hatred for this context), we might say that a higher-order desire seeks to undermine a lower-order one.

131 Although, as we shall see, chanda can be positive.

132 For example, in the next chapter, we will see this approach used with respect to dealing with attachment to the body. We are encouraged to focus on its unpleasant aspects, to arouse in us a distaste for it as an object of clinging.

133 In addition to this, Buddhism claims that treading the Buddhist path generates joy and happiness en route to nibbāna.

134 Sometimes as apekhā.

135 PED, p. 55. The ADP definition is virtually identical, see p. 175.

136 Dhp. 345-6:

Na tạ̣ daḷam bandhanamāhu dhīrā, yadāyasam dārujapabbajañca

Sārattarattā maṇikuṇạlesu, puttesu dāresu ca yā apekkhā.

Etạn da!̣am bandhanmāhu dhīrā, ohārinam sithilam duppamuñcaṃ;

Eatmpi chetvāna paribbajanti, anapekkhino kāmasukhạ̣ pahāya.

137 PED, p. 55.

138 Ibid.

139 PED, p. 115.

140 A yakkha is a type of non-human being (amanussa).

141 As Walshe informs us (LDB, p. 579, n. 506), this indicates that Janavasabha is a 'Stream-Winner'. Janavasabha now desires to move on to the next spiritual level.

142 D.II.206:

Dīgharattam kho aham, bhante, avinipāto avinipātam sañjānāmi, āsā ca pana me santițthati sakadāgāmitāyā ti.

143 ADP, p. 354.

144 PED, p. 149.

145 The only remaining usage there is of the Pali language.

146 PED, p. 149. The idea of 'holding on to' in relation to forms of desire crops up in a number of terms - such as parāmāsa, given as 'touching, seizing, taking hold of' by the PED (p. 421).

147 PED, p. 63. ADP concurs, giving it as 'longing for, covetousness' (p. 195).

148 PED, p. 63.

149 Collins English Dictionary, Electronic Edition Version 1.5, 1992. 
150 M.III.49. Trans. from MLD, p. 917:

Idha, bhante, ekacco abhijjhālu hoti, yam tạ̣ parassa paravittūpakaranam tạ̣ abhijjhātà hoti- 'aho vata yam parassa tam mamassm' ti.

151 D.I.71:

So abhijjham loke pahāya vigatābhijjhena cetasā viharati, abhijjhāya cittạ̣ parisodheti.

152 For example, In LDB, p. 91. A more literal, but less evocative, translation would be 'The fruits of renunciation'.

153 PED, p. 274.

154 Gorkom, Nina van, Cetasikas. p. 113.

155 Vipāka is a (usually kammic) result. A chanda desire can, then, be seen as resulting from past acts. Kiriya (The PED, p. 215, gives kiriya as 'action, performance, deed') is here contrasted with vipāka, and in this context can be seen as chanda as an action itself - an occurrence of wanting not caused by past kamma (although clearly caused, in a paticca-samuppāda context). Chanda can arise in both these contexts.

156 Gorkom, Nina van, Cetasikas. p. 113.

157 De Silva, C. L. A., A Treatise on Buddhist Philosophy or Abhidhamma. p. 78.

158 We might relate this to the distinction that Stephen Batchelor establishes in Chapter 1 of his Alone With Others, where he discusses the differences between a life based in 'having' and one focused on developing the nature of 'being'.

159 SED, p. 404.

160 Ibid.

161 SED, p. 405.

162 S.II.144:

dhammadhātum pațicca uppajjati dhammasañ̃̃ā, dhammasaññạ pațicca uppajjati dhammasankappo, dhammasañkappam pațicca uppajjati dhammacchando, dhammacchandam pațicca uppajjati dhammaparilāho, dhammaparilāham paticca uppajjati dhammapariyesanā.

163 Vibh. 208f.

164 Vibh. 208.

165 TBA (p. 271f) uses 'wish' for chanda, which seems fair in the context, if a little vague. It does at least capture the sense of chanda as 'desire-to-do'.

166 Note here the kusala sense of käma in kattukamyatā - desire to act, here in a kusala manner.

167 Vibh. 208:

Tattha katamo chando? Yo chando chandikatā, kattukamyatā kusalo dhammacchando-ayam vuccati 'chando'

168 Walshe uses the phrase 'four roads to power', for example LDB, p. 215 (Trans. of D.II.213).

169 See D.I.77-8 and D. I.212 for a fuller description of these powers.

170 Translation taken from Gethin, Rupert, The Buddhist Path to Awakening, p. 81:

Idha bho bhikkhu chandasamādhippadhānasañkhārasamannāgatạ iddhipādam bhāveti.

Vìriyasamādhippadhānasañkhārasamannāgatam iddhipādam bhāveti.

Cittasamādhippadhānasañkhārasamannāgatam iddhipādam bhāveti.

Vìmaṃsāsamādhippadhānasañkhārasamannāgatạ iddhipādā̄ bhāveti. 
171 Gethin, R., The Buddhist Path to Awakening. p. 81f.

172 As TBA translates chanda.

173 Govinda, Lama Anagarika, The Psychological Attitude of Early Buddhist Philosophy. p. 119.

174 Batchelor, S., Alone With Others. p. 25.

175 The PED (p. 120) gives numerous references to injunctions not to use such powers in the presence of the laity.

176 Note also that desire can have this great power, in combination with the other aspects mentioned above, without the invocation of tanha as cosmological or metaphysical principle.

177 Sutta 15 of the Dìgha Nikāya.

178 Maurice Walshe prefers 'acquisition' (LDB, p. 224) - both this and 'getting' imply the attempt to possess an object of craving.

179 This is ambiguous, but the PED claims that in this context vinicchaya relates to 'deciding what to do with one's gains'. PED, p. 624.

180 The PED gives ajjhosāya as 'being tied to, hanging on, attached to' (p. 12). This seems a particularly strong form of attachment.

181 D.II.58-9:

Iti kho panetam, ānanda, vedanam paticca tanhā, tanham paticca pariyesanā, pariyesanam paticca lābho, lābham paticca vinicchayo, vinicchayam pațicca chandarāgo, chandarāgam pațicca ajjhosānam, ajjhosānam pațicca pariggaho, pariggaham pațicca macchariyam, macchariyam pațicca ärakkho.

182 To use the translation of Nārada and Bodhi. B. Bhikkhu (Ed.), A Comprehensive Manual of Abhidhamma. p. 77.

183 Notice here that viriy $\bar{a}$ - energy - is also one of the iddhipādās, and the bojjhangas are the factors of awakening.

184 These six, along with the seven universal ethically indeterminate cetasikas.

185 Vitakko, vicāro, adhimokkho, viriyam pīti, chando ca ti cha ime cetasikā pakinnakā nāma. Evam ete terasa cetasikā añ̃asamānati veditabbā.

186 The sabba-cittasādhäraña cetasikas.

187 Bhikkhu, B. (Ed.), A Comprehensive Manual of Abhidhamma. p. 81.

188 Gorkom, N. van, Cetasikas. p. 116-7.

189 It is in this context that a minor issue related to defining kusala as 'this which moves one towards nibbāna' arises. Such beings have attained it already - it can propel them no further, for they have gone 'all the way' on that path. Nonetheless, I would maintain that describing their chanda as 'skilful' is still justified (both philosophically and aesthetically).

190 SED, pp. 271-3.

191 Ibid., p. 271.

192 PED, p. 203. ADP gives two senses of käma, the second close to the PED quote here, but the first (ADP, p. 665) is closer to that in the SED: 'wish, desire; love; longing'. These, I feel, are just differing aspects of its usage, and represent no great deviance in interpretation.

193 PED, p. 203.

194 This might be read as meaning the objects of sensory desire - but also seems to have the sense of the desire for such things, as the objects in themselves seem incapable of being 'false'. We might see it as a negotiated position between the desire and desired, both of which are, in a sense, being characterised here.

195 M.II.261. I take the wording for mosadhammā directly from the PED, p. 543.

Bhagavā etad avoca- 'aniccā, bhikkhave, kāmā tucchā musā mosadhammā' 
196 See A.I.150, and Vism. 444. At Vism. 444, we find hearing's 'proximate cause' as 'primary elements born of kamma sourcing from desire to hear' (PoP, p. 444) This is hard to judge as to whether the use is wholly neutral. In the coming to be of embodied existence, we might judge that this desire to hear is a kamma-originating factor leading to the ear. To see it, in this context, as akusala seems rather harsh.

197 Nidd. I.1. The meaning of kilesa is discussed later in this chapter.

198 Or muccitu-kamyatā.

199 PoP, p. 688.

200 Ibid., Vism.665:

Tattha yakkhiniyā saddhị saṃvāso viya khandhānam 'aham mamā'ti gahaṇaṃ, susāne manussamamsam khādamānam disvā 'yakkhin̄̄ ayan'ti jānanam vìa khandhānạ̣ tilakkhaṇạ̣ disvā aniccādibhavajānanam, bhītakālo viya bhayatupaț̣̂̄ānạn, palāyitukāmatā viya muñcitukamyatā.

201 PED, p. 426.

202 Anderson, P., A Feminist Philosophy of Religion. p. 22.

203 Some might even argue that certain expressions of Buddhism have little time for the 'feminine' or female conceptions of spirituality, but I feel this to be a little too extreme a position. I base this on not just the existence of texts such as the Theri $\bar{l} \bar{a} t h \bar{a}$, but more widely on an interpretation of both the philosophical views of Buddhism, and many of its social manifestations (although I am aware that the latter area is a problematic one in this regard).

204 Often referred to as 'loving-kindness'.

205 Keown, Damien, The Nature of Buddhist Ethics. p. 226.

206 In MLD.

207 M.I.67, and also at S.III.54-5:

Anupādiyạ̣ na paritassati, aparitassam paccattaññeva parinibbāyati.

For a detailed discussion of this passage see Harvey, P., The Selfless Mind.p. 126 and pp. 202-05.

208 PED, p. 28.

209 LDB, p. 492.

210 MLD, p. 230. M.I.136:

so suṇāti tathāgatassa vā tathāgatasāvakassa vā sabbesạ̣ dițthiț̣̂ānādhiț̣̂ānapariyuțthānābhinivesānusayānạ̣ samugghātāya sabbasan்khārasamathāya sabbüpadhipaținissaggāya tạnhākkhayāya virāgāya nirodhāya nibbānāya dhammañ desentassa.

211 PED, p. 271.

212 Gethin, R., The Buddhist Path to Awakening. p. 196. He draws this directly from A.III.415: cetanāham bhikkhave kammam vadāmi. Cetayitvā kammam karoti kāyena vācāya manasā.

213 Collins, S., Selfless Persons. p. 201.

214 Keown, D., The Nature of Buddhist Ethics. p. 211. Though not all manifestations of cetanā will contain all of these, for surely only some will have pìt $i$ present.

215 As we shall see, chanda is quite a general term, and many of the minor terms for desire can be considered to be types of sub-types of chanda, if not quite synonyms. 
216 The term is given in a slightly varying set of ways in roman transliteration. In the PED, it is sankappa, in the CSCD as saikappa, and by others, for example, Rupert Gethin in his Buddhist Path to Awakening as samkappa.

217 PED, p. 662.

218 For example, W. F. Jayasuriya opts for 'Right Aspiration.' Jayasuriya, W. F., The Psychology and Philosophy of Buddhism. p. 167.

219 Vitakka - a form of thinking, given, in part, by the PED (p. 620) as 'initial application' - is quite close to the notion of cetana , and relates to applied thinking. Peter Harvey (The Selfless Mind, p. 111) gives vitakka as 'directed thought'.

220 Gethin, Rupert, The Buddhist Path to Awakening. pp. 193-4.

221 Although one might translate this as 'right-view', for although - as Chapter 4 discusses - there is a concern over 'views' in Buddhism, it may be argued that just as there may be 'right desire', surely 'right views' are to be encouraged, even if as only a staging post on the path to no views at all.

222 Or non-kāma.

223 D.II.312:

Katamo ca, bhikkhave, sammāsan்kappo? Nekkhammasan்kappo abyāpādasan்kappo avihimsā̄sañkappo, ayam vuccati bhikkhave, sammāsañkappo.

224 Vitakko - see above.

225 Vibh. para. 206.

Tattha katamo sammāsan்kappo? Yo takko vitakko...pe...sammāsañkappo maggañgạ̣ maggapariyāpannam-ayạ vuccati 'sammāsañkappo'.

226 PED, p. 377.

227 Gethin, R., The Buddhist Path to Awakening. p. 191.

228 Ibid., p. 192.

229 M.III.73:

Katamo ca, bhikkhave, micchāsñkappo? Kāmasañkappo, byāpādasan்kappo, vihimsāsan்kappo-ayam, bhikkhave, micchāsan்kappo.

230 As discussed, the mundane form consists of a reversal of the three factors found in micchä-sañkappa: kāma, byāpāda, and vihimsāa.

231 M.II.73, Translation from MLD, p. 936:

Yo kho, bhikkhave, ariyacittassa anāsavacittassa ariyamaggasamañgino ariyamaggạ̣ bhāvayato takko vitakko san்kappo appanā byappanā cetaso abhiniropanā vacīsañkhāro.

232 Along with is adjectival form esin, particularly in compounds, see PED, p. 162.

233 PED, p. 162.

234 D.III.216.

235 LDB, p. 484.

236 In $\mathrm{CDB}$, the preferred translation for esanā is 'search', which seems virtually equivalent with 'quest', in the context of the passage.

237 imāsam kho, bhikkhave, tissannam esanānam abhiñ̃āya ayam ariyo aț̣hangiko maggo bhāvetabbo. (S.V.54).

238 CDB, p. 1898.

239 Panna, D., and Sayadaw, U., Salient Articles on Buddha Dasena. On-line at http://nibbana.topcities.com/panadpa9.htm [Accessed 18/3/02]. 
240 For example, are Christians, or Muslims engaged in brahmacariyesanā?

241 Which is given as 'search, quest, inquiry', PED, p. 434. This seems to be used more widely and universally in this way, with none of the slight ambiguity surrounding esanā. The pari- pre-fix might be seen to demonstrate an active form of esana , which seems coherent with its use. We could see pariyesana as an active approach to the fulfilment of the 'wish' or 'longing' (as Robert Morrison [Nietzsche and Buddhism, p. 146] translates esanā), that is esanā.

242 M.I.161-3.

243 MLD, p. 254. M.I.162:

Katamā ca, bhikkhave, anariyā pariyesanā? Idha, bhikkhave, ekacco attana jatidhammo samāno jātidhammamyeva pariyesati.

The passage continues with ageing, sickness, death, sorrow and defilement in the same format, before then giving a further exposition on the nature of each of these unsuitable objects for 'searching'.

244 Pariyesan $\bar{a}$, undistinguished as either type, is sometimes seen in rather negative contexts, such as the detailed paticca-samuppāda descriptions in the Mahānidāna Sutta (D.II.58), where feeling is seen to lead to the seeking (pariyesanā), possession, attachment to, and possibly violent protection of possessions. See LDB, p. 224.

245 PED, p. 109.

246 For example, at Harvey, P., An Introduction to Buddhism. p. 107.

247 PED, p. 109.

248 Although use of the CSCD's search facilities reveal it as more common in commentarial literature.

249 CDB, p. 231. A note (CDB, n.636, p. 430) explains that adhesion is related to the 'cords of sensual pleasure'.

250 p. 213. D.II.36.

251 Walshe also feels the need for an explanatory note (LDB, n.290, p. 562), where he explains the term: 'Ālaya-rāma: delighting in a basis (i.e. something it can cling to).' However, I do not feel this greatly illuminates the meaning here.

252 PED, p. 226.

253 ADP, p. 727

254 PED, p. 216.

255 Ibid.

256 ADP, p. 693.

257 Ibid.

258 A. 1.10

'Pabhassaramidam, bhikkhave, cittam. Tañca kho āgantukehi upakkilesehi vippamuttan'ti.

259 As at Dhp.141, 393 and 394, where the matted hair of ascetics is dismissed as not necessarily a sign of holiness.

260 PED, p. 277.

261 In CDB (p. 101) this term is translated as 'this generation', but I give it here a wider temporal application.

262 ingha me tvaṃ, ānanda, pānīyam āhara, pipāsitosmi, ānanda, pivissāmī ti.

263 Boisvert, M., The Five Aggregates. p. 134.

264 LDB, p. 497. D.III.238:

Pañca cetasovinibandhā. Idhāvuso, bhikkhu kāmesu avītarāgo hoti avigatacchando avigatapemo avigatapipāso avigataparilāho avigatataṇho. 
265 The PED (p. 294) makes an interesting point here. It says, after mentioning Plato's Phaedo $(458,9)$, that 'neither the Greek nor the Indian thinker has thought it necessary to explain how this effect is produced.' This is an odd comment. It clearly cannot refer to how the state of tanhā is produced because it follows the statement above with a discussion of the production of tanha in the formula of paticcasamuppāda. It can only then refer to the issue of how a certain type of hunger-like desire is able to bring about the phenomenon of rebirth. Does Buddhism really not offer an account of this process - it, as I argue in Chapter 4, certainly seems to offer just such an account.

266 See SED, p. 454.

267 The PED gives sahagata (p. 700) as 'accompanying, connected with, concomitant' although in this famous verse the exact sense which is intended does not seem immediately obvious.

268 D.II.308:

Katamañ ca, bhikkhave, dukkha-samudayam ariya-saccam??

Yāyam tanh $\bar{a}$ ponobhavikā nandi-rāga-sahagatā tatra tatrābhinandin̄i, seyyathī dạn kāma-tanhā bhava-taṇhā vibhava-taṇhā.

269 The place of tanhā in paticca-samuppāda will be more fully explored in Chapter 4 .

270 Robert Morrison, whose views will be addressed in more detail shortly, speculates about why this might be the case - arguing that its poetic tone and figurative derivation makes it less suited to be the abstraction and listing of Abhidhamma material. See Morrison, Robert G., 'Two Cheers for Tanhā', in Contemporary Buddhism. Vol. 2, No. 1, 2001. p. 99.

271 Translation from Ud-It, p. 161. It. 15:

'Taṇhādutiyo puriso, dīghamaddhāna saṃsaram!; itthabhāvaññathābhāvam samsāram nātivattati.

Etamādīnavam ñatvā, taāham dukkhassa sambhavam

vìtataṇho anädāno, sato bhikkhu paribbaje'ti.

272 For example, at S.V.86, where the bojjhangas (factors of enlightenment) are given as leading to the destruction of tanhā. At Dhp. 337 we are exhorted to dig up the root of tanh $\bar{a}$ - this whole section of the Dhammapada - the Tanh $\bar{a}$ vagga reads as a polemic against tanh $\bar{a}$.

273 This is a view which gets worked out in detail in commentarial literature, but which I believe is fairly implicit in the suttas.

274 These wrong views - of the Self as eternal, or being annihilated at death - are listed amongst the 62 kinds of wrong views at D.I.13 in the Brahmajāla Sutta.

275 Boisvert, M., The Five Aggregates. p. 134.

276 Keown, D., The Nature of Buddhist Ethics. p. 65. He represents this with a diagram, as shown here:

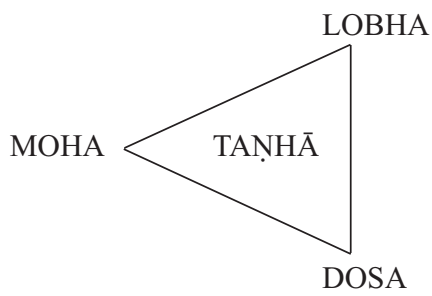


277 Or at least more generally - it is equated with so many terms, as we saw earlier.

278 See PED, p. 543 on moha. In any case, ignorance is not itself part of tanha $\bar{a}$, although it can clearly be seen to condition it.

279 Here along with byāpādo - 'ill-will, malevolence', PED, p. 492.

280 M.II. 258, Translation from MLD, p. 866:

tạnhā kho sallam samaṇena vuttam, avijjāvisadoso chandarāgabyāpādena ruppati.

281 Faure, B., The Red Thread: Buddhist Approaches to Sexuality. p. 4.

282 Ibid., p. 11.

283 Quoted by Faure, ibid., p. 15.

284 The Nettipakarana is considered later than much in the Canon, and often as paraCanonical.

285 Tattha tạ̣hā duvidhā kusalāpi akusalāpi. Akusalā saṃsāragāmin̄̄, kusalā apacayagāmin̄̄ pahānatanhhā.

Presumably the diminution or 'falling away' (see PED, p. 50) indicated by apacaya's use is a reduction in states leading back to samsāra.

286 Although as noted, the abhidhamma sees it primarily as one of type - but with degrees within the typological distinction.

287 D.II.216:

Aparāpi tisso tanh $\bar{a}-$ rūpatanh $\bar{a}$, arūpatanh $\bar{a}$, nirodhatanhā .

288 Matthews, B., Craving and Salvation. p. 79.

289 Ibid., p. 79, quoting Rhys Davids, T. W., Dialogues of the Buddha. Vol. III, p. 209.

290 Vibh. 366:

Tattha katamā nirodhatanhāe? Ucchedadițthisahagato rāgo sārāgo cittassa sārāgo- ayam. Vuccati 'nirodhatanhhā'.

291 Vibh. 365:

Tattha katamā vibhavatanhā?? Ucchedadițthisahagato rāgo sārāgo cittassa sārāgo-ayam Vuccati 'vibhavatanh à'.

292 Found in Johansson, R., The Dynamic Psychology of Early Buddhism. p. 103.

293 Matthews, B., Craving and Salvation. p. 79.

$294 \mathrm{He}$ does not say which others he is referring to.

295 Matthews, B., Craving and Salvation. pp. 79-80.

296 Ibid., p. 80.

297 A.II.145. Trans. from NDB, pp. 110-1: Note the punctuation in this version taken from the Burmese CSCD version of the Pali:

āhārasasbhūto ayaṃ, bhagini, kāyo āhāram nissāya. Āhāro pahātabbo. Taṇhāsambhūto ayạ̣, bhagini, kāyo tạnhām nissāya. Taṇhā pahātabbāa.

298 A.II.146, Translation from NDB, p. 111:

Tassa evam hoti- 'kudāssu nāma ahampi āsavānam khayā anāsavam

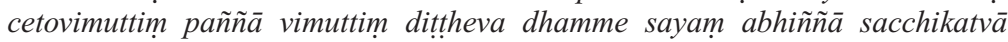


upasampajja viharissāmì'ti! So aparena sama yena taṇhạ̣ nissāya tạ̣hạ̣ pajahati. 'Taṇhāsambhūto ayam, bhagini, kāyo tạ̣hạ̣ nissāya. Taṇhā pahātabbā'ti.

299 And is certainly less akusala than many forms of tanha directed at less noble objects.

300 Matthews, B., Craving and Salvation. p. 81. His citation comes from Jayatilleke, K. N., Buddhism and Peace. p. 12.

301 Matthews gives a different type of reference to A., but does not give enough detail to comment on it here, but he names the sutta, and there is no doubt that he is referring to the sutta at A.II.145.

302 Matthews, B., Craving and Salvation. p. 81.

303 Originally published (Western Buddhist Review, 1997) as Three Cheers for Tanhā

304 Morrison, R. G., 'Two Cheers for Tanhāa.' In Contemporary Buddhism. Vol. 2, No. 1, 2001. p. 99.

305 Ibid., p. $99-100$

306 I might call it 'an engine of creation', but I think in the way Morrison views it that the definitive pronoun is more appropriate.

307 Which will be more fully discussed in the next chapter.

308 Morrison, R. G., 'Two Cheers for Tanhā'. p. 101.

309 Morrison translates koti here as 'beginning'.

310 Morrison, R. G., 'Two Cheers for Tanhā'. p. 101.

311 Ibid., p. 101

312 Ibid.

313 Although I use it here differently, I take, in part, the being/having distinction from Batchelor, Stephen, Alone With Others. p. 25f.

314 Morrison, R. G., 'Two Cheers for Tanhā'. p. 101.

315 The Vibhanga passages cited earlier also seem to support the way I use bhava and vibhava-tanhā here.

316 Where lay followers are given a teaching appropriate to their circumstances and spiritual development, while monks and nuns receive a 'higher' teaching.

317 The most striking of these occurs in the story of Nanda (a paternal half-brother of the Buddha). Nanda is, in Ud.3.2, considering disrobing due to a preoccupation with a beautiful girl he knew. The Buddha offers Nanda 'Five hundred pinkfooted nymphs' (Ud-It, p. 37) if he will remain living the monastic life under the Buddha. Nanda promptly agrees, but later, upon realising nibbāna, releases the Buddha from his promise to supply the nymphs. There are all kinds of issues raised by this episode, but primarily it shows not only the pedagogic flexibility of the Buddha, but also how the notion of relative, as well as absolute, conceptions of the good are accommodated in Buddhist thought.

318 Even though some aspect of tanha $\bar{a}$ is seen to persist until Arahatship.

319 At least for our own liberation. Work on the behalf of others can be seen to continue in the enlightened - unless they are a Pacceka Buddha, who does not teach.

320 At least with respect to the Vedic view, and although I take on board the critique offered by Richard Gombrich, where he claims that what the Buddha argues against is the Upanișadic view of the Self, which is 'something very few westerners have ever believed in and most have never heard of' (Gombrich, R., How Buddhism Began. p. 16), I still think that the anatta teaching rules out much contained in certain Western views of Selfhood. These issues will be, to an extent, returned to in Chapter 5.

321 Or believe that we are without - as is the case for much of the discussion in Chapter 2. Desire as 'lack' was discussed in Chapter 2, and will be returned to in Chapter 5. 


\section{BUDDHISM AND DESIRE: THE DYNAMICS OF \\ DESIRE}

1 Ud, 1.3. Bodhi Sutta. Trans. from Ud-It p. 15:

Yadā have pātubhavanti dhammā, àtāpino jhāyato brāhmanassa; vidhūpayạ̣ tițthati mārasenam, sūriyova, obhäsayamantalikkhan.

2 It would be too judgemental, at this stage, to describe it as being hindered by this.

3 I had also hoped to examine the status of the mind-body relationship in a Tathägata. This would have been primarily explored via a consideration of the Buddha's reported initial reluctance to teach the Dhamma. However, constrictions of space have not enabled me to do so here.

4 After our examination of the Upanișads, perhaps this is less surprising than it might otherwise be. The Upanișads are well-known for viewing knowledge as salvific, and also see this process as caught up with the overcoming of desire.

5 Although, as Nānamoli and Bodhi point out (p. 1222, n. 341 of MLD), the actual statement is not found as said by the Buddha anywhere in the Canon. Even with the aid of modern technology (i.e. CD-ROMs) I have been unable to locate this statement in any discourse directly delivered by the Buddha.

6 Here passati is rendered as 'to see', but 'to understand' or 'to have insight into' are equally good terms. Here, for once, I have opted for conciseness.

7 M.I.190-1:

yo pațiccasamuppādam passati so dhammam passati; yo dhammam passati so pamiccasamuppādam passatīti.

8 Translation from MLD, p. 355:

imasmị̣ sati idam hoti, imassuppādā idam uppajjati.

9 M.I.264. Translation from MLD, p. 357:

imasmị asati idam na hoti, imassa nirodhā idam nirujjhati.

10 Or maybe 'experience', though this is not the place to get into a debate as to whether 'reality' and 'experience' need distinguishing.

11 If we were to be pedantic, we might take issue with this aspect of the PED definition. In some Abhidhamma analysis the condition and the conditioned can be seen as occurring not sequentially, in temporal terms, but simultaneously.

12 PED, p. 394.

13 Kalupahana, D. J., Buddhist Philosophy, A Historical Analysis. p. 26.

14 The Buddhist approach contains more spiritual areas, albeit arising due to conditions, and the view of the mind is developed in very different ways. Furthermore, paticca-samuppāda is explained predominantly in terms of mental, rather than physical phenomena.

15 As at M.I.262, above.

16 Harvey, P., An Introduction to Buddhism. pp. 54-5.

17 Vism. 542, Translation from PoP. p. 553:

Ekato hi kāranato na idha kiñci ekam phalamatthi, na anekam. nāpi anekehi kāranehi ekam. 
18 Vism. 542, Translation from PoP. p. 553:

Bhagavā hi katthaci padhānattā, katthaci pākațattā, katthaci asādhāranattā desanāvilāsassa ca veneyyānañca anurūpato ekameva hetum vā phalam vā dīpeti.

19 Kalupahana, D., Buddhist Philosophy, A Historical Analysis. p. 26.

20 M.I.261:

Iti kho, bhikkhave, avijjāpaccayā san்khārāa, san்khārapaccayā viññānam, viññānapaccayā nāmarūpam, nāmarūpapaccayā saḷayatanam, salāyatanapac-

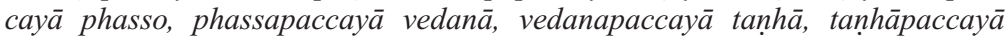
upādānam, upādānapaccayā bhavo, bhavapaccay $\bar{a}$ jāti, jātipaccayā jarā̄y maranạ̣ sokaparidevadukkhadomanassupāyāsā sambhavanti. Evametassa kevalassa dukkhakkhandhassa samudayo hoti.

21 D.II.62-3, Translation from LDB, p. 226:

“"Viññānapaccayā nāmarūpan”ti iti kho panetạn vuttam, tadānanda, imināpetam pariyāyena veditabbam, yathā viñ̃ānnapaccayā nāmarūpam. Viñ̃ānañca hi, ānanda, mātukucchismim na okkamissatha, api nu kho nāmarūpam mātukucchismiā samuccissathà 'ti?

'No hetam, bhante'.

22 For an account of the arising of human life, from conception to adulthood, see the Mahātanhāsankhaha Sutta, at M.I.266-7.

23 Kalupahana, D., Buddhist Philosophy, A Historical Analysis. p. 52.

24 Walshe, in the notes to LDB, comments on this term: 'Viññana-sota: a rare expression which seems to equate with bhavanga, the (mainly) commentarial term for the "life-continuum".' (LDB, p. 606). While, as he makes clear here, there is in the commentaries further development of the idea of what links lives together, viñ̃anna plays a key role - albeit not perhaps as obviously as Kalupahana claims.

25 The process of conception is discussed at M.I.265-7 in the Mahātaṇhāsankhaya sutta.

26 Translation from LDB, p. 226.

'Viñnānañca hi, ānanda, daharasseva sato vocchijjissatha kumārakassa

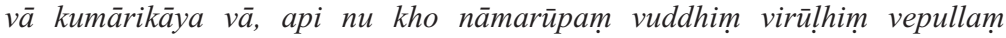
àpajjissathā'ti?

'No hetam, bhante'.

'Tasmātihānanda, eseva hetu etạn nidānam esa samudayo esa paccayo nāmarūpassa-yadidạn viñ̃̄ānam’’.

27 His translation of viñ̃āna.

28 Harvey, P., The Selfless Mind. p. 130. He gives a very detailed account here of the relation of viññana to the various factors of nämarūpa.

29 A previous Buddha, before the historical Buddha - Gotama.

30 D.II.34:

Atha kho, bhikkhave, vipassissa bodhisattassa etadahosi-

'kimhi nu kho asati viñ̃̃annam na hoti, kissa nirodhā viññannanirodho'ti?

atha kho, bhikkhave, vipassissa bodhisattassa yoniso manasikārā ahu pañ̃̄āya abhisamayo- 'nāmarūpe kho asati viñnānạm na hoti, nāmarūpanirodhā viññānanirodho'ti. 
31 Harvey, P., The Selfless Mind. p. 118.

32 Ibid.

33 M.III.285, Translaiton from MLD, p. 1134:

dukkhāya vedanāya phutțho samāno socati kilamati paridevati urattālị̣ kandati sammoham āpajjati. tassa pațighānusayo anuseti.

34 D.II.306.

35 While M.III.285 does not use vibhava-tanhā for aversion, rather using patighāno, we can see clearly the same kind of response as being involved.

36 Another way to look at this is to see how 'feeling' leads to cognitive activity in the understanding of the perceptual process. We can see this discussed at M.I.111-2, where we can see that 'sañjānāti', cognition, arises from vedanā. There seems scope here for the notion that vedanā does not have to, always, lead to tanhā. Either by intervening in the stages that sit between the two, or via altering other conditioning factors (such as the undermining of avijjā), the arising of tanh $\bar{a}$ in response to vedan $\bar{a}$ can be prevented. In A.IV.146-7, cognition and volition (cetanā) are implied as sitting between the arising of vedanā and tanhā. See Harvey, P., The Selfless Mind. p. 139.

37 Govinda, Lama Anagarika, The Psychological Attitude of Early Buddhist Philosophy. p. 55.

38 See Ayer, A. J., The Foundations of Empirical Knowledge. p. 58f.

39 Although this makes it more like the kinds of things that mano, as a sense, has as its objects - dhammas.

40 Harvey, P., An Introduction to Buddhism. p. 59. Also see Harvey, P., The Selfless Mind, Chapter 5. We can see this in the suttas at S.IV.95, where the manner in which we construct the world of our lived experience is explained. Interestingly this is a more detailed clarification of the passages on the end of the 'world' that I discuss in the final chapter.

41 MLD, p. 1186.

42 What would an external state of mind be like, one wonders?

43 MLD, p. 1187.

44 Or at the very least conditions the consciousness-event-series to arise as earconsciousness.

45 Matthews, B., Craving and Salvation. p. 25.

46 Although he is right in claiming that in M.I.293 (the Mahāvedalla Sutta), "perception and feeling come before viñ̃ăna' (Ibid., p. 25), more interesting is the claim in the Mahāvedalla Sutta that feeling, perception and consciousness (vedanā, sañ $\tilde{a}$ and viñ̃āna) arise not so much sequentially but intertwined together. M.I.293 states:

'feeling, perception and consciousness, friend - these states are conjoined, not disjoined'.

(Trans. from MLD, p. 389; Yā cāvuso, vedanā yā ca saññā yañca viñ̃̄annamime dhammā samsatțhā, no visamsațthā.)

The text goes on to state that they cannot be separated out from each other and that it is impossible to describe the difference between them. This demonstrates what I was saying earlier with regard to the intertwined nature of paticca-samuppāda, and the difficulty of extracting linear sequential understandings of cause-and-effect from it.

47 Were I being pedantic, I could suggest that there is no-thing that has the experience (in the light of anatta), and could rather ask where the experience occurs within the Buddhist model.

48 Matthews, B., Craving and Salvation. p. 39.

49 In the sense of viewing mano as part of the overall experience of consciousness. 
50 Translation from MLD, p. 284; M.I.191:

Yato ca kho, āvuso, ajjhattiko ceva mano aparibhinno hoti, bāhirā ca dhammā āpātham āgacchanti, tajjo ca samannāhāro hoti, evam tajjassa viñ̃̄ānabhā̄y gassa pātubhāvo hoti.

51 Dhp 233:

Manopakopațakkheyya, manasā sațuto siyā; Manoduccaritat hitvā, manasā sucaritat care.

52 Here we find the phrase manasā ditthigatāni cintayanto - 'thinking in the mind of differing views'. Norman, in his translation, gives this as 'thinking over views in your mind'. Norman (Trans.), The Group of Discourses. Vol. II, p. 97.

53 Johansson, R. E. A., 'Citta, Mano, Viñññāṇa - a Psychosemantic Investigation.' In University of Ceylon Review. Vol. 23, 1965. pp.165-215, p. 183.

54 Ibid.

55 I know that this is not the only time I say this in this chapter, but the area is far too large, and while fascinating, would just be an indulgence given the current context.

56 Cousins, Lance, 'The Patthāna and the Development of the Theravādin Abhidhamma', in JPTS. Vol. IX, 1981. p. 30.

57 Johansson, R. E. A., 'Citta, Mano, Vinnana - a Psychosemantic Investigation.' p. 185. The term manasikāro - more literally 'work of mind', 'attention' - is interesting. The presence of mano within it indicates the role of mano in the turning of one's mind to any kind of object of consciousness - internal or external.

58 Ibid., p. 187.

59 Translation from TBA, p. 107:

Cha dhātuyo- pathavīdhātu, āpodhātu, tejodhātu, vāyodhātu, ākāsadhātu, viñ̄āna

60 One of eighteen dhätus - as found in the Suttas: there are six corresponding to the six senses (including mano), six corresponding to the objects of these senses, and six corresponding to the six related consciousness. The first twelve can be seen as corresponding to the twelve ayatanas. This term, ayyatana, can be seen to represent the 'sphere of perception' (PED, p. 105) - the world of senses and their objects.

61 Translation from TBA, p. 114. Vibh. 88.

\begin{abstract}
Tattha katamā manodhātu? Cakkhuviñ̃̄ānadhātuyā uppajjitvā niruddhasamanantarā uppajjati cittạ mano mānasam hadayam pạ̣daram mano manāyatanam manindriyam viñ̃ānam viñ̃̃ānakkhandho tajjāmanodhätu.
\end{abstract}

62 This can be seen as the basis of the later Theravāda notion of citta-vithi - the process of consciousness, which is found in Vism., and which Harvey claims (Harvey, P., The Selfless Mind. p. 252) is implicit with the Abhidhamma. This process of consciousness becomes part of a complex explanation of the manner in which perception occurs. As such, while interesting, I follow it no further here.

63 While five-sense-based forms of vedana may not be seen as subjective in this way, if we see mano as an integrator of what arises via the physical sense, we can see all experience as, in one way or another, being mediated via the mano-consciousness process.

64 We might describe this ignorance as twofold. On one hand there is the misperception of reality, partly due to negative conditioning factors. Second there is what we might term 'ignor-ance' - the choosing to ignore that which is difficult or overly challenging to the way we select to view the world. 
65 Matthews, B., Craving and Salvation. p. 34.

66 We might be more precise, and claim that in some senses, tanh $\bar{a}$ is spark, while upādana is the up-taking of the fuel.

67 To maintain this image, we might describe avijja as the oxygen - the necessary context for the fire.

68 Although this only applies to one of the forms of petas.

69 Pitr.

70 See PED, p. 472.

71 Mil. 294.

72 QKM, Vol. II, p. 151.

73 Harvey equates nama-rūpa with the term 'sentient body', but does not include viñiaña in it. See Harvey, P., The Selfless Mind. p. 119.

74 One issue that clearly relates to this is whether or not Theravāda Buddhism can coherently accept a between-lives state. See Harvey, P., 'The Between-lives State in the Pāli Suttas.' In P. Connolly, (Ed.), Perspectives on Indian Religions - Papers in Honour of Karol Werner. Also see Chapter 6 of his The Selfless Mind.

75 I follow Ñānamoli and Bodhi's translation of uttari manussadhammā here (see MLD, p. 340), and take it to refer to the achievement of jhäna states.

76 M.I.246:

na kho panāham imāya kațukāya dukkarakārikāya adhigacchāmi uttari manussadhammā alamariyañānadassanavisesaṃ. siyā nu kho añ̃no maggo bodhāyā?

77 It is clear that in Buddhist thought, pleasure is not inherently wicked; for example the first jhāna is described as blissful, though beyond kāma.

78 A study of meditation practice will, however, reveal that the body must be mastered and 'tamed' or 'quietened' by the practitioner. See M.I.56 on this approach, where breathing practice is used to still the body.

79 M.I.58:

ayampi kho kāyo evamihammo evaṃbhāvī evam-anatīto.

80 For example in Chapter 6, Asubha-kammatțhāna-niddesa - foulness as a subject of meditation. I think it is not hard to concur with Peter Harvey's view that this will be 'a sure way of developing disenchantment with the body'. Harvey, P., An Introduction to Buddhism. p. 247.

81 Although it is also used as a term for 'visual forms'.

82 PED, p. 574.

83 For an analysis of these factors, see Vism. 364-6.

84 See Vism. 444, also Vibh. 12-5.

85 This distinction is not wholly absent in the Suttas, but is made explicit and elaborated upon in the Abhidhamma.

86 Gethin, R., The Buddhist Path to Awakening. p. 56.

87 As the PED (p. 350) states: 'nāma as metaphysical term is opposed to rūpa, and compromises the 4 immaterial factors of an individual.' However, it has been noted above that the Suttas do not include viñ̃anna within the scope of näma. The abhidhamma does include viñ̃āna in näma. Peter Harvey's The Selfless Mind discusses this at some length, as indicated above.

88 The four non-rüpa khandhas.

89 PED, p. 350.

90 By which, in the context he writes, he means the Pali Canon.

91 Kalupahana, D., Buddhist Philosophy, A Historical Analysis. p. 52.

92 And presumably, to an extent, in other sentient beings.

93 Which the Burmese CSCD places within the Canon as part of the Khuddaka nikaya. 
94 olarika - coarse, gross, material, see PED, pp. 170-1.

95 Cittacetasika - I render this here plainly, as 'mental', as one might enter serious tangles trying to be precise about the inter-relation of citta and cetasika here. Thankfully, in this context there is no need.

96 Presumably the yolk.

97 Presumably the shell.

98 Mil., 49.

Rājā āha 'bhante nāgasena, yam panetam brūsi 'nāmarūpan'ti, tattha katamạ̣ nàmam, katamam rüpan'ti.

'Yam tattha, mahārāja, olāarikam, etạn rūpam, ye tattha sukhumā cittacetasikā dhammā, etam nāman'ti.

'Bhante nāgasena, kena kāranena nāmam yeva na pațisandahati, rūpam yeva $v \bar{a} ' t i$ ?

'Añ̃̃amañ̃̄ūpanissitā, mahārāja, ete dhammā ekatova uppajjantī'ti.

'Opammam karohì'ti.

'Yathā, mahārāja, kukkuțyā kalalam na bhaveyya, aṇdampi na bhaveyya, yañca tattha kalalam, yañca andạn, ubhopete añ̃amaññupanissitā, ekatova nesạ̣ uppatti hoti. Evameva kho, mahārāja, yadi tattha nāmam na bhaveyya, rūpampi na bhaveyya, yañceva tattha nämam, yañceva rüpam, ubhopete aññamaññ̄panissitā, ekatova nesam uppatti hoti. Evametam dīghamaddhānam sandhāvitan'ti.

'Kallosi, bhante nāgasenā'ti.

99 Harvey, P., 'The Mind-Body Relationship in Pali Buddhism.' In Asian Philosophy. Vol. 3, No. 1, 1993, p. 39.

100 Ibid., p. 40.

101 We can read M.I.206-07, in the Cūlagosinga Sutta, as an example of 'mind-sharing'. In the Sämmaññaphala Sutta, at D.I.77, we have an example of a 'mind-made body'.

102 If we claim that viññana is distinct from nāma in general, maybe we do not need to worry over this too much; alternatively one might claim that a 'between-lives-state' could have a subtle rūpa aspect to it, and it would certainly include näma.

103 For his full argument on this matter, see Chapter 6 of Harvey, P., The Selfless Mind.

104 Viñ̃āna.

105 Harvey, P., The Selfless Mind. p. 98. It is worth noting that viññana is not to be viewed as the same as the Jain view of the jiva (life-force). It is perhaps in danger here of being seen as something akin to a Self, but the texts seem aware of this danger, and at M.I.256f the Buddha admonishes the bhikkhu Sāti for having claimed that:

As I understand the dhamma taught by the Blessed One, it is this same consciousness that runs and wanders thought the round of rebirths, not another.

(MLD, p. 349)

tathāham bhagavatā dhammam desitạ̣ àjānāmi yathā tadevidạ̣ viññānạ̣ sandhāvati samsarati anaññan.

106 Rebirth 'above' this kāma-loka, but still embodied.

107 M.I.50.

Tayome, āvuso, bhavā-kāmabhavo, rūpabhavo, arūpabhavo.

108 A meditator may attain the 'four formless states', but he or she is still embodied. These are meditation states, achieved using calming Samatha meditation. See Harvey, P., 
An Introduction to Buddhism. p. 251 for an account of these. It is worth noting that their presence in a meditative scheme is not without controversy. Alexander Wynne claims that 'there are a number of suttas that are quite hostile to the idea that the path of formless meditation is orthoprax Buddhism.' Wynne, Alexander, 'An Interpretation of "Released on Both Sides" (Ubhato-bhäga-vimutti), and the Ramifications for the Study of Early Buddhism.' In Buddhist Studies Review. Vol. 19, No. 1, 2002. pp. 31-40, p. 37. Wynne goes on to illuminate a number of controversies with regard to this.

109 An example of this might be found in that an arahat can, it is usually said, experience only physical dukkha, and not the mental (or namma) dukkha that so blights the rest of us.

110 PED, p. 520.

111 Ibid.

112 Harvey, P., 'Coming to Be and Passing Away: Buddhist Reflections on Embryonic Life, Dying and Organ Donation.' In Buddhist Studies Review. Vol. 18, No. 2, 2001. pp. 183-215, p. 185.

113 Such as avijjā, for example.

114 Kalupahana, D. J., Buddhist Philosophy: A Historical Analysis, p. 93.

115 In the Mahāparinibbāna Sutta, at D.II.154.

116 For example at Sn. 21.

117 M.I.135.

Evameva kho, bhikkhave, kullūpamo mayā dhammo desito nittharanatthāya, no gahaṇatthāya.

118 M.I.261.

'Imam ce tumhe, bhikkhave, dițhim evam parisuddham evam pariyodàtạ na allīyetha na kelāyetha na dhanāyetha na mamāyetha, api nu me tumhe, bhikkhave, kullüpamạ̣ dhammam desitam ājāneyyātha nittharanatthāya no gahanatthāyā'ti?

'Evam, bhante'.

119 Bodhi, B., 'The Buddha's Survey of Views.' In Dhammajoti et al. (Ed.), Recent Researches in Buddhist Studies. p. 59.

120 This does not undermine the extent to which the teachings are also 'truth-claims'. Indeed, the teachings would not be functionally efficacious if they were false. That is, if they were based on a misunderstanding of the nature of the world, they would fail as a means to engage and interact with the world in effective ways.

121 Collins, Steven, Selfless Persons. pp. 121-2.

122 A form of upādāna, conditioned by tanhhā.

123 By 'the condition' I of course mean 'the primary' condition rather than sole cause.

124 The PED (p. 149) gives the applied sense of upādāna as " "drawing upon”, grasping, holding on, grip, attachment'. See Chapter 3 for more on the nature of upādāna.

125 D.III.230, and in the analysis of paticca-samuppāda in the Vibhañga sutta at S.II.2.

Cattāri upādānāni - kāmupādānaṃ, dițthupādānạ̣, sīlabbatupādānaṃ, attavādupādānam.

126 Ogha is a flood, the flood of desires and the like by which we are swept away. See PED, pp. 164-5.

127 D.III.230:

Cattāro oghā - kāmogho, bhavogho, dițthogho, avijjogho. 
128 LDB, p. 493.

129 As we have seen, at times, such as at M.I.55, there are only the three, with ditthi not present; elsewhere ditthi makes up a fourth.

$130 v i j j \bar{a}$ - Lack of ignorance. We might consider this as 'insight into the way things really are'. Nānamoli and Bodhi (MLD, p. 163.) translate it as 'true knowledge', but this grates somewhat for someone raised on the definition of knowledge as 'justified true belief' - to call something knowledge is to call it true. Nonetheless I can see their point, as they wish to demonstrate that vijja $\bar{a}$ is the absence of ignorance. Perhaps 'genuine knowledge' would, in the light of this, be preferable.

131 See Chapter 3 for a discussion of paritassana .

132 This is odd in the Pali here. The nibbāna reached is personal - or individually attained and a parinibbāna at the same time. I take this as indicating that it wishes to indicate that it is he, and no one else that attains it.

133 M.I.67:

'Yato ca kho, bhikkhave, bhikkhuno avijjā pahīnāhoti vijjāuppannā, so avijjāvirāgā vijjuppādā neva kāmupādānam upādiyati, na diț̣̂pādānam upādiyati, na sīlabbatupādānam upādiyati, na attavādupādānam upādiyati. Anupādiyạ̣ na paritassati, aparitassam paccattaññeva parinibbāyati. 'khīnā jāti, vusitạ̣ brahmacariyam, katam karaṇìyam, nāparam itthattāyā' ti pajānātī' ti.

134 Abhidhammattha Sangaha. II.4. Comprehensive Manual of Abhidhamma. p. 83.

135 Ibid., p. 84.

136 Anderson, C., Pain and its Ending. p. 33.

137 D.II.80.

138 MLD, pp. 137-8.

Cattārimāni, āvuso, upādānāni- kāmupādānam, dițthupādānam, sīlabbatupādānaṃ, attavādupādānam.

139 PED, p. 321.

140 CSCD Pali-English Dictionary.

141 LDB, p. 234.

142 What is interesting here is that the PTS edition has the four $\bar{a} s a v \bar{a} s$, but the Pali in the CSCD edition reads only:

Paññāparibhāvitam cittam sammadeva āsavehi vimuccati, seyyathidam -

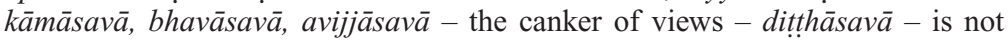
present in this version.

143 Peț. 177.

'Ayamahamasmī ti na samanupassati. Tassa diț̣̂āsavā pahānam gacchanti.

Pit. (p. 241) gives this as "[When] he does not see "I am this", his taints of [wrong] view come to abandonment.' The inclusion of the '[wrong]' here gives a sense which seems to only partly recognise the understanding of views given in this chapter.

144 Gethin, R., 'Wrong View (micchā-dițhi) and Right View (sammā-dițhi) in the Theravāda Abhidhamma.' In Dhammajoti et al. (Ed.), Recent Researches in Buddhist Studies. p. 217-8.

145 Burford, G., Desire, Death and Goodness. pp. 47-8.

146 Translation from SNip. p. 93:

Dhonassa hi natthi kuhiñci loke, pakappitā dițthi bhavābhavesu; māyañca mānañca pahāya dhono, sa kena gaccheyya anūpayo so. 
Upayo hi dhammesu upeti vādam, anūpayam kena katham vadeyya; attā nirattā, na hi tassa atthi, adhosi so ditțimidheva sabbanti.

147 Ibid., p. 95:

Yassūbhayante paṇidhīdha natthi, bhavābhavāya idha vā hurạ̣ vā; nivesanà tassa na santi keci, dhammesu niccheyya samuggahìtam.

148 At least 'doctrine' seems more appropriate to the context here than 'state' or 'thing' which dhamma means in other contexts.

149 Thanissaro, B., The Mind Like Fire Unbound. p. 58. This is rather like the type of desire which has a negative object.

150 Ibid., p. 60. Likewise, craving also brings us into disputes with others, for example where we are both seeking the same finite object of craving.

151 Ibid., p. 61.

152 Ibid., p. 65.

153 Gombrich, R., How Buddhism Began. p. 16. The poems he refers to are the ones in the Sutta-nipāta quoted above.

154 Gethin, R., 'Wrong View (micchā-ditțhi) and Right View (sammā-ditțhi) in the Theravāda Abhidhamma'. p. 218.

155 Collins, S., Selfless Persons. p. 119-20.

156 Thanissaro, B., The Mind Like Fire Unbound. p. 62.

157 Rijken van Olst, B., Right Views or No Views? http://www.theosophynw.org/theosnw/world/asia/rel-bas.htm. [Accessed 5/12/01, Reprinted from Sunrise Magazine, February/March 1990, Theosophical University Press.]

158 Gombrich, R., How Buddhism Began. p. 27.

159 Which means that even if, like the raft, all views are to be ultimately abandoned, some can be more kusala than others - even if, as we shall see, something akin to 'right seeing' is even more kusala.

160 Often - though not in this particular case, it seems - as a lay and a monastic application of the same principle.

161 Translation from MLD, pp. 934-5:

'Katamā ca, bhikkhave, sammāditțhi? sammādiț̣himpaham, bhikkhave, dvāyam, vadāminatthi,

bhikkhave, sammādiț̣hi sāsavā puñ̃abhāgiyā upadhivepakkāéé

atthi, bhikkhave, sammäditthi

ariyā anāsavā lokuttarā maggangāa.'

162 At S.II.16-17 we do get a fuller description of the content of sammäditthi - here being presented in the sense of avoiding the extreme positions of eternalism and annihilationism with regard to the world. However, in this passage there is no distinction between mundane and supramundane sammāditthi.

163 Gethin, R., 'Wrong View (micchā-ditthi) and Right View (sammā-ditthi) in the Theravāda Abhidhamma.' p. 216.

164 Ibid.

165 Most notably ditthis relating Self to the khandhas - which is one of the ten fetters.

166 Gethin, R., 'Wrong View (micchā-ditți) and Right View (sammā-ditthi) in the Theravāda Abhidhamma.' p. 217.

167 Abhidhammattha Sangaha. IX, 30. Comprehensive Manual of Abhidhamma. p. 349.

Lakkhana-rasa-paccupațthāna-padațthāna-vasena nāma-rüpapariggaho dit thivisuddhi nāma. 
'Kiṃ nu kho, àvuso, diț̣hivisuddhattham bhagavati brahmacariyam vussat̄̄'ti? 'No hidam, àvuso'.

169 Patis. I.21-2.

170 Translation from TPD, p. 24.

171 Vism. XIV, 32.

172 See Collins, S., Selfless Persons. p. 112.

173 Which are an expanded form of the purifications - of virtue, view, overcoming of doubt, knowledge and vision of what is and is not the path, final nibbanna given in the 'relay of chariots' in the Rathavinita Sutta, at M.I.149-50. Here note how 'knowledge and vision' are seen as more advanced than purification of view.

174 PoP, p. 442:

Sìlavisuddhi ceva cittavisuddhi cāti imā dve visuddhiyo mūlạ̣.

175 Ñānananda, B., Concept and Reality in Early Buddhist Thought. p. 40.

176 Anderson, C., Pain and its Ending. p. 37. This threefold classification of views is taken from Steven Collins' Selfless Persons. p. 88f.

177 And with reference to Anderson's position, can be 'not held' - indeed such a direct seeing is so much a feature of a flexible and insightful mind, that it might be said to be not possible for it to hold a view, rather than to just 'see'.

178 Translation from MLD, p. 592; M.I. 486:

'Atthi pana bhoto gotamassa kiñci dițthigatan'ti?

'Dițthigatanti kho, vaccha, apanītametam tathāgatassa. Dițțāñnhetam, vaccha, tathāgatena- "iti rūpam, iti rūpassa samudayo...".

179 MLD, p. 1273 , n. 720.

180 PED, p. 320.

181 Although they may, as Gethin suggested earlier, already have been left behind prior to Enlightenment, at 'stream-entry'.

182 Kalupahana, David, 'The Philosophy of History in Early Buddhism.' In JPTS, Vol. IX, 1981, p. 119.

183 We saw previously, in Sn.786, that a 'mentally constructed view' was identified as something absent from one who has attained a lofty spiritual goal.

184 Frank, J., Rationality and Mind in Early Buddhism. p. 96.

185 S. III. $257-8$.

186 Translation from CDB, p. 1031; S.III. 257; ditțigatāni loke uppajjanti.

$187 \mathrm{CDB}$, pp. 1031-33. These represent a sequence of section headings summarising the contents of this section.

188 Burford, G., Death, Desire and Goodness. pp. 58-9.

189 The composers of the Atthakavagga, presumably.

190 It is not clear why something's being less obvious should be taken as inferring that it is inherently more troublesome.

191 Burford, G., Death, Desire and Goodness. pp. 59-60.

192 Translation from CDB, p. 549:

avijjānīvaraṇassa, bhikkhave, bālassa taṇhāya sampayuttassa evamayam kāyo samudāgato. 
193 Ko cāhāro avijjāya? 'Pañca nīvarañā' (A.V.113) - 'What is the nourishment of ignorance? The Five Hindrances.' The Five Hindrances are kāmacchanda (sensual-desire) usually, as we saw above; vyāpāda (ill-will); thina-middha (sloth and torpor); uddhacca-kukacca (restlessness and worry) and vicikicchā (doubt).

194 Ko cāhāro bhavatanhhāya? 'Avijjā' (A.V.117). - 'What is the nourishment of cravingfor-existence? Ignorance.'

195 The sutta is explaining that while we can identify the conditions for ignorance, its nourishment, this must be understood in the context of there being no first point of ignorance. A.V.113:

Purimā, bhikkhave, koṭi na paññāyatiavijjāya- 'ito pubbe avijjā nāhosi, atha pacchà samabhavì'ti.

Translation from NDB, p. 254: 'A first beginning of ignorance, $\mathrm{O}$ monks, cannot be discerned, of which it can be said, "Before that, there was no ignorance and it came to be after that.",

We find that same said at A.V.116 of bhava-tanhā.

196 Translation from Ud-It., p. 160. Avijjānīvaraṇasuttam, It. Sutta 14:

Nāhaṃ, bhikkhave, añ̃am ekanīvaraṇampi samanupassāmi yena, nīvaraṇena nivutā pajā dīgharattam sandhāvanti samsaranti yathayidam, bhikkhave, avijjānīvaraṇam.

197 Translation from Ud-It., p. 161. Taṇhāsamyojanasuttam, It. Sutta 15:

Nāham, bhikkhave, añ̃am ekasaṃojanampi samanupassāmi yena, samyojanena samyuttā sattā dīgharattam sandhāvanti samsaranti yathayidam, bhikkhave, tanhāsamyojanam.

198 Gethin, R., 'Wrong View (micchā-ditți) and Right View (sammā-ditthi) in the Theravāda Abhidhamma'. p. 221.

199 Ibid., p. 224.

200 As the unique telos of humanity, see book VI of The Nicomachean Ethics.

201 PED, p. 292. Fumimaro Watanabe separates out two of the ideas at work in takka. He distinguishes the sense of reasoning (be it true or false), from the sense of 'sophistry' and 'hair splitting'. This seems accurate enough, albeit being a distinction in danger of becoming an act of hair-splitting itself. See Watanabe, F., Philosophy and its Development in the Nikāyas and Abhidhamma. p. 94.

202 The CSCD gives this sutta the name kesamutti-sutta. One could maybe read this as meaning the sutta on 'what liberates?'. However, on closer reading it seems that Kesamutta is the name of the town - given in the NDB translation (p. 64), and in the PTS printed edition as Kesaputta (although the PTS edition notes that the Chattha Sangitti Pitakam [the manuscript basis of the CSCD] has kesamutta here - Morris, Rev. Richard (Ed.), Anguttara Nikāya. Vol. I. p. 189).

203 A.I.189.

204 We could perhaps, in a Buddhist view, here equate efficacy with accuracy making the Buddha seem like one who subscribed to a pragmatic theory of the nature of truth. However, while in this context such an approach may fit, there is more to the Buddhist approach to truth than a crude pragmatism - indeed we find elements of all three key Western theories of truth (correspondence, coherence and pragmatic) within the Buddhist view of the nature of truth and its relation to propositions. 
mā anussavena, mā paramparāya, mā itikirāya, mā pițakasampadānena, mā takkahetu, mā nayahetu, mā ākāraparivitakkena, mā diț̣inijjhānakkhantiyā, mā bhabbarūpatāya, ma samaṇo no garūti.

206 If not quite logical positivist. Frank Hoffman argues strongly against seeing Buddhism as a form of empiricism. See Hoffman, F. J., Rationality and Mind in Early Buddhism. p. 96. He however seems to limit his sense of 'empiricism' to one rather like that of logical positivism.

207 Kalupahana, D., Buddhist Philosophy: A Historical Analysis. p. 16.

208 Sn. 209. takkam pahāya. Trans. from SNip. p. 22.

$209 \mathrm{~K}$. Jayatilleke argues that in order to understand takka we need to understand who the term applied to - who was it that, in the Kälamma-sutta, the Buddha's comments are directed towards. For a detailed discussion of the takki, the users of takka, see Jayatilleke, K. N., Early Buddhist Theory of Knowledge. p. 206f.

210 And while some forms of Buddhism are well-known for trying to subvert (and at times it seems, unhinge) the rational mind (such as in the Zen use of the kōan), elsewhere in later thought we also find reason elevated, such as in the use of logic within Tibetan Buddhism.

211 At times, it almost seems to go over the top in this respect, as any reader of the more tangled portions of the Abhidhamma will testify.

212 PED, p. 644.

213 We can also see vicāra as close to this in meaning.

214 For a detailed treatment of many of these issues, see Jayatilleke, K. N., Early Buddhist Theory of Knowledge.

215 See PED, p. 733.

216 PED, p. 667.

217 A minor term which is a little closer to 'reason' in the sense I am discussing here is ühana. Given by the PED as 'reasoning, consideration, examination' (PED, p. 159), this term is fairly rare in the Canon. If we look to the newer ADP definition, we can see that $\bar{u}$ hana is still some way from 'reason' in the logical sense: 'paying attention (to), considering; reasoning, deliberation' (ADP, p. 524). This then, is rather like some of the above terms.

218 The factors of awakening - the bojjhangas - are discussed in detail in Chapter 5 of Gethin's The Buddhist Path to Awakening.

219 LDB, p. 420. The PED (p. 615) gives vicaya as 'search, investigation, examination', and Walshe is here taking dhamma in the sense of aspects of our mental profile.

220 Gethin, Rupert, The Buddhist Path to Awakening. p. 152. He also, in footnote 38 of the same page, registers some disquiet with the translation of vicaya as 'investigation'.

221 Sammä-ditthi can be seen as the possession of knowledge, in that it represents the holding of accurate views (as in ordinary sammā-ditthi), but this also can be transcended (in noble sammā-ditthi) by the direct seeing discussed above. By 'knowledge' here, I am referring to the direct seeing, or insight into the accuracy of sammā-dițhi.

222 D.II.217. Sammāñānassa sammāvimutti pahoti. 'From right-knowledge arises rightliberation.' This is the end of a sequence where each of the path-factors is seen as arising on the basis of the former.

223 See Warder, A. K., Introduction to Pali. p. 97, for an explanation of this type of compound.

224 M.I.195. MLD, p. 289. Here the usage is explained, MLD, p. 1223, n. 347, as relating to the 'divine eye' - the ability to see things that normal vision cannot. The term is used elsewhere without this sense though. 
225 Where 'the prior element is associated with the posterior by a direct relation', Warder, A. K., Introduction to Pali. p. 78.

226 Furthermore, avijja is not to be seen as purely negative - just as the absence of knowledge - but rather can be seen in terms of the misperception and ignor-ance noted earlier in this chapter. As Etienne Lamotte writes: 'Avidyā, which appears at the top of the Conditioned Co-Production and which I have rendered 'ignorance', is less an absence of knowledge than a false knowledge.' Lamotte, Etienne, 'Conditioned Coproduction and Supreme Enlightenment.' In Balasooriya, S., et al. (Eds.), Buddhist Studies in Honour of Walpola Rahula. p. 119.

227 Ditthi, in negative forms, can be seen as a combination of the two - the grasping relates to desire, the avijja representing the partiality of asserting one set of views over another in a way based on misperception.

228 There may also be an element of 'ignor-ance' here: having a vague sense of unease about our desires, but surpressing or ignoring it.

229 Translation from Ud-It. p. 184. Dițthigatasuttam, It. Sutta 49:

Dvīhi, bhikkhave, dițthigatehi pariyuțthitā devamanussā olīyanti eke, atidhāvanti eke; cakkhumanto ca passanti.

230 Vacillation and clinging to precept and vows.

231 For an account of this process, see Harvey, P., An Introduction to Buddhism. p. 71.

\section{CONCLUSION: DESIRE AND THE TRANSFORMATION OF LIVING}

1 Nanda sutta, Ud. 3.2:

Yassa nittinno panko, maddito kämakanțako; mohakkhayam anuppatto, sukhadukkhesu na vedhatī sa bhikkhū.

2 Warhol, Andy, attributed. In Bloomsbury Thematic Dictionary of Quotations. p. 98.

3 These two could well be seen as represented in Buddhist thought by avijjā and tanha $\overline{\text {. }}$

4 Butler, J., Subjects of Desire. p. 193.

5 Maybe this assertion is a little rash. I am of the firm opinion that this is the case, but how do I justify this belief as true? This is perhaps not the place for this discussion. Maybe my lack of an elephantine facial member is what certain philosophers call a 'properly basic belief'.

6 Like an elephant's trunk perhaps?

7 Although this would clearly not apply to aversion.

8 Butler, J., Subjects of Desire. p. 238.

9 Ibid.

10 Ibid.

11 Atharva-Veda, X.24-5. Bloomfied, M. (trans.), Hymns of the Atharva-Veda. p. 223.

$12 \mathrm{Be}$ it through the intention of Vedic ritual, or the reproductive act, or the intent which drives karma and hence samsāra.

13 Translation from Ud-It., p. 48. Sippa sutta, Ud. 3.9:

Asippajīvī lahu atthakāmo,

yatindriyo sabbadhi vippamutto;

anokasārā amamo nirāso,

hitvā mānam ekacaro sa bhikkhū 
14 Without as $\bar{a}$ - hope (as seen in Chapter 3).

15 Were we to take a Sarvāstivādin view, a third option would be available: that negative cetasikas would still be present in an Arahat, as all dhammas persist in all three times (past, present and future), but they would be 'deactivated'. They would not just be inactive, but aprāpti - permanently turned off.

16 If we take an Abhidhamma view, no phenomenon can continue to be present over time - at least if we take seriously the notion of 'momentariness' - whereby mental states are constantly passing away and arising. The effect, however, within our consciousness appears as seamless. See Harvey, P., An Introduction to Buddhism. p. 84.

17 Although a less altered form of kusala chanda can exist in the non-enlightened.

18 Dylan, B. 'Chimes of Freedom,' In B. Dylan, Writings and Drawings. p. 198.

19 See Chapter Two of Sartre's Being and Nothingness.

20 Kant, Immanuel, Grounding for the Metaphysics of Morals. Section 2, p. 28.

21 Guttari, F., Molecular Revolution: Psychiatry and Politics. Cited in: Fuery, P., Theories of Desire. p. 98.

22 Nietzsche, Beyond Good and Evil, I.1, p. 1.

23 Ibid., I.4, p. 3.

24 One might speculate that some later forms of Buddhism suggest other criteria than truth in their assessment of the value of beliefs. If we take seriously the idea of 'skilful means' - a belief may be valuable to an individual, in that it propels them toward Buddhahood, but not true in any absolute sense - particularly in the context of the emptiness (śūnyatā) of all dharmas.

25 In the sense Rudolph Otto uses the idea in his Idea of the Holy - although the experience of nibbāna may be rather akin to his concept of the numinous.

26 Of course, Zen Buddhism is renowned for its concern with seeking to move us beyond the limits of the rational, most obviously via the use of kōans.

27 Were reason capable of delivering us from our woes, we would surely see the spectacle of depressed patients emerging from their therapists with logic textbooks in their hands. To an extent, though, some have wished to extend the role of 'reason' in therapeutic contexts - such as the recent developments in 'philosophical counselling' and aspects of cognitive behavioural therapy. None but perhaps the most enthusiastic proponents of these approaches would be likely to suggest that reason is the solution to all our mental ills. In seeking, especially in philosophical counselling, to encourage clear thinking in the troubled, the approach seems partly in concurrence with the Buddhist methods I have been outlining here (except that, for the Buddhist, we all need this therapy).

28 Shakespeare, Troilus and Cressida. 3.1.80.

29 The sense that we are seeking to obtain that which we have not.

30 And possibly some dhamma-directed desire. An akusala-tanhā desire for spiritual progress, a grasping after enlightenment is not helpful, and by definition - by being akusala - it will not contribute to forward movement on the path.

31 Along with our misperception of this, and possibly our refusal to recognise this - our ignor-ance.

32 I am also, in this context, somewhat taken by the French writer Paul Valéry's line: 'God made everything out of nothing. But the nothingness shows through.' Bloomsbury Dictionary of Thematic Quotations. p. 79.

33 Barrett, W., Irrational Man: A Study in Existential Philosophy. p. 220.

34 Ibid.

35 Ibid.

36 Have it either way you like - I am not going to even begin, this late in the project, to get drawn into the orbit of such a tangled mess as the definition and limits of the spiritual vis-à-vis the psychological: such metaphysical wrangling could surely only do me harm, cf. Chapter 4 on ditthi. 
37 Medhidhammaporn, P., Sartre's Existentialism and Early Buddhism. p. 80.

38 Hedges, W., Lacan: Some Key Concepts. http://www.sou.edu/English/Hedges/ Sodashop/RCenter/Theory/People/lacankey.htm [Accessed 10/02/02].

39 Other than perhaps in the sense of those seeking scientific or scholarly objectivity, but even this notion now lies besieged, with the postmodernists at the gate.

40 Proverbs, 11.23. RSV Bible, p. 568.

41 Kant, I., Grounding for the Metaphysics of Morals. p. 7.

42 See Chapter 3, tanh $\bar{a}$ section

43 Translation from NDB, pp. 90-1. A.II.49. Also found at S.I.62:

Gamanena na pattabbo, lokassanto kudācanam; na ca appatvā lokantam, dukkhā atthi pamocanam.

Tasmā have lokavidū sumedho, lokantagū vusitabrahmacariyo; lokassa antạ̣ samitāvi ñatvā, nāsīsatī, lokamimam parañcāa.

44 In the words of the Portuguese poet Pedro Tamen:

Wanting not, seeing not, knowing not.

Dying is indeed the difficult thing.

Tamen, P., 'Go down slowly till you reach limbo.' In P., Tamen, Honey and Poison: Selected Poems. p. 33.

45 Otherwise the religious quest of Buddhism would become equivalent with an attempt to fulfil a vibhava-tanh $\bar{a}$ - a craving for non-being. The question on the status of a tathaggata after death is one that the Buddha, at S.IV.375, will not declare an answer to. There is no consensus on the reasons for this, but I am in no position to enter into a debate about this here.

46 Sophocles, Antigone, 887-894. In R. Fagles, (trans.), Sophocles: The Three Theban Plays. p. 101.

47 From a talk given by Harlan B. Miller to the Unitarian Universalist Fellowship of New River Valley, http://www.montgomery-floyd.lib.va.us/compages/uufnrv/hmiller.html [Accessed 30/4/02].

48 Saint Theresa of Avila, 'Untitled.' In Cosman, Keefe and Weaver (Eds), The Penguin Book of Women Poets. p. 120.

49 Capobianco, R., 'Lacan and Heidegger: The Ethics of Desire and the Ethics of Authenticity.' In B. Babich, (Ed.), From Phenomenology to Thought, Errancy, and Desire. p. 393.

50 The 'seven factors of awakening', the bojjhangas, contain pitti-joy, and Gethin says of it (along with passaddhi - tranquillity): 'Together pìti and passaddhi are terms suggestive of the positive emotional content of ancient Buddhism.' Gethin, Rupert, The Buddhist Path to Awakening. p. 156. We also can point to the energy of viriya as one of the bojjhangas - again enlivening our notion of the Buddhist path.

51 Blake, W., Eternity. In P. H. Butter (Ed.), William Blake: Selected Poems. p. 45.

52 Who died in 438 BCE.

53 Pindar, 'Pythian III.' In The Odes of Pindar.

54 Akhmatova, A., 'Untitled Poem, 1964.' In D. M. Thomas (trans.), Anna Akhmatova: Selected Poems. p. 85.

55 Nietzsche, Thus Spoke Zarathustra. p. 162.

56 The third chapter of $A$ Sketch of a Phenomenological Theory addresses this particularly.

57 Stevenson, L., Seven Theories of Human Nature. p. 83. 
58 And what other world can there be? In a context of post-Kantian epistemology, it would seem that the only world we have is the one we live in. While Buddhism may offer us ways of living in a world-of-experience less unpleasant and more fulfilling, this is as much by changing our internal landscapes as attaining a God's-eye view of radical objectivity.

59 Chāndogya Upanișad. 7.4.2. P. Olivelle (trans.), Upanișads. p. 158. Here intention is the translation of samkalpa.

60 Padmasiri De Dilva, M. W., Buddhist and Freudian Psychology. p. 108.

61 Nietzsche, F., Twilight of the Idols. p. 43.

62 Ibid., p. 43. 


\section{BIBLIOGRAPHY}

Sources listed in the abbreviations at the start of the book are not included in this bibliography.

Akhmatova, A., Selected Poems. Penguin, London, 1988.

Alt, W., 'There is no paradox of desire in Buddhism.' In Philosophy East \& West. Vol. 30.4, 1980. pp. 521-30. http://pears2.lib.ohio-state.edu/FULLTEXT/JR-PHIL/wayne.htm [accessed 01/05/2002].

American Philosophical Association 'American Philosophical Association Guidelines for Non-Sexist Use of Language.' In Proceedings and Addresses of the American Philosophical Association. Vol. 59, No. 3, 1986.

Anderson, C., Pain and its Ending: The Four Noble Truths in the Theravāda Buddhist Canon. Curzon Press, Richmond, 1999.

Anderson, P. S., A Feminist Philosophy of Religion. Blackwell Publishers, Oxford, 1998.

Aristotle, The Nicomachean Ethics (World Classics Edition), Oxford University Press, Oxford, 1980.

Armstrong, J., Conditions of Love: The Philosophy of Intimacy. Penguin, London, 2002.

St Augustine, Confessions. Penguin, London, 1961.

Ayer, A. J., Language, Truth and Logic. Penguin, London, 1971.

Ayer, A. J., The Foundations of Empirical Knowledge. Penguin, London, 1969.

Ayer, A. J., The Problem of Knowledge. Penguin, London, 1956.

Barrett, W., Irrational Man: A Study in Existential Philosophy. Heinemann, London, 1967.

Bartholomew, C., Reading Ecclesiastes: Old Testament Exegesis and Hermeneutical Theory. Editrice Pontifico Istituto Bilbico, Rome, 1998.

Batchelor, S., Alone With Others: An Existential Approach to Buddhism. Grove Press, New York, 1983.

Bhartrihari and Bilhana, The Hermit and the Love Thief (Trans.) Stoler-Miller, Barbara, Penguin, London, 1990.

Biardeau, M., Hinduism: The Anthropology of a Civilization. Oxford University Press, Delhi, 1989.

Bible, RSV Edition. Collins, London, 1952.

Bihārī, The Satasaī. Penguin, London, 1990.

Blake, W., Selected Poems. J M Dent \& Sons, London, 1991.

Blavatsky, H., Collected Writings, compiled by Boris de Zirkoff, found at the Esoteric Studies Guide web-site. http://www.geocities.com/katinka_hesselink/will.htm [accessed 7/7/01]. 
Bloomfied, M. (Trans.), Hymns of the Atharva-Veda. Motilal Banarsidass, Delhi, 1964.

Bloomsbury Thematic Dictionary of Quotations. Bloomsbury Publishing Ltd, London, 1990.

Bodhi, B. et al. (Eds. and Trans.), A Comprehensive Manual of Abhidhamma: The Abhidhammattha Sangaha of Ācariya Anuruddha. Buddhist Publication Society, Kandy, 1993.

Bodhi, B., 'The Buddha's Survey of Views.' In Dhammajoti et al. (Ed.), Recent Researches in Buddhist Studies. Y. Karunadasa Felicitation Committee, Colombo \& Chi Ying Foundation, Hong Kong, 1997.

Bodhi, B. (Trans.), The Discourse on The All-Embracing Net of Views: The Brahmajāla Sutta and its Commentaries. Buddhist Publication Society, Kandy, 1992.

Boisvert, M., The Five Aggregates: Understanding Theravāda Psychology and Soteriology. Canadian Corporation for Studies in Religion, Vol. 17, Wilfred Laurier University Press, Canada, 1995.

Boundas, C. V. (Ed.), The Deleuze Reader. Columbia University Press, New York, 1993.

Bowker, J. (Ed.), The Oxford Dictionary of World Religions. Oxford University Press, Oxford, 1999.

Brockington, J, 'The Bhagavadgītā: Text and Context.' In J. Lipner (Ed.), The Fruits of our Desiring: An Enquiry into the Ethics of the Bhagavadgītā. Bayeux Arts, Canada, 1997.

Bryson, B., The Penguin Dictionary of Troublesome Words. Penguin, London, 1987.

Burford, G., Desire, Death, and Goodness; The Conflict of Ultimate Values in Theravāda Buddhism. Peter Lang, New York, 1991.

Butler, J., Subjects of Desire: Hegelian Reflections in Twentieth Century France. Columbia University Press, New York, 1999.

Capobianco, R., 'Lacan and Heidegger: The Ethics of Desire and the Ethics of Authenticity.' In B. Babich (Ed.), From Phenomenology to Thought, Errancy, and Desire. Kluwer Academic Publishers, Holland, 1995, pp. 391-6.

Chapple, C., Karma and Creativity. State University of New York Press, New York, 1986.

Churchland, P., Matter and Consciousness. Massachusetts Institute of Technology, Massachusetts, 1988.

Collins English Dictionary, Electronic Edition Version 1.5, 1992.

Collins, S., Selfless Persons: Imagery and Thought in Theravāda Buddhism. Cambridge University Press, Cambridge, 1982.

Cosman, Keefe, Weaver (Eds), The Penguin Book of Women Poets. Penguin, London, 1978.

Coulson, N. J., A History of Islamic Law. Edinburgh University Press, Edinburgh, 1978.

Cousins, L., 'Good or Skilful? Kusala in Canon and Commentary.' In Journal of Buddhist Ethics, Vol. 3, 1996, pp. 136-64. Available at http://jbe.gold.ac.uk/3/cousins1.html [accessed 28/05/02].

Cousins, L., 'The Patthāna and the Development of the Theravādin Abhidhamma.' In JPTS, Vol. IX, 1981.

Coward, H., Derrida and Indian Philosophy. State University of New York Press, 1990.

Dasgupta, S., A History of Indian Philosophy, Vol. 1. Cambridge University Press, Cambridge, 1922.

Davids, R., 'On the Will in Buddhism.' In The Journal of the Royal Asiatic Society of Great Britain and Ireland, 1898:1.

Deleuze, G., Nietzsche \& Philosophy. Athlone Press, London, 1983.

De Silva, C. L. A., A Treatise on Buddhist Philosophy or Abhidhamma. Sri Satguru Publications, Delhi, 1988. 
Dipa, S. B. P. Salient Articles on Buddha Dasena. On-line at http://nibbana.topcities.com/ panadpa9.htm [accessed 18/3/02].

Dollimore, J., Death, Desire \& Loss in Western Culture. Penguin, London, 1998.

Dostoyevsky, F., Notes from the Underground. Dover Publications, New York, 1992.

Dylan, B., Writings and Drawings. Granada Publishing Ltd, London, 1974.

Eliot, T. S., Selected Poems. Faber and Faber, London, 1954.

Faure, B., The Red Thread: Buddhist Approaches to Sexuality. Princeton University Press, Princeton, 1998.

Fuery, P., Theories of Desire. Melbourne University Press, Melbourne, 1995.

Flood, G., An Introduction to Hinduism. Cambridge University Press, Cambridge, 1996.

Gambhirananda (Swami) (Trans.), Eight Upanișads, Volume One: With the Commentary of Śàikarācārya. Advaita Ashrama, Calcutta, 1989.

Ganapti, S. V. (Trans.), Sāma Veda. Motilal Banarsidass Publishers, Delhi, 1992.

Gardner, H. (Ed.), The Metaphysical Poets, 2nd edition, Oxford University Press, Oxford, 1967.

Geiger, W., Pāli Literature and Language. Munshiram Manoharlal Publishers, Calcutta, 1996.

Gethin, R., The Buddhist Path to Awakening. Oneworld Publications, Oxford, 2001.

Gethin, R., 'Wrong View (micchā-dițhi) and Right View (sammā-dițhi) in the Theravāda Abhidhamma.' In Dhammajoti et al. (Ed.), Recent Researches in Buddhist Studies. Y. Karunadasa Felicitation Committee, Colombo \& Chi Ying Foundation, Hong Kong, 1997.

Goethe, Selected Verses. Penguin, London, 1964.

Gombrich, R. F., How Buddhism Began: The Conditioned Genesis of the Early Teachings. Athlone Press, London, 1996.

Goodheart, E., Desire and its Discontents. Columbia University Press, Columbia, 1994.

Gorkom, N. van, Cetasikas. Zolag Press, London, 1999.

Govinda, L. A., The Psychological Attitude of Early Buddhist Philosophy. Rider and Company, London, 1969.

Hardy, F., Viraha-bhakti: The Early History of Krșna Devotionalism in South India. Oxford University Press, Delhi, 1983.

Harvey, P., An Introduction to Buddhism. Cambridge University Press, Cambridge, 1990.

Harvey, P., 'Coming to Be and Passing Away: Buddhist Reflections on Embryonic Life, Dying and Organ Donation.' In Buddhist Studies Review, Vol. 18, No. 2, 2001, pp. 183-215.

Harvey, P., 'Criteria for Judging the Unwholesomeness of Actions in the Texts of Theravāda Buddhism.' In Journal of Buddhist Ethics, Vol. 2, 1995, pp. 140-51.

Harvey, P., “ "Signless" Meditation in Pāli Buddhism.' In The Journal of the International Association of Buddhist Studies, Vol. 9, No. 1, 1986, pp. 25-52.

Harvey, P., 'The Between-lives State in the Pāli Suttas.' In P. Connolly (Ed.), Perspectives on Indian Religions - Papers in Honour of Karol Werner. Sri Satguru Publications, Delhi, 1986.

Harvey, P., 'The Mind and its Development in Theravāda Buddhism.' In Communication \& Cognition, Vol. 33, No. 1/2, 2000, pp. 65-82.

Harvey, P., 'The Mind-Body Relationship in Pali Buddhism: A Philosophical Investigation.' In Asian Philosophy, Vol. 3, No. 1, 1993, pp. 29-41.

Harvey, P., The Selfless Mind: Personality, Consciousness and Nirvana in Early Buddhism. Curzon Press, London, 1995.

Harvey, P., 'The Transmission of Truth in the Buddha's First Sermon.' In Buddhist Studies Review, Vol. 7, No. 1/2, 1990, pp. 19-24. 
Hedges, W., Lacan: Some Key Concepts. http://www.sou.edu/English/Hedges/Sodashop/ RCenter/Theory/People/lacankey.htm [accessed 10/02/02].

Hegel, G. W. F., Phenomenology of Spirit [Trans. A. V. Miller], Oxford University Press, Oxford, 1977.

Herman, A. L., 'Ah, But There is a Paradox of Desire in Buddhism - A Reply to Wayne Alt.' In Philosophy East \& West, Vol. 30.4, 1980, pp. 529-32. http://pears2.lib. ohio-state.edu/FULLTEXT/JR-PHIL/herman2.htm [accessed 01/05/2002].

Herman, A. L., 'A Solution to the Paradox of Desire in Buddhism.' In Philosophy East \& West, Vol. 29.1, 1979, pp. 91-4. http://sino-sv3.sino.uni-heidelberg.de/FULLTEXT/ JR-PHIL/ew26801.htm [accessed 01/05/2002].

Hobbes, T., Leviathan. Penguin, London, 1968.

Hoffman, F. J., Rationality and Mind in Early Buddhism. Motilal Banarsidass, Delhi, 1987.

Horner, I. B. (Trans.), Middle Length Sayings, Vol. 1, Pali Text Society, Oxford, 1995.

Howells, C., 'Sartre: Desiring the Impossible.' In Continental Philosophy: Philosophy \& Desire, Vol. VII, Routledge, 2000.

Hume, D., A Treatise of Human Nature. Penguin Classics, London, 1985.

Iyengar, B. K. S., Light on Yoga. Allen \& Unwin, London, 1968.

Jacobi, H. (Trans.), Jaina Sutras: Part I: The Ākārāniga Sūtra \& The Kalpa Sūtra. Motilal Banarsidass, Delhi, 1964.

Jayasuriya, W. F., The Psychology and Philosophy of Buddhism. Buddhist Missionary Society, Kuala Lumpur, 1976.

Jayatilleke, K. N., Buddhism and Peace. Buddhist Publication Society, Kandy, 1969.

Jayatilleke, K. N., Early Buddhist Theory of Knowledge. Allen \& Unwin, London, 1963.

Johansson, R. E. A., 'Citta, Mano, Vinnana - A Psychosemantic Investigation.' In University of Ceylon Review, Vol. 23, 1965, pp. 165-215.

Johansson, R. E. A., The Dynamic Psychology of Early Buddhism. Curzon Press, Oxford, 1979.

Kalupahana, D., Buddhist Philosophy: A Historical Analysis. University Press of Hawaii, Hawaii, 1976.

Kalupahana, D., 'The Philosophy of History in Early Buddhism.' In JPTS, Vol. IX, 1981, pp. 117-26.

Kant, I., Grounding for the Metaphysics of Morals. Hackett, Indianapolis, 1993.

Keown, D., The Nature of Buddhist Ethics. Macmillan Press Ltd, London, 1992.

Killingley, D., 'Enjoying the World: Desire (kāma) \& the Bhagavadgītā.' In J. Lipner (Ed.), The Fruits of our Desiring: An Enquiry into the Ethics of the Bhagavadgitta. Bayeux Arts, Canada, 1997. (This is a revised version of the paper below.)

Killingley, D., Enjoying the World: Desire (kāma) and the Bhagavad-Gìtā. Unpublished conference paper (presented at the 1995 conference of the Dharam Hinduja Institute of Indic Studies, Cambridge).

Killingley, D., Käma. (Unpublished paper, now included in The Hindu World, (Ed.), Sushil Mittal, Routledge, 2004.)

Killingley, D. (Trans.), Readings from the Hindu Tradition. University of Newcastle, Department of Religious Studies, 1993 (Unpublished).

Lamotte, E., 'Conditioned Co-production and Supreme Enlightenment.' In S. Balasooriya et al. (Eds.), Buddhist Studies in Honour of Walpola Rahula. Gordon Fraser, London, 1980.

Landau, J., Desiring-Machines. http://cs.art.rmit.edu.au/deleuzeguttarionary/d/pages/ desiring-machines.html [accessed 01/05/2002]. 


\section{BIBLIOGRAPHY}

Lash, N., 'The Purification of Desire.' In J. Lipner (Ed.), The Fruits of our Desiring: An Enquiry into the Ethics of the Bhagavadgītā. Bayeux Arts, Canada, 1997.

Leavy, P., 'Grande, Decaf, Low Fat, Extra Dry Cappuccino: Postmodern Desire.' In A Journal of Media and Culture, Vol. 2, No. 5, 1999. http://www.uq.edu.au/mc/9907/ grande.html [accessed 14/01/2002].

Lechte, J., Fifty Key Contemporary Thinkers. Routledge, London, 1994.

Lee, J. H., 'Sovereign "Subjectivity" in Bataille.' In The Journal of the British Society for Phenomenology, Vol. 32, No. 1, 2001.

Levertov, D., 'A Common Ground.' In Penguin Modern Poets 9. Penguin, London, 1967.

Levi, P., Collected Poems. Faber and Faber, London, 1988.

Ling, T., A History of Religion East and West. Macmillan Publishers Ltd, London, 1968.

Lipner, J., Hindus: Their Religious Beliefs and Practices. Routledge, London, 1994.

Lipner, J., 'Prolegomena.' In J. Lipner (Ed.), The Fruits of our Desiring: An Enquiry into the Ethics of the Bhagavadgītā. Bayeux Arts, Canada, 1997.

Locke, J., An Essay Concerning Human Understanding. Collins Sons and Co. Ltd, London, 1964.

MacIntyre, A., A Short History of Ethics. Routledge, London, 1967.

Marr, R., Gandhi, the 'Gita', and Violence in This Strange World. http://www.drury.edu/ multinl/story/cfm?ID $=4375 \& N L I D=166$ [accessed 28/05/02].

Matthews, B., Craving and Salvation: A Study in Buddhist Soteriology. Canadian Corporation for Studies in Religion, Vol. 13, Wilfrid Laurier University Press, Ontario, 1983.

Massumi, B., A User's Guide to Capitalism and Schizophrenia: Deviations from Deleuze and Guattari. Massachusetts Institute of Technology (MIT), Massachusetts, 1992.

Medhidhammaporn, P., Sartre's Existentialism and Early Buddhism. Buddhadhamma Foundation, Bangkok, 1988.

Mizuno, K., Buddhist Sutras: Origin, Development, Transmission. Kosei Publishing Co., Tokyo, 1982.

Modern Humanities Research Association (MHRA), MHRA Style Book: Notes for Authors, Editors and Writers of Theses. MHRA, London, 1996.

Moore, G. E., Principia Ethica. Prometheus Books, New York, 1988.

Morris, Rev., R. (Ed.), Anguttara Nikāya, Vol. I, Pali Text Society, Oxford, 1961.

Morrison, R. G., Nietzsche and Buddhism: A Study in Ironic Affinities. Oxford University Press, Oxford, 1997.

Morrison, R. G., 'Two Cheers for Taṇhā.' In Contemporary Buddhism, Vol. 2, No. 1, 2001, pp. $99-119$.

Nabokov, V., Lectures on Russian Literature. Pan Books, London, 1983.

Ñānajīvako, B., Schopenhauer and Buddhism. Buddhist Publication Society, Kandy, 1988 [Wheel Publication 144/146].

Nānanananda, B., Concept and Reality in Early Buddhist Thought. Buddhist Publication Society, Kandy, 1976.

Nietzsche, F., Twilight of the Idols/The Anti-Christ. Penguin, London, 1968.

Nietzsche, F., Thus Spoke Zarathustra. Penguin, London, 1969.

Nietzsche, F., Beyond Good and Evil. Dover Publications, New York, 1997.

Nietzsche, F., The Genealogy of Morals. Oxford Paperbacks, Oxford, 1998.

Norman (Trans.), The Group of Discourses: The Sutta Nipāta, Vol. II. Pali Text Society, London, 1992.

O’Flaherty, W., Śiva: The Erotic Ascetic. Oxford University Press, Oxford, 1981. 
O'Flaherty, W. (Trans.), The Rig Veda: An Anthology. Penguin, London, 1981.

Olivelle, P. (Trans.), Upanișads. Oxford University Press, Oxford, 1996.

Olkowski, D. E., 'Deleuze and Guttari: Flows of Desire and the Body.' In Continental Philosophy: Philosophy \& Desire, Vol. VII, Routledge, 2000.

Otto, R., The Idea of the Holy. Oxford University Press, Oxford, 1958.

Padmasiri De Dilva, M. W., Buddhist and Freudian Psychology. Lake House Investments Ltd, Colombo, 1973.

Perera, L. P. N., Sexuality in Ancient India: A Study Based on the Pali Vinayapitaka. Postgraduate Institute of Pali and Buddhist Studies, University of Kelaniya, Sri Lanka, 1993.

Piatigorsky, A., The Buddhist Philosophy of Thought: Essays in Interpretation. Curzon Press, London, 1984.

Pindar, The Odes of Pindar. Bowra, C. M. (Trans.), Penguin Classics, London, 1969.

Plato, The Symposium. Hamilton, W. (Trans.), Penguin, London, 1951.

Plato, The Republic. Lee, D. (Trans.), Penguin, London, 1987.

Potter, K. (Ed.), Abhidhamma Buddhism to 150AD. Encyclopaedia of Indian Philosophies, Vol. VII, Motilal Banarsidass Publishers, Delhi, 1996.

Propertius, The Poems of Propertius. Musker, R. (Trans.), J M Dent \& Sons, London, 1972.

Radhakrishnan, S. (Trans.), The Principal Upanișads, Unwin, London, 1969.

Rijken van Olst, B., 'Right Views or No Views?' http://www.theosophy-nw.org/theosnw/ world/asia/rel-bas.htm. Reprinted from Sunrise Magazine, Theosophical University Press, February/March 1990 [accessed 5/12/01].

Rosan, L. J., 'Desirelessness and the Good.' In Philosophy East \& West, Vol. 5, 1955, pp. 57-60. http://pears2.lib.ohio-state.edu/FULLTEXT/JR-PHIL/ew27149.htm [accessed 01/05/2002].

Rowlands, M. (Ed.), Abhidhamma Papers. Samatha Trust, UK, HTML Edition, 1998. http://www.samatha.demon.co.uk/publications/abhidhammapapers [accessed 16/07/02].

Ryle, G., The Concept of Mind. Penguin, London, 1963.

Sadakata, A., Buddhist Cosmology: Philosophy and Origins. Kōsei Publishing Company, Tokyo, 1997.

Sartre, J.-P., Being and Nothingness. Routledge. London, 1969.

Sartre, J.-P., Outline of a Theory of the Emotions. Citadel Press, New York, 1976.

Scharfstien, B.-A., A Comparative History of World Philosophy. State University of New York Press, New York, 1998.

Schmidt, M. (Ed.), Eleven British Poets. Methuen, Cambridge, 1980.

Schopenhauer, A., The World as Will and Representation, two volumes. Dover Publication, New York, 1969.

Schrift, A. D., 'Spinoza, Nietzsche, Deleuze: An Other Discourse of Desire.' In Continental Philosophy: Philosophy \& Desire, Vol. VII, Routledge, 2000.

Schueler, G. F., Desire: Its Role in Practical Reason and the Explanation of Action. Massachusetts Institute of Technology (MIT) Press, Massachusetts, 1995.

Schumann, H. W., The Historical Buddha. Arkana, London, 1989.

Shakespeare, The Alexander Text of William Shakespeare: The Complete Works. Collins, UK, 1951.

Sharma, A., A Jaina Perspective on the Philosophy of Religion. Motilal Banarsidass, Delhi, 2001.

Shende, H. J., The Religion and Philosophy of the Atharvaveda. Bhandakar Oriental Research Institute, Poona, 1952. 


\section{BIBLIOGRAPHY}

Siegel, L., Sacred and Profane Dimensions of Love in Indian Traditions as Exemplified in the Gĩtagovinda of Jayadeva. Oxford University Press, Delhi, 1978.

Skilton, A., A Concise History of Buddhism. Windhorse Publications, Birmingham, 1997.

Snelling, J., The Buddhist Handbook: A Complete Guide to Buddhist Teaching and Practice. Century Hutchinson, London, 1987.

Sødring, C., Hamlet beyond death. Unpublished conference paper. Presented at 'Desire: Eighth International Philosophy Graduate Conference', University of Essex, 28th June, 2002.

Solomon, R. C., Continental Philosophy Since 1750. Oxford University Press, Oxford, 1988.

Sophocles, The Three Theban Plays: Antigone, Oedipus, Oedipus at Colonus. Penguin, London, 1984.

Speake, J. (Ed.), A Dictionary of Philosophy. Pan Books Ltd, London, 1984.

Spinoza, B. de, On the Improvement of the Understanding; The Ethics; Correspondence. Dover Publications, New York, 1955.

Spiro, M., Buddhism and Society. Allen and Unwin, London, 1971.

Stevens, W., Selected Poems. Faber \& Faber, London, 1953.

Stevenson, L., Seven Theories of Human Nature. Oxford University Press, Oxford, 1974.

Stoeber, M., 'Dostoyevsky's Devil: The Will to Power.' In The Journal of Religion, Vol. 74, No. 1, January 1994, pp. 26-44.

Tamen, P., Honey and Poison: Selected Poems. Carcanet Press, Manchester, 2001.

Teichman, J., Evans, K., Philosophy: A Beginners Guide, Second Edition. Blackwell, Oxford, 1995.

Thanissaro, B., The Mind Like Fire Unbound. Dhamma Dana Publications, Barre, 1993.

Thich Nhat-Tu, B., Kusala and Akusala as Criteria of Buddhist Ethics. Downloaded from http://quangduc.com/English/kusala.htm. Buddhism Today (original publication) [accessed 13/01/01].

Titze, K., Jainism: A Pictorial Guide to the Religion of Non-Violence. Motilal Banarsidass, Delhi, 2001.

Trungpa, C., Glimpses of Abhidharma. Shambhala Publications, Boston, 2001.

Upadhyaya, S. C. (Trans.), Kama Sutra of Vatsyayana. Taraporevala Sons and Company, Bombay, 1963.

Valée Poussin, L. De La, Thomas, E. J. (Eds), Mahāniddesa. Pali Text Society, Oxford, 1978.

Vernant, J.-P., 'One . . Two . . Three: Erōs.' In D. Halperin et al. (Eds), Before Sexuality: The Construction of Erotic Experience in the Ancient Greek World. Princeton University Press, Princeton, 1990.

Visvader, J., 'Reply to Wayne Alt's "There is no paradox of desire in Buddhism".' In Philosophy East \& West, Vol. 30.4, 1980, pp. 531-2. http://pears2.lib.ohio-state.edu/ FULLTEXT/JR-PHIL/john2.htm [accessed 01/05/2002].

Warder, A. K., An Introduction to Pali. Pali Text Society, Oxford, 1995.

Warren, H., Jainism in Western Garb, as a Solution to Life's Great Problems (From Notes of Talks and Lectures by Virchand R. Gandhi). Crest Publishing House, New Delhi, 1993.

Watanabe, F., Philosophy and its Development in the Nikāyas and Abhidhamma. Motilal Banarsidass, Delhi, 1983.

Williams, Y., 'A Divine Life on Earth: Aurobindo's Interpretation of the Bhagavad-Gìtā.' In Williams, McElvaney (Ed.), Aurobindo and Zaehner on the Bhagavad-Gĩtā. Grevatt \& Grevatt, Newcastle upon Tyne, 1988. 
Wiltshire, M. G., Ascetic Figures Before and in Early Buddhism. Mouton de Gruyter, New York, 1990.

Winternitz, M., A History of Indian Literature, Vol. 1. Motilal Banarsidass, Delhi, 1981.

Winternitz, M., A History of Indian Literature, Vol. 2. Motilal Banarsidass, Delhi, 1983.

Wynne, A., 'An Interpretation of "Released on Both Sides" (Ubhato-bhāga-vimutti), and the Ramifications for the Study of Early Buddhism.' In Buddhist Studies Review, Vol. 19, No. 1, 2002, pp. 31-40.

Zaehner, R. C. (Trans.), Hindu Scriptures. J. M. Dent, London, 1966.

Zimmerman, M. E., 'Ontical Craving versus Ontological Desire.' In Babich, B. (Ed.), From Phenomenology to Thought, Errancy, and Desire. Kluwer Academic Publishers, Holland, 1995, pp. 501-23. 


\section{INDEX}

Note: Page numbers in bold indicate section headings.

Abhidhamma 8, 78, 95, 100, 103-4, 113, 115-17, 123, 130, 178, 191

Abhidhamma-pitaka 69

Abhidhamma Sangaha 115, 116

Abhidhammattha Sangaha 167, 174

Abhijjhā 111-12

Ācārāinga Sütra 83, 84

Advaita 75

Advaita-vedānta 69, 78, 195

Agastya 55, 57

Aggañ̃̃a Sutta 136, 137

aggi (fires) 100

Aggivacchagotta Sutta 171, 176

Aggregates, Buddhist notion of a person as 41

Akhmatova, A. 203

akusala 125, 130-5, 143-4, 166-8, 177, 184, 192, 200, 205

akusalamūla (the three roots of unskilful action) 100, 104

Alagaddūpama Sutta 97, 165

Ālāra Kālāma 98

Ait, W. 3, 208

amū views) 86

Ānanda 129, 135

anatta 11, 36, 47, 82, 91, 94, 96, 128, $133,140,156,195,197,201$

Anderson, C. 168, 176, 248

anicca (impermanent) 8, 28, 47, 128, 133 , 141, 156, 201

anicca, dukkha and anatta (three marks) 93

Anscombe, G. E. M. 6, 208

Anuruddha, Ācariya 115

Apekkhā 109-10

appanihita 107

Arahat 117, 162, 163, 186, 191, 192
Aristotle 24-5, 39, 46, 201, 212

Ariyapariyesanā Sutta (the Discourse on the Noble Quest) 93, 97, 126

Arjuna 71, 72, 74

Armstrong, J. 22, 26

arūpa 102, 186

arūpabhava 163

$\bar{A} s \bar{a}$ 110-11

$\bar{a} \operatorname{savās~(taints)~101;~cankers,~stains~}$ 167,168

āśrama 72, 76, 88

àtman $31,37,55,58,66,70,74,76-7$, 87-8, 90-1, 93, 96, 195-6;

àtman-brahman 32, 91; as

Brahman 68

Ațtakanāgara sutta 101

attavāda 167

atthakāmo (desiring the goal) 191

Atțhakavagga 170, 179

avidya $\bar{a}$ (S. spiritual ignorance) 69

avijjā (P. spiritual ignorance) 131, 137, $140,152,157,165-6,171,174,177$, 180-1, 185-6, 203-4

Avijjā Sutta 180; Avijjān̄ìvaranasuttam 180

Barrett, W. 195, 196

Bhagavad Gītā 49, 50, 65, 69-72; as offering a model of desireless action 73-6

Bhakta 73, 76-7; as wishing one-ness with God 78

Bhakti 69, 73, 76-7, 119, 195, 201

bhava-tanhā 151, 180

bhikkhu 98, 106, 113, 191, 199

Biardeau, M. 51, 52, 73, 74, 76, 77, 78

Blake, W. 20, 202, 212

Bodhi, Bhikku 116, 126, 166, 167, 176, 226, 239, 246 
Boisvert, M. 129, 131, 235

Brahman 31, 53, 62, 65, 67-8, 77, 87, 90-2, 94, 96, 196; as true nature of reality 56

Brahmanic traditions 1, 50

Brahmin 76, 182

Bṛad-āranyaka Upaniṣad 58, 60, 61, 62, $63,64,65$

Buddha, the 51, 81, 91, 110, 113, 115, 117-18, 127, 129, 132, 137, 182, 192, 194; attitude to 'views' of $166-8,171$, 176-8; as beyond contact with the world $92-3$; as flexible 238; life story of 97-8, 159; philosophical approach of 173,183

Buddhaghosa 8, 118, 148, 159, 175

Buddhism and desire 90

Burford, G. 95, 96, 169, 179, 224, 246, 248

Butler, J. 42-4, 188, 189, 251

cetasikas (mental factors) 102, 115, 116

Chachakkha Sutta 151

chanda 99, 108, 135, 192

Chāndogya Upanișad 59, 61, 62, 66, 67

Chapple, C. 59, 60, 62, 64

cittas 174, 177, 191

Collins, S. 122, 166, 172, 233, 247, 248

Cousins, L. 13, 155, 242

Cūlasīhanāda Sutta 167

Dasgupta, S. 81, 82

Deleuze, G. 19, 35, 36, 37, 41, 42, 45, 46, 188, 214

Desire and the Buddha 97; cosmic 204; and death 200; and disturbance:

paritassanā 119-20; dynamics of 143; as at the heart of the Bhagavad Gìta

70; as lack 21-3, 28-9, 36-7, 41-2, 47, 65-6, 96, 140, 188, 194-8; landscapes of 140-2; paradox of 2, 4, 86, 95; and power 203; redirection of 91; and the spiritual quest 122-7; varieties of 98 devas $57,64,68,92-4,163,195$

Dhamma 15, 92, 93, 113-14, 165, 183

Dhammachanda 115

Dhammapada 105, 154, 155

dhamma-vicaya 183, 184

dharma 71, 72-4, 76; as associated with Order 54

ditțhi (views) 107, 139, 166-9, 172, 177-82, 184-6, 191, 194; as 'direct seeing' 175, 176; ditthivisuddhi (purification of ditthi) 175; ditțhogo (wrong views) 167; Sammā-dițhi (right view) 108, 173-5, 178-9, 181, 186

Dollimore, J. 8, 22, 23, 25, 26, 28, 212 , 216, 238

Dosa (the inverse of desire) $100, \mathbf{1 0 2}$, 103-5, 131, 177, 236

Dostoyevsky, F. 37-9

dukkha 137, 140-1, 156-7, 159-60, 166, $173,180-1,185,193,200$; cessation of 133,193 ; as dis-ease 29,207 ; as dissatisfaction/spiritual ignorance 93, $156,166,185$; elimination of 37 ; importance of in Buddhist thought 97; as opposed to liberation 96,173 ; in pațicca-samuppāda 149-50

emptiness, as the driving force of desire 47 equanimity, Buddhist ideas of 84

Esanā 125-7; Esanā Sutta 126

Fires, the three (rāgaggi, dosaggi, mohaggi) 100

Freud(ian) model (concept) 19, 20, 21, $35,138,199,204$

Gethin, R. 114, 121-2, 124, 160, 169, $172,174,181,184,232-4,243$, 246-9, 253

Gombrich, R. 9, 171, 172, 173, 216, 238, 247

Goodheart, E. 38, 39, 215

van Gorkom, N. 112, 116

Gotama see Buddha, the

Govinda, Lama Anagarika 114, 152

Harvey, P. 105, 147, 148, 150, 153, 161, $162,164,223,224,229,239,241$, 242, 244,

Hegel, G. W. F. 34, 42, 43, 188-9

Heidegger's view 47, 48

Herman, A. L. 2, 4

Hevajra-tantra 132

Hindrances, Five 180, 184

Hobbes, T. 29, 212

Hume, D. 29, 30, 39, 189, 212, 213

iddhipādas (four bases of power) 114, 183

iddhis (great powers) 115

intention 5, 59

Itivuttaka 180 
Janavasabha Sutta 110, 114, 115, 184 jațā 128; Jața Sutta 129

Jayatilleke, K. N. 135, 136

jñana-yoga 77, 78

Johansson, R. E. A. 10, 134, 154, 155, 237, 242

Kālāma Sutta 182, 183

Kalupahana, D. 94, 147, 149, 160, 162, $165,177,178,183,223,239,243,245$, 248, 250

kāma 51, 53, 56-7, 70, 73, 87, 103, 186, 190-1, 200; kāma-loka 68, 106, 161; kāma-loka gods 94; kāmasukha (sense pleasure) 110 ; kāma-tanhhā 151; as sexual desire 79,80

Kāma and Chanda: common terms for desire 112-19, 124

Kāmadeva 56, 88

Kāma Sūtra 10, 76, 77, 79, 80, 88

kamma 121, 122, 198

Kant, I. 32, 198

karma (action) 63, 64, 82, 83, 84, 85; and rebirth 54

karmic consequences 14, 52

Kaṭha Upanișad 68

Keown, D. 13, 14, 119, 122, 208, 210 , 233, 236

khandhas 140, 158, 160

Killingley, D. 16, 53, 55, 59, 60, 65, 70-2, $75,86-7,217-21$

kiñcana (the three obstacles) 100

Krishna see Krsna

Krṣna 71, 72, 73, 74, 76, 77, 92, 195

kṣatriya 71

kusala (skilful) 1, 12-16, 96, 99-102, $108,112-16,125,127,130-5,141$, $143-4,167,173-5,177,179,184$, 191-2, 202, 205; kusala cittas 102; kusala-tanhā 136

Lash, Nicholas, Professor 49, 70, 71, 73 Lipner, J. 49, 50, 70

lobha 100, 102, 103-4, 109, 110, 117, 131,236

Locke, J. 29, 212,

loka 105, 106, 112

Maggasamyutta 126

Mahābhārata 52, 218

Mahācattārīsaka Sutta1 125, 174

Mahāhatthipadopama Sutta 146
Mahāparinibbāna Sutta 129, 168, 169

Mahāsaccaka Sutta 159

Mahāsāropama Sutta 185

Mahāsatipațthāna Sutta 108, 115, 123, 130, 151

Mahātaṇhāsankhaya Sutta 148, 166

Maitri Upanișad 65, 67, 76; see also Upanișads

mano (mind-organ) 152, 154-5, 163, 164

Māra (as embodying death and

kāma) 200

mārga (S. path) 77

Matthews, B. 16, 133-6, 139, 153-4, 199, $237,238,241,243$

māya $31,56,66,68,69,88,91$; as

illusion 56

mettā (loving kindness) 100, 109, 119

michā-ditthi 178

Milindapañha 158, 161

mind-body relationship 158-65

mindfulness $102,154,194$; of the body 160

moha 100, 102, 103-5, 131, 177, 236

Morrison, R. 16, 136-9, 180, 199, 236, 238

muñcitukamyatā (desire for freedom) 118

Mundaka Upaniṣad 68; see also Upanișads

Muni Sutta 183

Nāgasena 161, 162

nāma-rūpa (mind and body) 149-51, 158, $160-4$

Ñāṇamoli, Bhikku 176, 226, 239, 246

Ñānananda, Bhikku 175

nekkhamma (renunciation) 123, 124

Nettipakarana 132, 133, 134

Nhat-Tu Thich, Bhikku 13, 210

Nibbāna 12, 37, 58, 97, 91, 101-2, $120-4,127,133-5,139-41,144,149$, $156,159,162,166-8,175,184-5,196$; as attainable through faith in the Buddha 92; the Buddha's attainment of 97; desire for 3, 92, 94-6, 107, 109, $135,140,197$; as desireless 58,107 , 120, 124; as elimination of dukkha 37, $133,193,200,202$; as the ultimate goal 94, 109, 159, 166, 168, 184, 193, 196-7, 200, 202, 224; as unconditioned 95-6, 156

Nietzsche, F. 9, 15, 35-42, 73, 188-9, 194, 201, 204, 214-15, 224, 252, 253, 254 
nirāso (desireless) 191

nirodhatanhhā 133, 134

nișkāma-karma 72

Noble Eightfold Path 108, 126, 168

noble right view 178

Noble Truths 2, 37, 99, 130, 180

Olivelle, P. 67, 218

van Olst, Bas Rijken 172, 173

padhāna (striving) 98, 106, 107-9, 192; sammā-padhāna 113

\section{Panidhi 106}

Panihita 106-7

Panikkar, R. 21, 70

paribbājaka 97

parinibbāna (of the Buddha) 92, 93, 165

Patañjāli's Eight-Limbed Yoga system 78

Paticca-samuppāda (conditioned arising) 9, 46, 48, 88, 92, 111, 115, $131,148,150,163,165-6,172,177-8$, 180-1, 185-6, 193, 204; desire and $133,141,144-5,151-8$; the nature of $146-51$

Pațisambhidāmagga 118, 175, 180

Pattāna 164

'person', Buddhist concept of 163

Petakopadesa 169

petas (hungry ghosts) 157, 158, 163

phassa 152, 156

philosophy, 'Analytic' 9, 21

philosophy, 'Continental' 9

Philosophy East \& West 2, 16

Pipāsita 129

Plato 21-5, 28, 31, 38, 42, 72, 193, 212, 213

puthujjana (mere worldlings) 105, 144

rāga 99, 100, 102, 103, 105, 110, 177, 186; dhammarāga (passion for the

Dhamma) 101-2; as sexual passion 101

Rathavinīta Sutta 175,

reason, as contrasted with desire 46

religious devotion, as a longing for the divine 75

Republic, Plato's 24, 38

Rhys Davids, Mrs 98, 225

rūpa 102, 154, 160-4, 186

Sāmaññaphala Sutta 112

samkalpa (ritual intention) 54, 59, 60, 115
Sammā-ditți Sutta 153, 163, 168

sammā-saìkappa 108, 109, 125

Sampasādanīya Sutta 183

samsāra 88, 93, 118, 200

samvega (a sense of urgency-for-

liberation) 102, 103

Saṃyutta Nikāya 105, 126

sañcetana 183

Sangīti Sutta 125, 126, 129, 134

Sañīti Sutta 94, 167

Sankappa 122-5

Śankarācārya 64, 68, 69

sañkāras 119, 160

sañ̃̄ā 160

Sañ̃̄ānātts Sutta 113

sannyāsin $74,76,77,78$

sārāga 136

Sartre 37, 43, 44, 47, 58, 188-9, 193, 195-6, 214, 216

Śatapatha Brāhmana 53

Satipatthāna Sutta 159

Schopenhauer, A. 5, 20-1, 30-5, 39-40, $43,46,50,56,138,189-90,204$, 212-14

Schueler G. F. 5, 6, 7, 9, 21, 208, 209, 211

self, absence of in Buddhism 36; desire for 57,63

Seneca's view 23, 25, 47, 202, 217

Sevitabbāsevitabba Sutta 111

sex, love and desire: the Kāma Sütra

76, 80

sīla (virtue) 175

skilful means 139; see also kusala

Socrates 22, 23

Solomon, R. C. 20, 32, 34, 50, 212, 216

sotukāma (desire to hear) 118

de Spinoza, B. 29, 42, 212

śramana 81

Stevenson, L. 20, 203, 211

suffering, as arising from ignorance 37 ; see also dukkha

Sutta-Nipata 170, 172, 173, 179

Sutta-pitaka 69

svabhāva 96

Symposium (Plato's) 22, 23, 29, 42

Taittrīya Upanișad 62, 64

takka 194; see also ditthi

tanh $\bar{a}$ (craving and desire) 3, 32, 37, 46, $99,102,105,110,111,117$; as the basis of suffering $2,119,126, \mathbf{1 2 9 - 4 0}, 135$, 
137-40, 148-9, 151, 156-8, 163-5, 166, 180-1, 184, 191, 192, 193, 195, 197, 200, 203-4, 236

Taṇhā Sutta 180

Taṇhāsamyojanasuttam 180

tathāgata 92, 144, 176

Tattvārtha Sūtra 85

Thanissaro, B. 170, 171, 172

Udāna 191

upadāna 111, 149, 157,167, 168, 181, 185,

Upadhyaya, S. C. 80

Upanișads 34, 46, 50-2, 58, 59, 62, 65, $66,68-70,73,80,218,239 ; \bar{I}^{\prime} \dot{a} a$

Upanisad 69; Śvetāśvatara

Upanisad 67

utilitarianism 14, 15, 30

Vaccha (gotta) 176-8

Vacchagottasamyutta 178

Vātsyāyana 79, 80

Veda Samhitās 51, 59

vedanā 152, 156, 160, 163

Vedānta 32, 69
Vedas 10, 36, 53, 54, 64, 68, 70, 80, 157; Atharva Veda 56, 57, 217; Rg Veda 2, 53-6, 58, 60, 69-70, 80, $87-8,218$

Vibhañga 104, 105, 134, 155, 164

vibhava-tanhā 37,151

vīmamsā 183

Vinaya 165

viñ̃̃ānā 149, 150, 153, 160

virāga as absence of rāga 101

Visuddhimagga 99, 100, 118, 159, 175,233

Visvader, J. 3, 4, 208

Walshe, M. 126, 129, 167, 168, 183, 229, 231, 235

Warren, H. 4, 83

Will $31-4,37,43$; as a consequence of desire 5

Willing in Buddhism: adhitthāna and cetanā 120-22

yogin 68,77

Zimmerman, M. 48 